\title{
WestVirginiaUniversity
}

THE RESEARCH REPOSITORY @ WVU

Graduate Theses, Dissertations, and Problem Reports

2017

\section{Long-term Evaluation of Permanent Seeding and Mulching Practices}

Marissa A. Poultney

Follow this and additional works at: https://researchrepository.wvu.edu/etd

\section{Recommended Citation}

Poultney, Marissa A., "Long-term Evaluation of Permanent Seeding and Mulching Practices" (2017). Graduate Theses, Dissertations, and Problem Reports. 6442.

https://researchrepository.wvu.edu/etd/6442

This Thesis is protected by copyright and/or related rights. It has been brought to you by the The Research Repository @ WVU with permission from the rights-holder(s). You are free to use this Thesis in any way that is permitted by the copyright and related rights legislation that applies to your use. For other uses you must obtain permission from the rights-holder(s) directly, unless additional rights are indicated by a Creative Commons license in the record and/ or on the work itself. This Thesis has been accepted for inclusion in WVU Graduate Theses, Dissertations, and Problem Reports collection by an authorized administrator of The Research Repository @ WVU. For more information, please contact researchrepository@mail.wvu.edu. 


\section{Long-term Evaluation of Permanent Seeding and Mulching Practices}

\section{Marissa A. Poultney}

Thesis submitted to the

Benjamin M. Statler College of Engineering and Mineral Resources at West Virginia University

in Partial fulfillment of the requirements for the degree of

Master of Science in

Civil and Environmental Engineering

Leslie Hopkinson, Ph.D., Chair

Lance Lin, Ph.D.

John Quaranta, Ph.D.

Department of Civil and Environmental Engineering

Morgantown, West Virginia

2017

Keywords: hydrology, mulching, runoff, sedimentation, seeding

Copyright 2017 Marissa Poultney 


\section{Abstract \\ Long-term Evaluation of Permanent Seeding and Mulching Practices}

\section{Marissa A. Poultney}

Vegetation cover is required on disturbed land resulting from construction activities. The West Virginia Division of Highways (WVDOH) specifications for seeding and mulching currently includes seed mixtures that contain species that are considered highly invasive by the West Virginia Division of Natural Resources (WVDNR). This work evaluated the use of experimental seed mixtures at roadside locations by considering two major objectives: i) evaluating long-term performance of experimental mixtures over multiple growing seasons, and ii) investigating sediment yield from vegetation cover practice.

First, vegetation growth and persistence from four small-scale field plots were monitored through the second and third growing seasons. The first field plot compared vegetation resulting from current WVDOH seed mixtures to new native and low invasive experimental seed mixtures. The second field plot tested experimental seed mixtures and WVDOH mixtures at a high elevation location to determine success of an experimental high elevation mixture. The third field plot was prepared by varying seed bed preparation techniques: i) planting in existing soil using hydraulic erosion control product, ii) planting in existing soil using straw mulch, iii) planting in topsoil using hydraulic erosion control product, and iv) planting in topsoil using straw mulch. The final plot was prepared by varying soil amendments (e.g. planting in existing soil, topsoil, and two hydraulic growth mediums) and compared resulting vegetation of an experimental mowable areas mixture planted throughout the entire plot. All experimental mixtures, except experimental high elevation mixture, were found to perform as well or better than current WVDOH seed mixtures. There was no significant difference between seed bed preparation with respect to resulting ground cover or biomass. Soil amendments were found to be comparable alternatives to topsoil and are being recommended to WVDOH specifications.

Second, runoff collection devices were constructed and deployed at one subplot of each of the four varying seed bed preparations. The traps collected runoff from storm events, and the runoff was analyzed for nutrients and sediment yield. Field-measured sediment yield was compared to estimated sediment yield that was calculated using the Modified Universal Soil Loss Equation (MUSLE). Limitations of the study did not allow accurate comparisons between the MUSLE and actual sediment yield. However, lack of runoff during one storm event proved that vegetation from all seed bed preparations completely prevents runoff from small storm events $(\leq 0.5$ in $(1.27 \mathrm{~cm})$ ). Future work should include monitoring of experimental mixtures over further growing seasons. 


\section{Acknowledgements}

This work would not have been possible without the support of many people in my life. I would like to thank my research advisor, Dr. Leslie Hopkinson, for her continued help and dedication throughout this entire project. She has helped me advance as a civil engineer and a professional. I am grateful for the guidance from my entire committee that includes my research advisor, Dr. John Quaranta, and Dr. Lance Lin.

I would also like to thank Donald Williams, Charlie Riling, and Michael Pumphrey from the West Virginia Division of Highways for their efforts to help make this project successful. Their input and comments helped guide me throughout the entire project. I also want to thank Lauren Alaniz from ECB Verdyol for her support and help throughout the project.

I would like to acknowledge the hard work of my fellow researchers, Forrest Pritt, Katelyn Kosar, and Matt Hudson, that helped through grueling days in the field and long days in the office. I could not have completed this without them. 


\section{Grant Information}

The contents of this report reflect the views of the author who is responsible for the facts and the accuracy of the data presented herein. The contents do not necessarily reflect the official views or policies of the State. This report does not constitute a standard, specification, or regulation. Trade or manufacturers' names which may appear herein are cited only because they are considered essential to the objectives of this report. The State of West Virginia does not endorse products or manufacturers. Prepared for the West Virginia Department of Transportation Division of Highways. 


\section{Table of Contents}

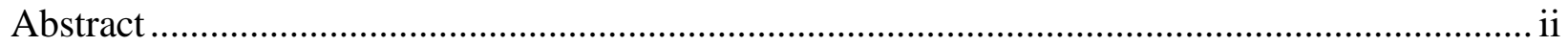

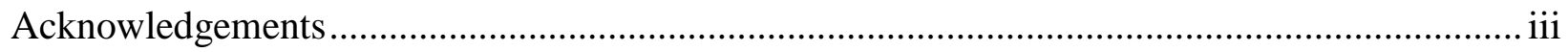

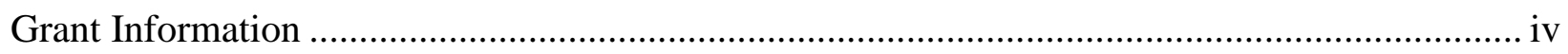

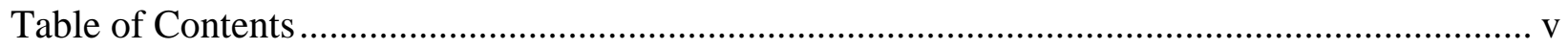

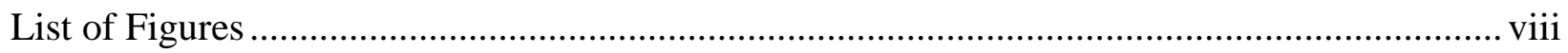

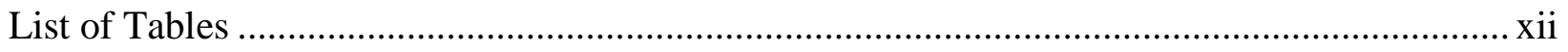

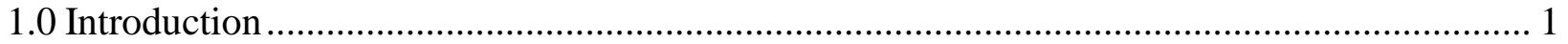

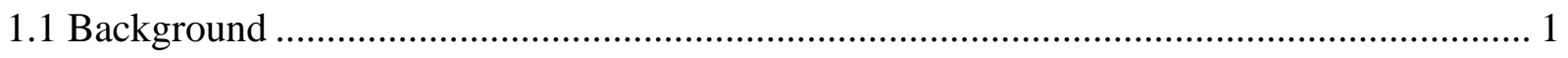

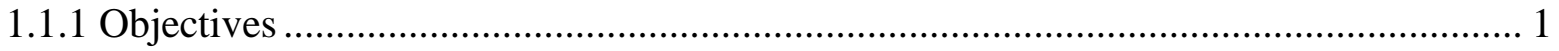

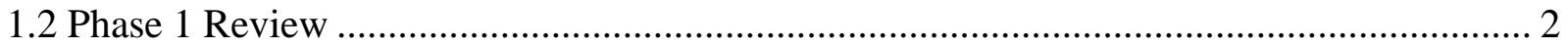

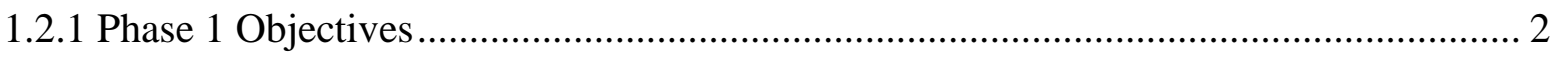

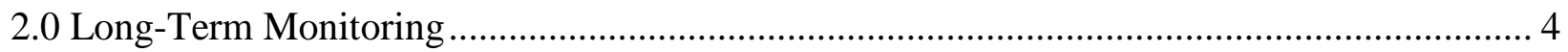

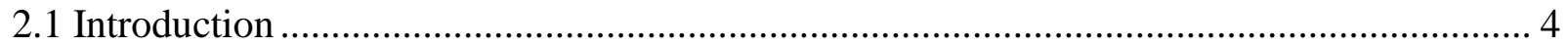

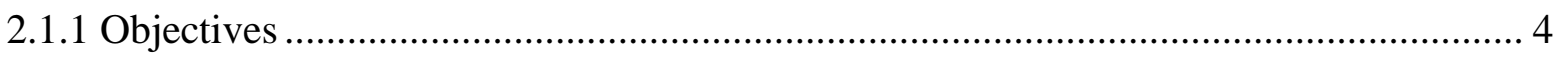

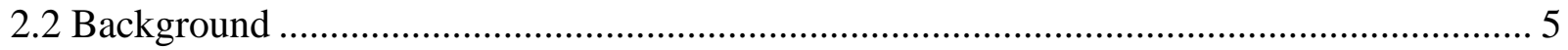

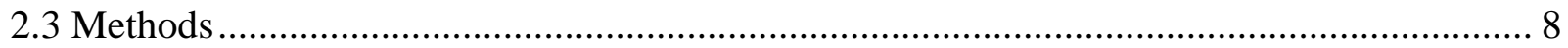

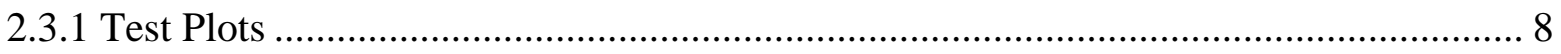

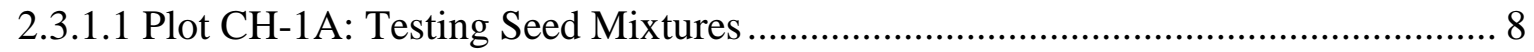

2.3.1.2 Plot CH-2: Testing Experimental High Elevation Seed Mixture.......................... 9

2.3.1.3 Plot CH-3: Testing Seed Bed Preparation Techniques .................................... 10

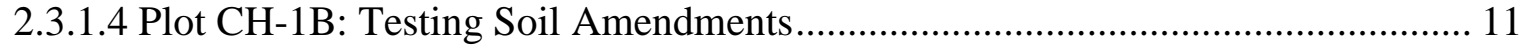

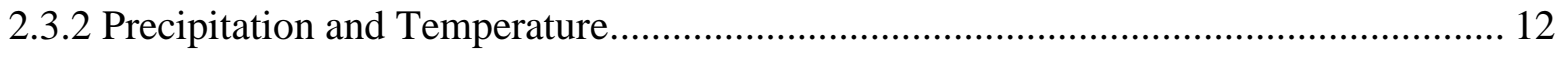

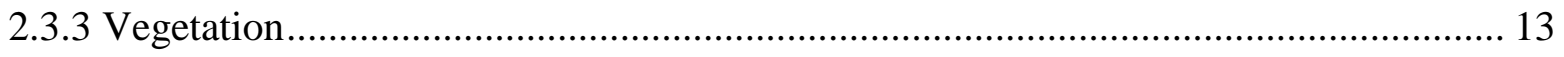

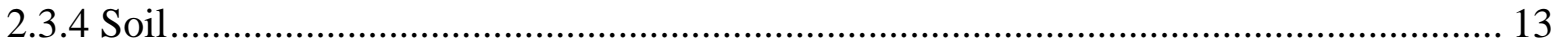

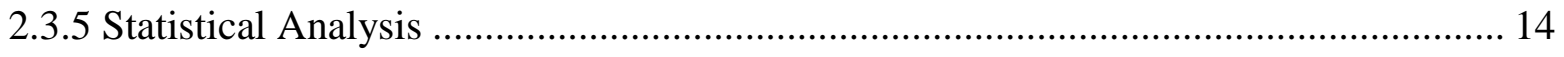

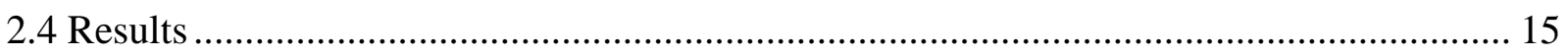

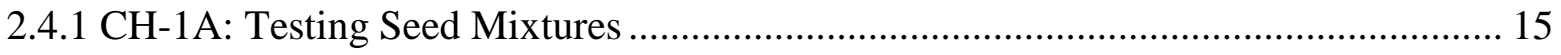

2.4.1.1 Temperature and Precipitation ................................................................... 15

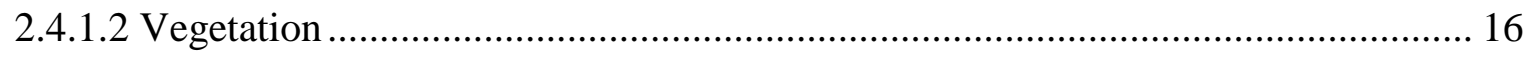




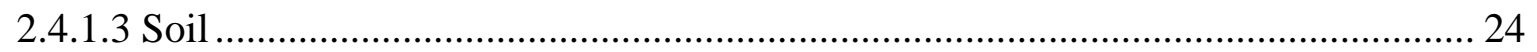

2.4.2 CH-2: Testing Experimental High Elevation Seed Mixture......................................... 24

2.4.2.1 Temperature and Precipitation ........................................................................... 24

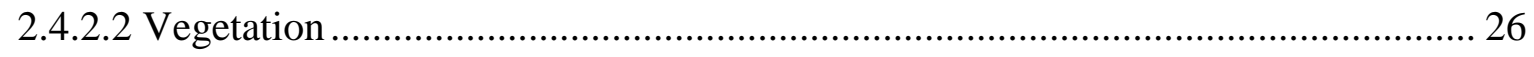

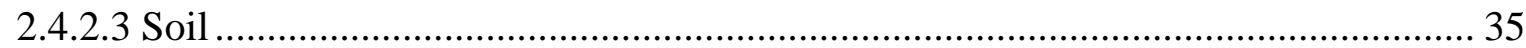

2.4.3 CH-3: Testing Seed Bed Preparation Techniques ………………………………....... 35

2.4.3.1 Temperature and Precipitation .............................................................................. 35

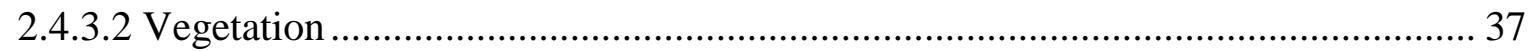

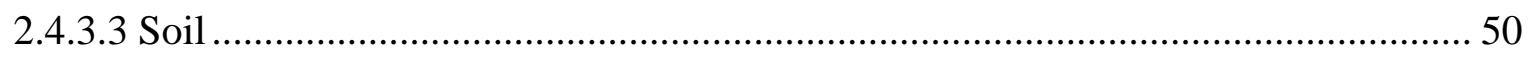

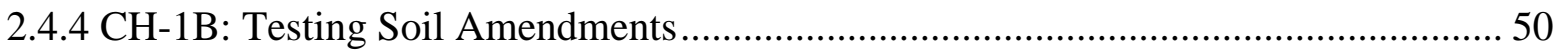

2.4.4.1 Temperature and Precipitation ......................................................................... 50

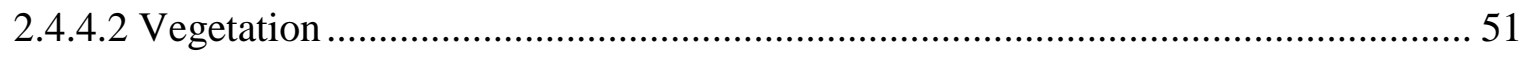

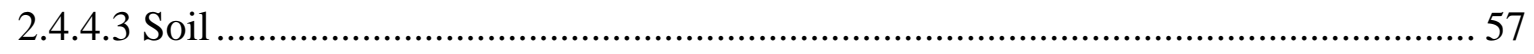

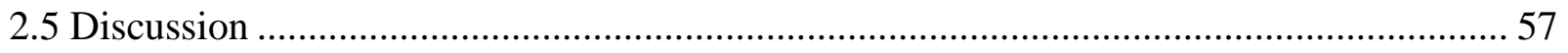

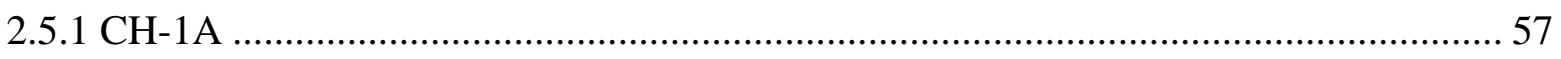

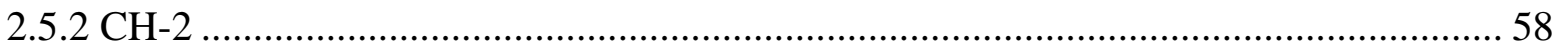

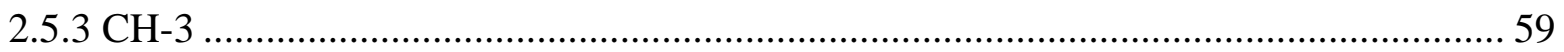

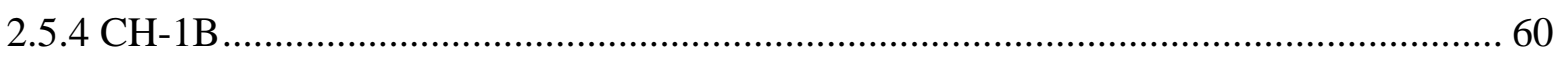

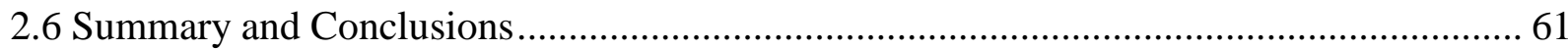

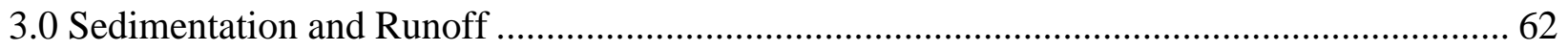

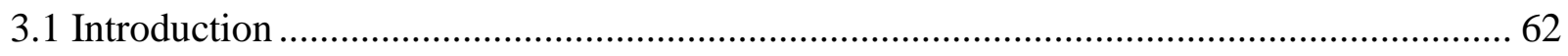

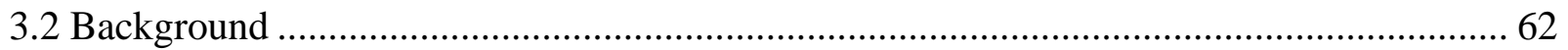

3.2.1 Sedimentation and Runoff Test Plots ...................................................................... 62

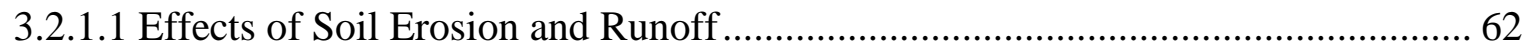

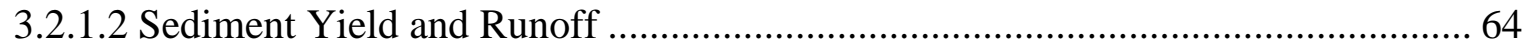

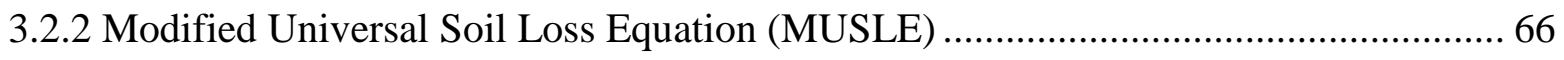

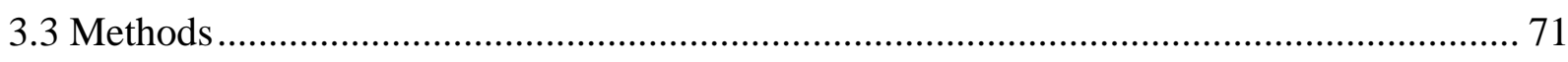

3.3.1 Sediment and Runoff Subplot Selection.................................................................... 71

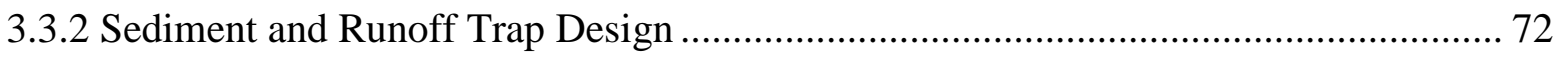

3.3.3 Sedimentation and Runoff Trap Installation ........................................................... 77

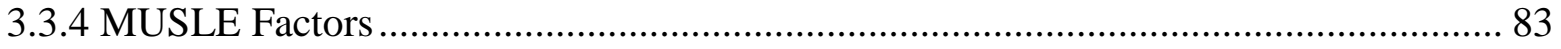




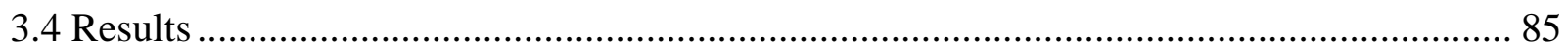

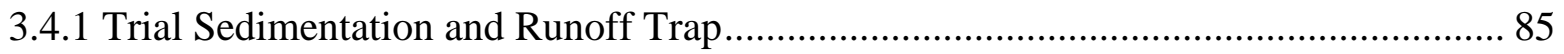

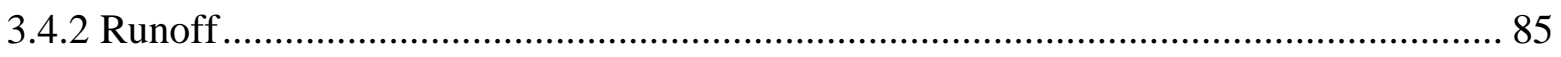

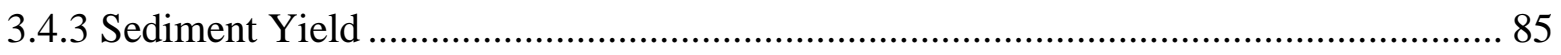

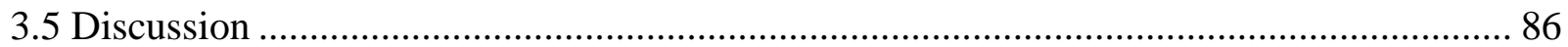

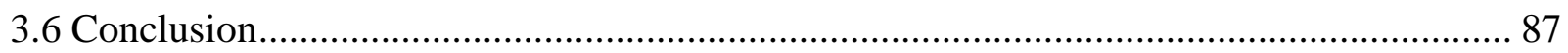

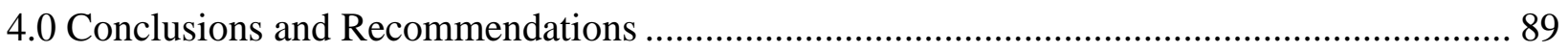

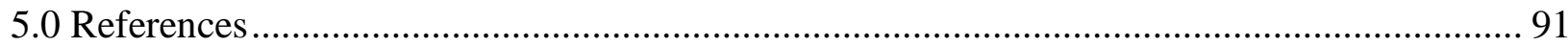

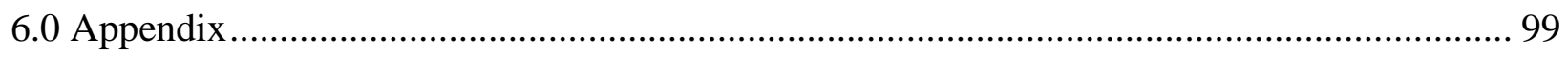

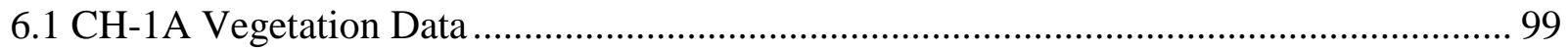

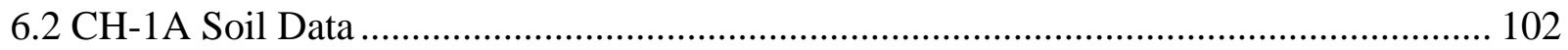

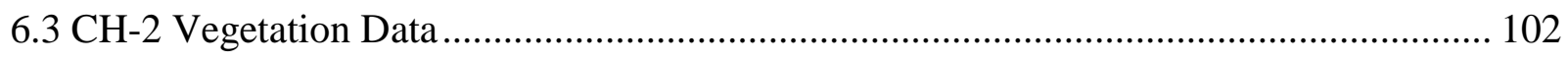

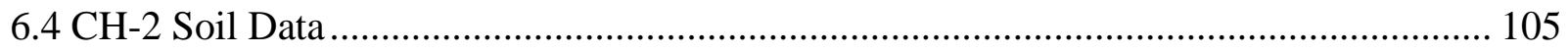

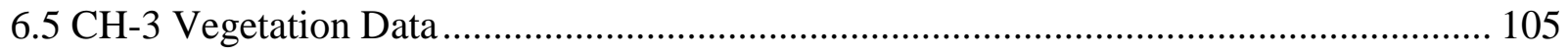

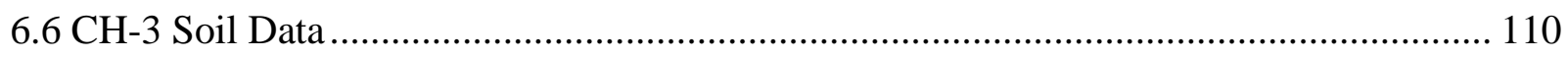

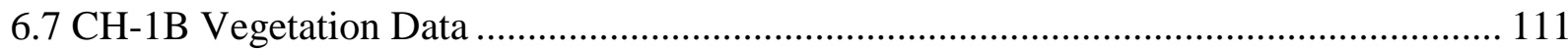

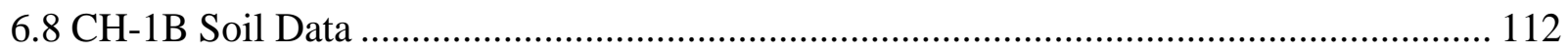




\section{List of Figures}

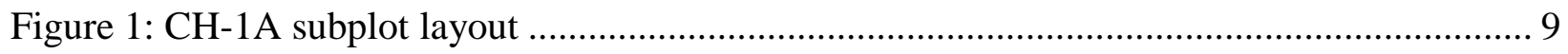

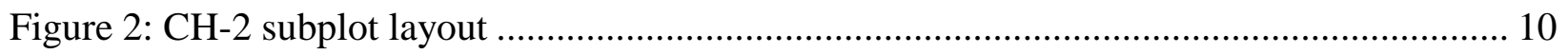

Figure 3: CH-3 subplot layout $(\mathrm{TS}=$ topsoil; NTS=no Topsoil; $\mathrm{S}=$ straw Mulch; HP=hydraulic

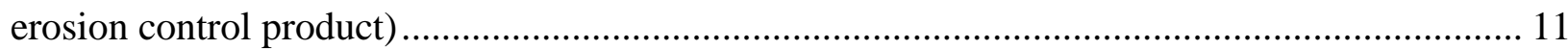

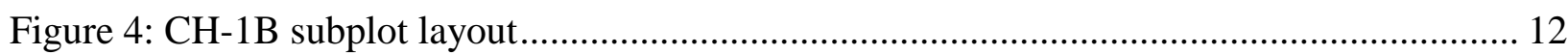

Figure 5: $\mathrm{CH}-1 \mathrm{~A}$ distribution of air temperature and precipitation for the second growing season (June-October 2016) .................................................................................................... 15

Figure 6: $\mathrm{CH}-1 \mathrm{~A}$ distribution of air temperature and precipitation for the third growing season (June-July 2017) ................................................................................................................ 16

Figure 7: CH-1A second growing season average ground cover (2016) ................................... 17

Figure 8: CH-1A distribution of ground cover for seed mixtures: cool season, DOH cut/fill, DOH medians, high elevation, mowable areas, and warm season; median (-); 25-75\% (box); min and max (whisker); $10 \%$ (-) (2016) ................................................................................... 17

Figure 9: CH-1A average ground cover by species (October 2016) ...................................... 18

Figure 10: CH-1A total biomass weight (October 2016) ..................................................... 20

Figure 11: CH-1A distribution of biomass for six seed mixtures: cool season, DOH cut/fill, DOH medians, high elevation, mowable areas, and warm season (2016) ........................................ 20

Figure 12: CH-1A third growing season average ground cover $(2017)$.................................... 21

Figure 13: CH-1A distribution of ground cover for seed mixtures: cool season, DOH cut/fill, DOH medians, high elevation, mowable areas, and warm season; median (-); 25-75\% (box);

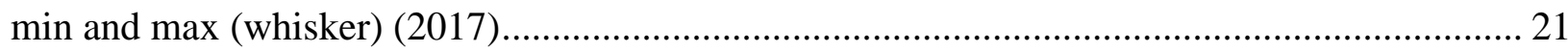

Figure 14: CH-1A average ground cover by species (August 2017) ........................................ 22

Figure 15: CH-1A total biomass weight (July 2017)........................................................ 23

Figure 16: CH-1A distribution of biomass for six seed mixtures: cool season, DOH cut/fill, DOH medians, high elevation, mowable areas, and warm season (2017) ...................................... 23

Figure 17: $\mathrm{CH}-2$ distribution of air temperature and precipitation for the second growing season (June-October 2016) ........................................................................................... 25

Figure 18: $\mathrm{CH}-2$ distribution of air temperature and precipitation for the third growing season (June-July 2017) .............................................................................................................. 26

Figure 19: CH-2 second growing season average percent ground cover (2016) ....................... 27 Figure 20: CH-2 distribution of ground cover for five seed mixtures: cool season, DOH medians, high elevation, mowable areas, and warm season; median (-); 25-75\% (box); min and max

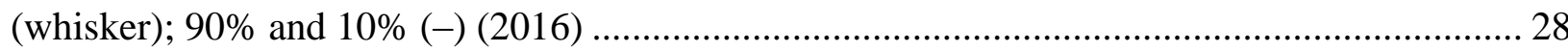

Figure 21: CH-2 average ground cover by species (October 2016) .......................................... 29

Figure 22: CH-2 total biomass weight (October 2016) ...................................................... 31

Figure 23: $\mathrm{CH}-2$ distribution of biomass for five seed mixtures: cool season, DOH medians, high elevation, mowable areas, and warm season (2016) ...................................................... 31

Figure 24: CH-2 third growing season average percent ground cover (2017) ......................... 32 
Figure 25: CH-2 distribution of ground cover for five seed mixtures: cool season, DOH medians, high elevation, mowable areas, and warm season; median (-); 25-75\% (box); min and max

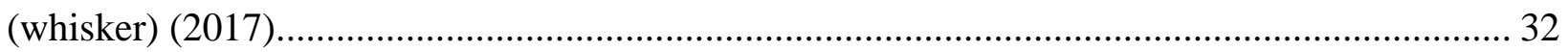

Figure 26: CH-2 average ground cover by species (August 2017) ...................................... 33

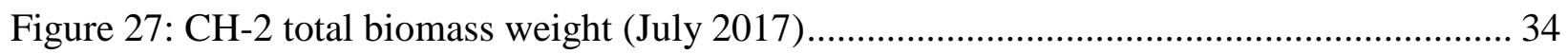

Figure 28: CH-2 distribution of biomass for five seed mixtures: cool season, DOH medians, high elevation, mowable areas, and warm season (2017) ........................................................ 35

Figure 29: $\mathrm{CH}-3$ distribution of air temperature and precipitation for the second growing season

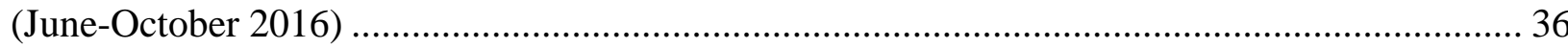

Figure 30: CH-3 distribution of air temperature and precipitation for the third growing season

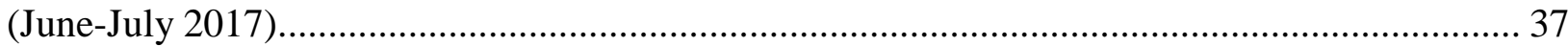

Figure 31: CH-3 second growing season average percent ground cover; error bars denote

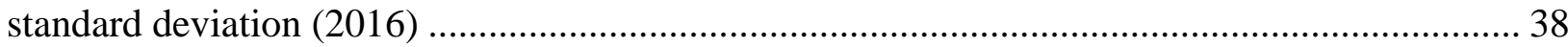

Figure 32: $\mathrm{CH}-3$ second growing season average percent ground cover by seed mixture (2016) 39

Figure 33: CH-3 second growing season average percent ground cover by mulch (2016) ......... 39

Figure 34: CH-3 second growing season average percent ground cover by soil (2016) ............. 40

Figure 35: CH-3 distribution of ground cover for four seed bed treatments: no topsoil with

HECP, no topsoil with straw mulch, topsoil with HECP, and topsoil with straw mulch; median (-); 25-75\% (box); min and max (whisker); $90 \%$ and 10\% (-) (2016)

Figure 36: CH-3 distribution of ground cover for three seed mixtures: cool season, DOH Medians, and warm season; median (-); 25-75\% (box); min and max (whisker); 90\% and 10\%

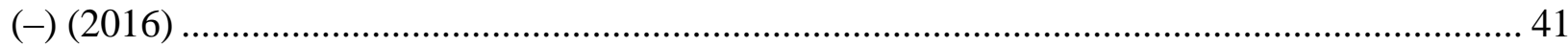

Figure 37: CH-3 average ground cover by species (October 2016) ........................................ 42

Figure 38: CH-3 total biomass weight (October 2016) ........................................................ 43

Figure 39: CH-3 distribution of biomass for four seed bed treatments: no topsoil with HECP, no topsoil with straw mulch, topsoil with HECP, and topsoil with straw mulch (2016) ................ 43 Figure 40: CH-3 distribution of biomass for three seed mixtures: cool season, DOH Medians, and

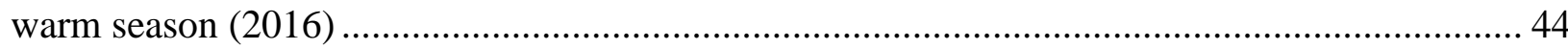

Figure 41: CH-3 third growing season average percent ground cover; error bars denote standard

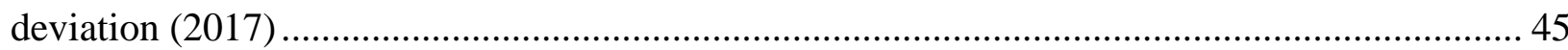

Figure 42: $\mathrm{CH}-3$ third growing season average percent ground cover by seed mixture (2017) ... 45

Figure 43: CH-3 third growing season average percent ground cover by mulch (2017) ............ 46

Figure 44: CH-3 third growing season average percent ground cover by soil (2017)............... 46

Figure 45: $\mathrm{CH}-3$ distribution of ground cover for four seed bed treatments: no topsoil with HECP, no topsoil with straw mulch, topsoil with HECP, and topsoil with straw mulch; median $(-) ; 25-75 \%$ (box); $\min$ and $\max$ (whisker); $90 \%$ and $10 \%(-)(2017)$.................................. 47

Figure 46: CH-3 distribution of ground cover for three seed mixtures: cool season, DOH Medians, and warm season; median (-); 25-75\% (box); min and max (whisker); 90\% and 10\%

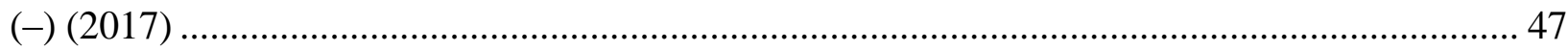

Figure 47: CH-3 average ground cover by species (August 2017) ...................................... 48 
Figure 48: CH-3 total biomass weight (July 2017).

Figure 49: CH-3 distribution of biomass for four seed bed treatments: no topsoil with HECP, no topsoil with straw mulch, topsoil with HECP, and topsoil with straw mulch (2017) 49

Figure 50: CH-3 distribution of biomass for three seed mixtures: cool season, DOH Medians, and

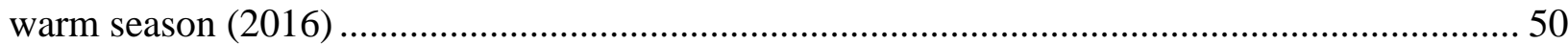

Figure 51: CH-1B second growing season average percent ground cover (2016) ..................... 51

Figure 52: $\mathrm{CH}-1 \mathrm{~B}$ distribution of ground cover for four treatments: Biotic Earth, no topsoil, ProGanics, and topsoil; median (-); 25-75\% (box); min and max (whisker); $90 \%$ and 10\% (-)

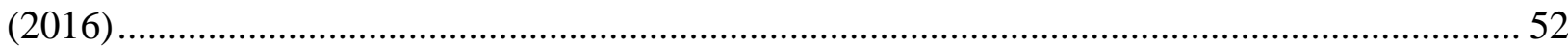

Figure 53: CH-1B average ground cover by species (October 2016) ..................................... 53

Figure 54: CH-1B total biomass weight (October 2016) ................................................ 53

Figure 55: CH-1B distribution of biomass for four treatments: Biotic Earth, no topsoil, ProGanics, and topsoil; median (-); 25-75\% (box) (2016)............................................... 54

Figure 56: CH-1B third growing season average percent ground cover (2017)........................ 54

Figure 57: $\mathrm{CH}-1 \mathrm{~B}$ distribution of ground cover for four treatments: Biotic Earth, no topsoil, ProGanics, and topsoil; median (-); 25-75\% (box); min and max (whisker) (2017) ............... 55

Figure 58: CH-1B average ground cover by species (August 2017) ...................................... 55

Figure 59: CH-1B total biomass weight (July 2017) .......................................................... 56

Figure 60: CH-1B distribution of biomass for four treatments: Biotic Earth, no topsoil, ProGanics, and topsoil; median (-); 25-75\% (box); letters denote statistical similarity (2017). 56 Figure $61 \mathrm{CH}-3$ sedimentation and runoff trap subplot locations......................................... 72 Figure 62: Pre-construction of sedimentation/runoff collection troughs in lab ........................ 72 Figure 63: CH-3 WVDOH type B (TS, HP, 1) and WVDOH type B (TS, S, 2) sedimentation and runoff subplot collection apparatus 74

Figure 64: CH-3 WVDOH type B (NTS, HP, 1) sedimentation and runoff subplot collection

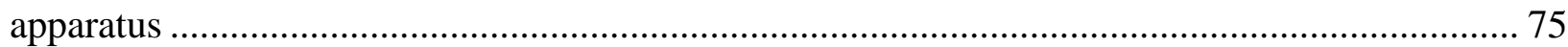

Figure 65: CH-3 WVDOH type B (NTS, S, 2) sedimentation and runoff subplot collection

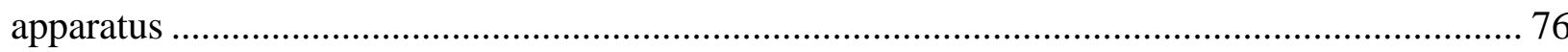

Figure 66: Runoff and sedimentation storage containers with volume labels ........................... 76

Figure 67: Installation of test sedimentation and runoff collection gutter................................ 78

Figure 68: All angle views of trial sedimentation and runoff apparatus................................. 80

Figure 69: CH-3 WVDOH type B (NTS, HP, 1) and (TS, HP, 1) front view of sedimentation

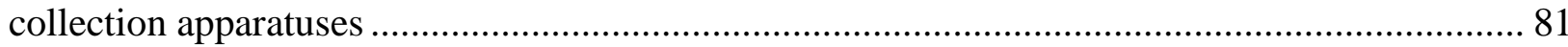

Figure 70: CH-3 WVDOH type B (TS, HP, 1) collection gutter and storage container with rolled wire reinforcement 82

Figure 71: CH-3 WVDOH type B (NTS, S, 2) and (TS, S, 2) left view of sedimentation collection apparatuses 82

Figure 72: CH-3 WVDOH type B (NTS, S, 2) sediment and runoff collection apparatus ......... 83

Figure 73: CH-3 WVDOH type B (TS, S, 2) sediment and runoff collection apparatus ............ 83

Figure 74: CH-1 cumulative degree days (2016) ............................................................ 99 


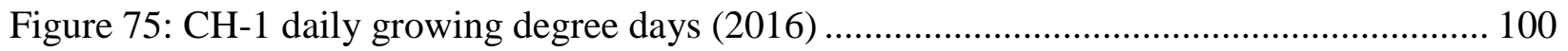

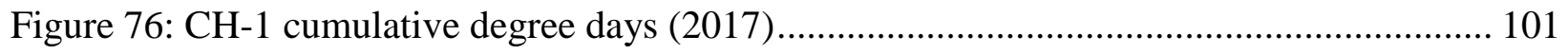

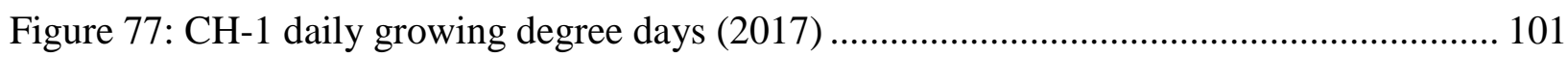

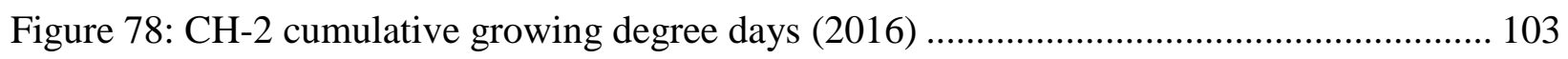

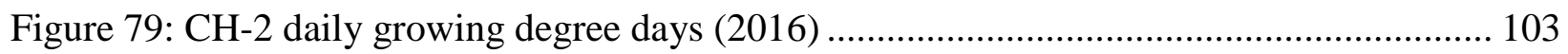

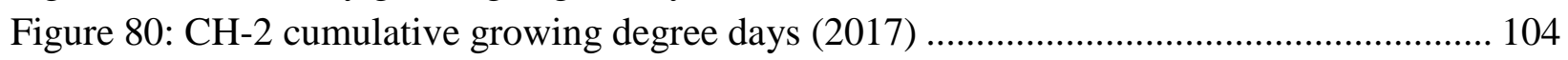

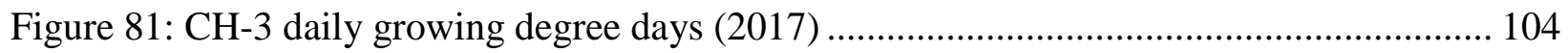

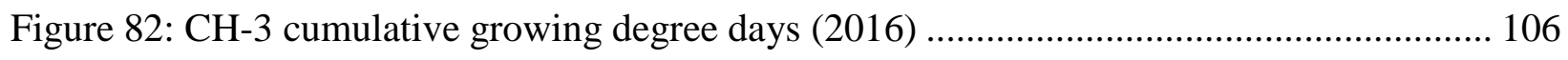

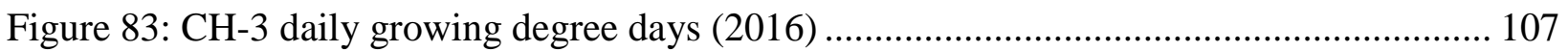

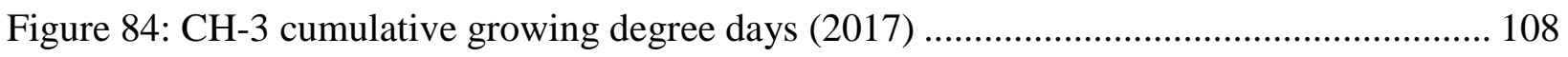

Figure 85: CH-3 daily growing degree days (2017) ……...................................................... 109 


\section{List of Tables}

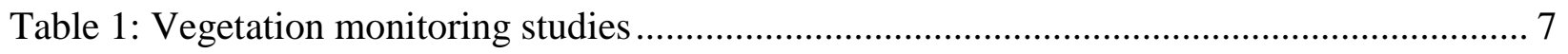

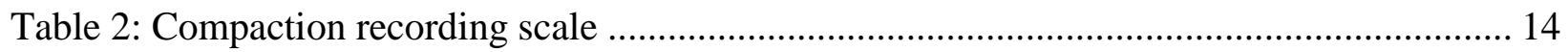

Table 3: CH-1A average ground cover by area (October 2016) ............................................ 19

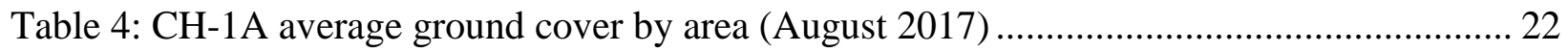

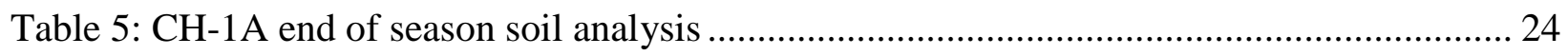

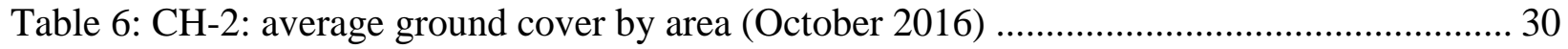

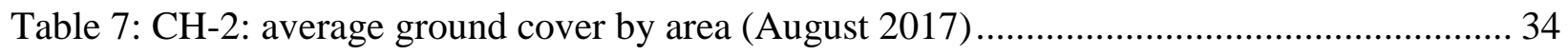

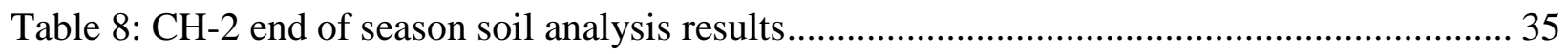

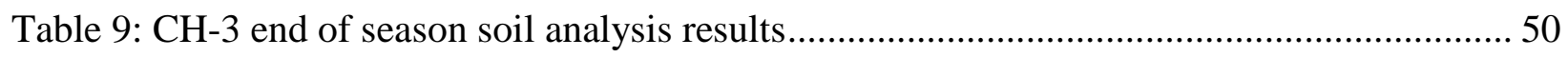

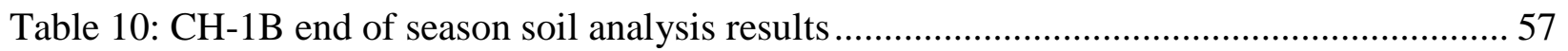

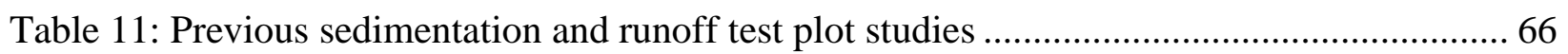

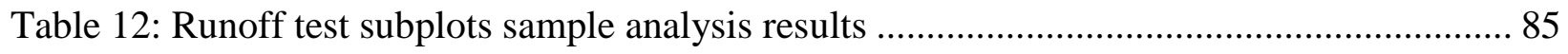

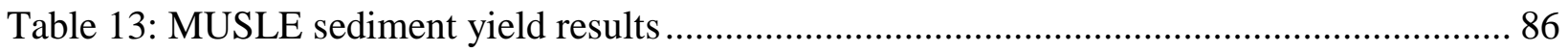

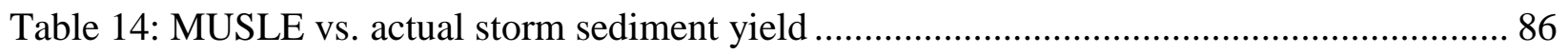

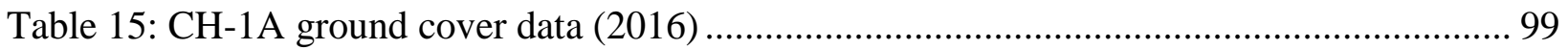

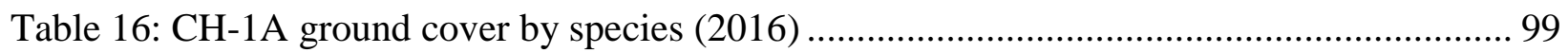

Table 17: CH-1A ground cover data (2017) ......................................................................... 100

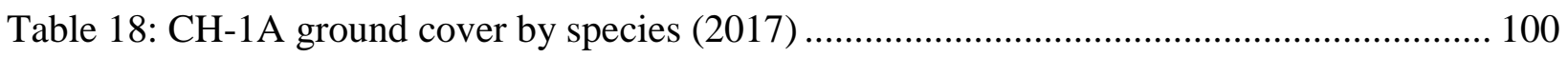

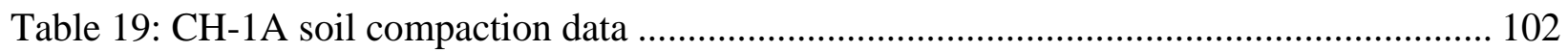

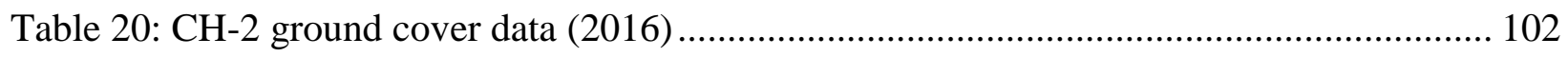

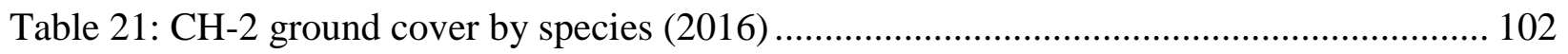

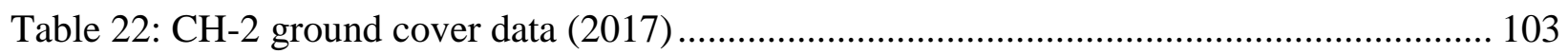

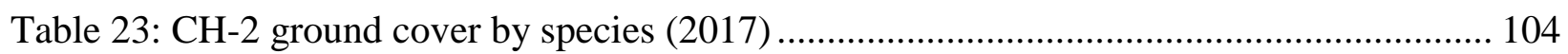

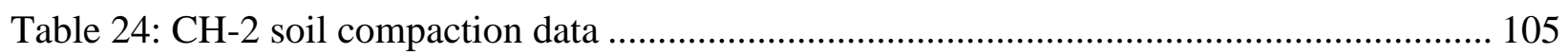

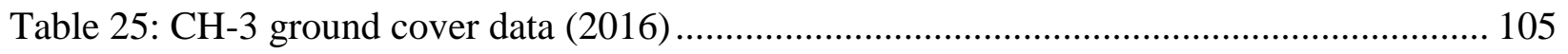

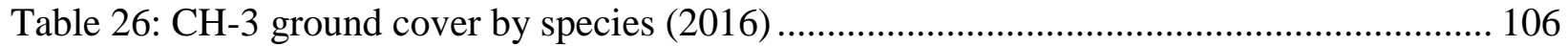

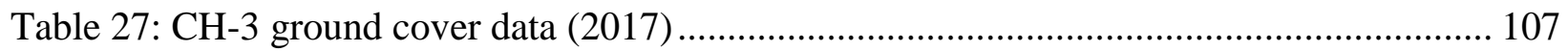

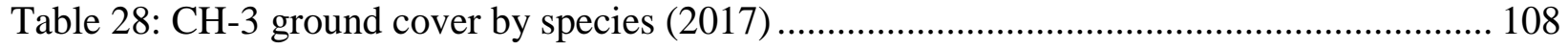

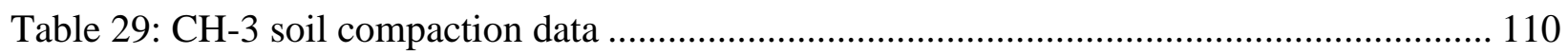

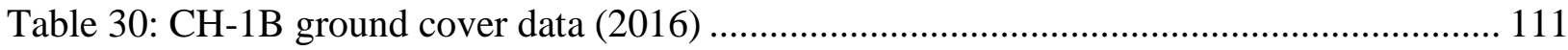

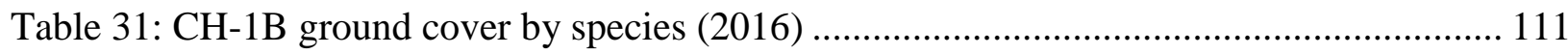

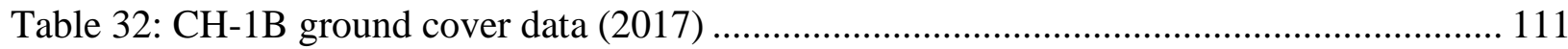

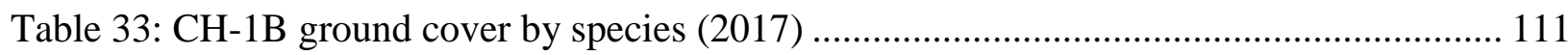

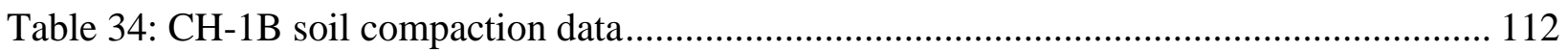




\subsection{Introduction}

\subsection{Background}

Seeding is the most practicable option for erosion control on a site that has undergone construction. Seeding plans are required by the National Pollutant Discharge Elimination System (NPDES) Permit when an area of land 1 ac (0.405 ha) or greater is disturbed. Plans should include site specific temporary and permanent seeding and mulching, as well as any other erosion control means (Division of Water and Waste Management 2012). Vegetation stabilizes slopes by slowing runoff, increasing infiltration, and creating root structures to strengthen the hillside (Yang et al. 2016).

After construction, the ground becomes disturbed by soil compaction and loss of existing vegetation. Compacting soil limits infiltration and plant rooting. These factors lead to increased surface runoff and erosion (Muckel 2004). Seed bed preparation, seed mixtures, and soil amendments affect the resulting vegetation establishment. Results from each of these factors can vary based on location. Therefore, revegetation techniques should be location specific.

Techniques should be established based on experimental results in the area that is expected to be revegetated (Montalvo et al. 2002).

In the past few decades, the importance of using native seed mixtures for revegetation has been recognized (e.g. Skousen and Venalbe 2008; Rentch et al. 2005; Tikka et al. 2000). Skousen and Venable (2008) and Rentch et al. (2005) studied the importance of establishing and protecting native vegetation along West Virginia roadways to prevent invasive species from spreading across the state. Seeding construction sites with native vegetation must be accompanied with vegetation management over time to ensure that native species establish and are not overtaken by invasive species (Skousen and Venable 2008; Blossey 1999).

Invasive species are often used to seed disturbed land because of their abundance and low cost. However, invasive vegetation poses threats to local environments and ecology. With more plant and animal species becoming endangered and extinct, it is important to make efforts to protect the environment (Montalvo et al. 2002; Skousen and Venable 2008).

\subsubsection{Objectives}

Experimental seed mixtures, some of which contain native species, were developed for right-ofway locations by Hilvers (2015). These new mixtures were previously tested for short-term establishment over one growing season. This work expands that previous work to test four experimental seed mixtures over multiple growing seasons. Both vegetation establishment and erosion protection were considered. Specific objectives include the following:

1. Evaluate the long-term performance of experimental seed mixtures over multiple growing seasons 
- Compare results of experimental native and introduced seed mixtures to current WVDOH seed mixtures

- Assess the performance of experimental high elevation seed mixtures

- Test the use of different seed bed preparation techniques on resulting vegetation

- Evaluate the success of using different soil amendments during planting

2. Calculate sediment and runoff produced from disturbed land with vegetation planted in different seed bed preparation techniques

\subsection{Phase 1 Review}

This research is part of the second phase of research project RP-293 funded by the West Virginia Division of Highways (WVDOH). The intent of the entire research project was to investigate and make recommendations to update the current WVDOH Specification "Section 652 Seeding and Mulching" (WVDOH 2010a). This specification outlines the requirements for seeding and mulching post-construction. Specification Section 652 complies with National Pollution Discharge Elimination (NPDES) permit that requires 70\% vegetation coverage by the West Virginia Department of Environmental Protection (WVDEP) on all construction sites greater than 1 ac (0.405 ha). Sites ranging from 1-3 ac (0.405-1.21 ha) must comply with the Notice of Intent (NOI) NPDES permit. All sites greater than 3 ac (1.21 ha) must meet the terms of the full NPDES Water Pollution Control Permit. There is not currently a requirement for specific vegetation ground cover on construction sites less than one acre $(0.405 \mathrm{ha})$.

In the first phase of RP-293, small-scale plots were constructed to test experimental seed mixtures that were created to replace invasive species (Hilvers 2015, Hilvers et al. 2017). Tested seed mixture categories created include:

- WVDOH Type B: Mowable Areas (WVDOH Medians)

- WVDOH Type D: Cut/Fill

- Experimental Type A: Mowable Areas

- Experimental Type B: Warm Season

- Experimental Type C: Cool Season

- Experimental Type D: High Elevation

- Experimental Type E: Wet Areas.

Additional information about Phase 1 can be found in the Phase 1 final report (Hopkinson et al. 2015).

\subsubsection{Phase 1 Objectives}

Four test plots were created to test seed mixtures. Each of the four test plots had a different objective. The results were intended to give feedback that would aid in revising the entire WVDOH Specification 652. The different objectives were as follows: 
- Compare current WVDOH seed mixtures to the new experimental seed mixtures

- Test the effectiveness of proposed high elevation seed mixtures

- Investigate the results of seed bed preparation on vegetation cover

- Evaluate different soil amendments on vegetation cover 


\subsection{Long-Term Monitoring}

\subsection{Introduction}

Monitoring native and introduced roadside vegetation over multiple growing season can help develop management techniques to preserve native vegetation and limit invasive species (Rentch et al. 2005). Skousen and Venable (2008) found that it took approximately three growing season to establish native vegetation ground cover by seeding disturbed land along West Virginia highways. Establishment of native vegetation can vary highly depending on site conditions such as previous vegetation, previous soil conditions, and surrounding vegetation (Daehler 2003). Native vegetation tends to establish slowly but produce more than adequate ground cover over time (Skousen and Venable 2008). Native and introduced seed mixtures often result in introduced species establishing the first year while native species tend to take over a year to develop (Holl 2002).

Over time, sites will be shaped by different abiotic and biotic factors that can take anywhere from months to decades to be observed (refer to Table 1 for examples). Examples of these influences include large storm events and species competition. Long-term observation allows for further remediation of disturbed land by analyzing and identifying the key factors that affect vegetation over time (Bakker 1996). Some of these factors include changes in biodiversity, anthropogenic influences, climate change, and natural disasters (Fukami and Wardle 2005). Along roadways, species can easily be introduced into developing or established vegetation by means of animals, wind, and traffic (Rentch et al. 2005). If long-term factors are affecting proposed seed mixtures, seed bed preparation, or soil amendments, this can be observed and corrected during multi-season monitoring and further update WVDOH Specifications. Long-term monitoring of factors affecting experimental seed mixtures, seed be preparation, and soil amendments is discussed in the following sections.

\subsubsection{Objectives}

The overall objective was to evaluate updated seeding and mulching procedures at roadside locations over multiple growing seasons. Specific objectives included the following:

- Evaluating the long-term performance of new native and non-native seed mixtures to current WVDOH specification seed mixtures

- Determine success of an experimental native high elevation seed mixture compared to other experimental mixtures and current WVDOH mixtures

- Assessing the effects of seed bed preparation on vegetation growth over multiple seasons

- Evaluating the effect of soil amendments on vegetation performance one to two years after planting 


\subsection{Background}

An invasive species is defined as a species that spreads without human conveyance and causes negative impacts to other plant species currently inhabiting an area. A non-native species differs because it is a species that is transported by humans through a barrier that it would otherwise not be able to cross. It has been shown that species variation increases over time. Specifically, native species have been proven to allow weed species invasion over time (Alpert et al. 2000).

Some species that are non-native may appear to be non-invasive at first, but become invasive over time. Invasiveness of a species can be affected by temperature and rainfall as well as habitat. For example, anthropogenic changes of existing land (i.e. land use changes affecting the chemical composition of soil) can increase or decrease specific species invasiveness. Non-native species may also be non-invasive in one area, but invasive in an adjoining area (Alpert et al. 2000). Therefore, it is critical to monitor long-term vegetation of planted seed mixtures.

Native species encourage long-term growth of vegetation because of their natural potential for reproduction and adaptation to a specific area (Handel et al. 1994). Native seeds may take longer to germinate and establish vegetation; as a result, it is important to include non-native seeds in a mixture that will quickly germinate and establish to minimize the detrimental effects of disturbed land on erosion, runoff, and loss of ecosystem diversity (Skousen and Venable 2008, Rentch et al. 2005). Skousen and Venable (2008) showed that it is important to include annual and biennial grasses when seeding West Virginia highway construction sites to provide quick ground vegetation cover for erosion control while native seed mixtures are still germinating and developing.

It is also important to have species variation in the seed mixtures to support a diverse ecosystem. Degree of disturbance impacts the amount of species variation in seed mixtures required to successfully revegetate the land (D'Antonio and Meyerson 2002). Lesica and Allendorf (1999) suggested that highly disturbed sites, such as those resulting from construction activities, require very diverse seed mixtures to maintain adequate vegetation cover over time. If the size of the disturbance is large, variation in plants is required to establish vegetation in such an extreme situation.

Invasive species of vegetation can change biogeochemical and hydrological cycles as well as geomorphological processes (Blossey 1999). Invasive species can cause disease and competition to native species. Whole ecosystems become altered, and habitat restoration is difficult. After land is disturbed, invasive plant species can take root in the land even if they were not present on the site prior to disturbance. Blossey and Nötzold (1995) observed that invasive species of plants tend to grow and reproduce more in a non-native environment than in their own environment. Extreme anthropogenic disturbance, such as construction, can completely change an environment; land that was once inhabited by native vegetation can become more favorable of invasive species (Byers 2002). 
Insects and animals that are native to an area feed from native vegetation. If this vegetation is unavailable, these animal and insect species will become less abundant, changing the ecosystem of an area. Some animals and insects even require native vegetation for their habitat (Lesica and Allendorf 1999). Anthropogenic disturbance (e.g. construction activity) is one of the biggest factors leading to invasive species dominance on a site. It is important to introduce native species to disturbed sites before exotic species become abundant (Seabloom et al. 2003).

Newman and Redente (2001) evaluated test plots seeded with three different mixtures: native, introduced, and a combination mixture. The mixtures were evaluated for 20 years. Results showed that $67 \%$ and $72 \%$ of the planted species in the combination and native seed mixtures, respectively, were still present after 20 years, as opposed to $44 \%$ of the species planted in the introduced seed mixture. Newman and Redente (2001) proposed that this may be a result of the competitive nature of the introduced species. When comparing the results from their study to a local undisturbed vegetated area, the combination and native mixtures also had similar species richness as the reference area (Table 1).

Thompson et al. (2001) established 36 test plots $(6.5 \mathrm{ft}$ x $6.5 \mathrm{ft})$ in established grassland. Disturbance and productivity were randomly distributed among the plots. Disturbance was defined by cutting gaps in the grass or mowing at different heights. Fertilizer amounts were varied among the plot in a matrix that did not allow fertility and disturbance to be independent of each other. Fertility was found to have little effect on species composition in the first year while high disturbance allowed invasive species to be introduced. After three years however, invasiveness increased significantly with increasing fertility and disturbance. Burke and Grime (1996) also varied disturbance and soil fertility within their plots. They identified species on the existing site before establishing 3011.8 in x 11.8 in quadrats. Each plot was split into 25 subplots where disturbance and fertility were varied throughout. Their results identified seedling size as a major contributing factor in success of species used to revegetate a disturbed area; small seeded species were found to depend mostly on disturbance while large seeded species establishment was independent of either variable (Table 1).

Bochet et al. (2010) focused on roadside vegetation. Forty-six roadslopes were examined and used as guidance when selecting species that could be successful in roadslope construction revegetation. Once successful species were identified, they were compared to commercial seed mixtures commonly used to vegetate roadslopes. Twelve $13.1 \mathrm{ft}$ x $13.1 \mathrm{ft}$ plots were used to test treatments. Selected native species seed mixtures were found to cost 30 times more than a standard commercial seed mixture but taking into account the ecological and geomorphological benefits of seeding with native mixtures reduced this cost to only twice as much. (Table 1).

Clarke et al. (2005) established two study sites $164 \mathrm{ft}$ apart with 24 plots each (26.2 ft x $3.28 \mathrm{ft}$ ). Species were identified and placed into groups of five different types of vegetation. They found that ground cover by invasive Cenchurs grass increased over time, therefore decreasing species richness. Cenchurs increased from $5 \%$ ground cover initially to $80 \%$ over time (Table 1). 
Table 1: Vegetation monitoring studies

\begin{tabular}{|c|c|c|c|c|c|}
\hline $\begin{array}{l}\text { Study } \\
\text { Vegetation }\end{array}$ & Objective & $\begin{array}{l}\text { Length of } \\
\text { Monitoring }\end{array}$ & Data Collection & Summary of Results & Reference \\
\hline $\begin{array}{l}\text { Test plots: } \\
\text { introduced; } \\
\text { native; } \\
\text { introduced } \\
\text { and native }\end{array}$ & $\begin{array}{l}\text { Determine effects of } \\
\text { different treatments on } \\
\text { plant production and } \\
\text { species diversity }\end{array}$ & $1977-1997$ & $\begin{array}{l}\text { Biomass; Species } \\
\text { richness }\end{array}$ & $\begin{array}{l}\text { Native mixtures produced } \\
\text { most biomass on irrigated } \\
\text { plots; biomass was the } \\
\text { same on non-irrigated } \\
\text { plots; native mixtures had } \\
\text { the highest percentage of } \\
\text { planted species }\end{array}$ & $\begin{array}{l}\text { Newman } \\
\text { and } \\
\text { Redente } \\
2001\end{array}$ \\
\hline $\begin{array}{l}\text { Test plots: } 54 \\
\text { native species } \\
\text { not originally } \\
\text { present }\end{array}$ & $\begin{array}{l}\text { Identified factors of } \\
\text { invasions and } \\
\text { characteristics of invasive } \\
\text { species }\end{array}$ & 1991-1995 & $\begin{array}{l}\text { Percent by } \\
\text { species; soil pH }\end{array}$ & $\begin{array}{l}\text { Invasion success } \\
\text { dependent on: number of } \\
\text { propagules, characteristics } \\
\text { of species, susceptibility } \\
\text { of environment; low soil } \\
\text { pH decreased invasion; no } \\
\text { specific plant trait was } \\
\text { evident as invasive }\end{array}$ & $\begin{array}{l}\text { Thompson } \\
\text { et al. } 2001\end{array}$ \\
\hline $\begin{array}{l}\text { Herbaceous } \\
\text { layer of semi- } \\
\text { arid } \\
\text { vegetation }\end{array}$ & $\begin{array}{l}\text { Determine growth/response } \\
\text { of vegetation over time due } \\
\text { to rainfall and presence of } \\
\text { invasive species since } \\
\text { ceasing of grazing }\end{array}$ & $1976-2004$ & $\begin{array}{l}\text { biomass; species } \\
\text { abundance; } \\
\text { rainfall; fire } \\
\text { history; soil } \\
\text { variability; } \\
\text { colonization of } \\
\text { plants by } \\
\text { Cenchrus cilaris }\end{array}$ & $\begin{array}{l}\text { Cenchrus cilaris showed } \\
\text { significant correlation } \\
\text { with decline of native } \\
\text { species; increase in native } \\
\text { grass during summer } \\
\text { rainfall; increase in native } \\
\text { forbs in winter rainfall }\end{array}$ & $\begin{array}{l}\text { Clarke et } \\
\text { al. } 2005\end{array}$ \\
\hline $\begin{array}{l}\text { Limestone } \\
\text { grassland }\end{array}$ & $\begin{array}{l}\text { Determine plant } \\
\text { characteristics that } \\
\text { contribute to species } \\
\text { invasion by controlling gap } \\
\text { sizes and mowing heights }\end{array}$ & $1991-1992$ & $\begin{array}{l}\text { Species } \\
\text { abundance }\end{array}$ & $\begin{array}{l}\text { Higher levels of } \\
\text { disturbance correlated } \\
\text { with more invasive } \\
\text { species (e.g. Bare ground } \\
\text { strongly correlated with } \\
\text { invasives) }\end{array}$ & $\begin{array}{l}\text { Burke and } \\
\text { Grime } \\
1996\end{array}$ \\
\hline $\begin{array}{l}\text { Native } \\
\text { species }\end{array}$ & $\begin{array}{l}\text { Determine how to select } \\
\text { suitable native species for a } \\
\text { selected roadsides; conduct } \\
\text { vegetation studies using } \\
\text { determined procedures; } \\
\text { evaluate cost effectiveness } \\
\text { of native species in } \\
\text { hydroseeding over } \\
\text { commercial mixtures }\end{array}$ & $2004-2007$ & $\begin{array}{l}\text { Roadside flora } \\
\text { surveys; } \\
\text { percentage of } \\
\text { roadslopes; } \\
\text { aspect; percent } \\
\text { by species; } \\
\text { percent ground } \\
\text { cover }\end{array}$ & $\begin{array}{l}8 \text { successful species } \\
\text { chosen; native mixtures } \\
\text { performed significantly } \\
\text { better than commercial } \\
\text { mixtures with respect to } \\
\text { ground cover and species } \\
\text { abundance; cost difference } \\
\text { was outweighed by } \\
\text { increased native mixture } \\
\text { performance }\end{array}$ & $\begin{array}{l}\text { Bochet et } \\
\text { al. } 2010\end{array}$ \\
\hline
\end{tabular}

Growing degree days (GDD) is a common heat unit measurement that can be used to predict development and growth of plants. GDD is measured using the minimum and maximum daily temperatures and a selected base and upper temperature to satisfy the chosen plant. Base and maximum temperatures are plant-based temperature thresholds that indicate when the plant becomes dormant and development ceases. Based on the calculation, one degree day is considered as one day when the mean daily temperature is at least one degree above the base temperature. Plant growth can also be affected by moisture but GDD only accounts for temperature because air temperature is the most important environmental factor affecting plant growth and development (Frank 1996; Miller et al. 2001). 
GDD can be used to determine developmental stages for new seedling growth or perennial grass development. Frank and Hofmann (1989) found GDD to be the primary controlling variable in development of plants. GDD can be used to predict emergence of perennial warm-season and cool-season grasses. It is used to measure growth and development because it is more accurate than prediction using calendar days (Miller et al. 2001). Growing degree days are accumulated throughout the entire growing season and can be compared to ground cover and weight of vegetation to determine the developmental stage of plants. It has been found that native grasses require more GDD to develop than introduced or invasive species (Frank 1996; Bartholomew and Williams 2005). Biomass and ground cover can be predicted using growing degree days. For example, increasing temperatures can increase vegetation growth rate but may also decrease biomass if increased temperatures are sustained for too long (Nearing et al. 2005).

\subsection{Methods}

This work addresses long-term vegetation persistence and includes monitoring of the second and third growing seasons of established field plots. Data collection occurred once a month from June through October in 2016 and 2017. Field plot installation and data collection are described in the following sections.

\subsubsection{Test Plots}

Four test plots located along Corridor H (U.S. 48) were evaluated over three growing seasons. The plots were constructed by Hilvers (2015) in May 2015. Details about plot construction can be found in Hilvers (2015), Hopkinson et al. (2015), and Hilvers et al. (2017). A brief description of the field sites with treatment locations follows. The location of each subplot within the plots was randomly selected. Before installing the plots, soil samples were taken from each site and sent to AgSource Laboratories in Lincoln, Nebraska.

\subsubsection{Plot CH-1A: Testing Seed Mixtures}

Plot $\mathrm{CH}-1 \mathrm{~A}$ was intended to compare experimental seed mixtures to the current mixtures used by the WVDOH. Existing vegetation and debris were removed and a fence was installed. Planting procedures followed WVDOH specifications for permanent seeding (WVDOH 2010). Fertilizer was included as designated by soil tests and ProMatrix ${ }^{\mathrm{TM}}$ Engineered Fiber Matrix (EFM) by Profile Products was used as the mulch. Six seed mixtures (i.e. WVDOH cut/fill and medians, and experimental mowable areas, high elevation, cool season, and warm season) were tested at the plot in $3 \times 6$ subplots. Three replications of each seed mixture were included (Figure 1). 


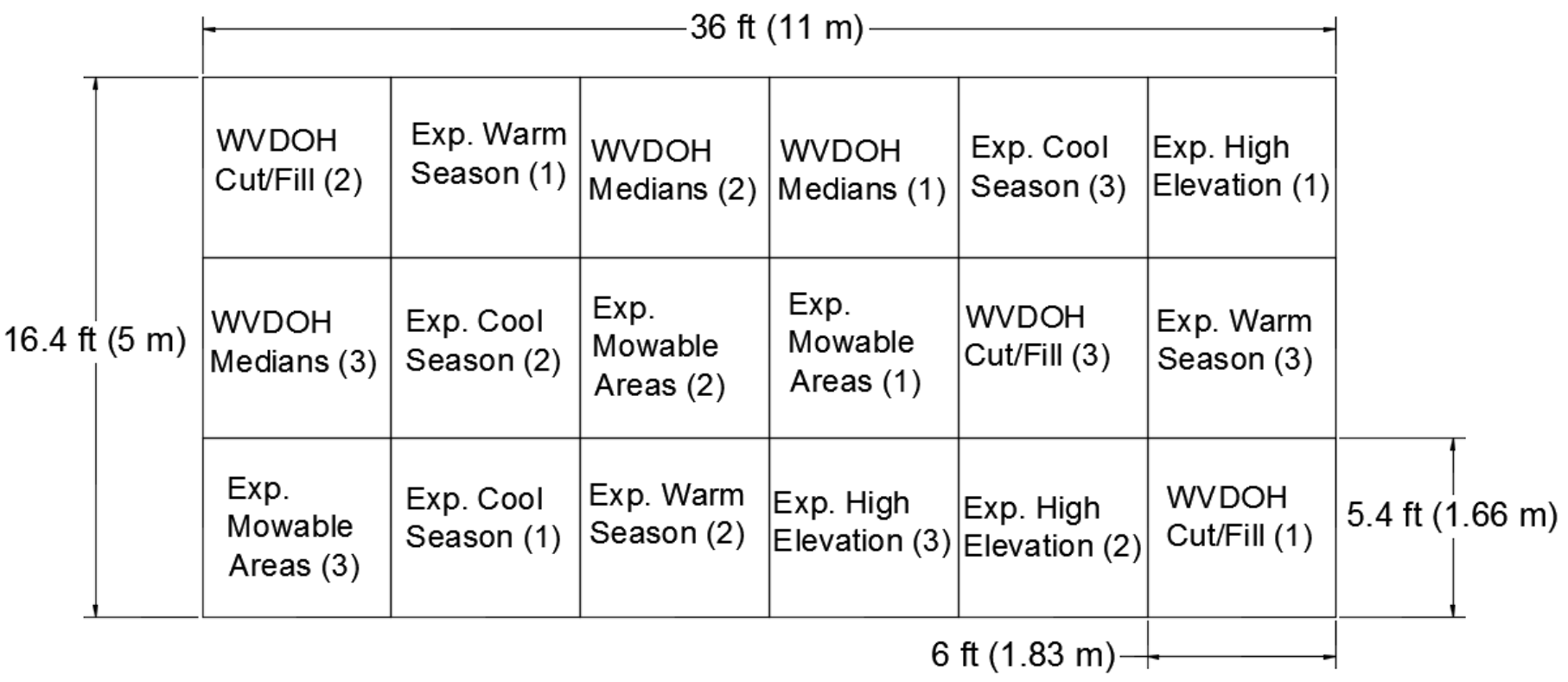

Figure 1: CH-1A subplot layout

\subsubsection{Plot CH-2: Testing Experimental High Elevation Seed Mixture}

CH-2 was planned to test experimental high elevation seed mixtures. The same steps were followed to prepare plot $\mathrm{CH}-2$ for planting and site preparation as were followed for $\mathrm{CH}-1 \mathrm{~A}$. Fertilizer and seed amounts were also determined the same way and applied in the same order as CH-1A. Lastly, the same HECP type and amounts were used. Three other seed mixtures were planted as well as experimental high elevation (i.e. experimental mowable areas, warm season, and cool season, and WVDOH medians). Three replications of each seed mixture were arranged randomly in 15 subplots ( 3 x 5) (Figure 2). 


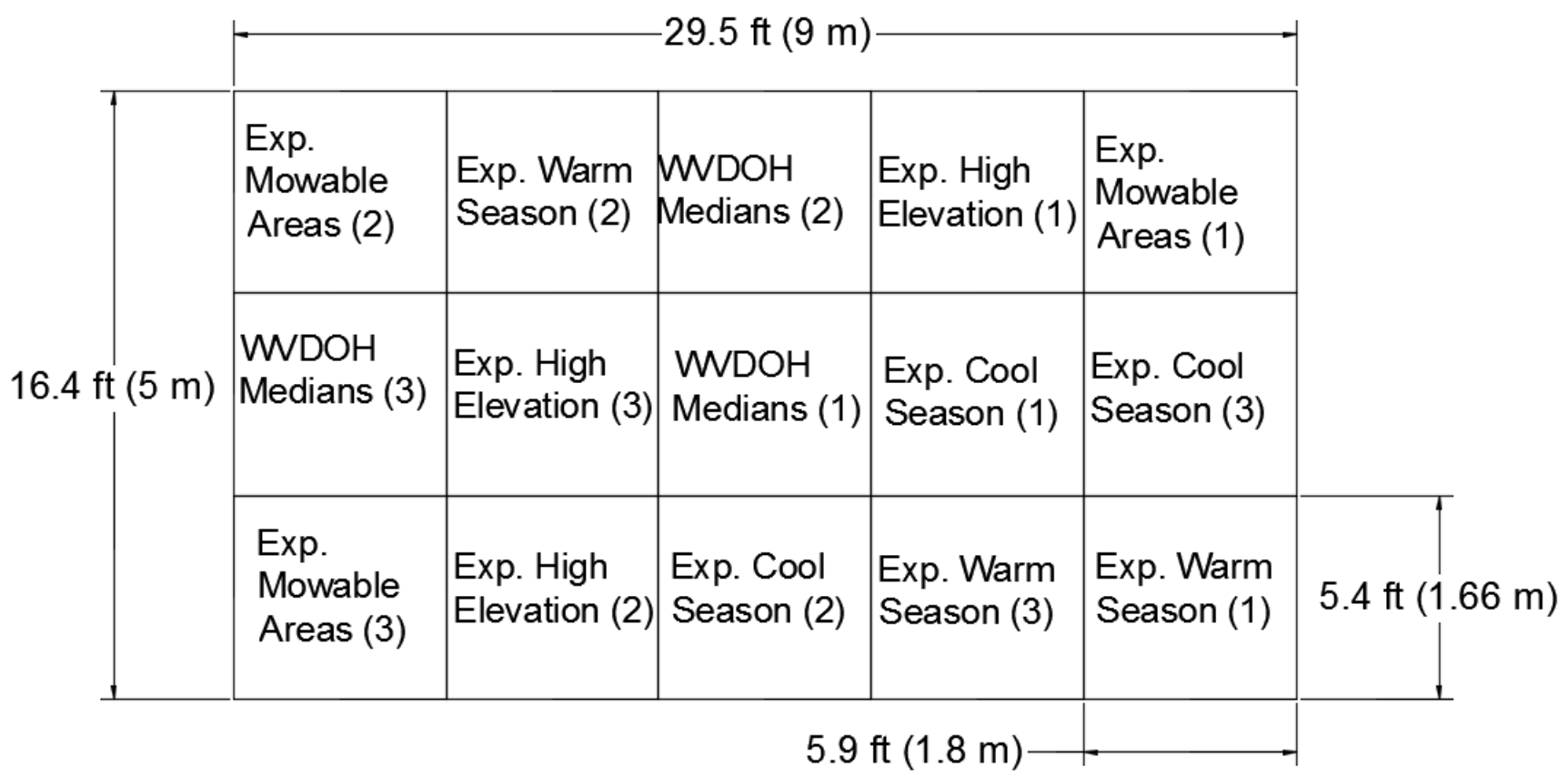

Figure 2: CH-2 subplot layout

\subsubsection{Plot CH-3: Testing Seed Bed Preparation Techniques}

CH-3 was established to assess seed bed preparation on resulting vegetation. The subplots in CH-3 were designed with two replications of four seed bed treatments (i.e. topsoil with straw mulch, topsoil with HECP, existing soil with straw mulch, and existing soil with HECP) for each of the three seed mixtures planted (experimental warm season and cool season and WVDOH medians) in 4 x 6 subplots. Methodology for preparing the seed bed was the same as $\mathrm{CH}-1 \mathrm{~A}$ and $\mathrm{CH}-2$, except for the use of topsoil in some subplots. After determining the correct amounts, application of fertilizer, seed, and inoculant were the same as the previous plots. HECP and straw mulch with a tackifier were applied to respective subplots (Figure 3). 


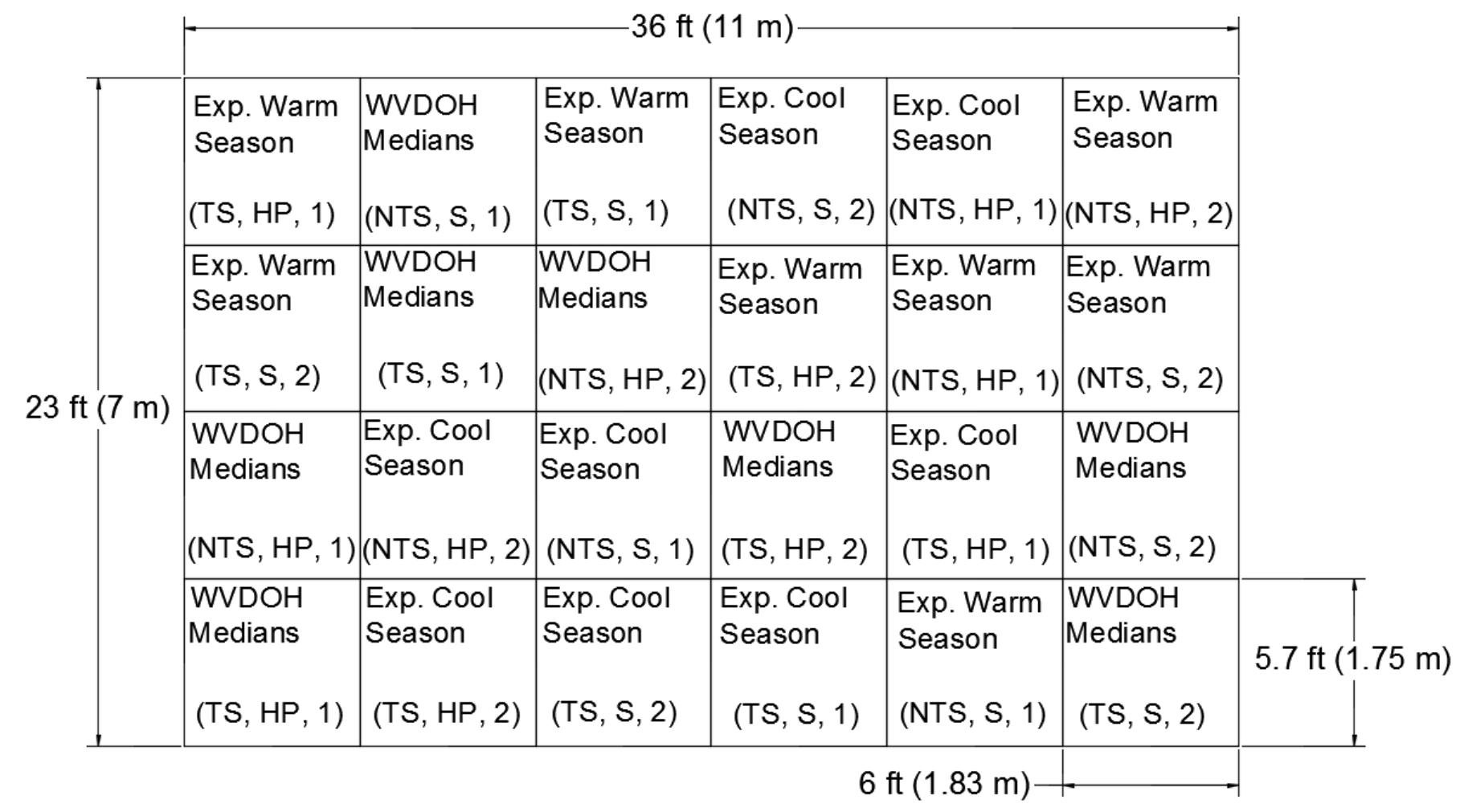

Figure 3: CH-3 subplot layout (TS=topsoil; NTS=no Topsoil; $S=$ =straw Mulch; HP=hydraulic erosion control product)

\subsubsection{Plot CH-1B: Testing Soil Amendments}

$\mathrm{CH}-1 \mathrm{~B}$ was located directly beside $\mathrm{CH}-1 \mathrm{~A}$. The plots were enclosed in the same fence. The intent of this plot was to evaluate the effect of different soil amendments on vegetation. The entire plot was planted with experimental mowable areas seed mixture in $3 \times 4$ subplots. Preparation of the subplots planted with and without topsoil followed CH-3. Other subplots were prepared with respective soil amendments (i.e. ProGanics ${ }^{\mathrm{TM}}$ Biotic Soil Media ${ }^{\mathrm{TM}}\left(\mathrm{BSM}^{\mathrm{TM}}\right)$ by Profile Products, LLC and Biotic Earth ${ }^{\mathrm{TM}}$ Black Hydraulic Growth Mediums (HGM) (Figure 4). 


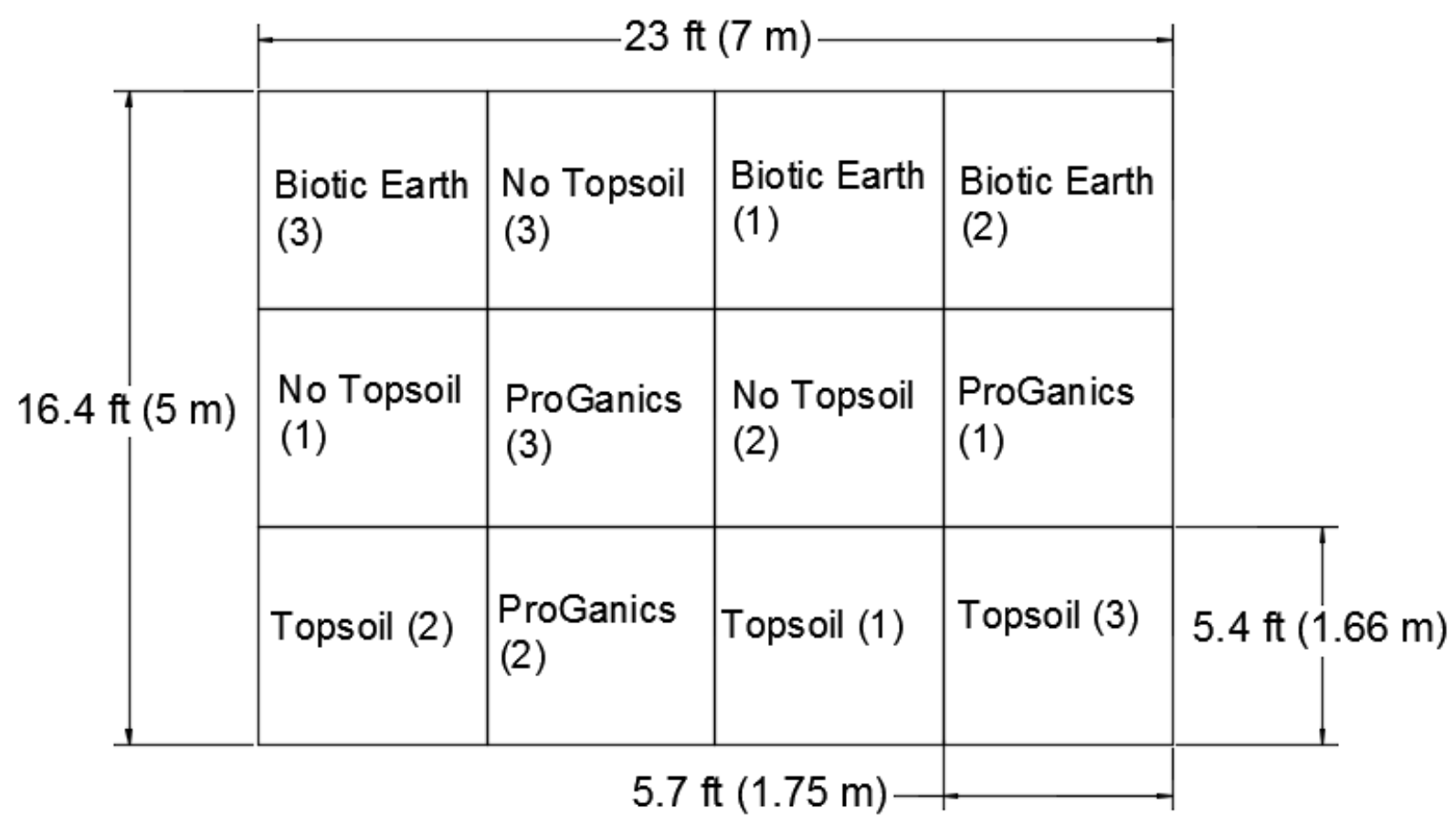

Figure 4: CH-1B subplot layout

\subsubsection{Precipitation and Temperature}

Precipitation was collected in three WatchDog Tipping Bucket Rain Gauges located at CH-1, $\mathrm{CH}-2$, and $\mathrm{CH}-3$. Precipitation data were measured every ten minutes and recorded on a Spectrum Technologies WatchDog 1425 Micro Station at each location. Temperature was recorded every ten minutes on the same device by an internal temperature sensor. Monitoring data were downloaded monthly from the start of the growing season until the sensors were removed at the end of each growing season. Data were recorded by SpecWare 9 Professional computer software.

Growing degree days (GDD) were recorded based on the daily maximum and minimum temperatures. Input values for base temperature and maximum temperature were chosen to be 50 ${ }^{\circ} \mathrm{F}\left(10^{\circ} \mathrm{C}\right)$ and $90{ }^{\circ} \mathrm{F}\left(32.2^{\circ} \mathrm{C}\right)$ because these are within a recommended range of values for warm and cool season species (Bonhomme 2000). If the minimum temperature was below the base temperature, the base temperature was used in place of the minimum temperature. If the maximum temperature was above the upper limit temperature the upper limit temperature was used in place of the maximum temperature (Equation 1). Accumulated growing degree days were recorded for each growing season. GDD was calculated using SpecWare 9 Professional computer software. 


$$
\frac{T_{\max }+T_{\min }}{2}-T_{\text {base }}
$$

Where, $T_{\max }=$ the maximum daily temperature $\left({ }^{\circ} \mathrm{F}\right)$

$T_{\min }=$ the minimum daily temperature $\left({ }^{\circ} \mathrm{F}\right)$

$T_{\text {base }}=$ a plant-specific base temperature $\left({ }^{\circ} \mathrm{F}\right)$

\subsubsection{Vegetation}

Ground cover measurements taken during the second and third growing seasons (June 2016October 2017) in this study used methods based on Elzinga et al. (1998) and Calloudon et al. (1996) as reported by Hilvers (2015). A Vegetation Measuring Device (VMD) was used to collect ground cover data. The device was a $3.3 \mathrm{ft}(1 \mathrm{~m})$ long square made of PVC. A grid of strings that consisted of 100 intersections was used to measure ground cover. Pictures of each subplot containing the VMD and an individual name tag were taken with a Nikon COOLPIX AW100 camera every time ground cover data were collected.

Ground cover by species measurements were taken at the end of the second and third growing seasons. Individual species by area in each subplot within the four plots were identified by analyzing photographs in Adobe Photoshop CC 2015. Methodology was similar to that of Dietz and Steinlein (1996). All planted species were identified. Species that were found in the subplots that are not included in the seed mixture were included in the category "not planted." Any location without cover or with dead vegetation was marked as "no cover." Respective percentage by area of forbs, legumes, and graminoids were also found for each plot.

Biomass samples were collected from each subplot near the end of each growing season (i.e. November 2016 and July 2017). Methodology for biomass collection was similar to that of Franks and Goings (1997).

\subsubsection{Soil}

Soil compaction was measured in June and October 2016 and June 2017 using an AgraTronix Soil Compaction Tester that complies with ASCE standard S313.3. Compaction methodology follows ASAE EP542 code. Table 2 shows how compaction was recorded for each color. Compaction is considered good, moderate, poor, and severe for ranges associated with green, yellow, red, and max, respectively. 
Table 2: Compaction recording scale

\begin{tabular}{cccc}
\hline Color & Scale & Rating & Infiltration Rate \\
\hline Green & $2.5-3$ & Good & High \\
\hline Yellow & $2-2.5$ & Moderate & Medium \\
\hline Red & $1.0-2.0$ & Poor & Low \\
\hline Max & $0-1.0$ & Severe & Very Low \\
\hline
\end{tabular}

Soil samples were collected with a 2.5 in $(6.4 \mathrm{~cm})$ diameter auger in October 2016. Soil testing methodology followed suggestions by West Virginia University Soil Testing Laboratory (2007) for lawn and turf testing. At $\mathrm{CH}-2$ and $\mathrm{CH}-1 \mathrm{~A}$, a composite sample was taken composing of five subsamples: one from each of the four corners and one from approximately the middle of each plot. At CH-1B, four soil samples were taken to represent topsoil, no topsoil, ProGanics, and Biotic Earth plots. Each of the four samples composed of two subsamples from two of the representative plots. The same method was used at $\mathrm{CH}-3$ as $\mathrm{CH}-1 \mathrm{~B}$. The four representative samples taken were for the four different seed bed preparations: no topsoil with straw, no topsoil with HECP, topsoil with straw, and topsoil with HECP. Soil samples were stored for an extended period then sent to AgSource Laboratories in Lincoln, NE for analysis of nutrients (N, K, and P), $\mathrm{pH}$, soluble salts, and organic matter. When collecting samples, care was taken to disturb as little vegetation within the plots as possible.

\subsubsection{Statistical Analysis}

A one-way Kruskal-Wallis test was used to compare medians of ground cover of all treatments at $\mathrm{CH}-1 \mathrm{~A}, \mathrm{CH}-2$, and $\mathrm{CH}-1 \mathrm{~B}$ for both growing seasons. Statistical significance $(\alpha=0.05)$ was determined based upon resulting observed p-values correlation to the critical value chi-square test statistic generated for each plot. Multiple comparisons of total biomass and ground cover were made for each pair of data within the treatments at $\mathrm{CH}-1 \mathrm{~A}, \mathrm{CH}-2$, and $\mathrm{CH}-1 \mathrm{~B}$ for both growing seasons. Statistical significance $(\alpha=0.05)$ was calculated using Dunn method for joint ranks with a Bonferroni adjustment (SAS Institute Inc. 2016)

A one-way blocked Kruskal-Wallis test was used to compare medians of ground cover of all treatments at $\mathrm{CH}-3$. Blocked analysis centers values of one variable around another variable called the "block variable." In this case, seed mixture and seed bed preparation were the two variables that were used as the variable of interest and as the block variable. Results from this test were used to find the statistical significance $(\alpha=0.05)$ of different seed bed preparations and seed mixtures of the plot throughout each growing season. Dunn method for joint ranking was also used to compare statistical significance $(\alpha=0.05)$ of each pair (SAS Institute Inc. 2016). Statistical analysis was completed using JMP Pro 13.0.0. 


\subsection{Results}

Results were monitored during the growing season from approximately June until October. Results are organized by major field site in the following sections. Weather and vegetation measurements are separated by growing season. All soil sample analysis results are shown together. Temperature and precipitation figures are displayed in imperial units while descriptions include both imperial and metric units. Biomass figures are displayed in metric units while descriptions include both imperial and metric units.

\subsubsection{CH-1A: Testing Seed Mixtures}

\subsubsection{Temperature and Precipitation}

\section{Second Growing Season (2016):}

Precipitation totaled 12.22 in $(31.04 \mathrm{~cm})$ for the entire season. Precipitation varied over the season with two drought periods occurring in mid-July and September. Total precipitation amounts in June, July, August, September, and October were 1.76 in $(4.47 \mathrm{~cm}), 5.28$ in $(13.4$ $\mathrm{cm}), 2.22$ in $(5.64 \mathrm{~cm}), 1.74$ in $(4.42 \mathrm{~cm})$, and 1.22 in $(3.10 \mathrm{~cm})$, respectively. The highest daily precipitation amount was 3.2 in $(8.13 \mathrm{~cm})$ and occurred on July 28 (Figure 5).

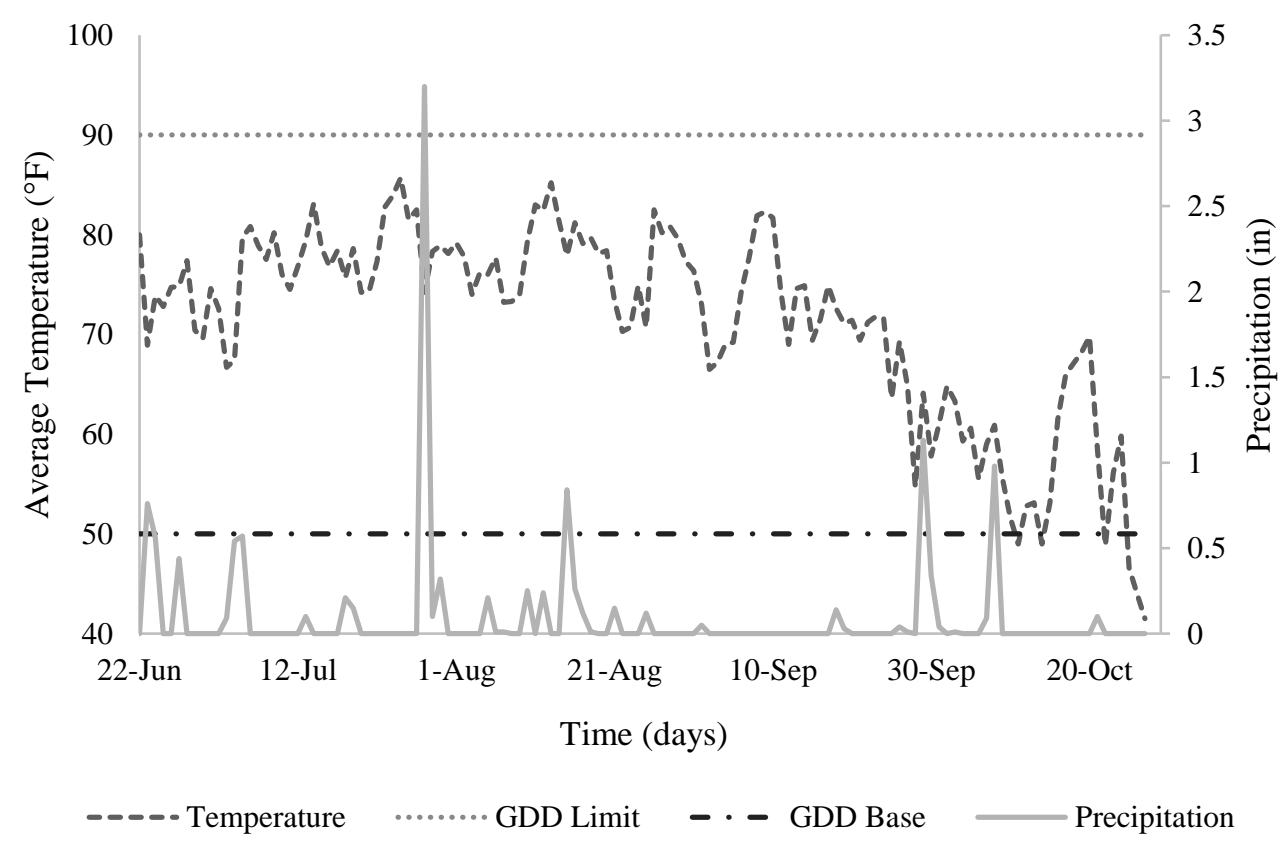

Figure 5: CH-1A distribution of air temperature and precipitation for the second growing season (JuneOctober 2016)

\section{Third Growing Season (2017):}

There was a total of 1.52 in $(3.86 \mathrm{~cm})$ of precipitation during the 12 rain days in June. The plot received 2.33 in $(5.92 \mathrm{~cm})$ of precipitation in July during 13 days of rainfall. The highest daily 
precipitation was 1.04 in $(2.64 \mathrm{~cm})$ and occurred on July 6. Average temperatures for June and July were $73.4^{\circ} \mathrm{F}\left(23^{\circ} \mathrm{C}\right)$ and $76.7^{\circ} \mathrm{F}\left(24.8^{\circ} \mathrm{C}\right)$, respectively (Figure 6).

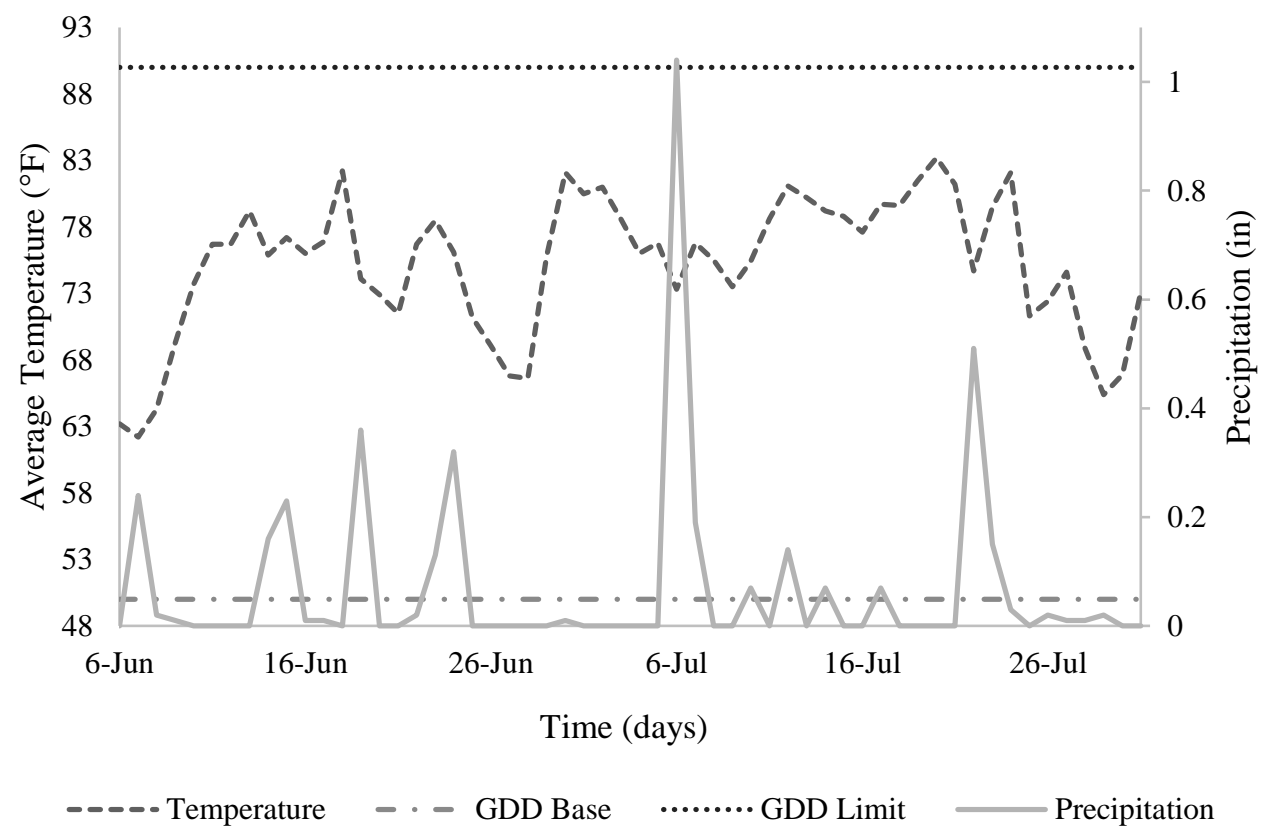

Figure 6: CH-1A distribution of air temperature and precipitation for the third growing season (June-July 2017)

\subsubsection{Vegetation}

\section{Second Growing Season (2016):}

Resulting ground cover at all subplots remained above $90 \%$ from the end of the first growing season until the end of the second growing season (Figure 7). Figure 7 includes the last data point from the first growing season (Hilvers 2015). Kruskal-Wallis (p-value $=0.1235$ ) indicated there was no significant difference in ground cover among different seed mixtures (Figure 8). 


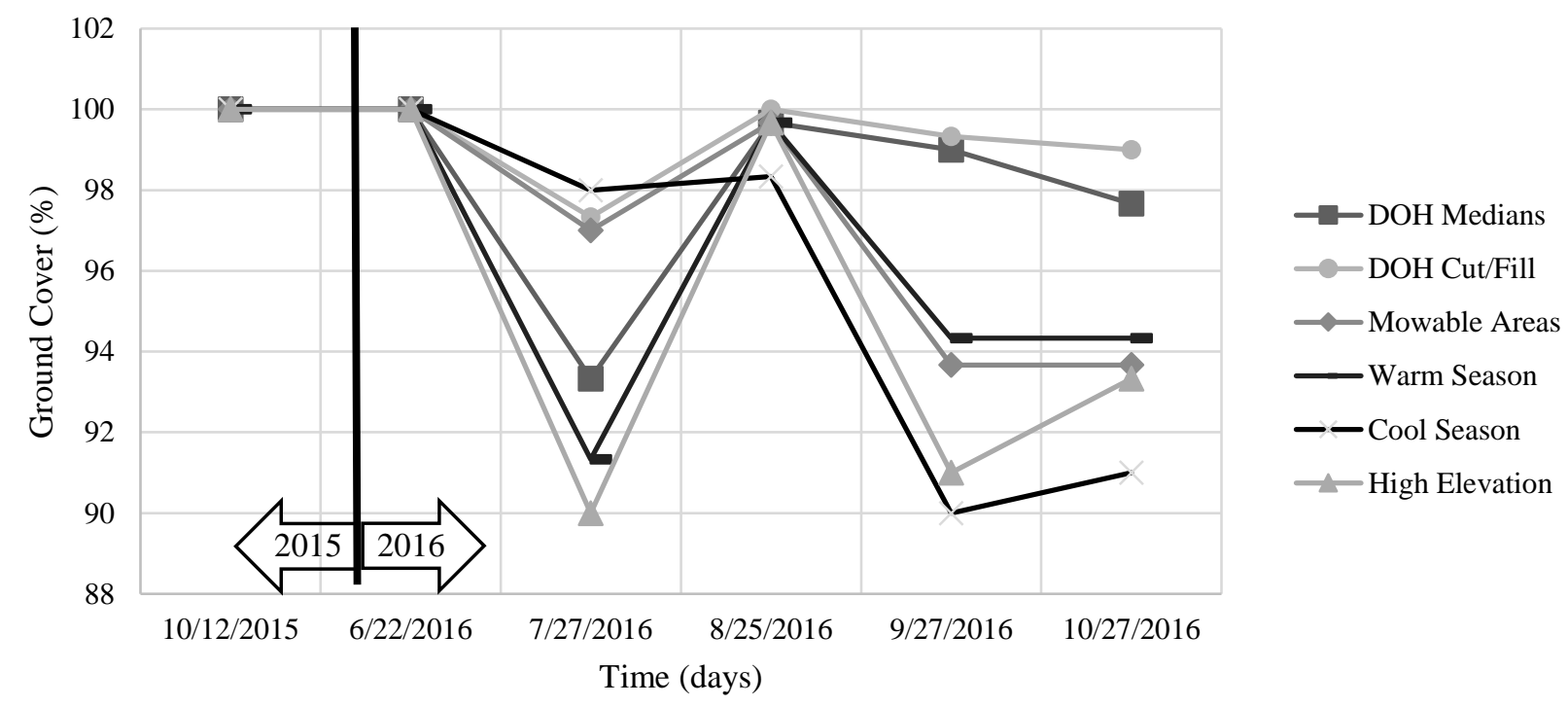

Figure 7: CH-1A second growing season average ground cover (2016)

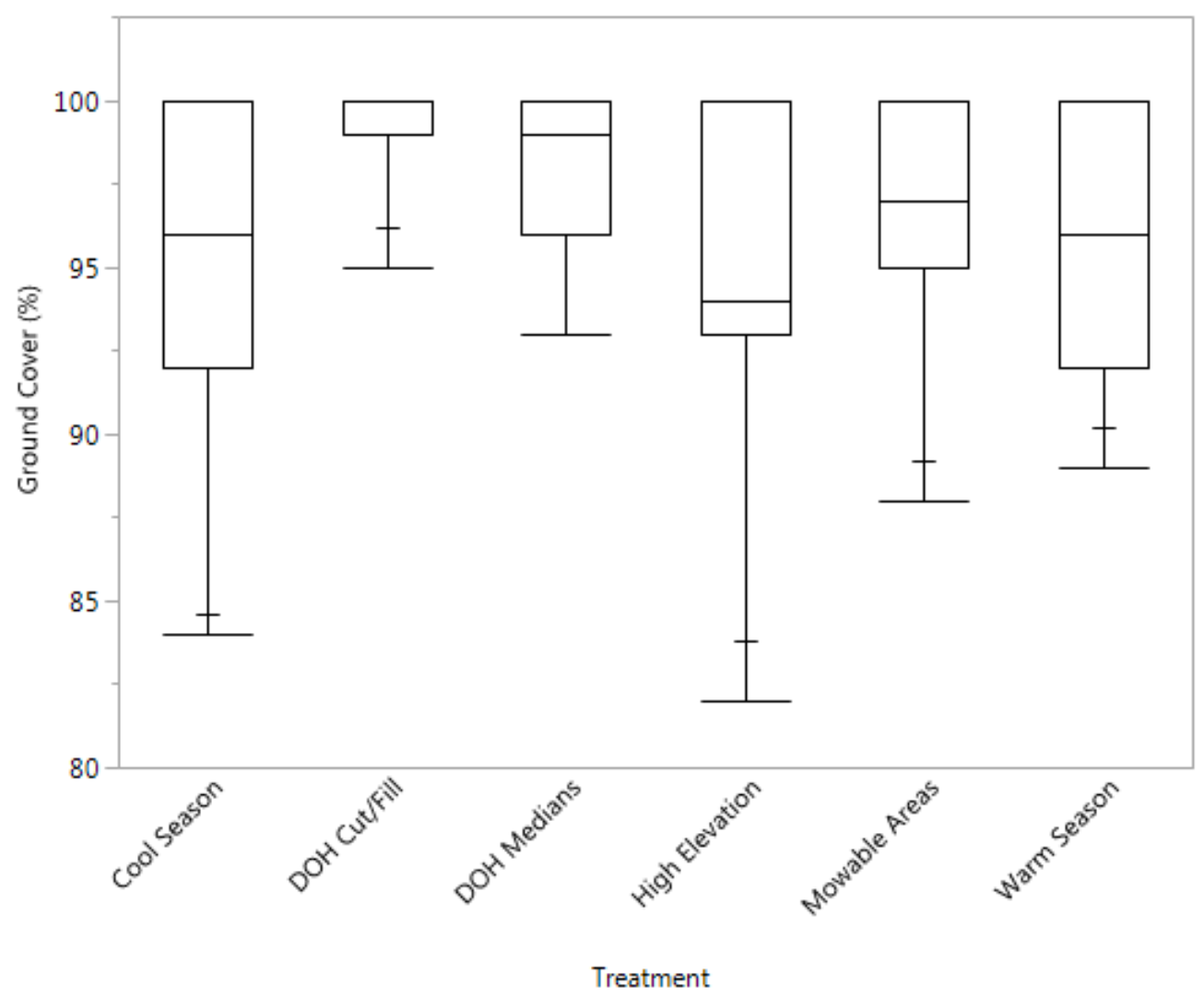

Figure 8: CH-1A distribution of ground cover for seed mixtures: cool season, DOH cut/fill, DOH medians, high elevation, mowable areas, and warm season; median (-); 25-75\% (box); $10 \%$ (-); min and max (whisker) (2016)

At the end of the second season, subplots containing experimental warm season mixtures resulted in the highest percent by area of species that were not planted. Subplots planted with 
high elevation mixtures also contained a substantial amount of species that were not planted. WVDOH medians, WVDOH cut/fill, and cool season mixture subplots resulted in at least $80 \%$ ground cover of species that were contained in the mixtures at planting (Figure 9).

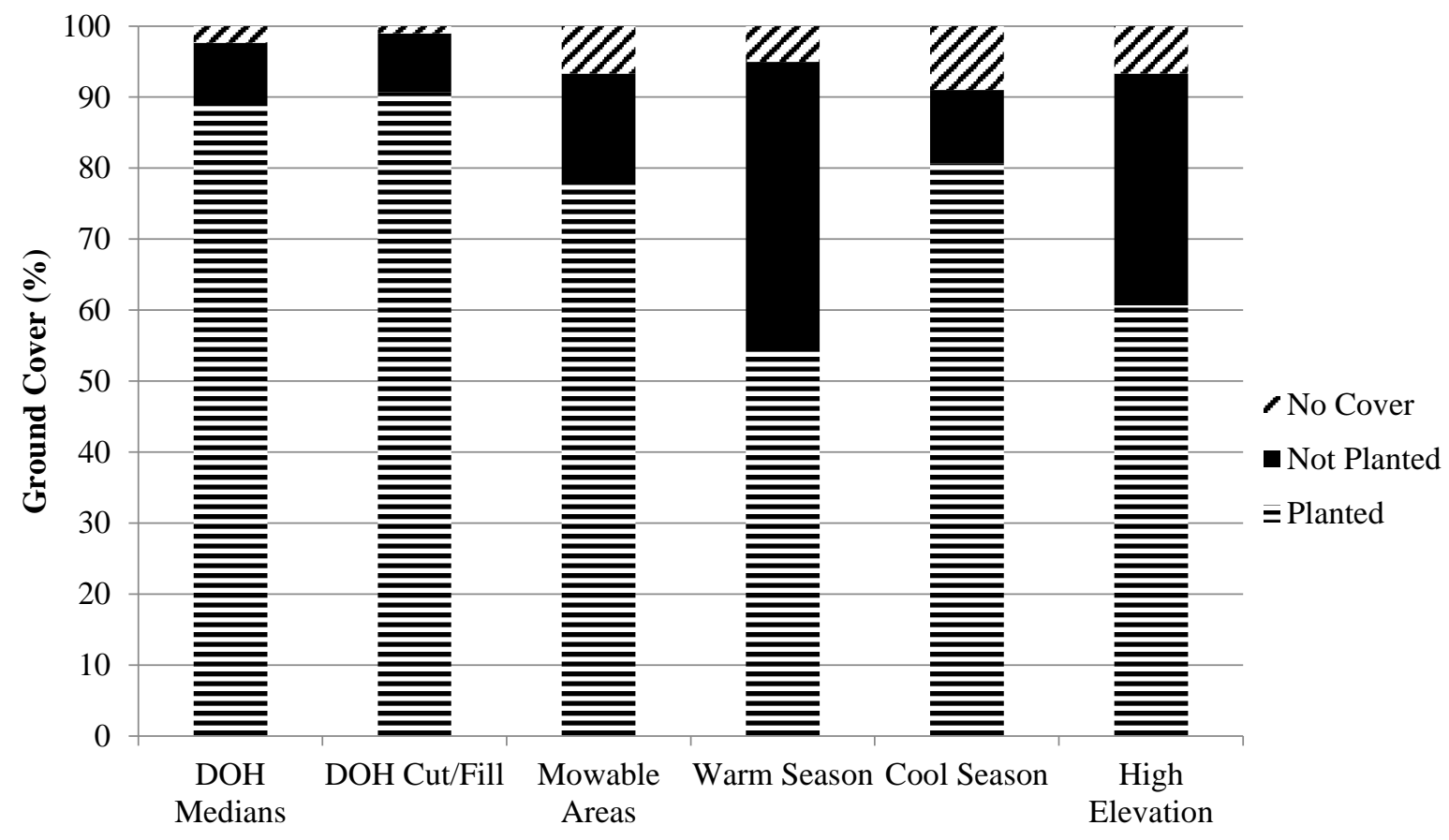

Figure 9: CH-1A average ground cover by species (October 2016)

At the end of the second season, ground cover in all subplots was dominated by graminoid species. WVDOH cut/fill mixtures, experimental high elevation mixtures, experimental cool season mixtures, and experimental mowable areas mixture subplots also resulted in some ground cover by legume species $(12.0 \%, 2.0 \%, 13.3 \%$, and $1.7 \%$, respectively). No forbs were present in the entire plot. Subplots planted with mowable areas mixture resulted in ground cover at the end of the second season that was similar to the percent composition of the mixture at planting (legume ground cover was $1.7 \%$ compared to $1.8 \%$ composed in the seed mixture). Ground cover by area varied from percent composition of each mixture due mostly to invasive or weed species being present in the plot (Table 3). 
Table 3: CH-1A average ground cover by area (October 2016)

\begin{tabular}{|c|c|c|c|c|c|}
\hline \multirow[t]{2}{*}{ Seed Mixture } & \multicolumn{5}{|c|}{ Composition of Mixture (\%) } \\
\hline & Forb & Legume & Graminoid & & \\
\hline Exp. Mowable Areas & 0.0 & 1.8 & 98.2 & & \\
\hline Exp. Warm Season & 2.9 & 1.4 & 95.7 & & \\
\hline Exp. Cool Season & 0.0 & 27.5 & 72.5 & & \\
\hline Exp. High Elevation & 3.6 & 1.6 & 94.8 & & \\
\hline DOH Medians & 0.0 & 3.3 & 96.7 & & \\
\hline \multirow[t]{3}{*}{ DOH Cut/Fill } & 0.0 & 31.7 & 68.3 & & \\
\hline & \multicolumn{5}{|c|}{ Ground Cover (\%) } \\
\hline & Forb & Legume & Graminoid & Not Planted & No Cover \\
\hline Exp. Mowable Areas & 0.0 & 1.7 & 76.0 & 15.7 & 6.6 \\
\hline Exp. Warm Season & 0.0 & 0.0 & 54.3 & 40.7 & 5.0 \\
\hline Exp. Cool Season & 0.0 & 13.3 & 67.3 & 10.3 & 9.1 \\
\hline Exp. High Elevation & 0.0 & 2.0 & 58.7 & 32.7 & 6.6 \\
\hline DOH Medians & 0.0 & 0.0 & 89.3 & 8.3 & 2.4 \\
\hline DOH Cut/Fill & 0.0 & 12.0 & 78.7 & 8.3 & 1.0 \\
\hline
\end{tabular}

Subplots planted with experimental mowable areas mixture, followed closely by subplots containing WVDOH cut and fill mixture, produced the highest total weight of vegetation by the end of the season. Subplots planted with both of these seed mixtures also had the least weight of species that were not planted. High elevation mixture subplots contained the most weight of species that were not planted (Figure 10). Mowable areas mixtures produced the most average total biomass, but paired Dunn method results indicated no statistical differences in total biomass among all pairs of seed mixtures (Figure 11). 


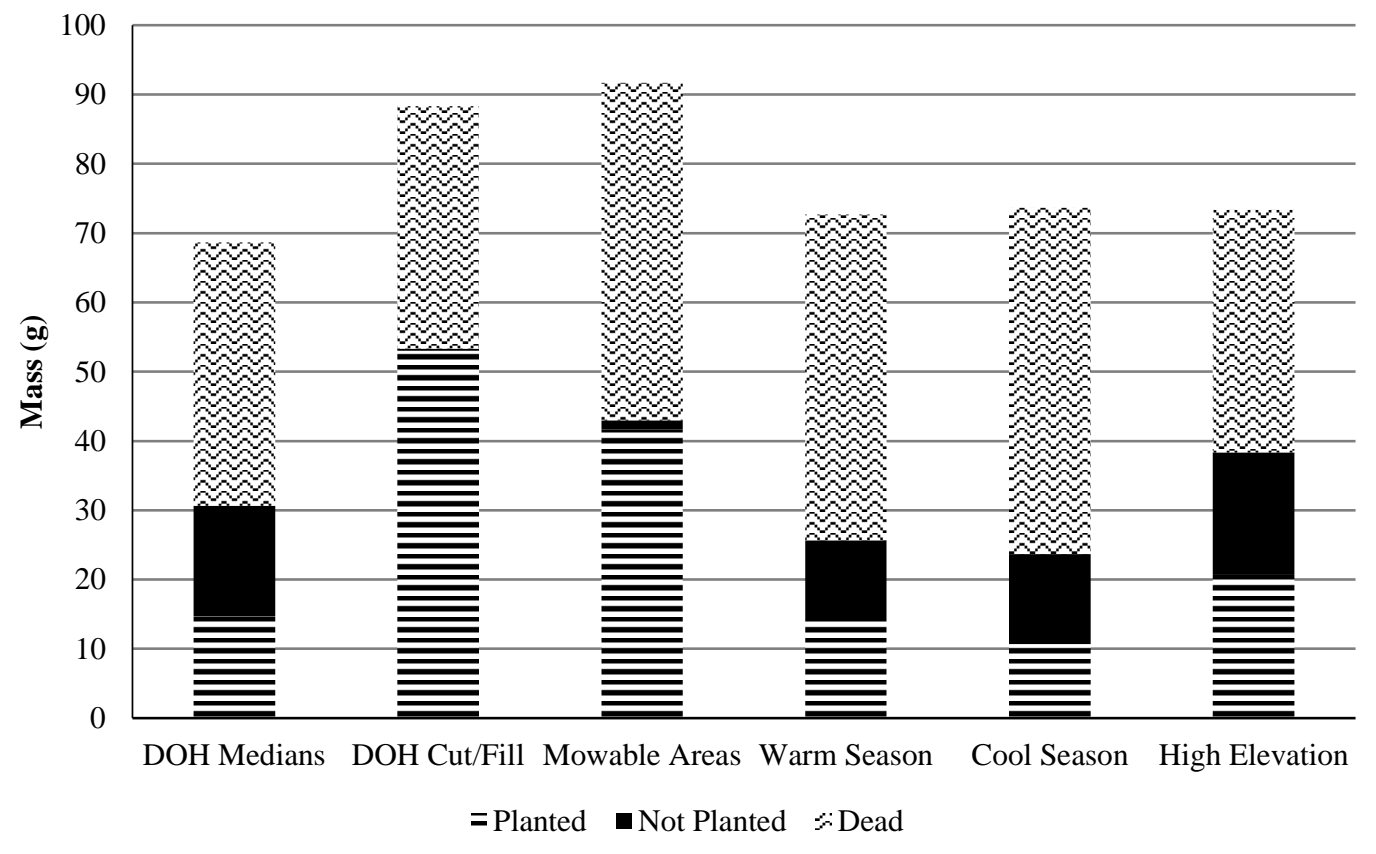

Figure 10: CH-1A total biomass weight (October 2016)

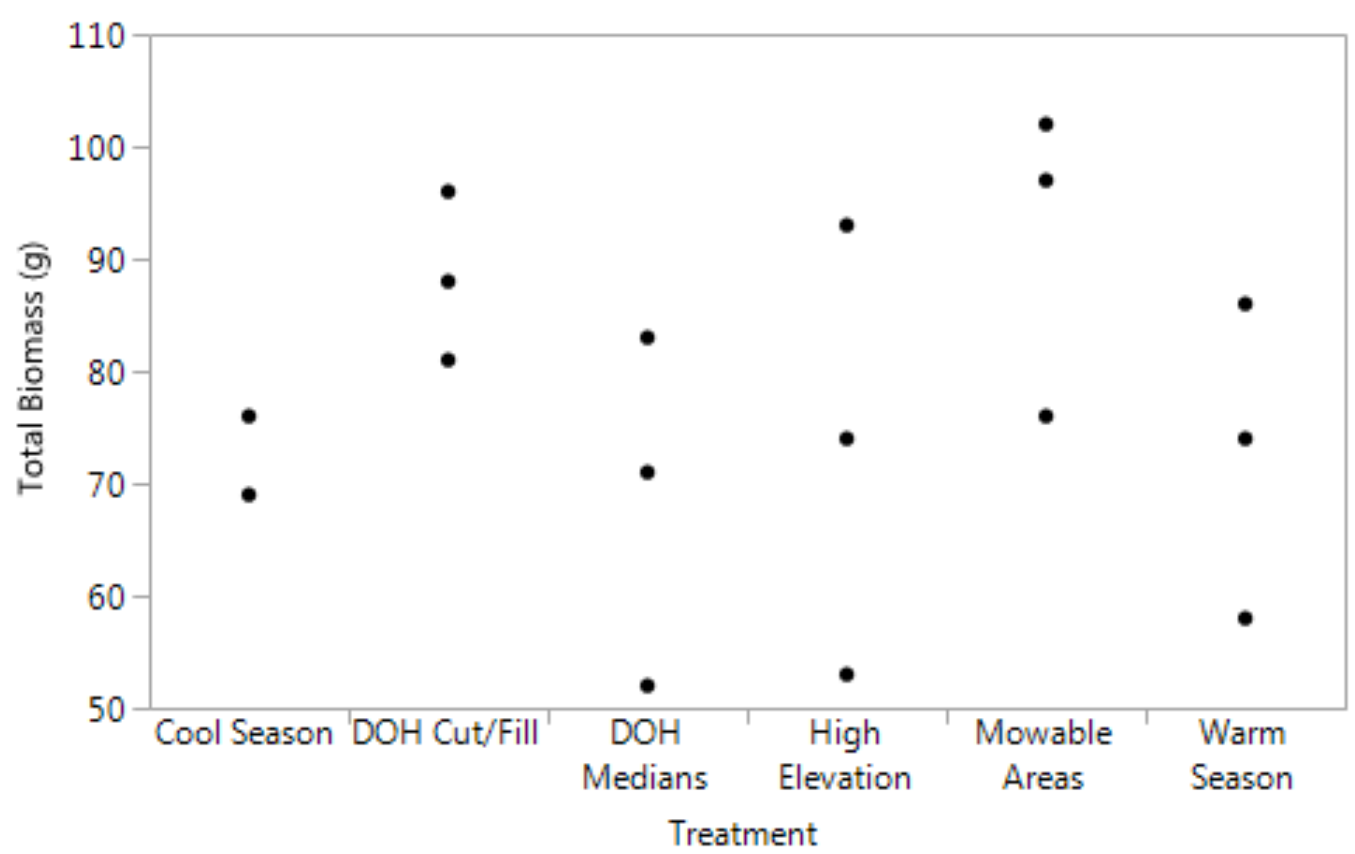

Figure 11: CH-1A distribution of biomass for six seed mixtures: cool season, DOH cut/fill, DOH medians, high elevation, mowable areas, and warm season (2016)

\section{Third Growing Season (2017):}

All subplots remained above $85 \%$ ground cover during the entire third growing season (Figure 12). Kruskal-Wallis ( $\mathrm{p}$-value $=0.1671)$ indicated no significant difference in ground cover among different seed mixtures (Figure 13). 


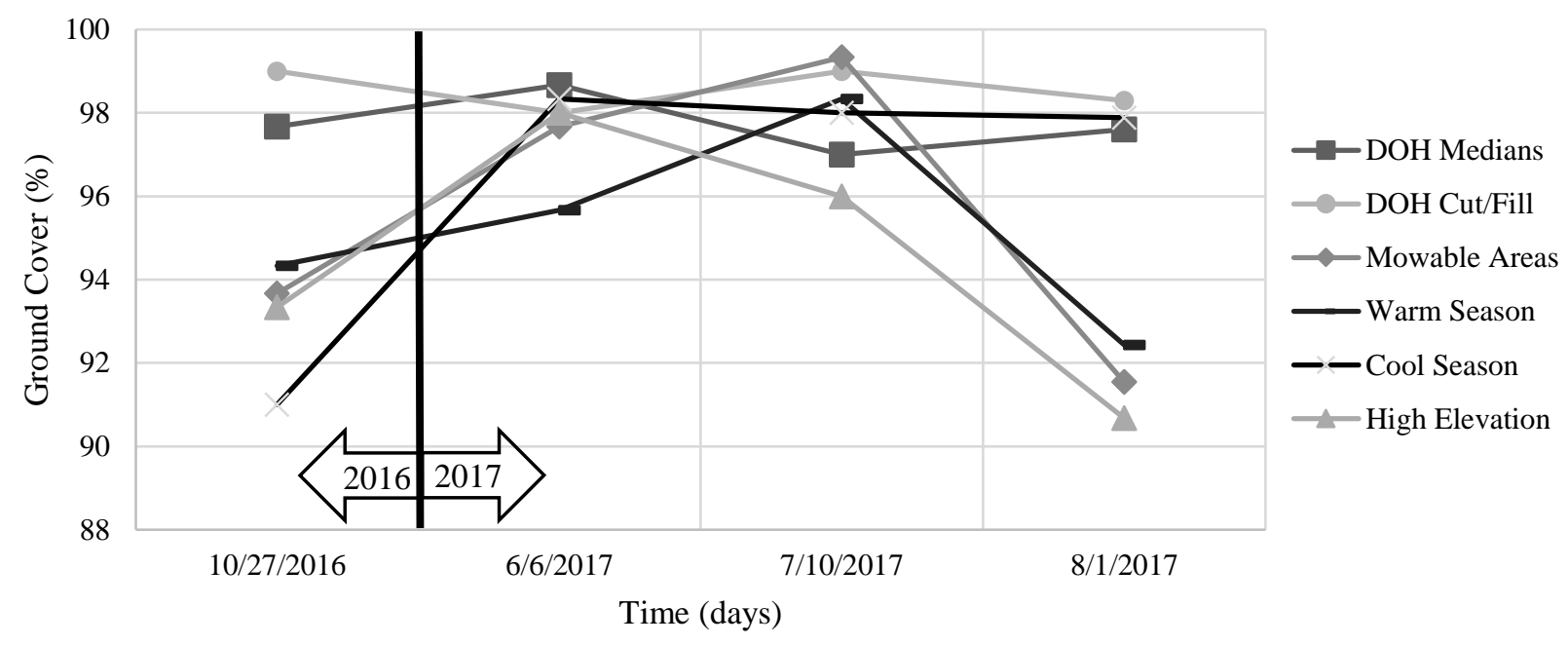

Figure 12: CH-1A third growing season average ground cover (2017)

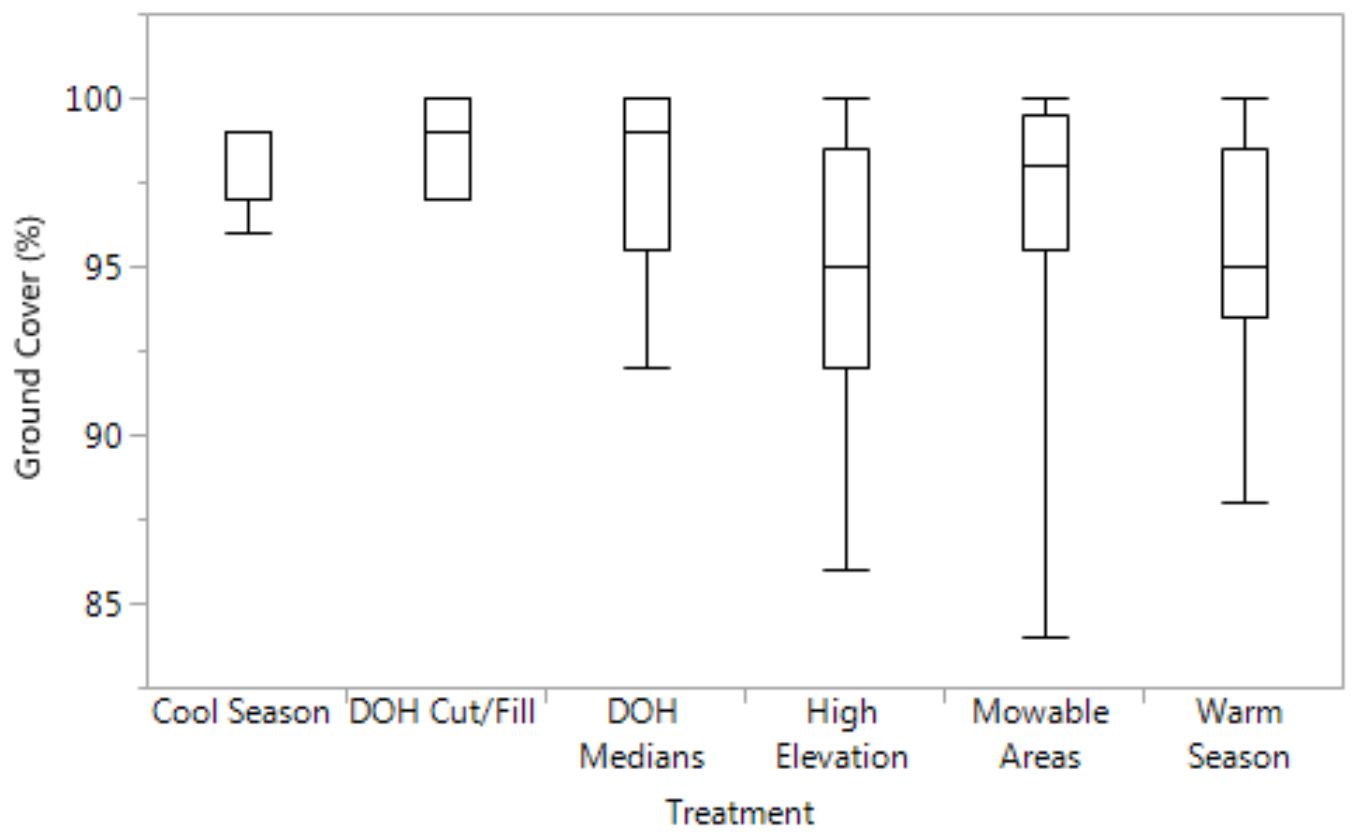

Figure 13: CH-1A distribution of ground cover for seed mixtures: cool season, DOH cut/fill, DOH medians, high elevation, mowable areas, and warm season; median (—); 25-75\% (box); min and max (whisker) (2017)

Average ground cover by planted species in the third growing season (August 2017) was as follows: $76 \%$ in WVDOH Medians subplots, $93 \%$ in WVDOH cut/fill subplots, $40 \%$ in mowable areas subplots, $52 \%$ in warm season subplots, $97 \%$ in cool season subplots, and $23 \%$ in high elevation subplots. Subplots planted with experimental high elevation seed mixture had the most ground cover by species that were not contained in the mixture (Figure 14). Ground cover at subplots containing experimental high elevation and mowable areas mixtures was dominated by species that were not planted in the third growing season. Subplots planted with experimental 
warm season and both WVDOH mixtures resulted in the highest ground cover by graminoid species. Cool season subplot resulted in most ground cover by legume species (Table 4).

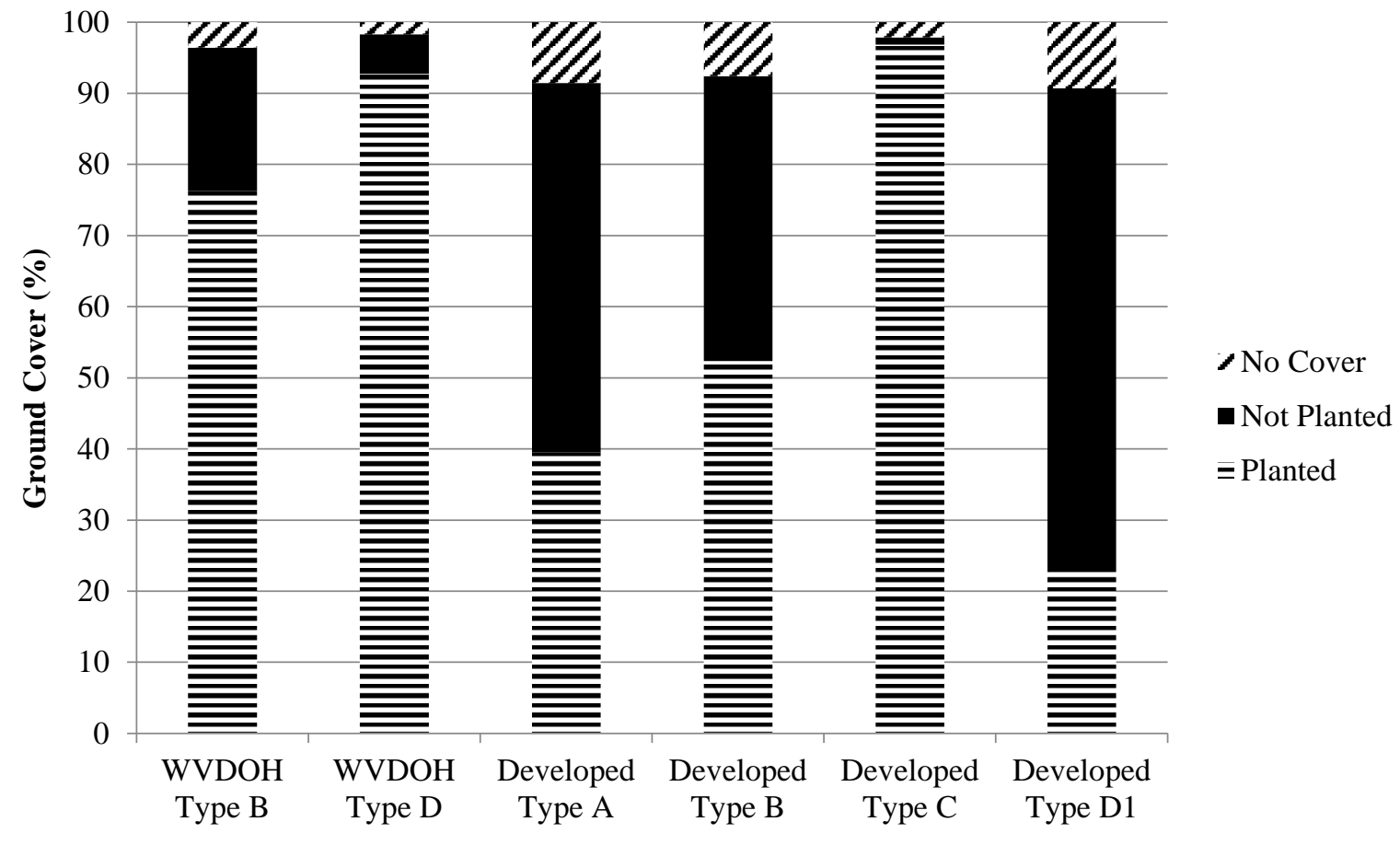

Figure 14: CH-1A average ground cover by species (August 2017)

Table 4: CH-1A average ground cover by area (August 2017)

\begin{tabular}{|c|c|c|c|c|c|}
\hline \multirow[t]{2}{*}{ Seed Mixture } & \multicolumn{5}{|c|}{ Composition of Mixture (\%) } \\
\hline & Forb & Legume & Graminoid & & \\
\hline Exp. Mowable Areas & 0.0 & 1.8 & 98.2 & & \\
\hline Exp. Warm Season & 2.9 & 1.4 & 95.7 & & \\
\hline Exp. Cool Season & 0.0 & 27.5 & 72.5 & & \\
\hline Exp. High Elevation & 3.6 & 1.6 & 94.8 & & \\
\hline DOH Medians & 0.0 & 3.3 & 96.7 & & \\
\hline \multirow[t]{3}{*}{ DOH Cut/Fill } & 0.0 & 31.7 & 68.3 & & \\
\hline & \multicolumn{5}{|c|}{ Ground Cover (\%) } \\
\hline & Forb & Legume & Graminoid & Not Planted & No Cover \\
\hline Exp. Mowable Areas & 0.0 & 0.0 & 39.5 & 52.0 & 8.5 \\
\hline Exp. Warm Season & 2.2 & 1.4 & 48.7 & 40.1 & 7.6 \\
\hline Exp. Cool Season & 0.0 & 93.0 & 3.9 & 1.1 & 2.1 \\
\hline Exp. High Elevation & 0.7 & 0.3 & 21.7 & 67.9 & 9.4 \\
\hline DOH Medians & 0.0 & 0.0 & 77.2 & 20.3 & 2.5 \\
\hline DOH Cut/Fill & 0.0 & 12.4 & 80.3 & 5.5 & 1.8 \\
\hline
\end{tabular}

Subplots containing experimental warm season and mowable areas mixtures contained the most total biomass and biomass from species that were not planted of all subplots in the third growing 
season. Experimental cool season subplots contained the least biomass from species that were not planted. Subplots planted with WVDOH medians mixture resulted in the most biomass from species that were not planted (Figure 15). Dunn method test results indicated that there was not a significant difference in total biomass produced by different seed mixtures ( $p$-value $\geq 1.0$ for all pairs) (Figure 16).

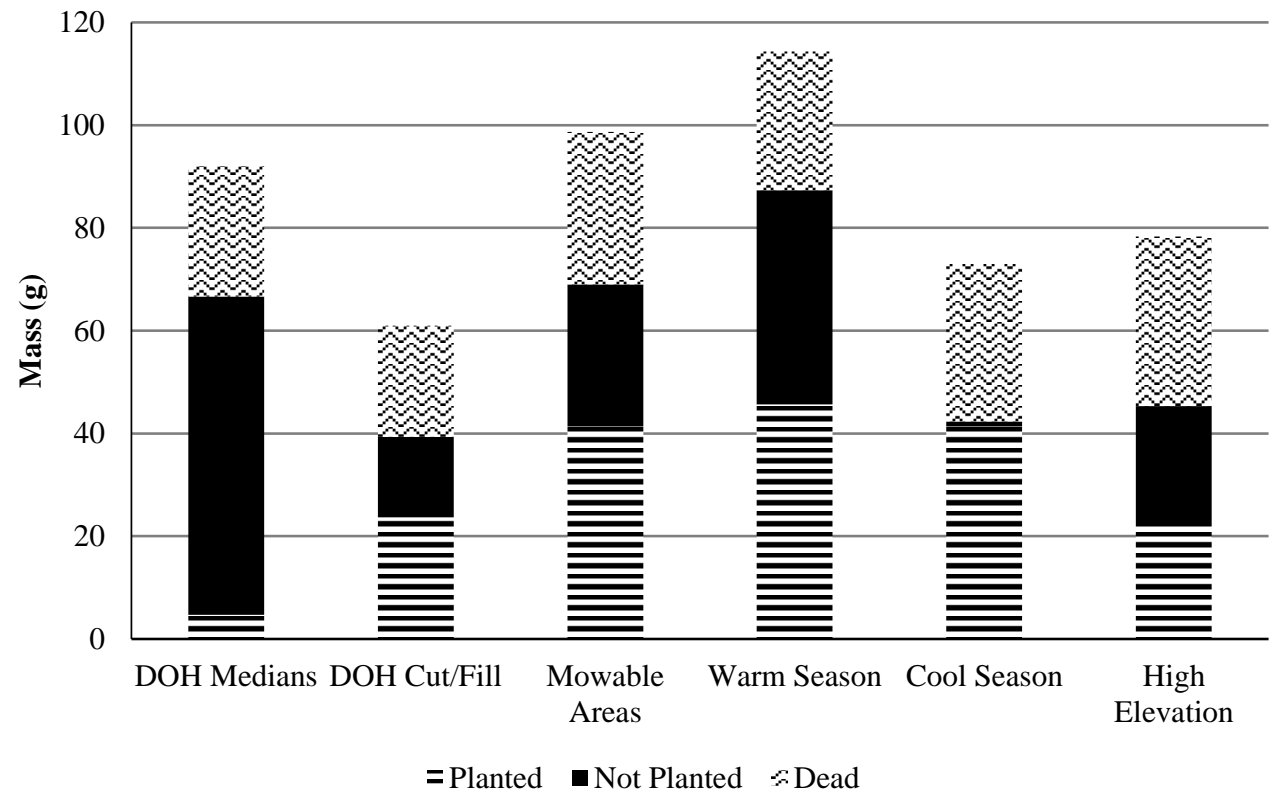

Figure 15: CH-1A total biomass weight (July 2017)

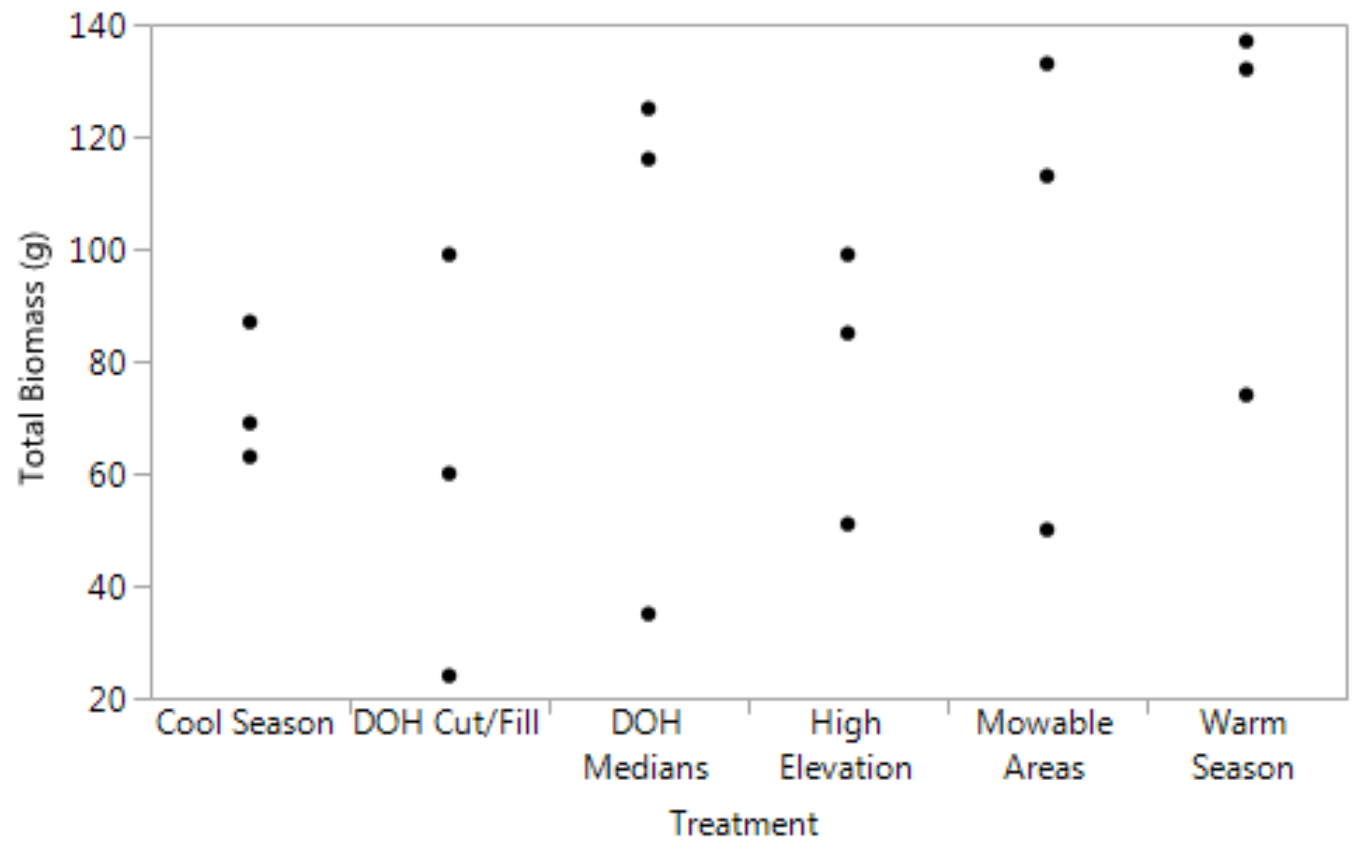

Figure 16: CH-1A distribution of biomass for six seed mixtures: cool season, DOH cut/fill, DOH medians, high elevation, mowable areas, and warm season (2017) 


\subsubsection{Soil}

Soil nutrients, organic matter, and $\mathrm{pH}$ increased considerably from before disturbance in May 2015 until the end of the second growing season in 2016. Organic matter almost doubled after vegetation establishment (Table 5).

Table 5: CH-1A end of season soil analysis

\begin{tabular}{llllll}
\hline Date & OM (\%) & $\mathbf{N}(\mathbf{p p m})$ & $\mathbf{K}(\mathbf{p p m})$ & $\mathbf{P}(\mathbf{p p m})$ & $\mathbf{p H}$ \\
\hline Before Disturbance & 1.5 & 2 & 117 & 4 & 7.3 \\
$10 / 27 / 2016$ & 2.8 & 12 & 160 & 45 & 7.6 \\
\hline
\end{tabular}

\subsubsection{CH-2: Testing Experimental High Elevation Seed Mixture}

\subsubsection{Temperature and Precipitation}

\section{Second Growing Season (2016):}

Average daily temperature peaked in late July at a value of $78.8^{\circ} \mathrm{F}\left(26^{\circ} \mathrm{C}\right)$. Total precipitation for the entire growing season was 11.6 in $(29.5 \mathrm{~cm})$. Drought periods occurred in mid-late July and mid-late August. Precipitation totals in June through October were 1.30 in $(3.30 \mathrm{~cm}), 5.14$ in $(13.1 \mathrm{~cm}), 0.52$ in $(1.32 \mathrm{~cm}), 3.15$ in $(8.00 \mathrm{~cm})$, and 1.49 in $(3.78 \mathrm{~cm})$, respectively. The highest precipitation accumulation in one day was 2.01 in $(5.11 \mathrm{~cm})$ and occurred on September 30 (Figure 17). 


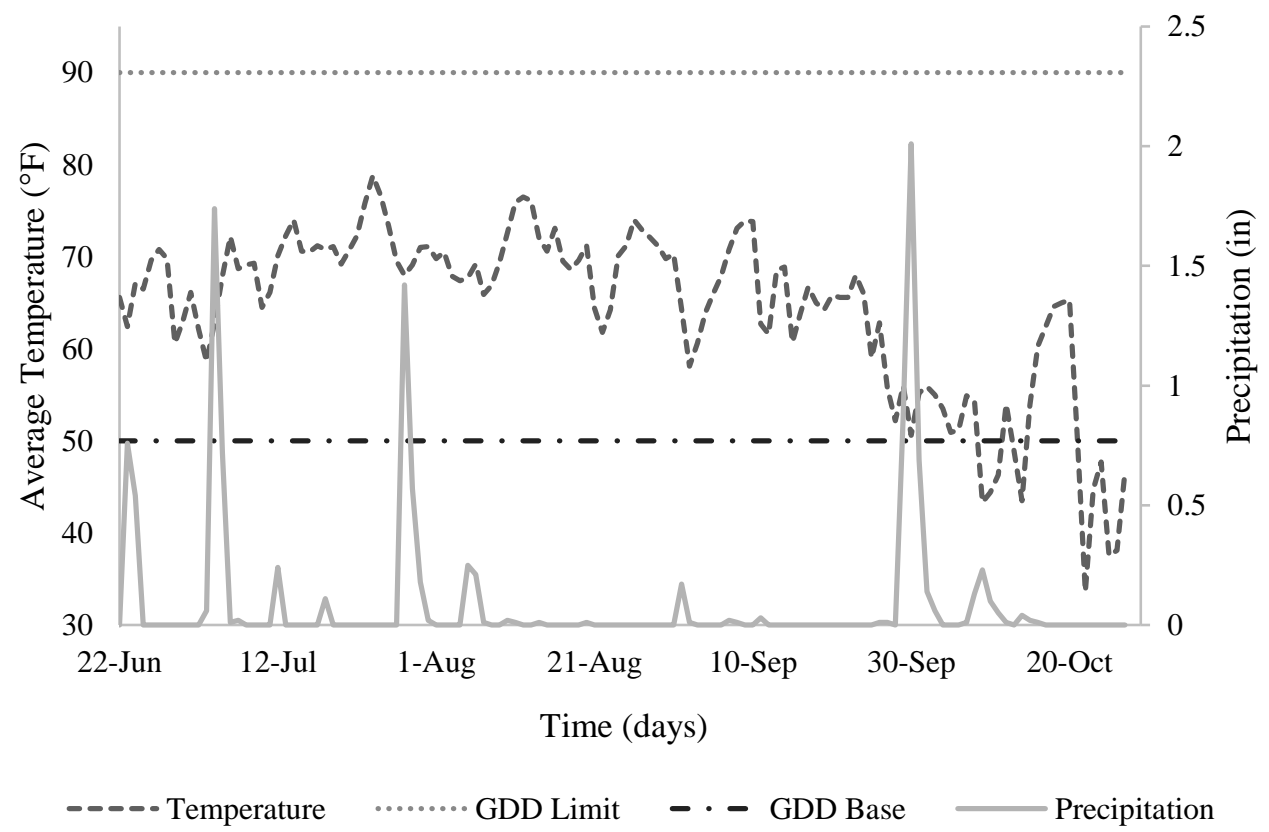

Figure 17: CH-2 distribution of air temperature and precipitation for the second growing season (JuneOctober 2016)

\section{Third Growing Season (2017):}

Precipitation accumulation was 0.02 in $(0.05 \mathrm{~cm})$ in June and 1.01 in $(2.57 \mathrm{~cm})$ in July. The highest daily precipitation was 0.15 in $(0.38 \mathrm{~cm})$ and occurred on July 6 . Mean temperatures for June and July were $64.9^{\circ} \mathrm{F}\left(18.28^{\circ} \mathrm{C}\right)$ and $68.2^{\circ} \mathrm{F}\left(20.1^{\circ} \mathrm{C}\right)$, respectively. 


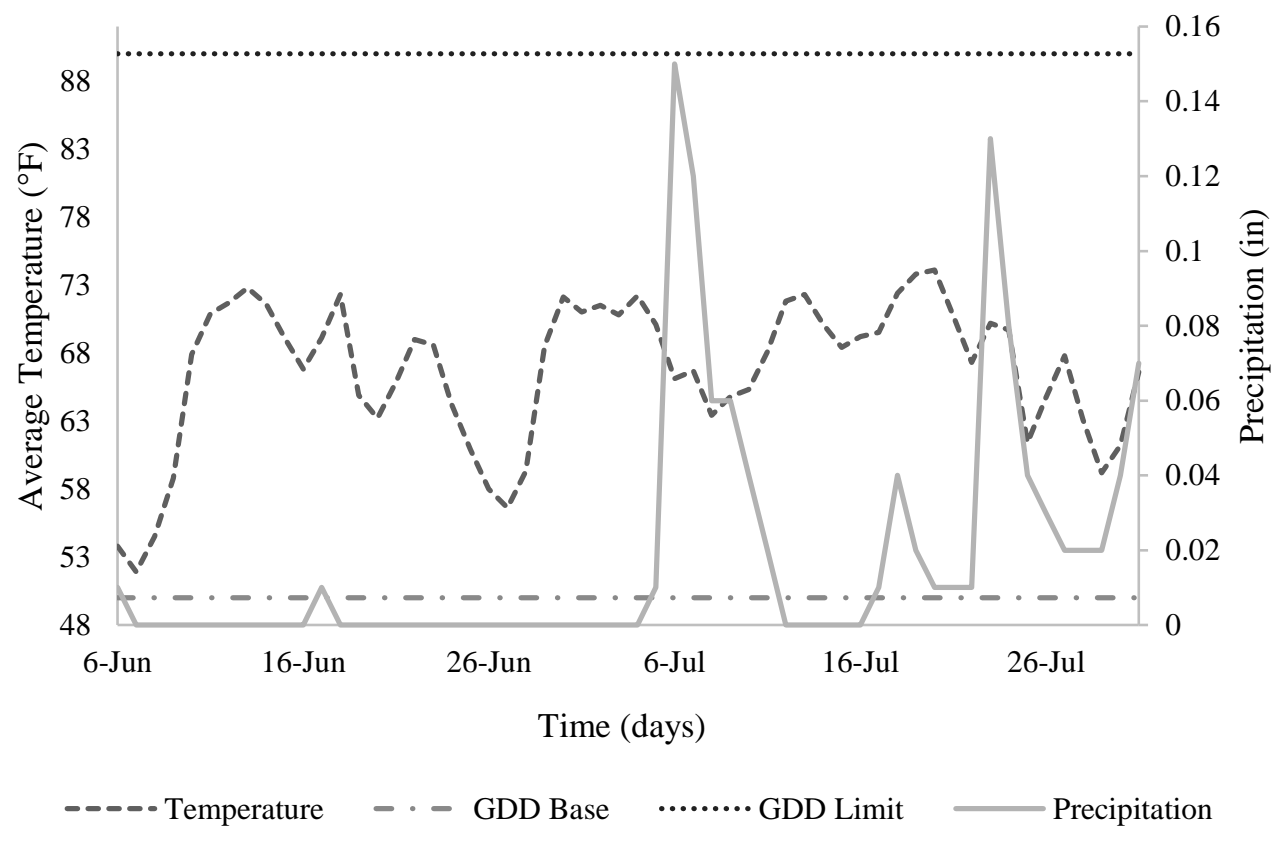

Figure 18: CH-2 distribution of air temperature and precipitation for the third growing season (June-July 2017)

\subsubsection{Vegetation}

\section{Second Growing Season (2016):}

Percent ground cover decreased below $70 \%$ in subplots containing high elevation and warm season mixtures during the middle of the season, but the entire plot resulted in greater than $75 \%$ ground cover by the end of the growing season (Figure 19). Kruskal-Wallis test indicated significant differences in ground cover of at least two seed mixtures (p-value $=0.0001$ ). Dunn's test indicated that statistically significant differences in ground cover existed between the following seed mixtures: high elevation and mowable areas ( $\mathrm{p}$-value $=0.0093$ ), high elevation and cool season $(\mathrm{p}$-value $=0.0023)$, and high elevation and WVDOH medians ( $\mathrm{p}$-value $=$ 0.0001) (Figure 20). 


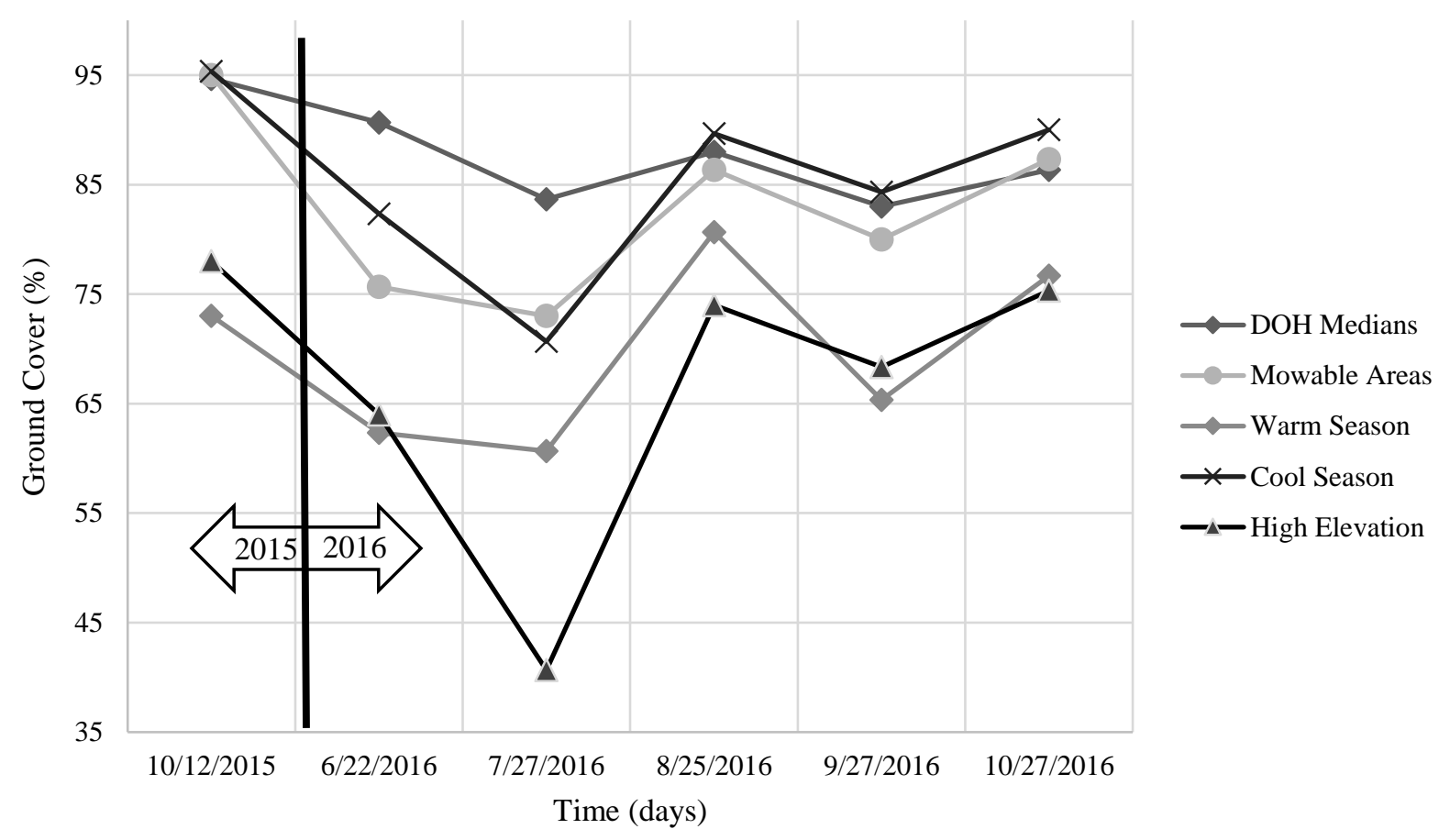

Figure 19: CH-2 second growing season average percent ground cover (2016) 


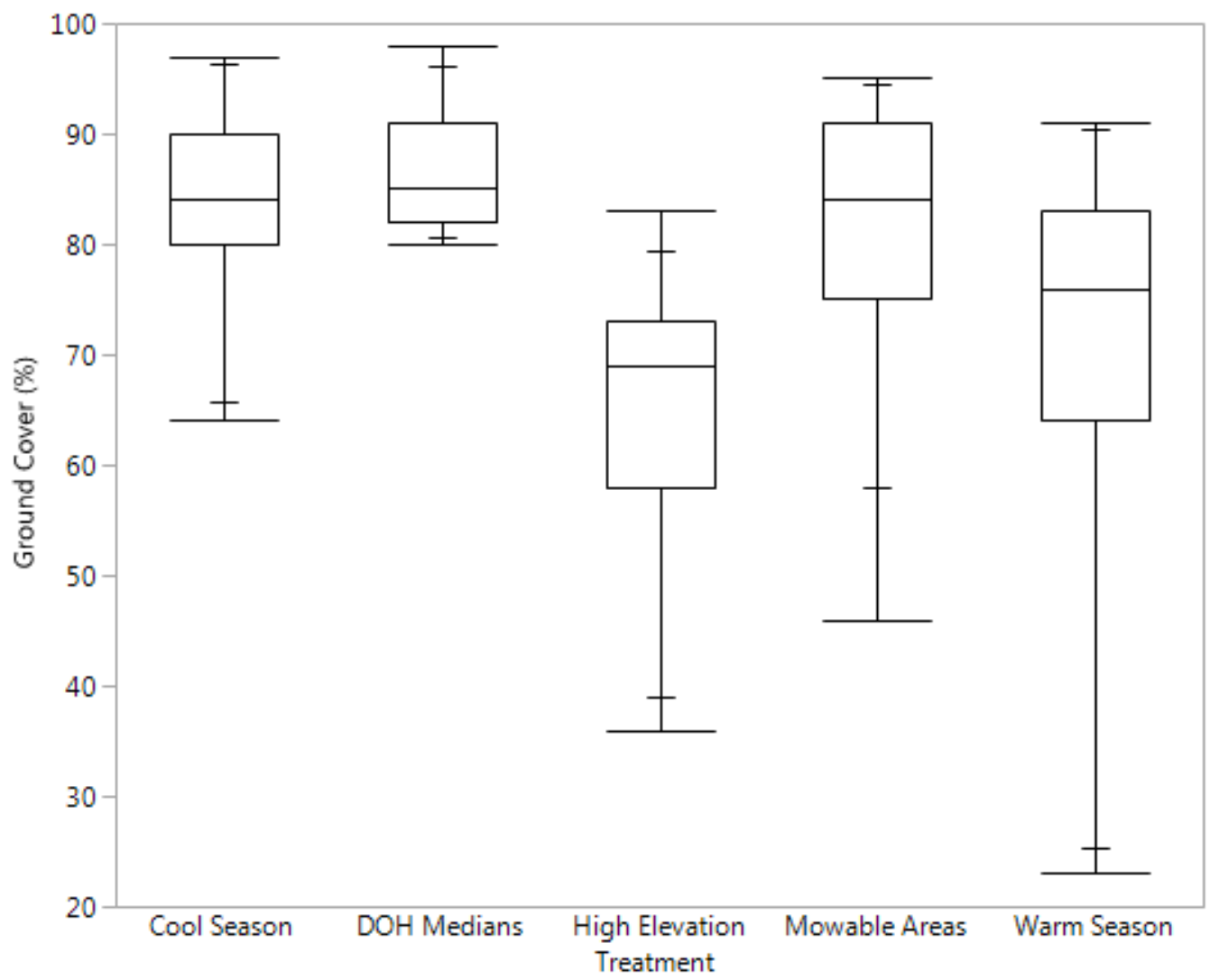

Figure 20: CH-2 distribution of ground cover for five seed mixtures: cool season, DOH medians, high elevation, mowable areas, and warm season; median (-); 25-75\% (box); $90 \%$ and $10 \%(-)$; min and max (whisker) (2016)

Experimental cool season mixtures had the highest average percentage of planted species at $87 \%$. This was followed closely by experimental mowable areas mixture, which had an average of $85 \%$ planted species cover. High elevation seed mixtures had the highest percentage of species that were not planted. 


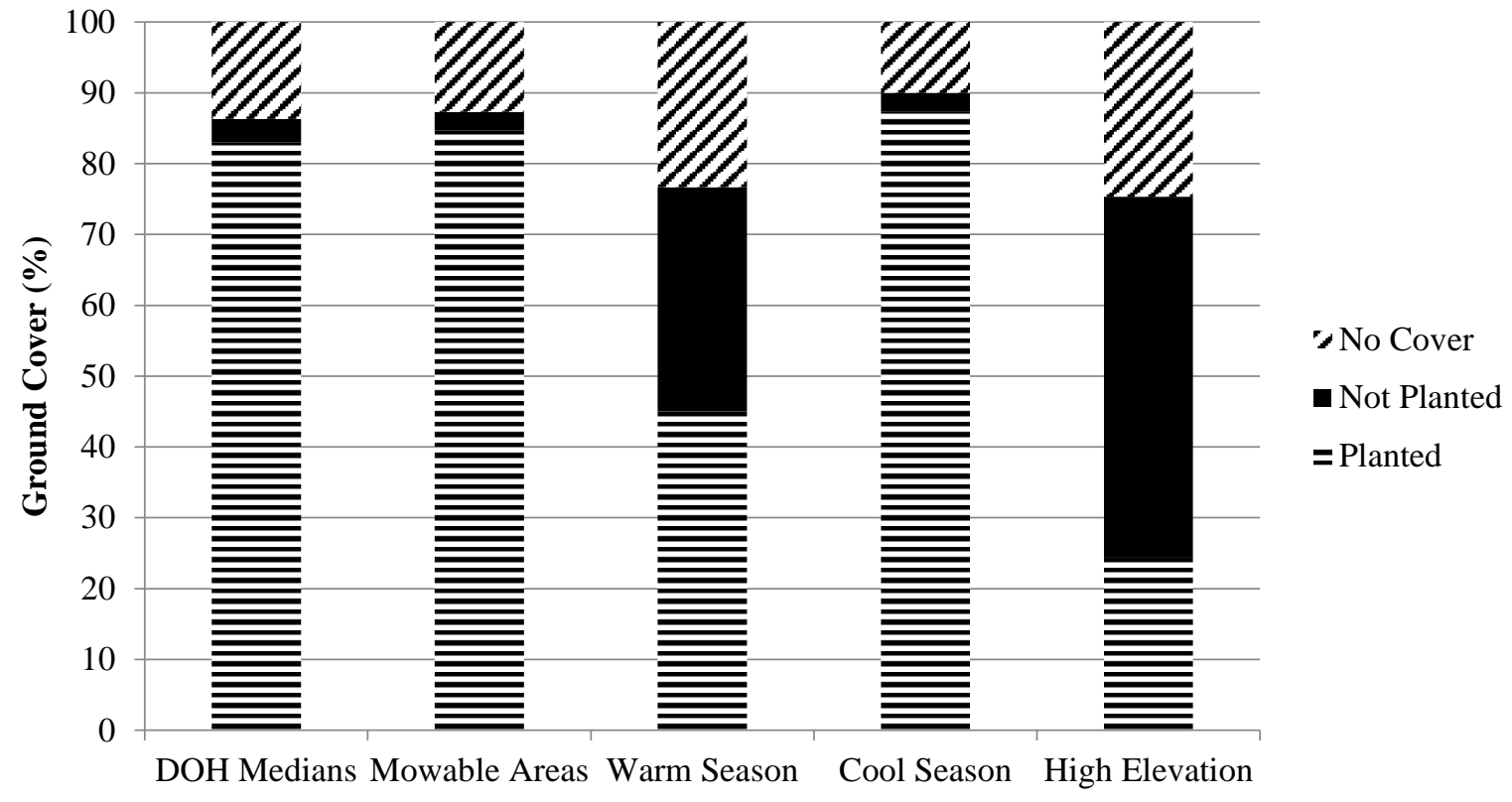

Figure 21: CH-2 average ground cover by species (October 2016)

Ground cover in subplots planted with high elevation mixtures was dominated by species that were not planted at the end of the season. Ground cover in all other subplots consisted mostly of graminoids. Experimental cool season mixture subplots resulted in the greatest legume ground cover in the entire plot $(27.5 \%)$. White clover ground cover in subplots containing mowable areas mixtures was much higher than the percent of white clover composing the seed mixture at planting (22.3\% ground cover compared to $2.2 \%$ mixture composition). High elevation and warm season mixture subplots resulted in some ground cover by forbs $(3.6 \%$ and $2.9 \%$, respectively). Differences between percent ground cover by vegetation types at the end of the season and percent composition by vegetation types of the mixture mostly existed due to bare ground and invasion of weed species into the plot (Table 6). 
Table 6: CH-2: average ground cover by area (October 2016)

\begin{tabular}{|c|c|c|c|c|c|}
\hline \multirow[t]{2}{*}{ Seed Mixture } & \multicolumn{5}{|c|}{ Composition of Mixture (\%) } \\
\hline & Forb & Legume & Graminoid & & \\
\hline Exp. Mowable Areas & 0.0 & 1.8 & 98.2 & & \\
\hline Exp. Warm Season & 2.9 & 1.4 & 95.7 & & \\
\hline Exp. Cool Season & 0.0 & 27.5 & 72.5 & & \\
\hline Exp. High Elevation & 3.6 & 1.6 & 94.8 & & \\
\hline \multirow[t]{3}{*}{ DOH Medians } & 0.0 & 3.3 & 96.7 & & \\
\hline & \multicolumn{5}{|c|}{ Ground Cover (\%) } \\
\hline & Forb & Legume & Graminoid & Not Planted & No Cover \\
\hline Exp. Mowable Areas & 0.0 & 22.3 & 62.3 & 2.7 & 12.7 \\
\hline Exp. Warm Season & 1.0 & 0.0 & 44.0 & 31.7 & 23.3 \\
\hline Exp. Cool Season & 0.0 & 12.3 & 75.0 & 2.7 & 10.0 \\
\hline Exp. High Elevation & 1.3 & 0.0 & 23.0 & 51.0 & 24.7 \\
\hline DOH Medians & 0.0 & 5.0 & 78.0 & 3.3 & 13.7 \\
\hline
\end{tabular}

Subplots containing cool season mixtures produced the highest total biomass. This was followed by subplots planted with WVDOH median and mowable areas mixtures. Warm season and high elevation mixture subplots contained the most biomass of species that were not planted (Figure 22). Dunn's test results indicated no significant differences in biomass between any pairs of seed mixtures (Figure 23). 


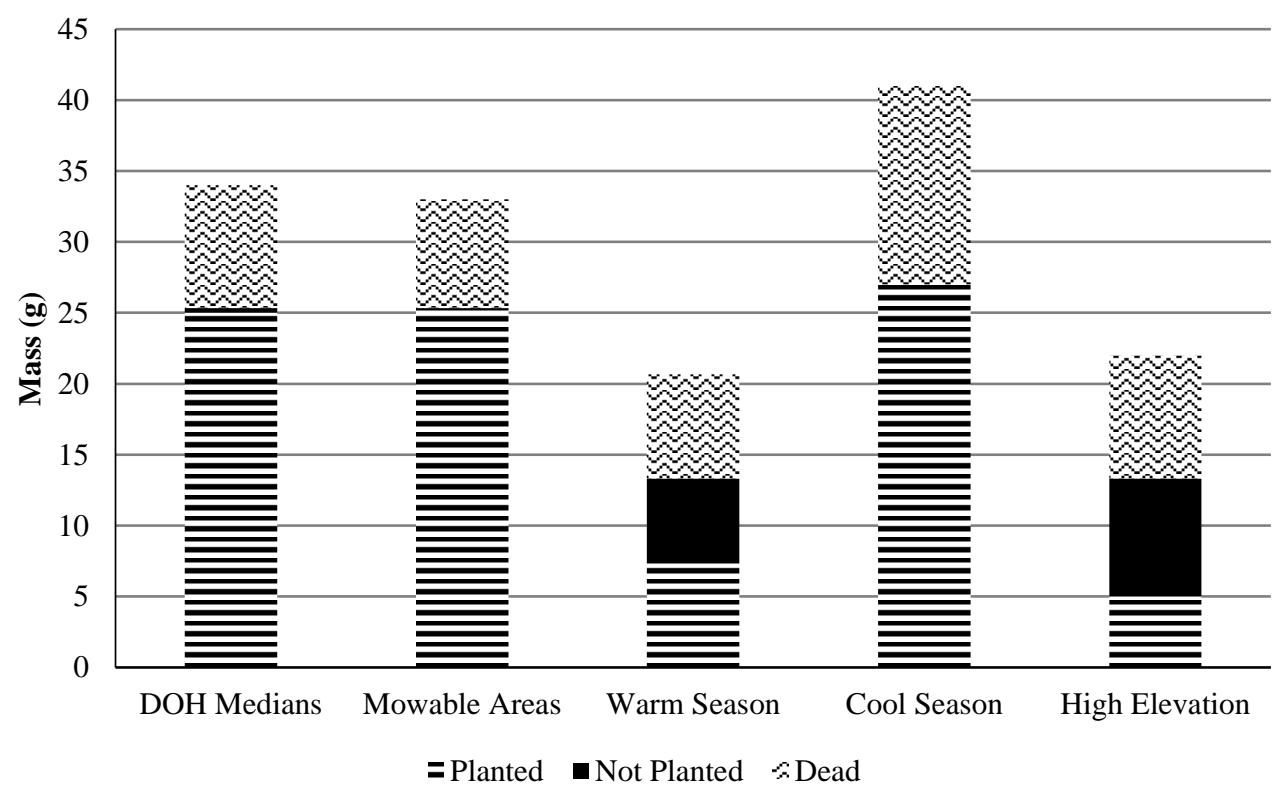

Figure 22: CH-2 total biomass weight (October 2016)

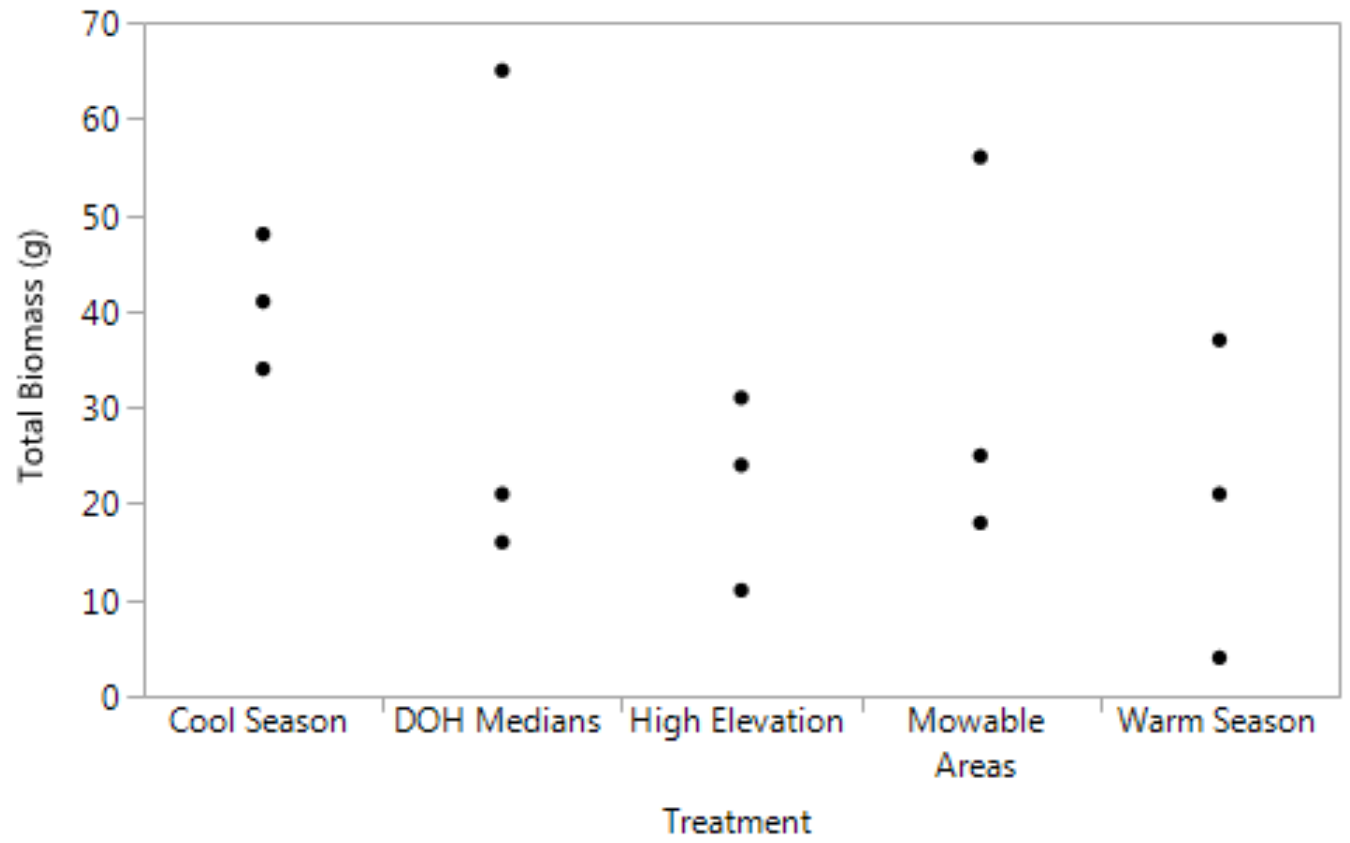

Figure 23: CH-2 distribution of biomass for five seed mixtures: cool season, DOH medians, high elevation, mowable areas, and warm season (2016)

\section{Third Growing Season (2017):}

All subplots except ones planted with high elevation seed mixture remained above $70 \%$ ground cover on average during the third growing season. Subplots containing DOH medians and cool season mixtures resulted in the highest average ground cover throughout the entire season (Figure 24). Kruskal-Wallis test results indicated significant differences between percent ground 
cover of at least two seed mixtures ( $\mathrm{p}$-value $=0.0009$ ). Dunn's test results specified differences in ground cover between subplots planted with experimental high elevation and WVDOH medians mixtures (Figure 25).

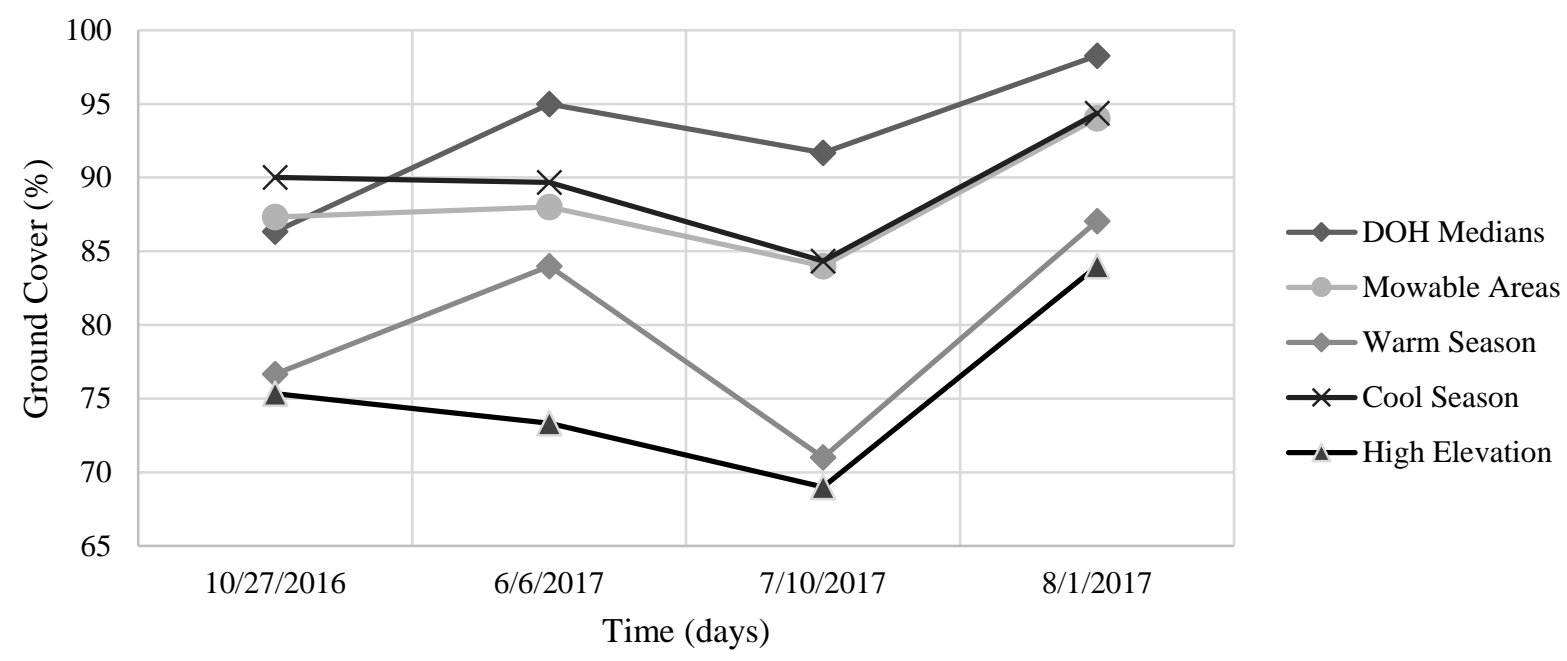

Figure 24: $\mathrm{CH}-2$ third growing season average percent ground cover (2017)

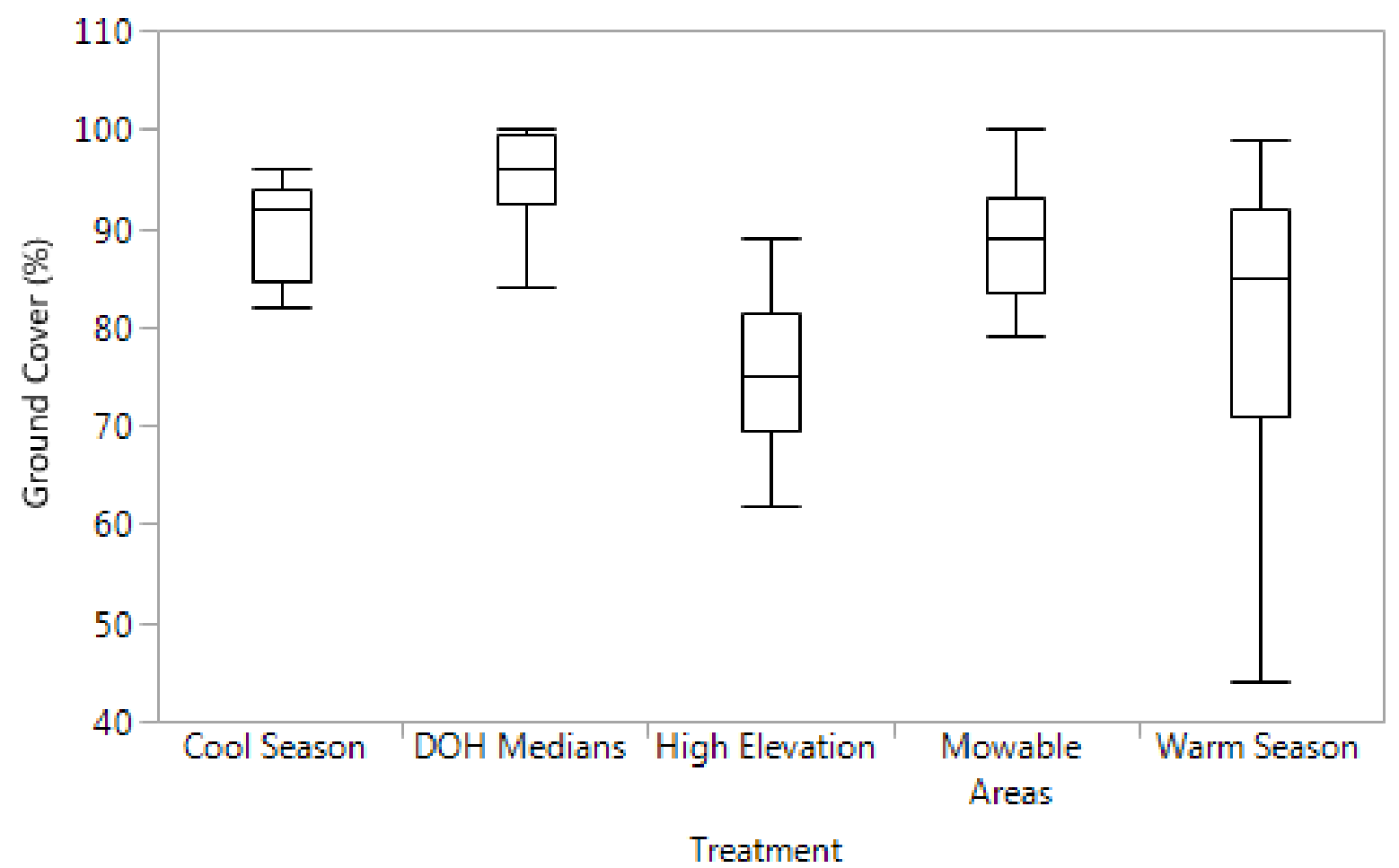

Figure 25: CH-2 distribution of ground cover for five seed mixtures: cool season, DOH medians, high elevation, mowable areas, and warm season; median (—); 25-75\% (box); min and max (whisker) (2017)

Subplots planted with experimental high elevation and warm season mixtures contained the most ground cover by species not contained in the mixture than subplots planted with any other 
mixture during the third growing season. Subplots containing WVDOH medians and experimental mowable areas mixtures resulted in the highest ground cover by planted species (92\% and 88\%, respectively) (Figure 26). Ground cover in all subplots resulted in mostly graminoid species. Subplots planted with experimental mowable areas and cool season mixtures also contained $15.5 \%$ and $24.9 \%$ ground cover by legume species, respectively (Table 7 ).

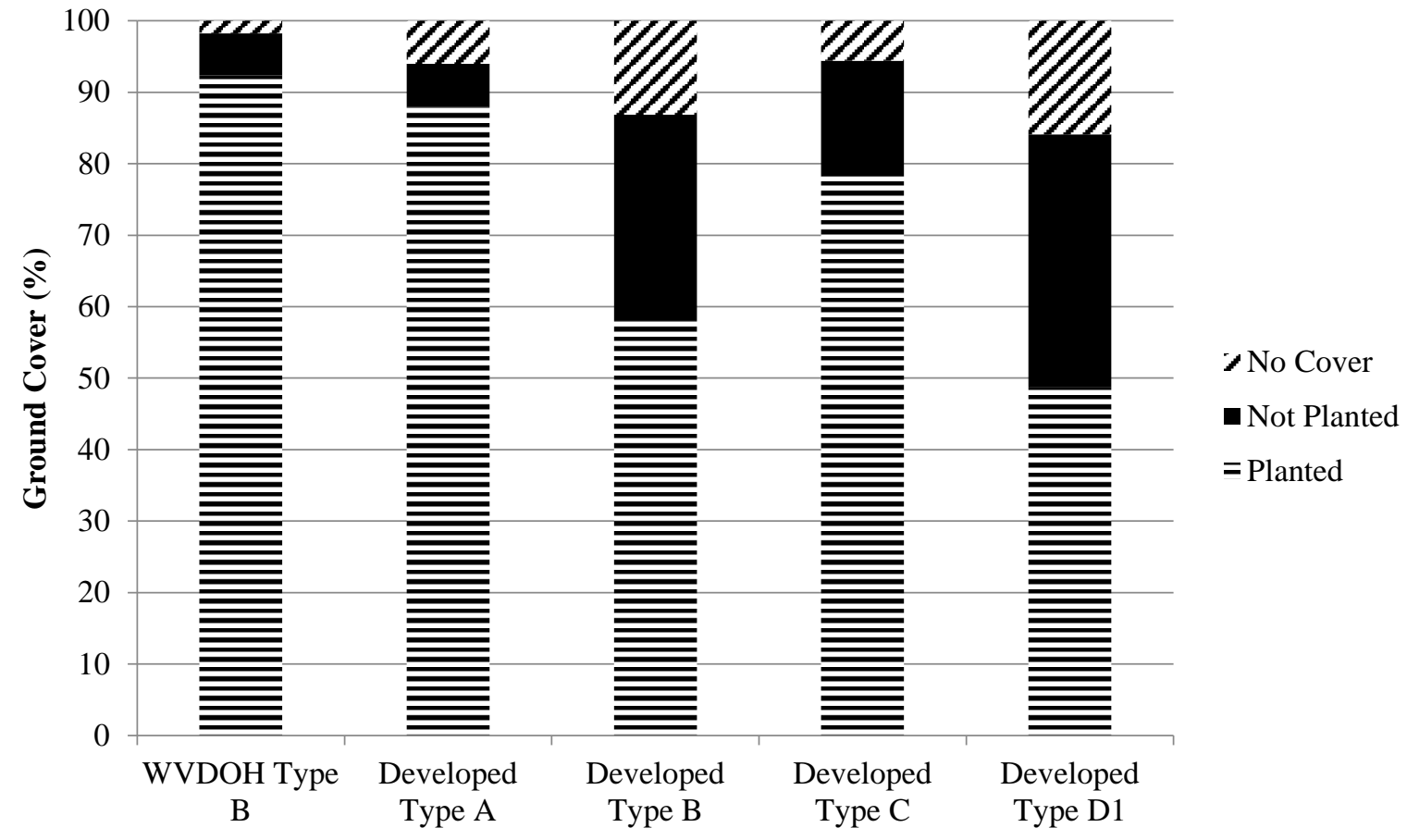

Figure 26: CH-2 average ground cover by species (August 2017) 
Table 7: CH-2: average ground cover by area (August 2017)

\begin{tabular}{|c|c|c|c|c|c|}
\hline \multirow[t]{2}{*}{ Seed Mixture } & \multicolumn{5}{|c|}{ Composition of Mixture (\%) } \\
\hline & Forb & Legume & Graminoid & & \\
\hline Exp. Mowable Areas & 0.0 & 1.8 & 98.2 & & \\
\hline Exp. Warm Season & 2.9 & 1.4 & 95.7 & & \\
\hline Exp. Cool Season & 0.0 & 27.5 & 72.5 & & \\
\hline Exp. High Elevation & 3.6 & 1.6 & 94.8 & & \\
\hline \multirow[t]{3}{*}{ DOH Medians } & 0.0 & 3.3 & 96.7 & & \\
\hline & \multicolumn{5}{|c|}{ Ground Cover (\%) } \\
\hline & Forb & Legume & Graminoid & Not Planted & No Cover \\
\hline Exp. Mowable Areas & 0.0 & 15.5 & 72.4 & 6.0 & 6.1 \\
\hline Exp. Warm Season & 3.1 & 0.0 & 55.0 & 28.7 & 13.2 \\
\hline Exp. Cool Season & 0.0 & 24.9 & 53.3 & 16.1 & 5.7 \\
\hline Exp. High Elevation & 1.4 & 0.0 & 47.3 & 35.3 & 16.0 \\
\hline DOH Medians & 0.0 & 0.7 & 91.6 & 5.9 & 1.8 \\
\hline
\end{tabular}

Subplots containing experimental mowable areas mixtures produced the most total biomass during the third growing season. This was followed closely by subplots planted with experimental warm season mixtures, which also produced the most biomass from species that were not planted. High elevation mixture subplots resulted in the least total biomass (Figure 27). Dunn's test resulted in p-values of 1.0 or greater for all pairs of seed mixtures, which indicates that there were no significant differences in total biomass of different seed mixtures (Figure 28).

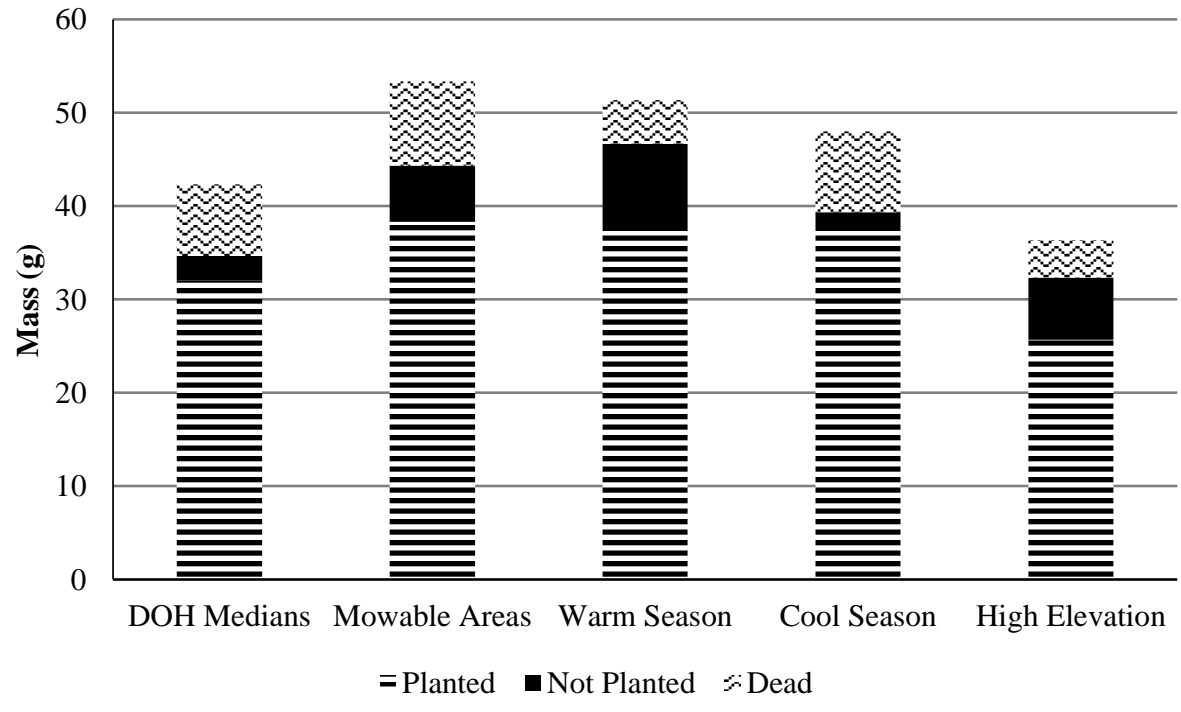

Figure 27: CH-2 total biomass weight (July 2017) 


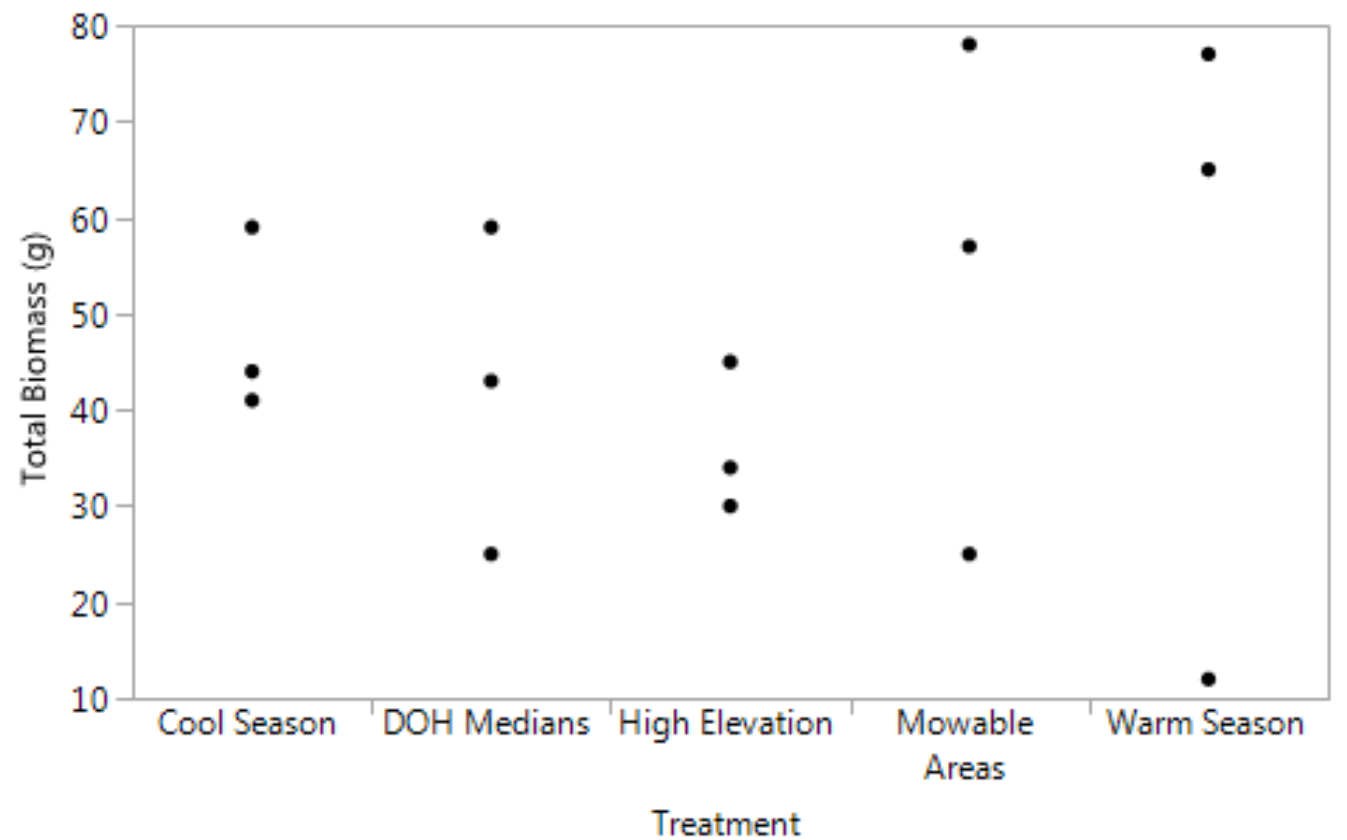

Figure 28: CH-2 distribution of biomass for five seed mixtures: cool season, DOH medians, high elevation, mowable areas, and warm season (2017)

\subsubsection{Soil}

Organic matter decreased by approximately $1 \%$ from before disturbance conditions until the end of the second growing season. Nitrogen, phosphorus, calcium, sulfur, and magnesium increased while potassium decreased. Soil $\mathrm{pH}$ increased considerably after vegetation establishment (Table 8).

Table 8: CH-2 end of season soil analysis results

\begin{tabular}{llllll}
\hline Date & OM (\%) & N (ppm) & K $(\mathbf{p p m})$ & $\mathbf{P}(\mathbf{p p m})$ & $\mathbf{p H}$ \\
\hline Before Disturbance & 2.7 & 2 & 113 & 4 & 6.4 \\
$10 / 27 / 2016$ & 1.6 & 2 & 110 & 9 & 7.6 \\
\hline
\end{tabular}

\subsubsection{CH-3: Testing Seed Bed Preparation Techniques}

\subsubsection{Temperature and Precipitation}

\section{Second Growing Season (2016):}

Total precipitation during the entire growing season was 16.0 in $(40.6 \mathrm{~cm})$. Between August 11 and September 28, the plot experienced only 1.54 in $(3.91 \mathrm{~cm})$ of total rain. Following this drought period, the highest daily precipitation amount measured at 4.34 in $(11.02 \mathrm{~cm})$ on September 29. The total precipitation amount for June through October was 2.31 in $(5.87 \mathrm{~cm})$, 3.74 in $(9.50 \mathrm{~cm}), 2.91$ in $(7.39 \mathrm{~cm}), 5.76$ in $(14.6 \mathrm{~cm})$, and 1.28 in $(3.25 \mathrm{~cm})$. The highest mean temperature recorded was $84.4^{\circ} \mathrm{F}\left(29.1^{\circ} \mathrm{C}\right)$ on July 24 (Figure 29). 


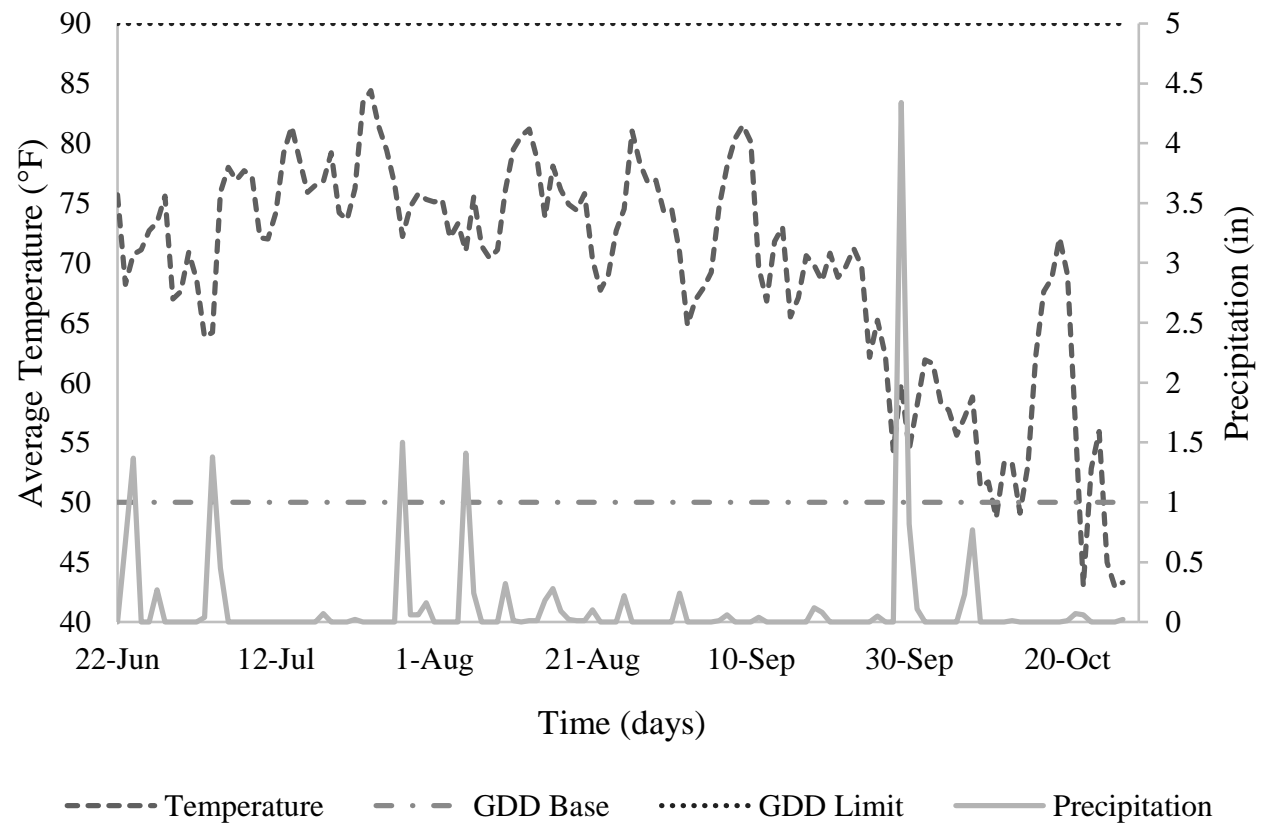

Figure 29: CH-3 distribution of air temperature and precipitation for the second growing season (JuneOctober 2016)

\section{Third Growing Season (2017):}

Average temperatures in June and July were $70.5^{\circ} \mathrm{F}\left(21.4^{\circ} \mathrm{C}\right)$ and $73.9^{\circ} \mathrm{F}\left(23.3^{\circ} \mathrm{C}\right)$, respectively. Twelve days of rainfall in June accumulated 3.47 in $(8.81 \mathrm{~cm})$ of precipitation. July also had 12 rain days that had a total precipitation of 7.06 in $(17.93 \mathrm{~cm})$. The highest daily precipitation was 2.56 in $(6.50 \mathrm{~cm})$ and occurred on July 28 . 


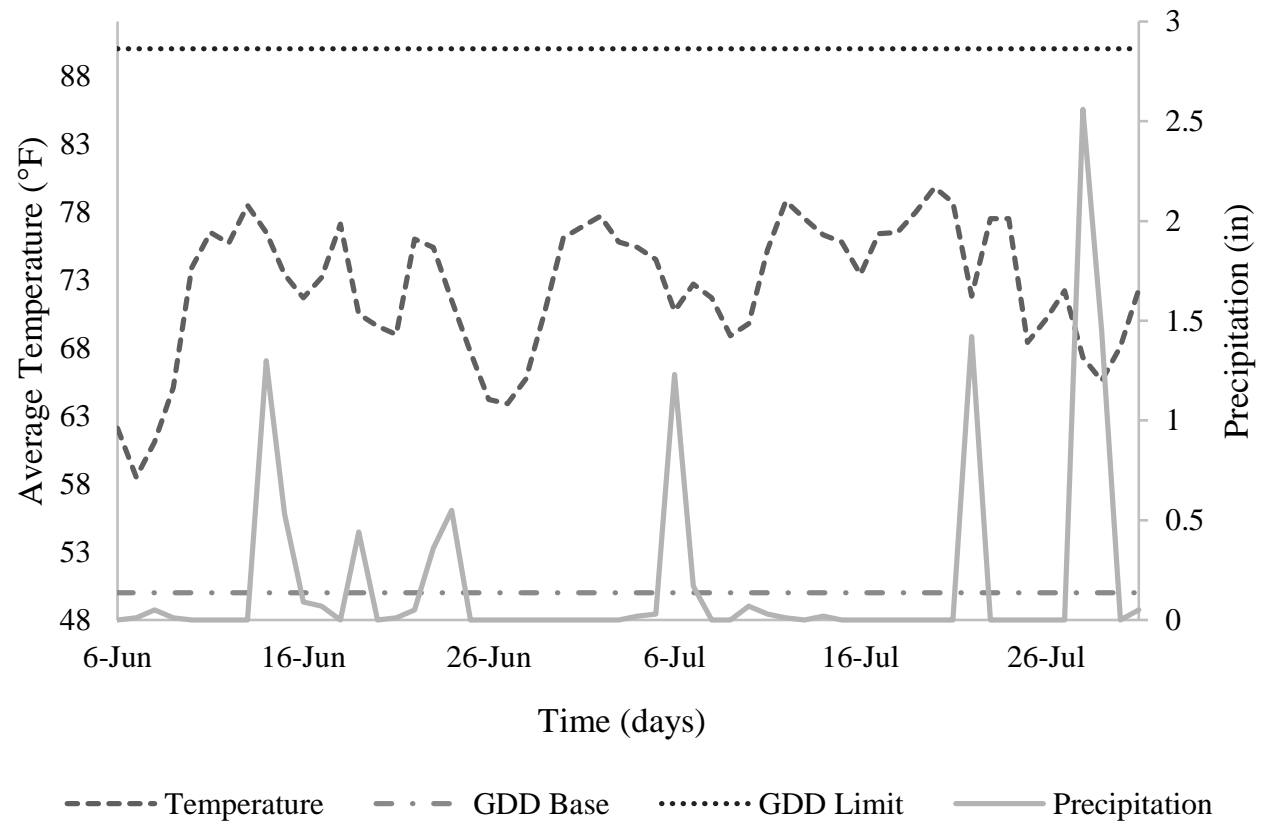

Figure 30: CH-3 distribution of air temperature and precipitation for the third growing season (June-July 2017)

\subsubsection{Vegetation}

\section{Second Growing Season (2106):}

Percent ground cover remained above $75 \%$ across the entire plot during the entire second growing season. Aside from subplots containing experimental cool season seed mixtures, all other subplots showed a slight decrease in ground cover from the first to the second growing season. Standard deviation indicated the most variation in ground cover throughout the season in seed beds containing cool season mixtures planted in existing soil using hydraulic erosion control product (Figure 31). 


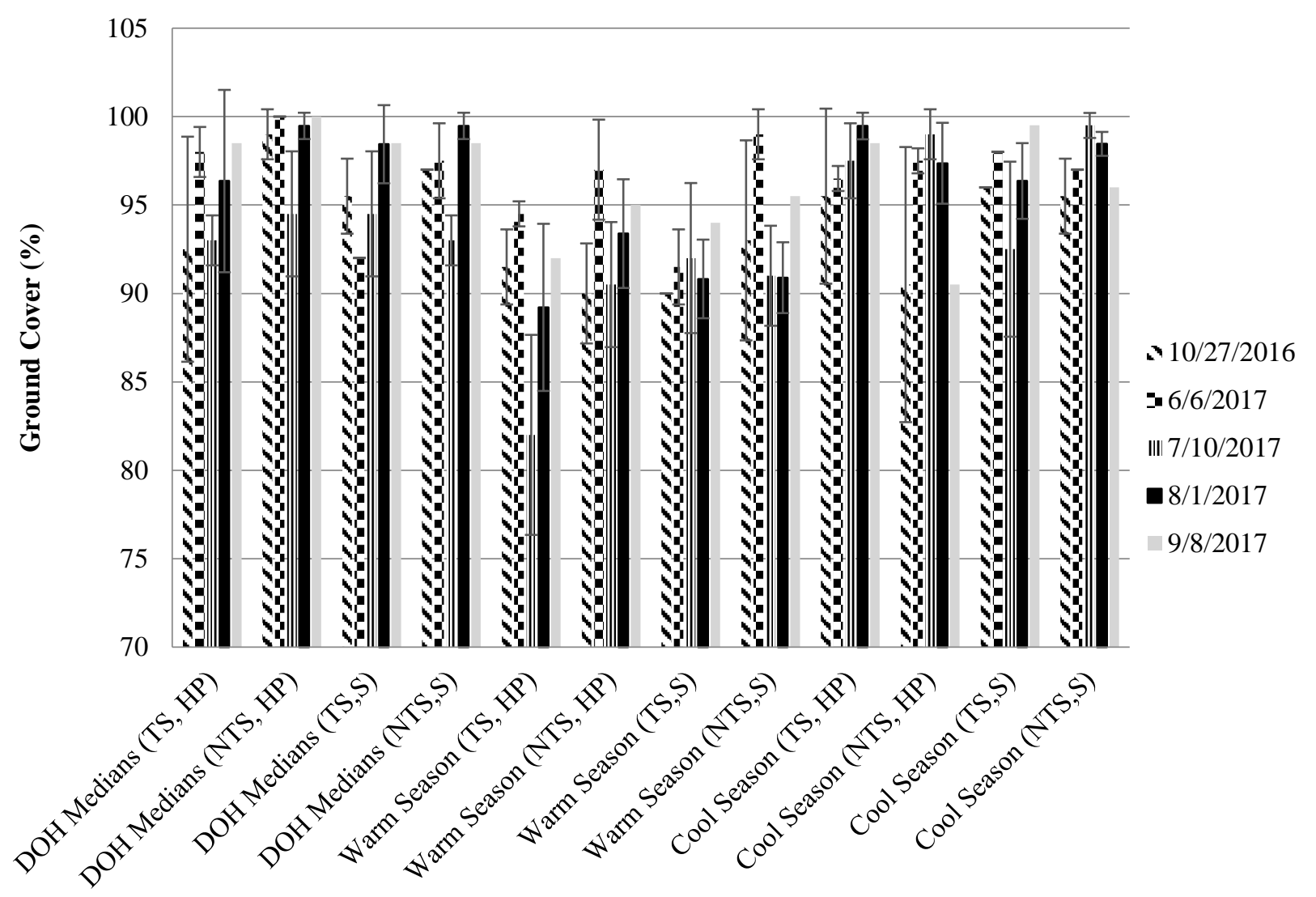

Figure 31: CH-3 second growing season average percent ground cover; error bars denote standard deviation (2016)

Ground cover in subplots planted with WVDOH mowable areas and experimental cool season mixtures performed higher on average than experimental warm season mixtures. All subplots resulted in ground cover greater than $85 \%$ on average during the entire season (Figure 32). There was no substantial difference with respect to ground cover between subplots established using straw mulch and HECP (Figure 33). 


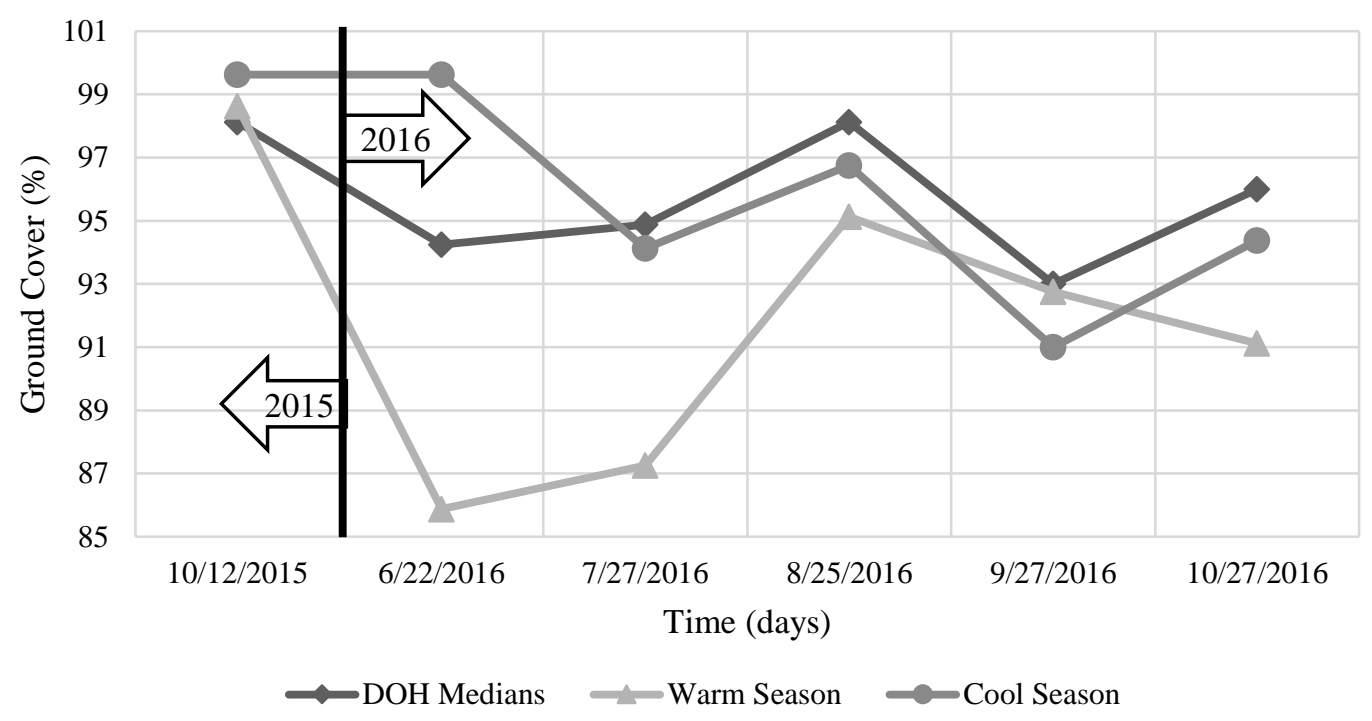

Figure 32: CH-3 second growing season average percent ground cover by seed mixture (2016)

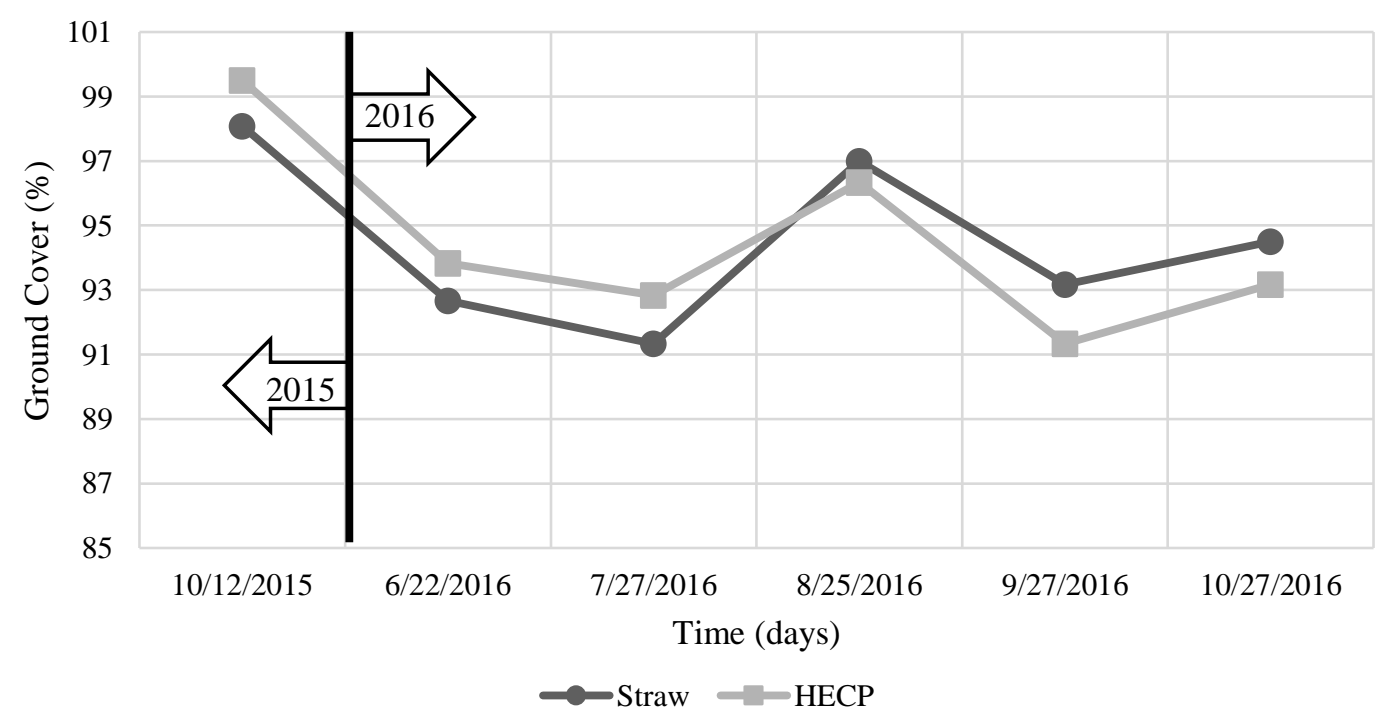

Figure 33: CH-3 second growing season average percent ground cover by mulch (2016)

There was also no considerable difference in percent ground cover with respect to seed beds planted in topsoil and seed beds planted in existing soil (Figure 34). One-way blocked KruskalWallis test of seed bed treatments resulted in a p-value of 0.2414; there was no significant difference between ground cover of different seed bed preparation treatments (Figure 35). There were significant differences in ground cover with respect to seed mixtures indicated by KruskalWallis test $(p$-value $=0.0001)$. Dunn method test indicated differences between two pairs of seed mixtures: WVDOH medians and warm season $(\mathrm{p}$-value $=0.0001)$ and warm season and cool season $(\mathrm{p}$-value $=0.0001)$ (Figure 36). 


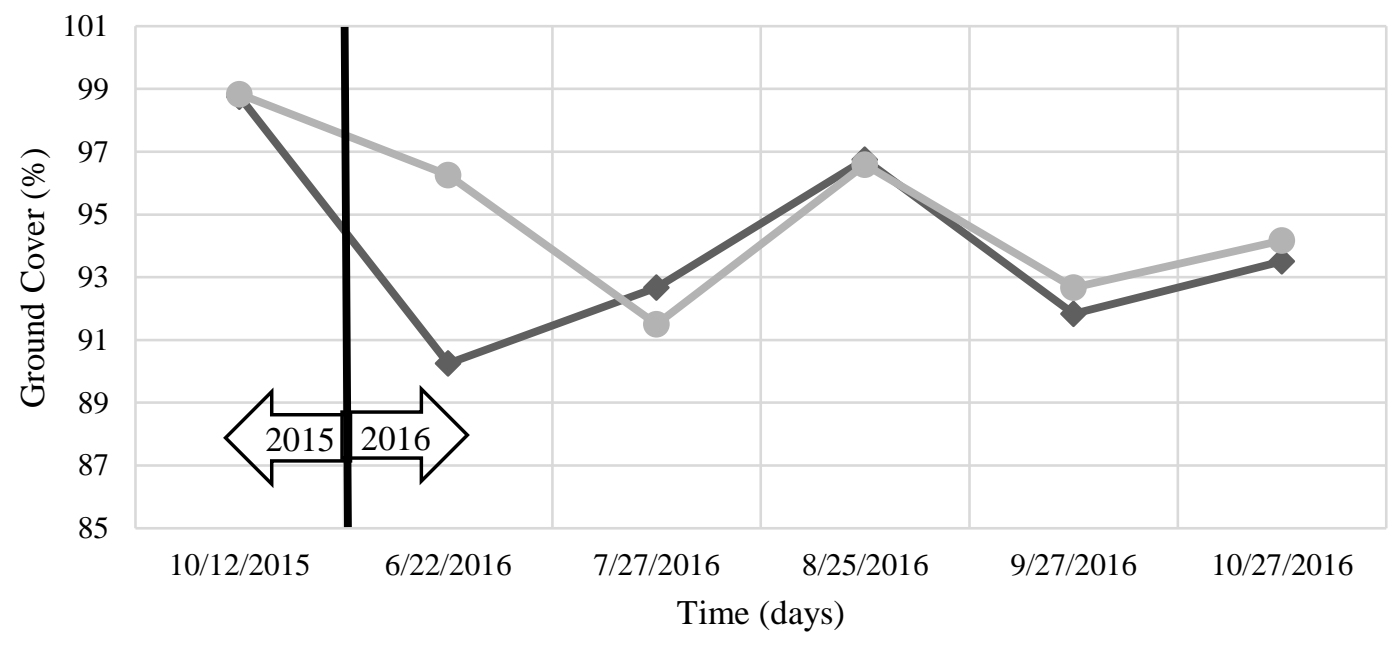

$\longrightarrow$ Topsoil $\longrightarrow$ No Topsoil

Figure 34: $\mathrm{CH}-3$ second growing season average percent ground cover by soil (2016)

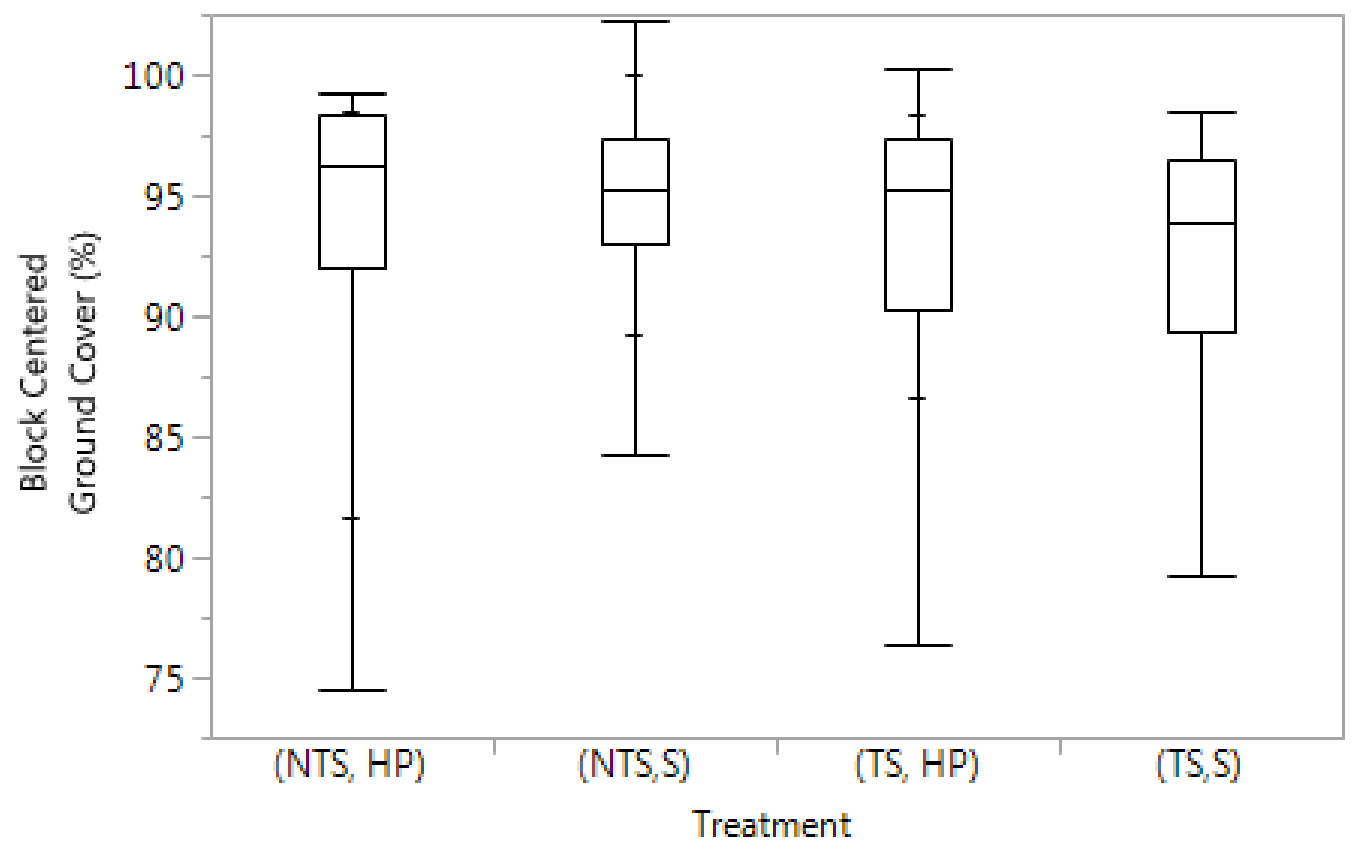

Figure 35: CH-3 distribution of ground cover for four seed bed treatments: no topsoil with HECP, no topsoil with straw mulch, topsoil with HECP, and topsoil with straw mulch; median (-); 25-75\% (box); $90 \%$ and $10 \%(-)$; min and max (whisker) (2016) 


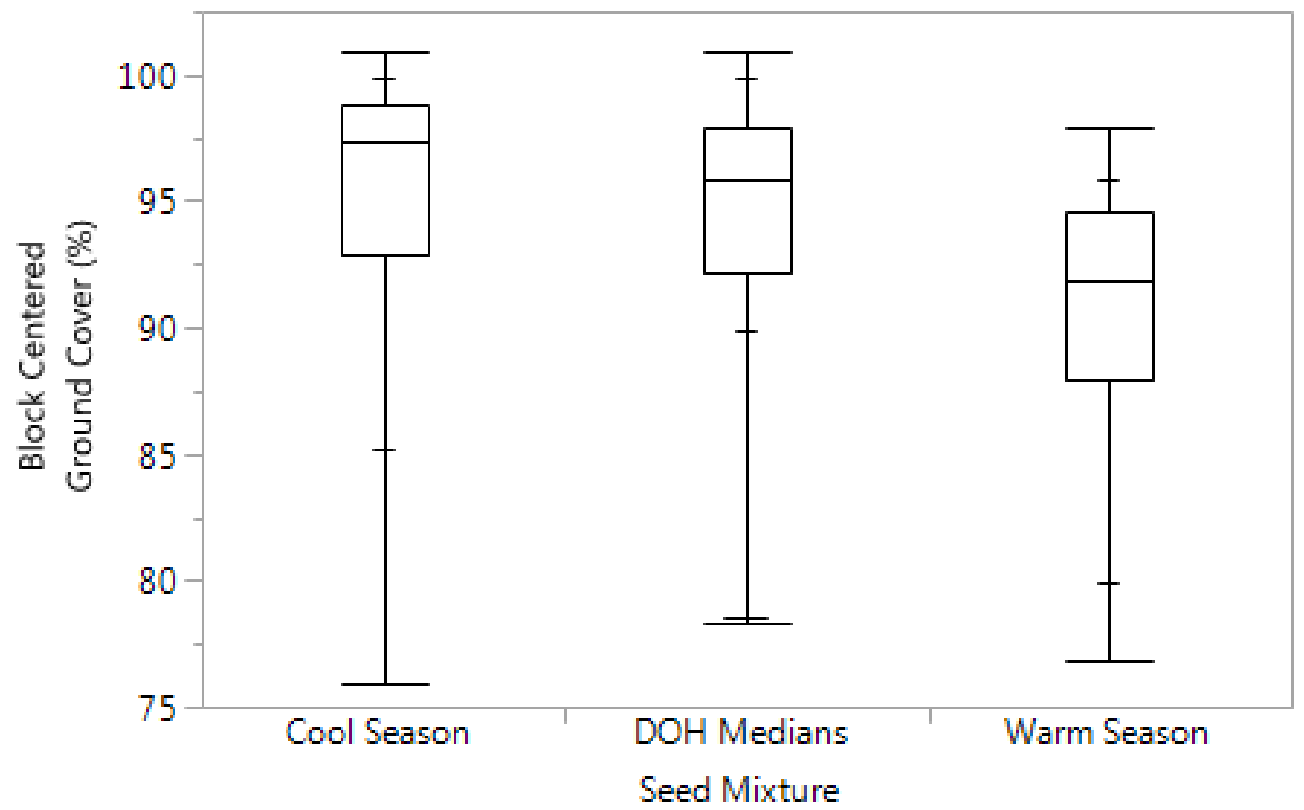

Figure 36: CH-3 distribution of ground cover for three seed mixtures: cool season, DOH Medians, and warm season; median (-); 25-75\% (box); $90 \%$ and $10 \%(-)$; min and max (whisker) (2016)

Subplots containing cool season mixtures resulted in the most ground cover of planted species on average than subplots containing any other seed mixture. Subplots with seed mixtures planted in topsoil contained higher ground cover of species that were not planted than subplots containing mixtures planted in the existing soil. Subplots containing DOH medians mixtures planted in topsoil resulted in the most ground cover of species that were not planted than any other seed mixture and mulch seed bed at the end of the season (Figure 37). 


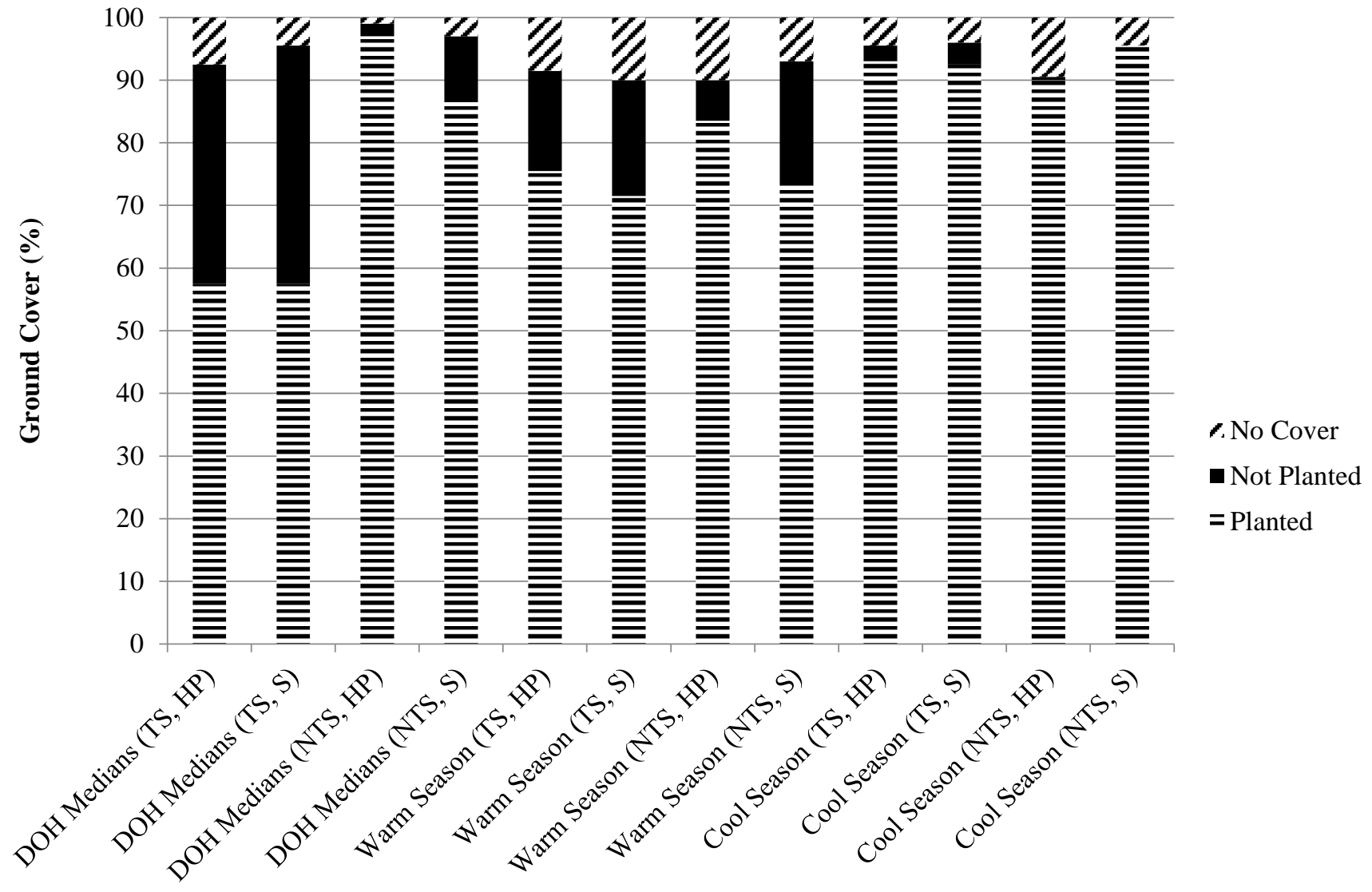

Figure 37: CH-3 average ground cover by species (October 2016)

Cool season mixture subplots resulted in the highest total biomass and lowest biomass from species that were not planted at the end of the season (Figure 38). Dunn method test of pairs of seed bed preparation treatments showed statistical similarity among all treatments (Figure 39). Similar results were indicated by Dunn's test with respect to total biomass of all pairs of seed mixtures (Figure 40). 


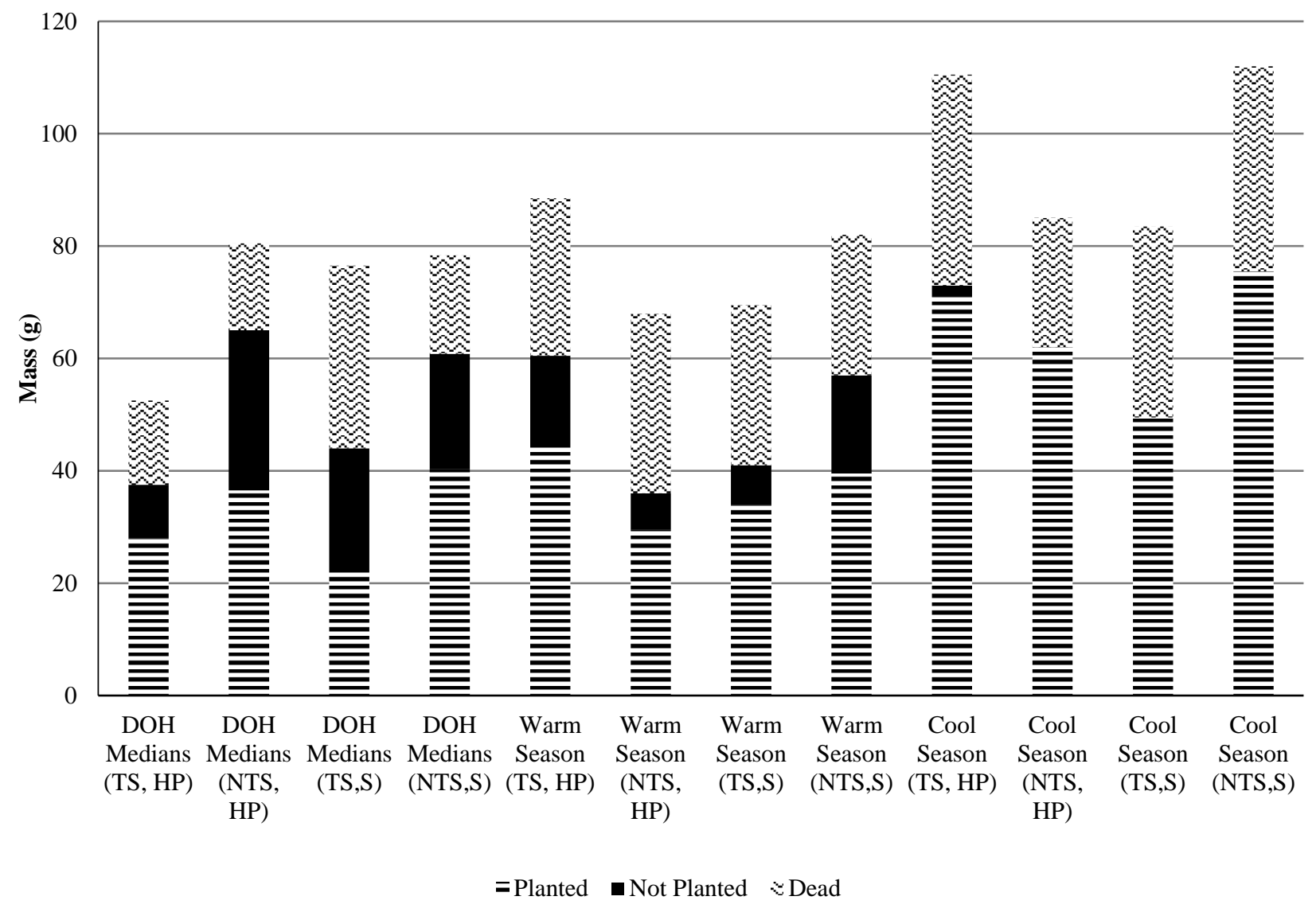

Figure 38: CH-3 total biomass weight (October 2016)

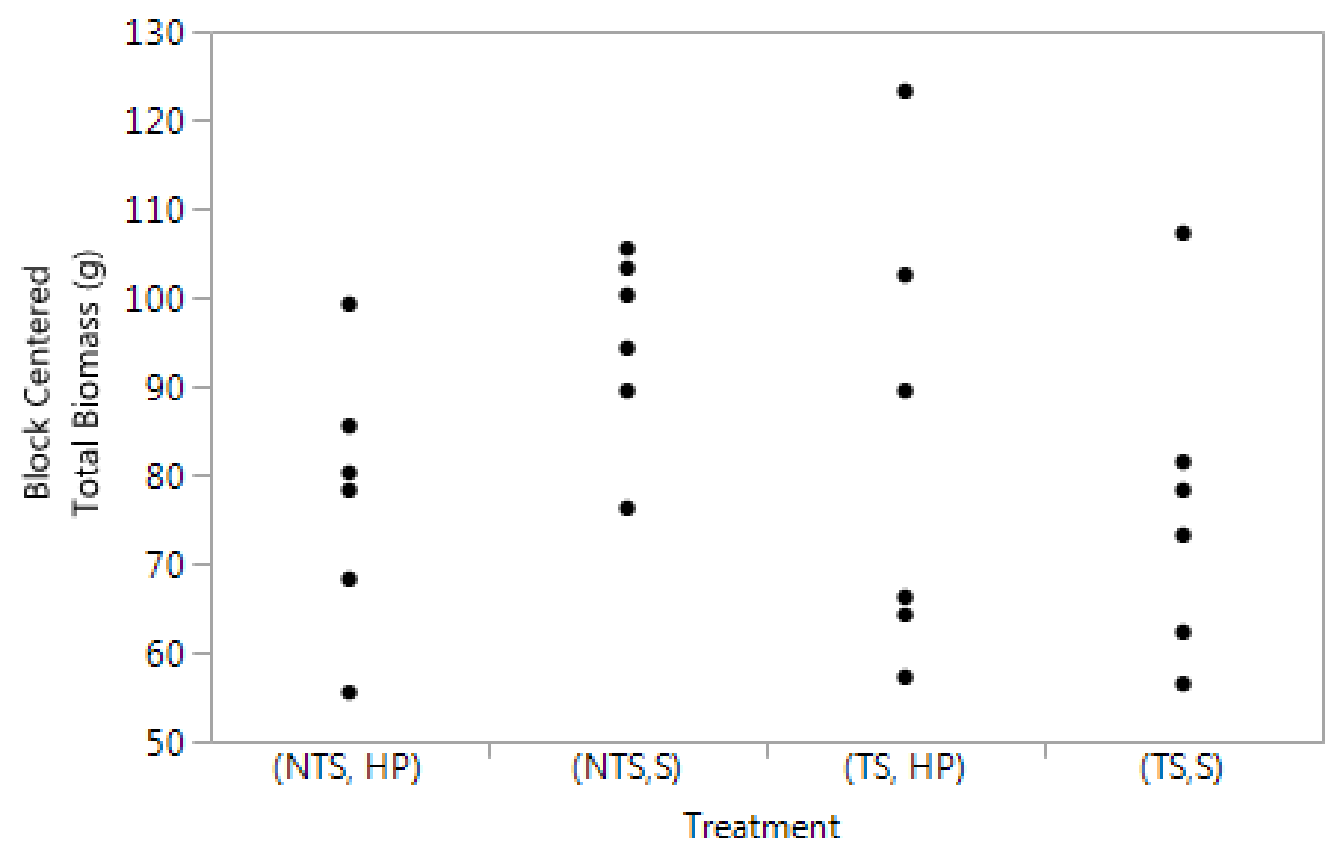

Figure 39: CH-3 distribution of biomass for four seed bed treatments: no topsoil with HECP, no topsoil with straw mulch, topsoil with HECP, and topsoil with straw mulch (2016) 


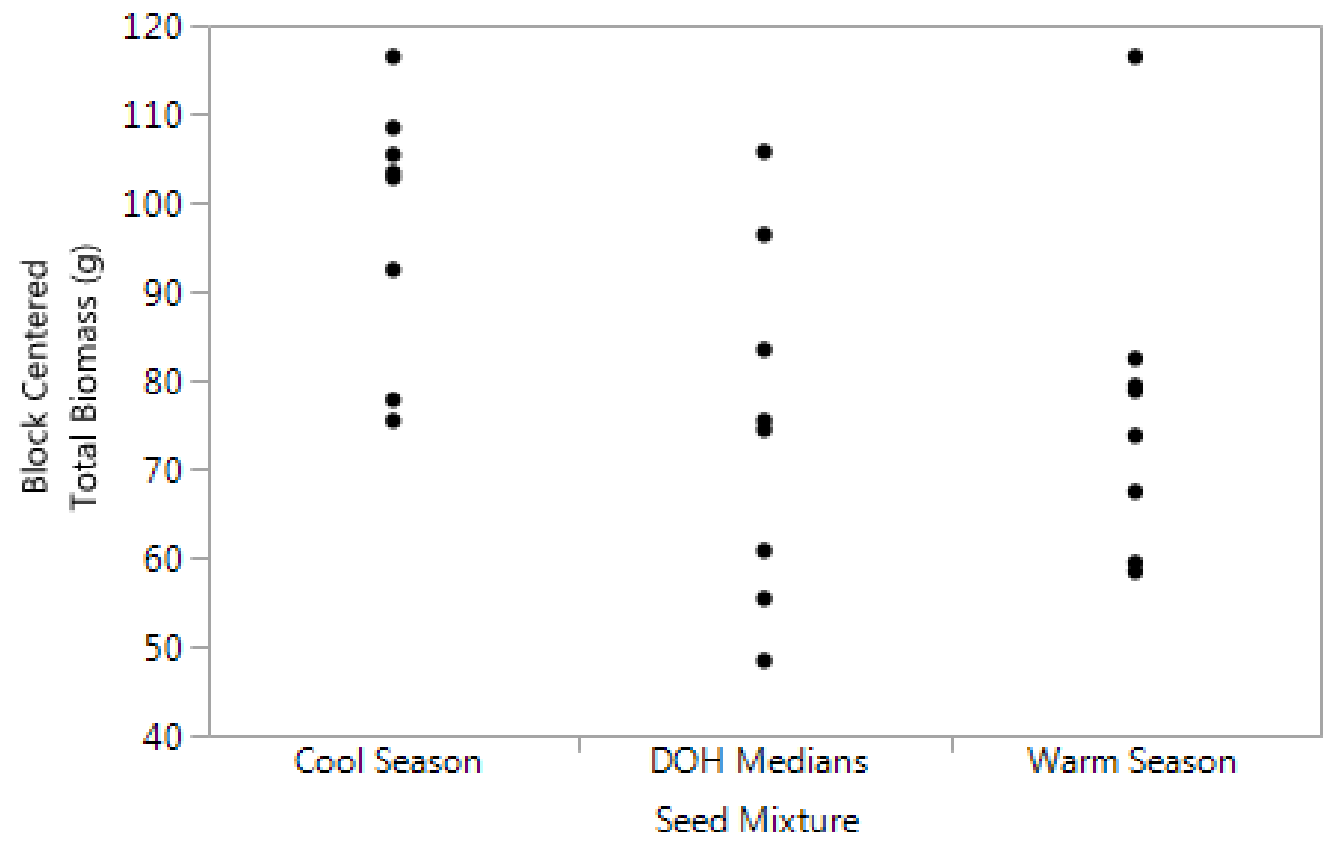

Figure 40: CH-3 distribution of biomass for three seed mixtures: cool season, DOH Medians, and warm season (2016)

\section{Third Growing Season (2017):}

Average ground cover remained above $75 \%$ at all subplots throughout the third growing season (Figure 41). Subplots planted with warm season seed mixtures resulted in the lowest average ground cover. One-way Kruskal-Wallis test indicated significant differences with respect to ground cover of different seed mixtures (p-value 0.0001). Dunn's test supported Kurskal-Wallis test by indicating differences in ground cover of warm season and DOH medians mixtures (pvalue 0.0011 ) and warm season and cool season mixtures (p-value $=0.0001)$ (Figure 46). There was not a substantial difference in percent ground cover in seed beds mulched using straw or HECP (Figure 43). Seed mixtures planted in the existing soil produced higher ground cover than seed beds that contained topsoil (Figure 44). One-way Kruskal-Wallis test of ground cover of different seed bed preparation treatments resulted in a p-value of 0.0703 (Figure 45). 


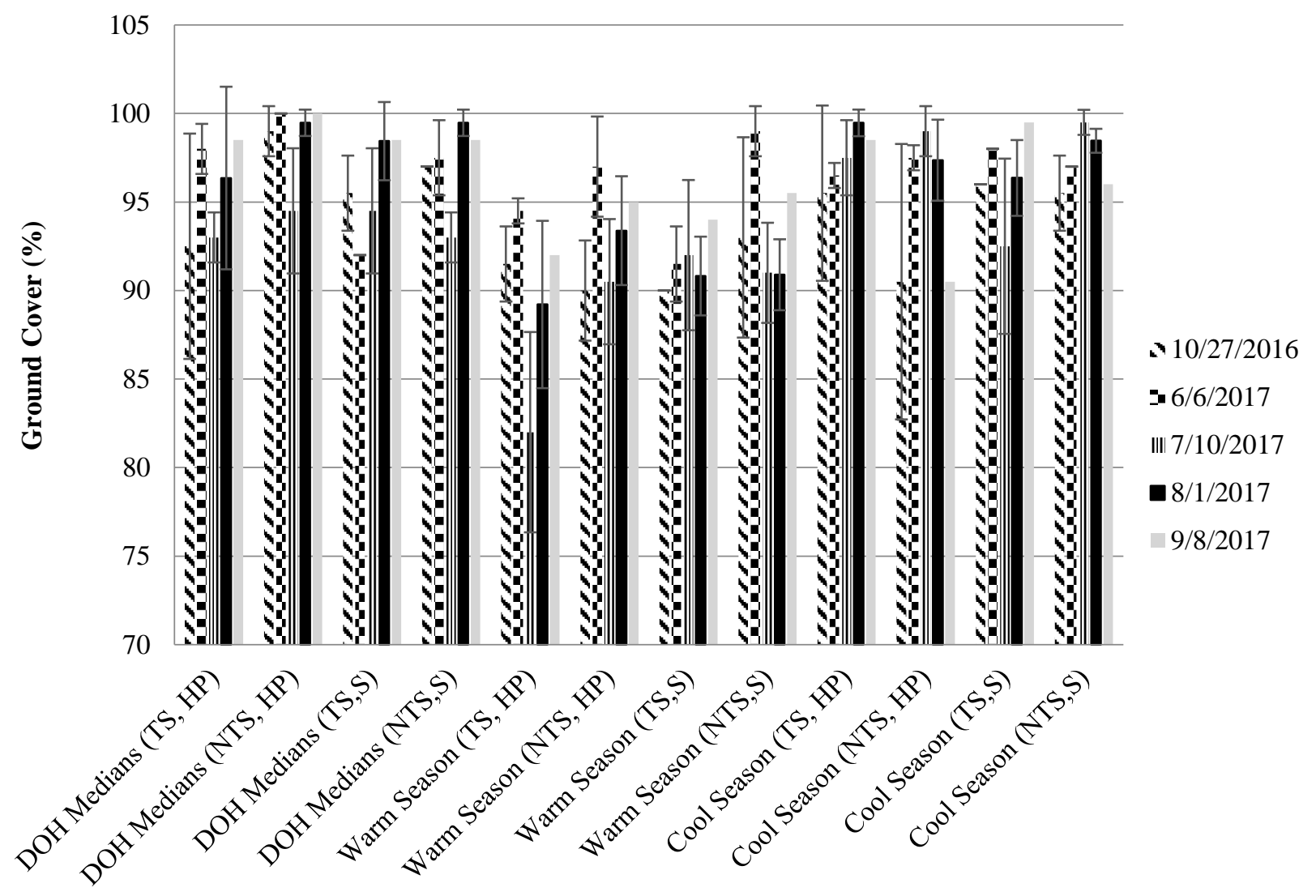

Figure 41: CH-3 third growing season average percent ground cover; error bars denote standard deviation (2017)

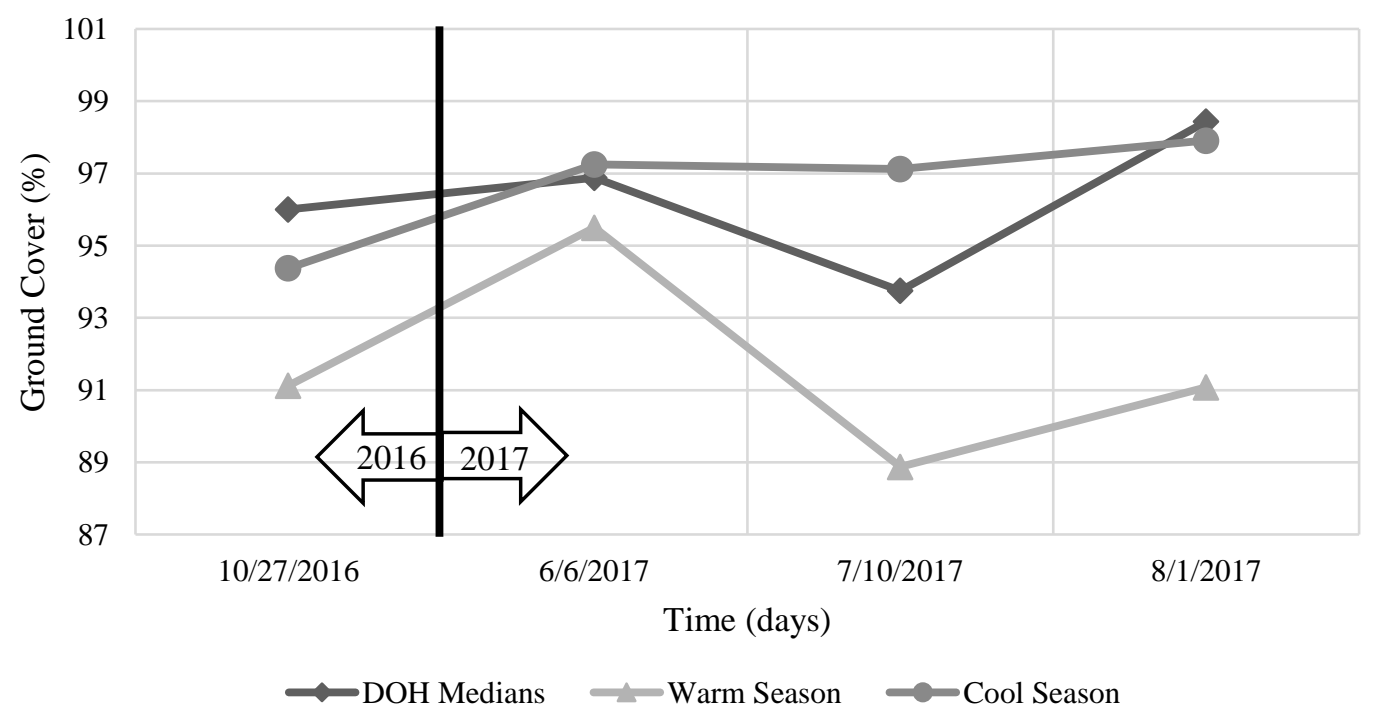

Figure 42: CH-3 third growing season average percent ground cover by seed mixture (2017) 


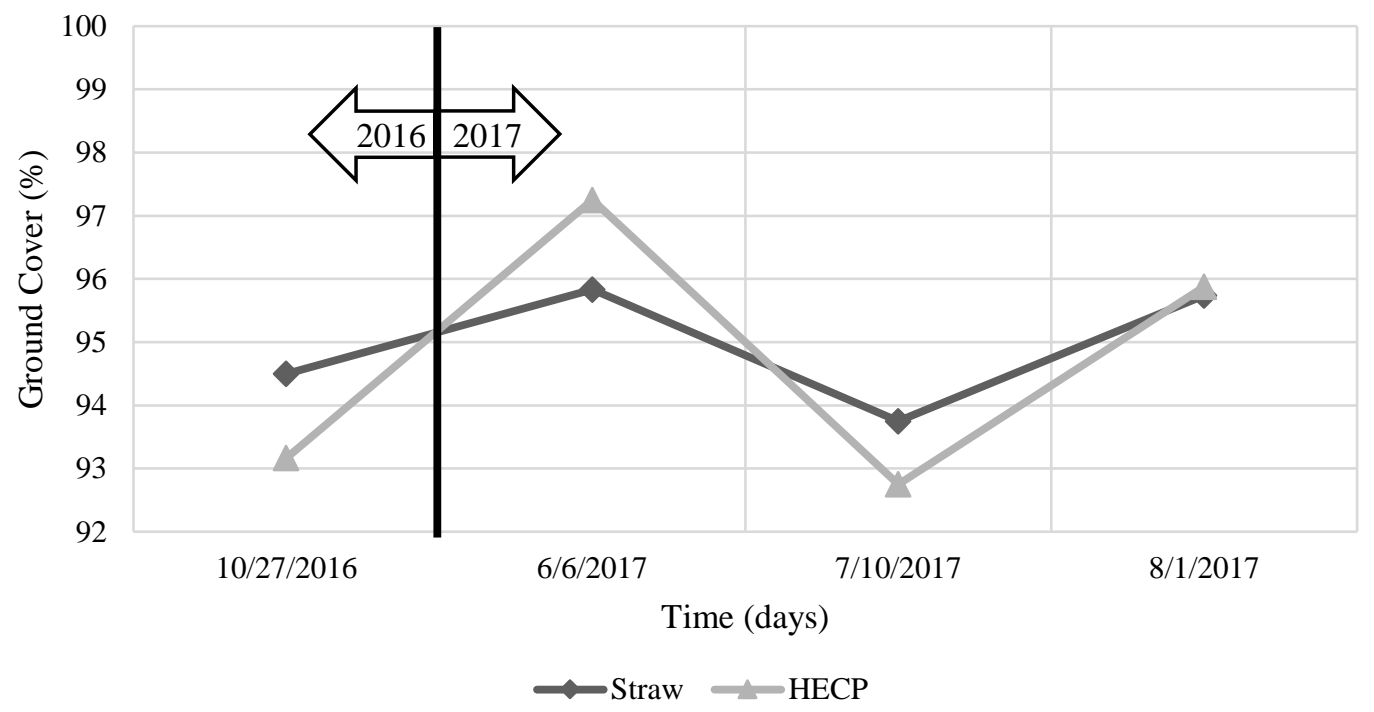

Figure 43: CH-3 third growing season average percent ground cover by mulch (2017)

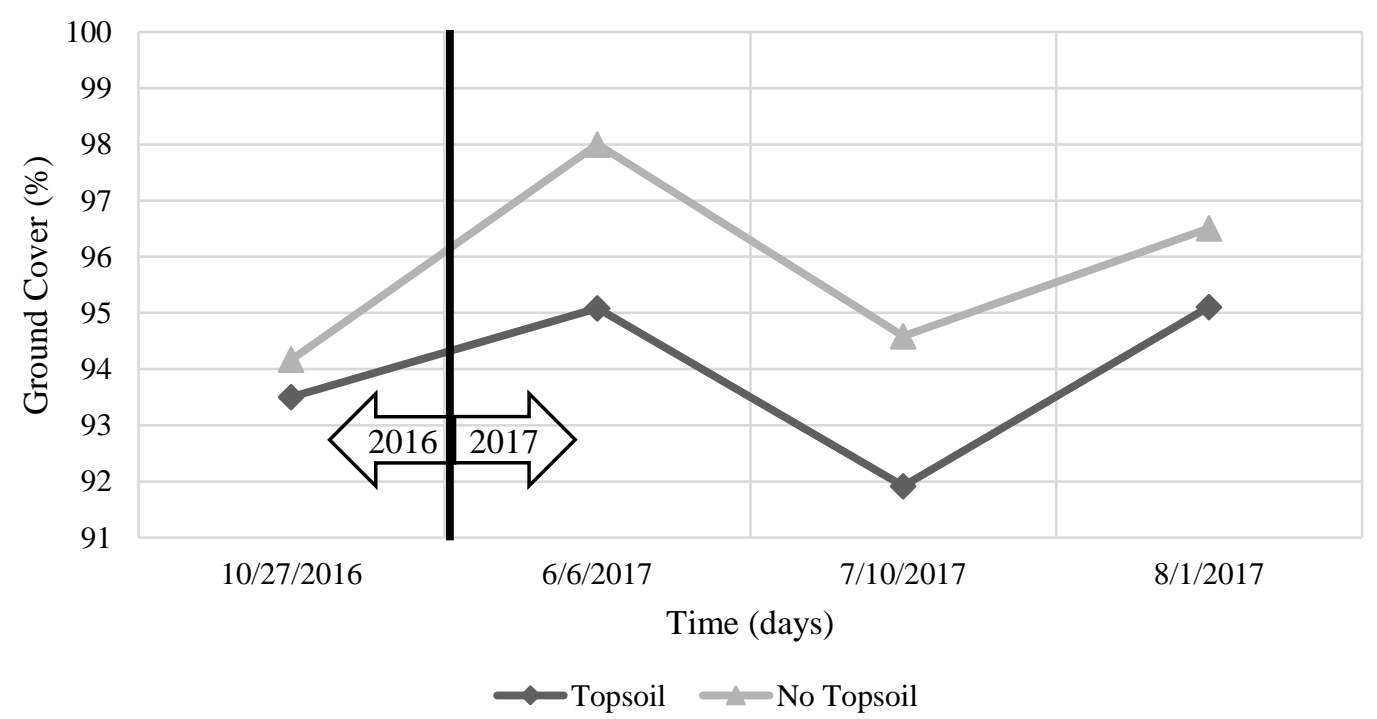

Figure 44: CH-3 third growing season average percent ground cover by soil (2017) 


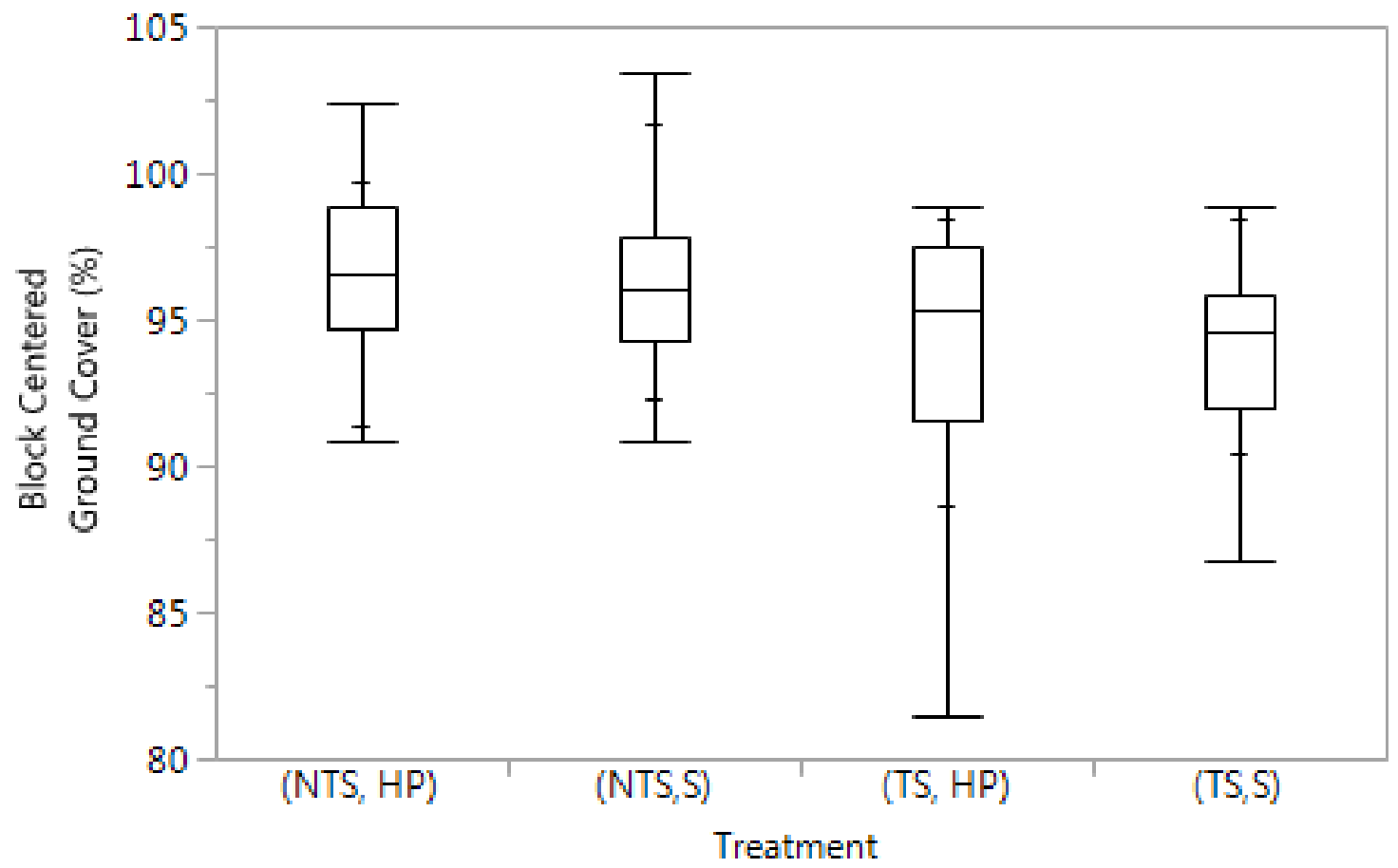

Figure 45: CH-3 distribution of ground cover for four seed bed treatments: no topsoil with HECP, no topsoil with straw mulch, topsoil with HECP, and topsoil with straw mulch; median (-); 25-75\% (box); 90\% and $10 \%(-)$; min and max (whisker) (2017)

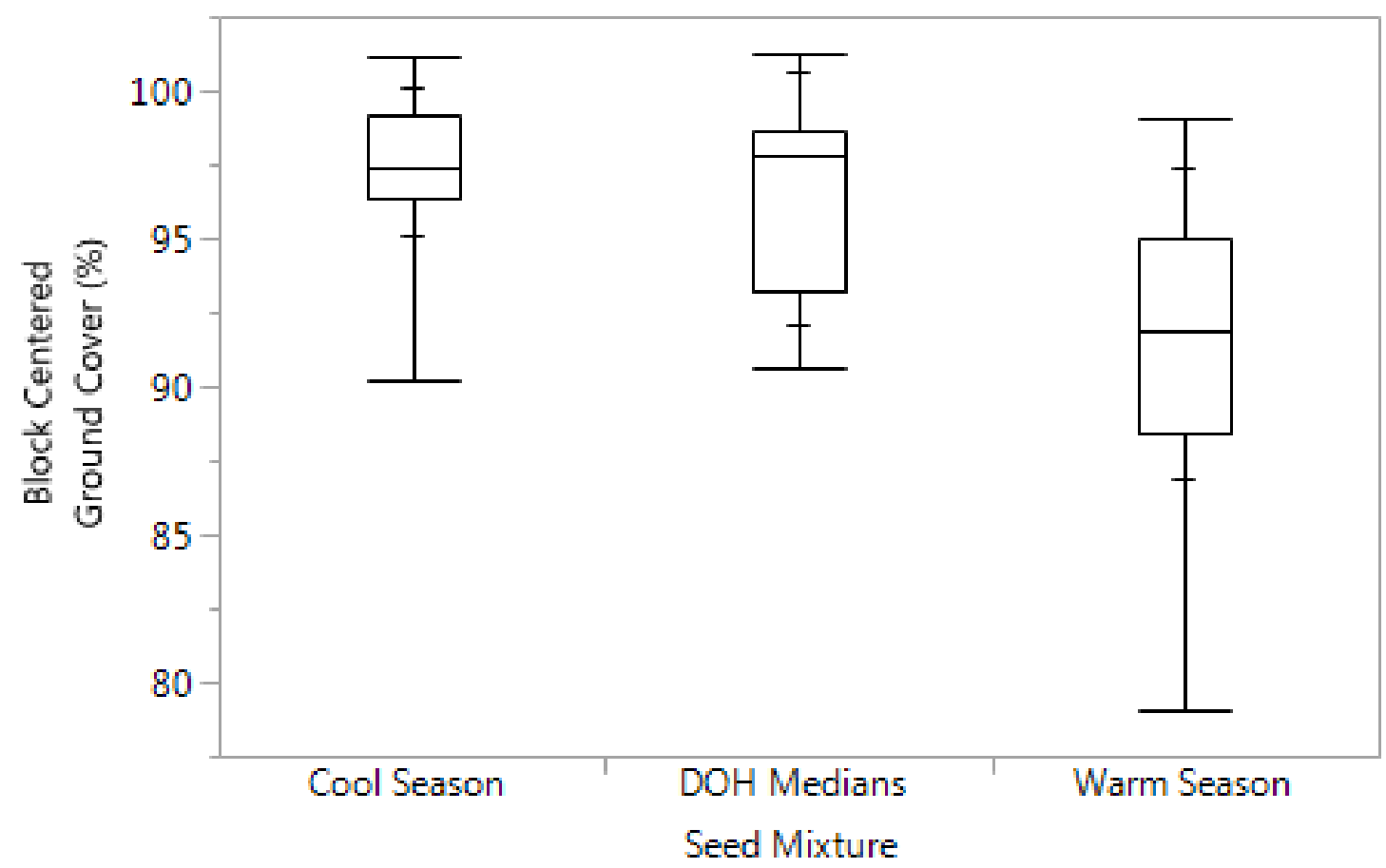

Figure 46: CH-3 distribution of ground cover for three seed mixtures: cool season, DOH Medians, and warm season; median (-); 25-75\% (box); $90 \%$ and $10 \%(-)$; min and max (whisker) (2017) 
Ground cover by species not contained in the seed mixtures was the least in subplots planted with experimental cool season mixtures and the most in subplots planted with WVDOH medians mixture. There was not a substantial difference in ground cover at subplots planted with or without topsoil or in subplots mulched with straw mulch or hydraulic erosion control product. Subplots containing experimental warm season mixtures resulted in the most area without ground cover during the third growing season (Figure 47).

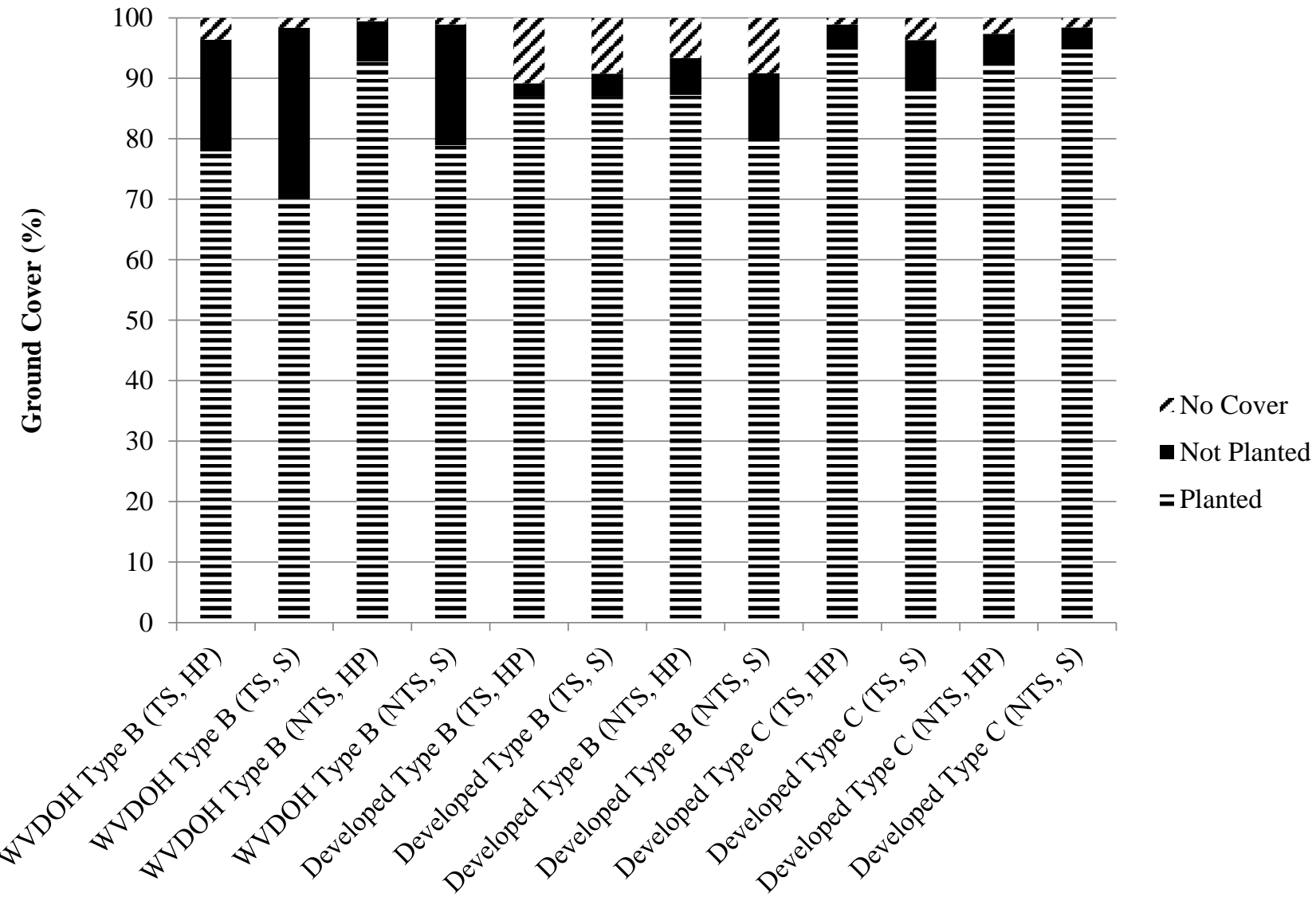

Figure 47: CH-3 average ground cover by species (August 2017)

Subplots planted with experimental cool season mixtures contained the most total biomass during the third growing season. DOH medians mixture subplots contained the most biomass from species that were not planted (Figure 48). Dunn's test indicated no significant statistical differences in total biomass between difference seed bed preparation treatments (Figure 49). However, Dunn method test resulted in differences in total biomass between DOH medians and cool season mixtures $(p-v a l u e=0.0001)($ Figure 50) 


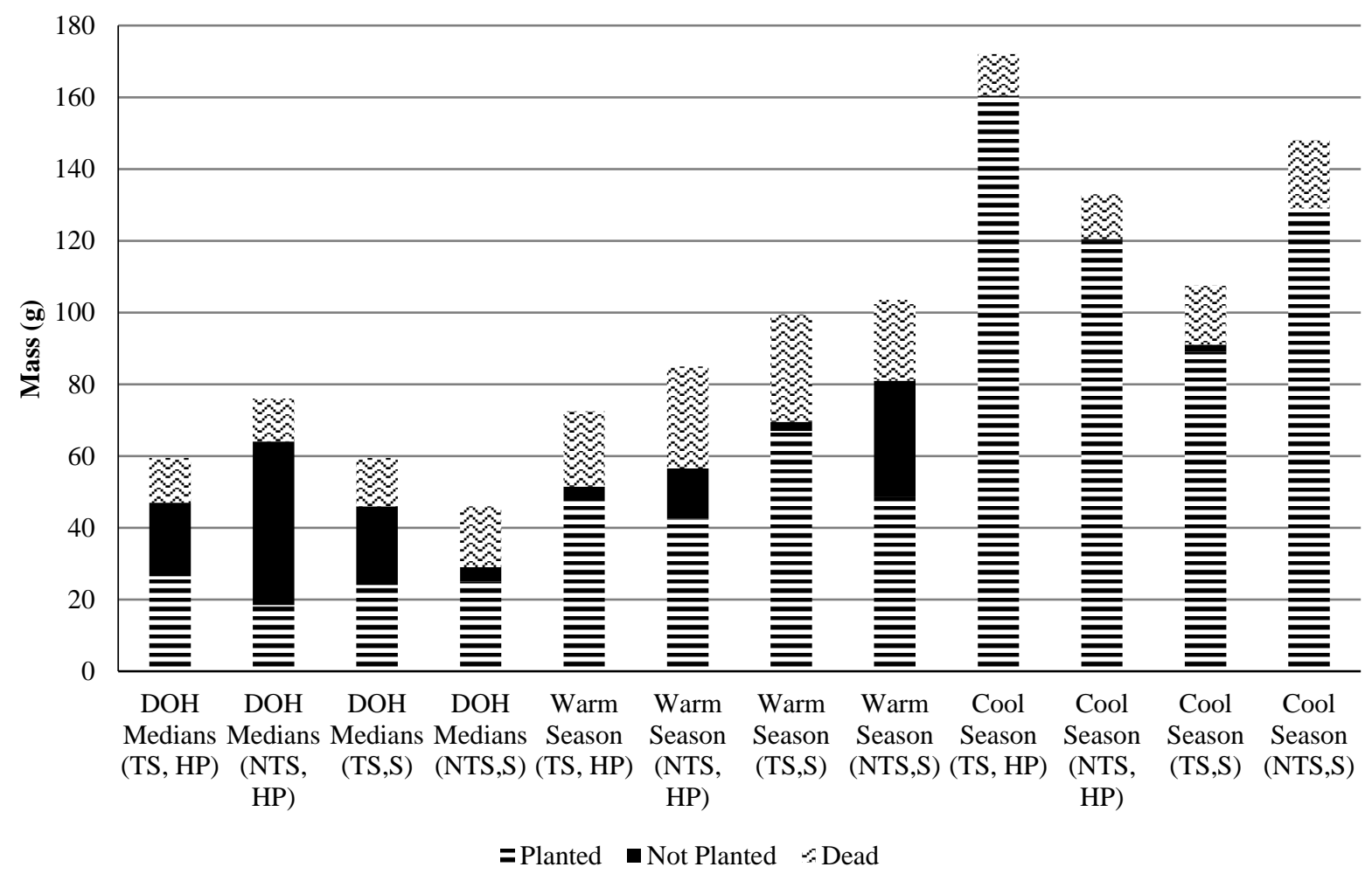

Figure 48: CH-3 total biomass weight (July 2017)

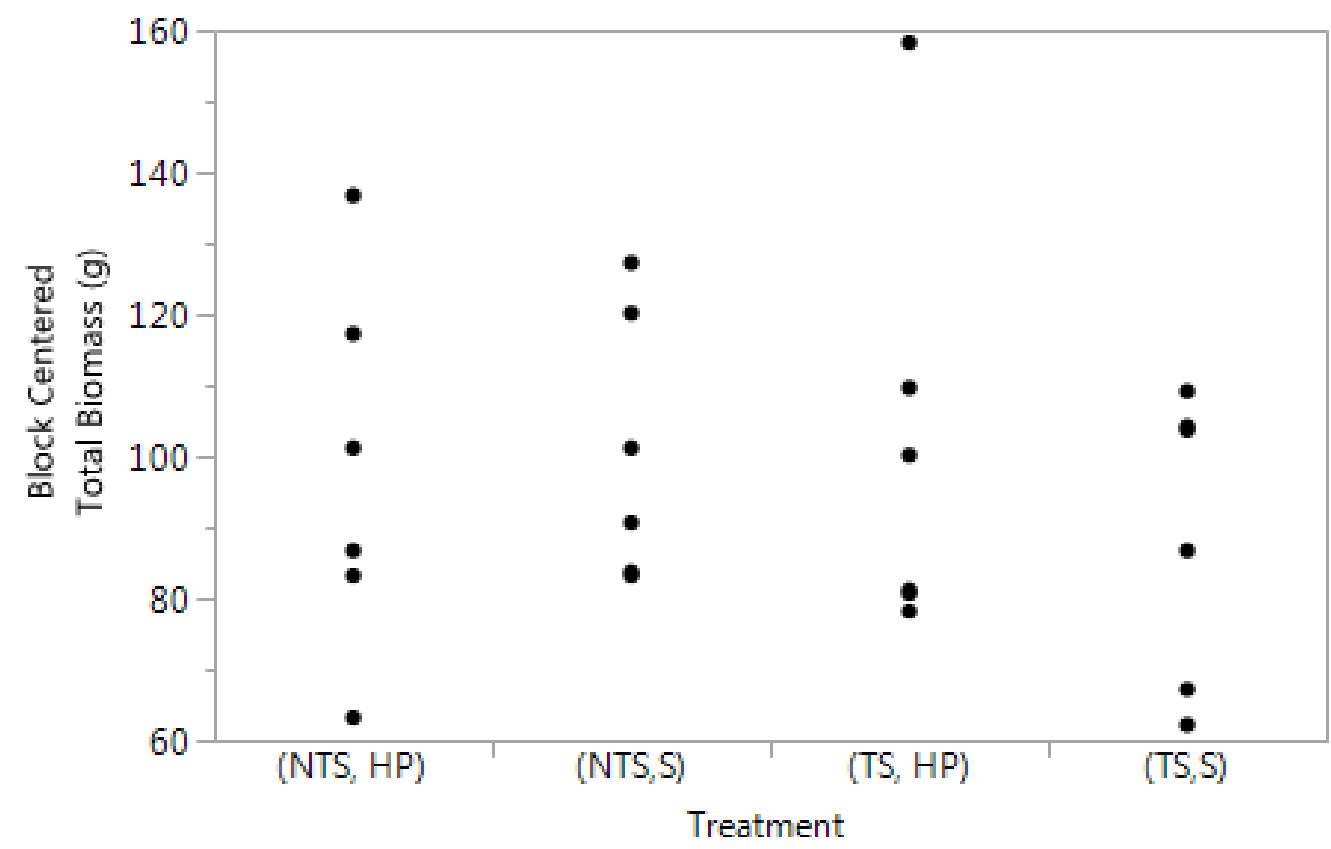

Figure 49: CH-3 distribution of biomass for four seed bed treatments: no topsoil with HECP, no topsoil with straw mulch, topsoil with HECP, and topsoil with straw mulch (2017) 


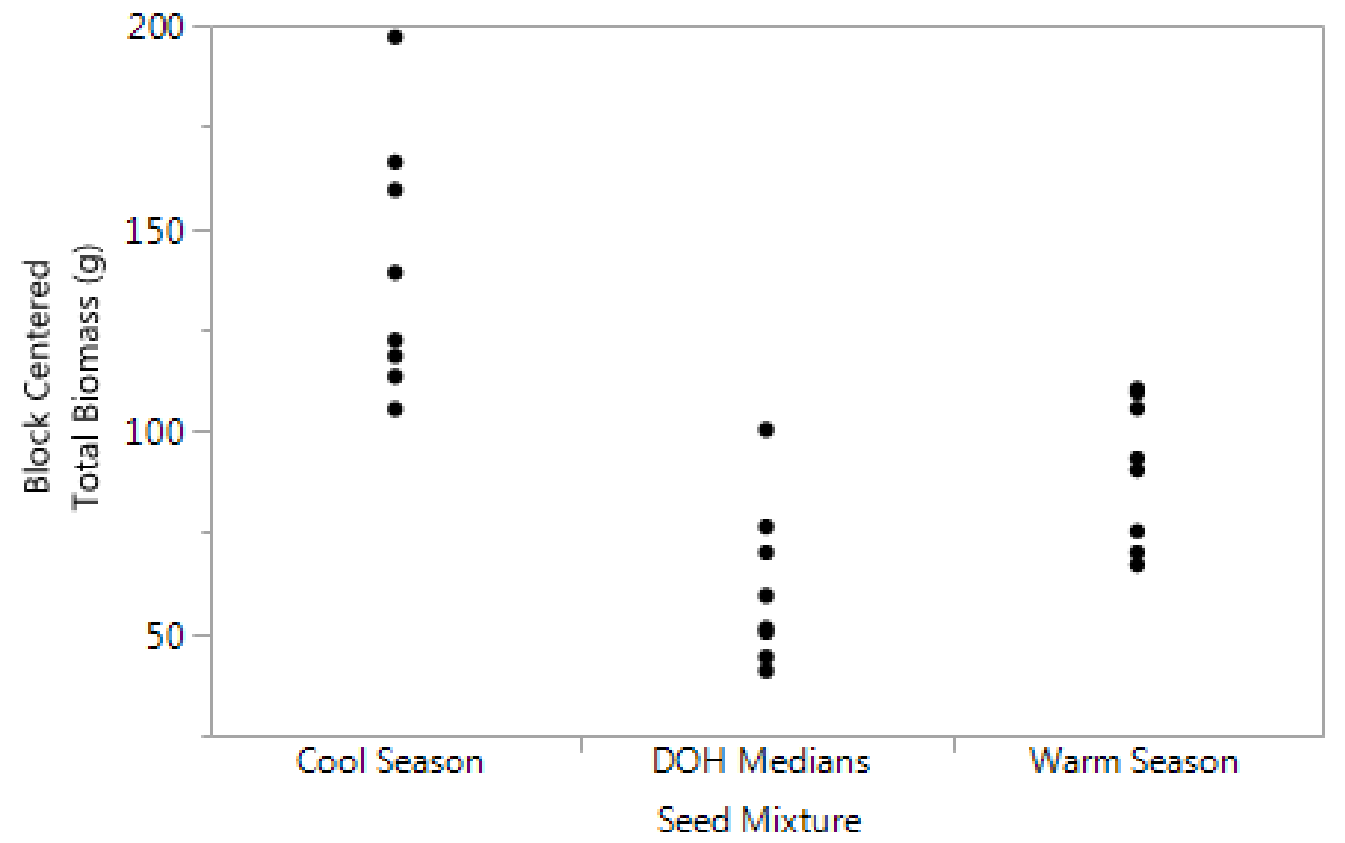

Figure 50: CH-3 distribution of biomass for three seed mixtures: cool season, DOH Medians, and warm season (2016)

\subsubsection{Soil}

Organic matter increased in all four treatments from soil conditions before disturbance until the end of the second growing season, except in treatments containing topsoil. Soil $\mathrm{pH}$ decreased in all four seed bed treatments. Soil nutrient fluctuation varied among different treatments from prior to disturbance until the end of the second growing season (Table 9).

Table 9: $\mathrm{CH}-3$ end of season soil analysis results

\begin{tabular}{lllllll}
\hline Date & Treatment & OM $(\%)$ & $\mathbf{N}(\mathbf{p p m})$ & $\mathbf{K}(\mathbf{p p m})$ & $\mathbf{P}(\mathbf{p p m})$ & $\mathbf{p H}$ \\
\hline Before Disturbance & $*$ & 1 & 3 & 79 & 12 & 8.1 \\
$10 / 27 / 2016$ & Topsoil w/ Straw & 2.4 & 3 & 93 & 12 & 7.6 \\
& Topsoil w/ HECP & 2.2 & 1 & 81 & 10 & 7.5 \\
& Existing Soil w/ Straw & 2 & 2 & 100 & 19 & 7.6 \\
& Existing Soil w/ HECP & 1.8 & 1 & 111 & 28 & 7.9 \\
\hline
\end{tabular}

*Soil sample of parent material before construction of plots with treatments

\subsubsection{CH-1B: Testing Soil Amendments}

\subsubsection{Temperature and Precipitation}

Temperature and precipitation data for $\mathrm{CH}-1 \mathrm{~B}$ were the same as section 2.4.1.1 because the same equipment was used due to the close proximity of the sites. 


\subsubsection{Vegetation}

\section{Second Growing Season (2016):}

All treatments resulted in average ground cover greater than $85 \%$ by the end of the season. There was a considerable decrease in ground cover from August to September, but vegetation was restored from September to October (Figure 51). One-way Kruskal-Wallis test indicated that there was no significant difference between ground cover of different treatments throughout the growing season $(\mathrm{p}$-value $=0.5626)($ Figure 52$)$.

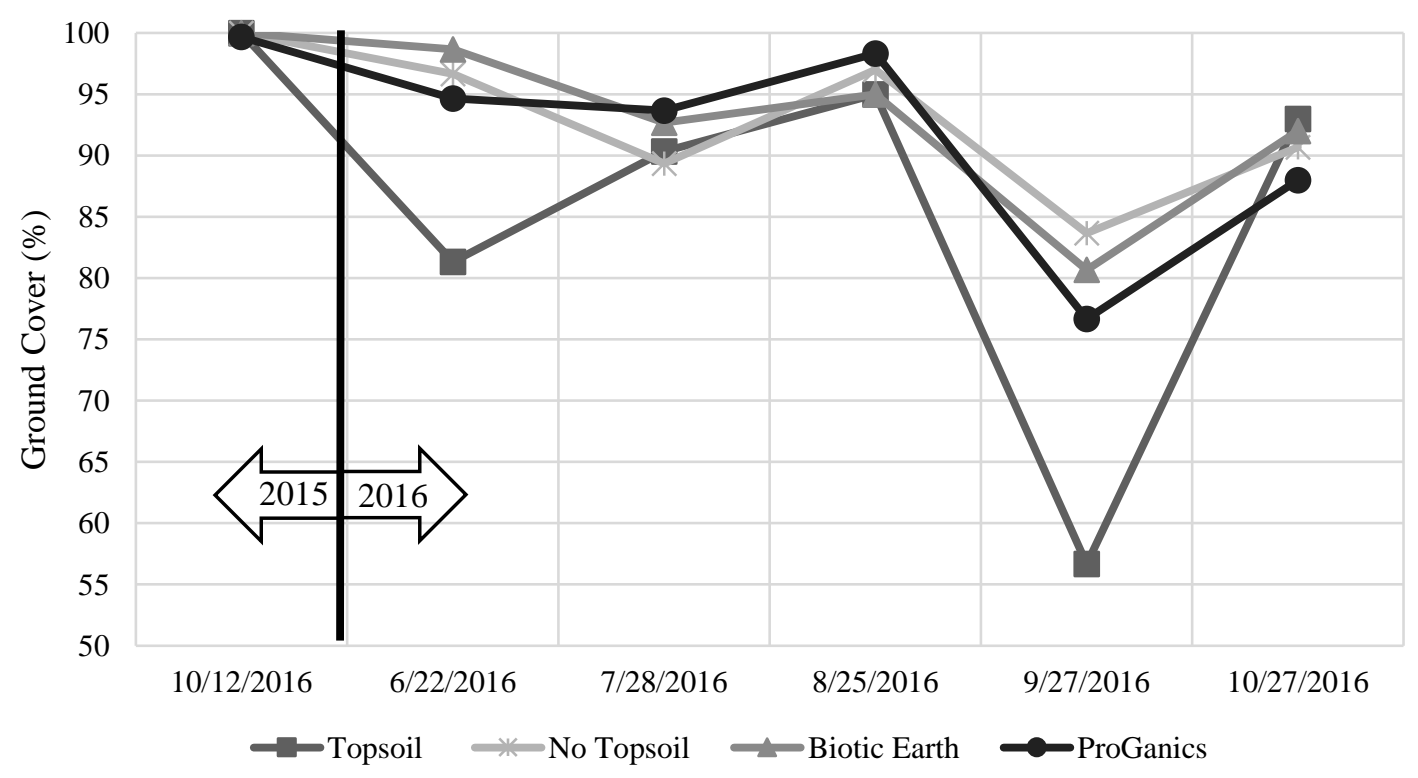

Figure 51: CH-1B second growing season average percent ground cover (2016) 


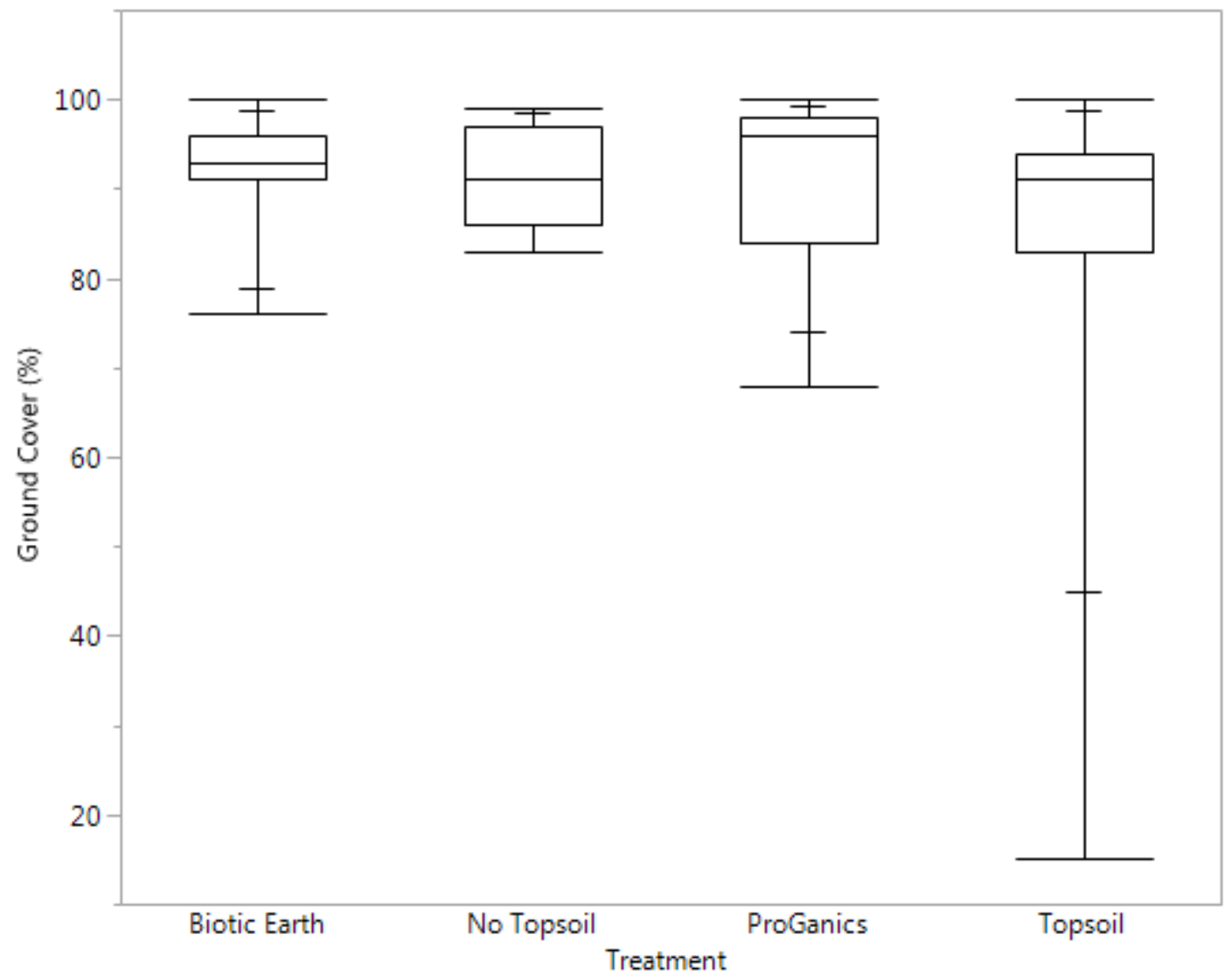

Figure 52: CH-1B distribution of ground cover for four treatments: Biotic Earth, no topsoil, ProGanics, and topsoil; median (-); 25-75\% (box); $90 \%$ and $10 \%(-)$; min and max (whisker) (2016)

All subplots resulted in $80 \%$ or greater ground cover by species that were planted. Biotic Earth subplots resulted in the highest percentage of species that were not planted at the end of the growing season. Subplots planted in existing soil and ProGanics both contained only 3\% species that were not planted (Figure 53). 


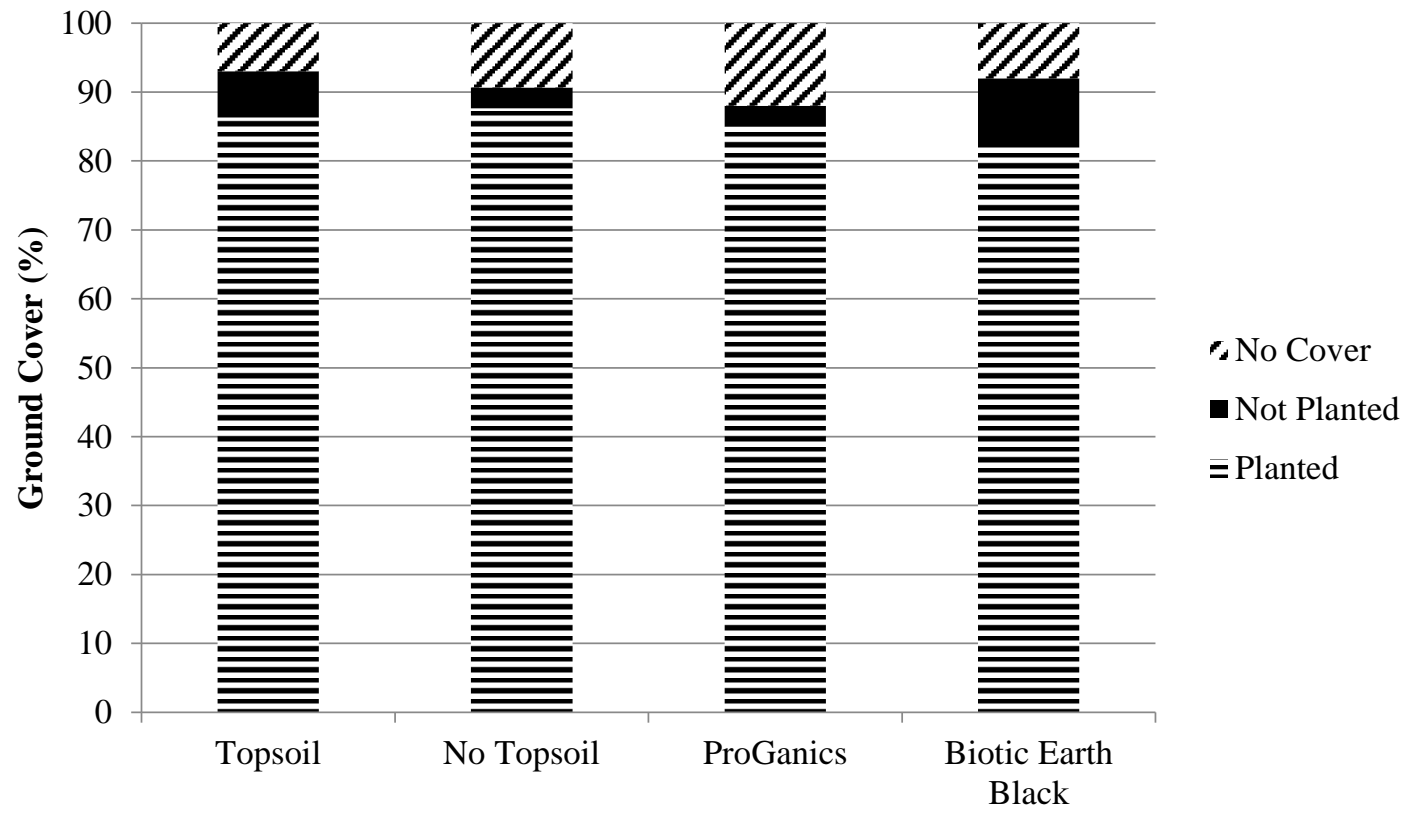

Figure 53: CH-1B average ground cover by species (October 2016)

Biomass of species that were not planted was considerably low in the entire plot. ProGanics subplots resulted in the highest total biomass. Subplots prepared in the existing soil produced the highest mass of planted species (Figure 54). Dunn's test indicated no significant differences in total biomass between any treatments (Figure 55).

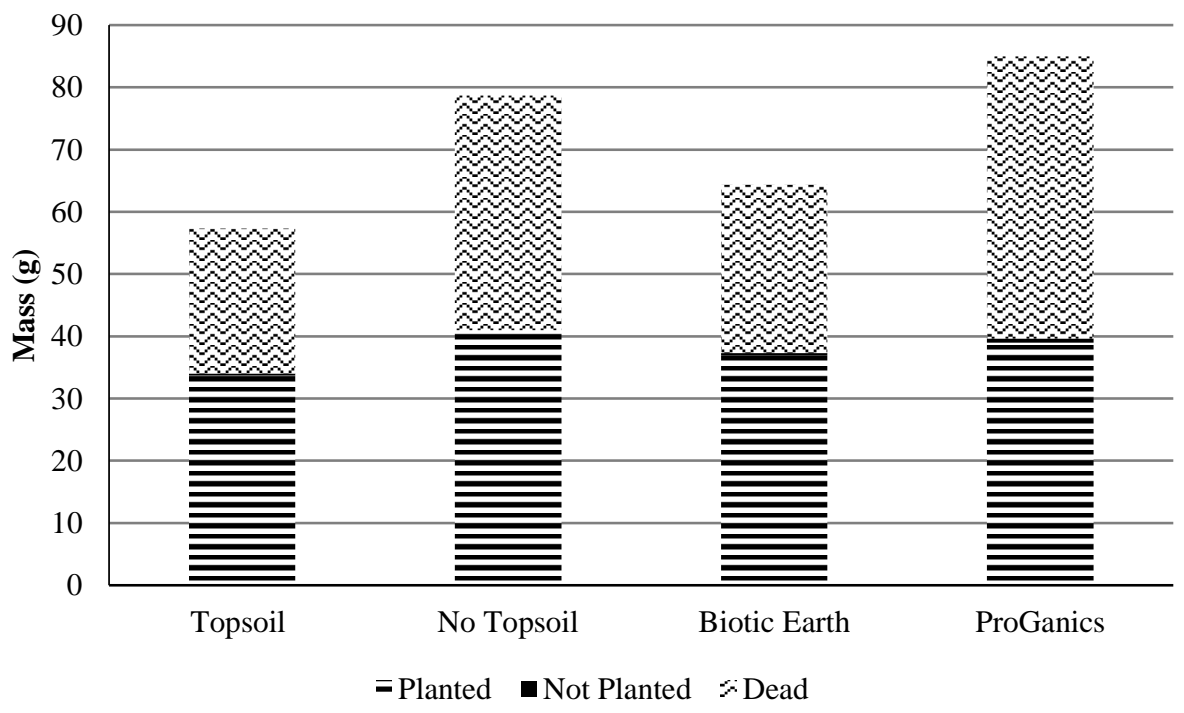

Figure 54: CH-1B total biomass weight (October 2016) 


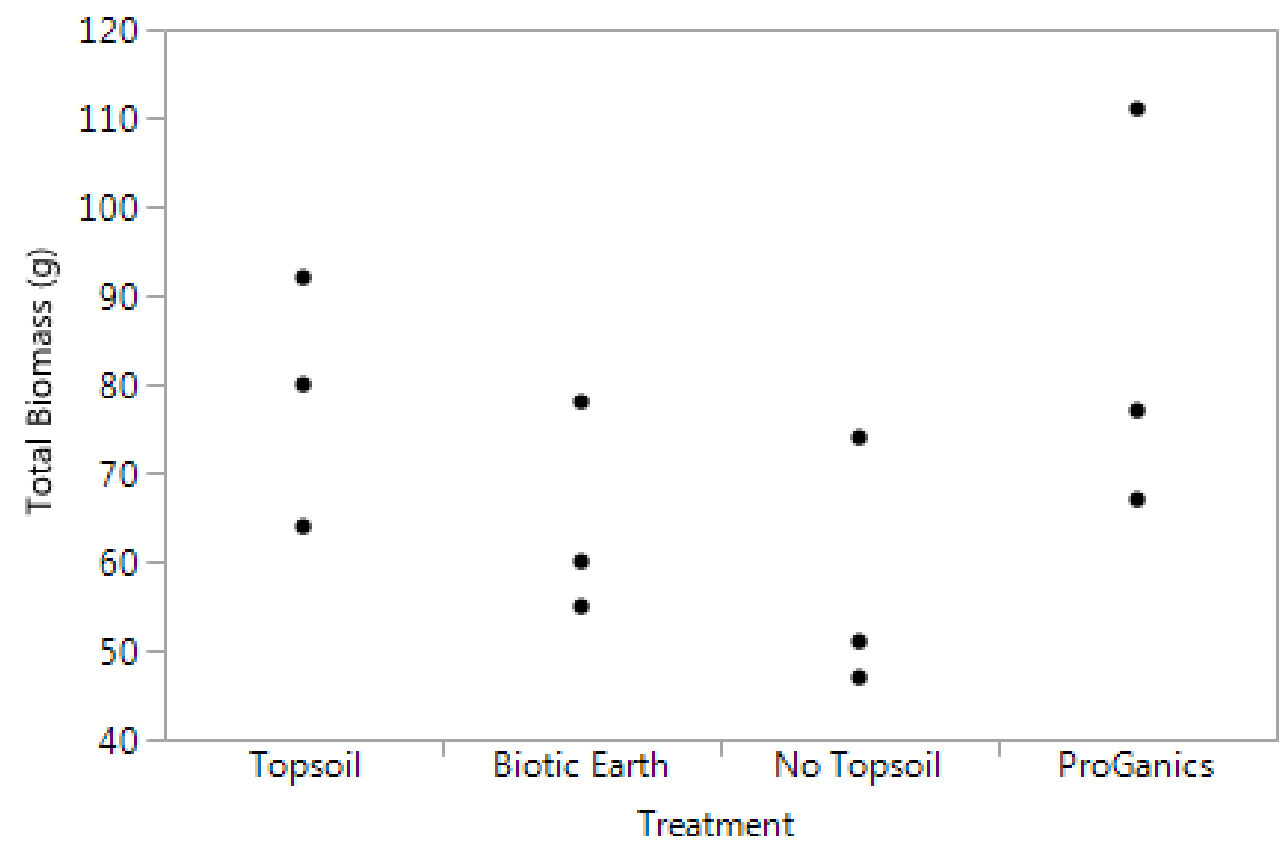

Figure 55: CH-1B distribution of biomass for four treatments: Biotic Earth, no topsoil, ProGanics, and topsoil; median (-); 25-75\% (box) (2016)

\section{Third Growing Season (2017):}

Ground cover throughout the entire plot remained $70 \%$ or greater during the entire third growing season (Figure 56). Although subplots planted in Biotic Earth had the highest average ground cover throughout the third growing season, there was no significant difference between ground cover in subplots planted in different soil amendments (p-value $=0.7819)$ (Figure 57).

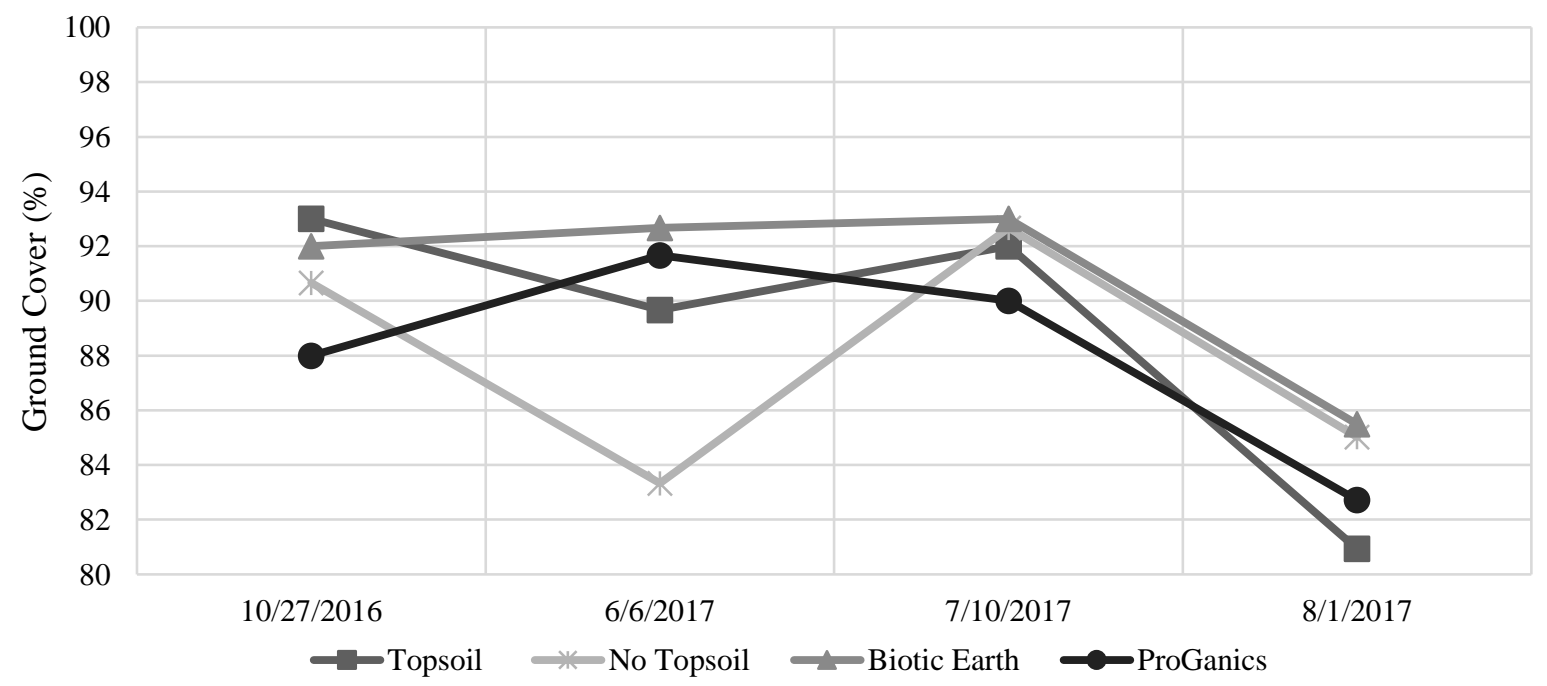

Figure 56: CH-1B third growing season average percent ground cover (2017) 


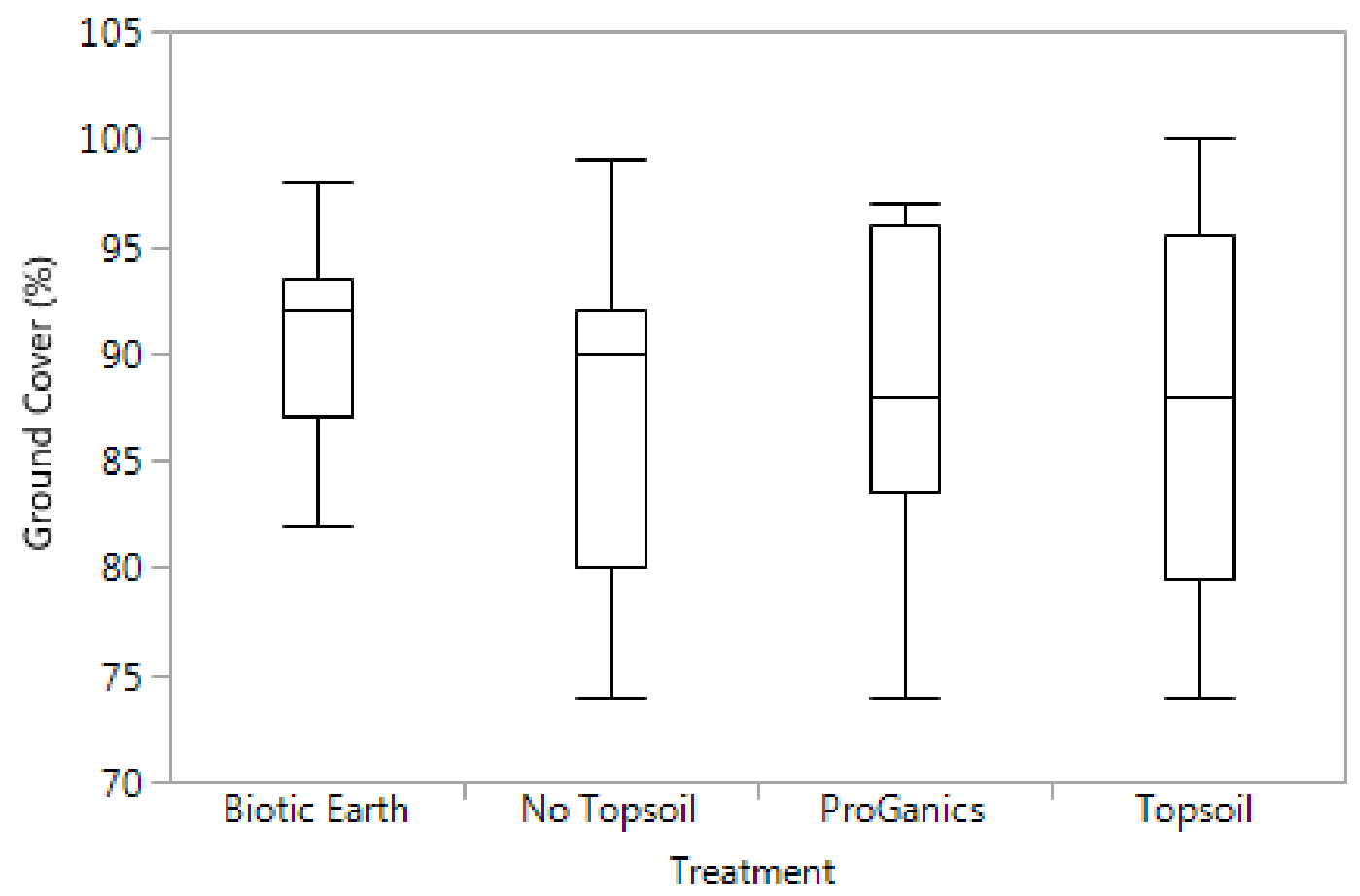

Figure 57: CH-1B distribution of ground cover for four treatments: Biotic Earth, no topsoil, ProGanics, and topsoil; median (—); 25-75\% (box); min and max (whisker) (2017)

Seed beds prepared using topsoil resulted in the most ground cover by the third growing season by species that were not contained in the seed mixture at planting. Topsoil subplots also contained the most area without ground cover. Subplots prepared in the existing soil resulted in the most ground cover by species that were planted over all other soil amendments (Figure 58).

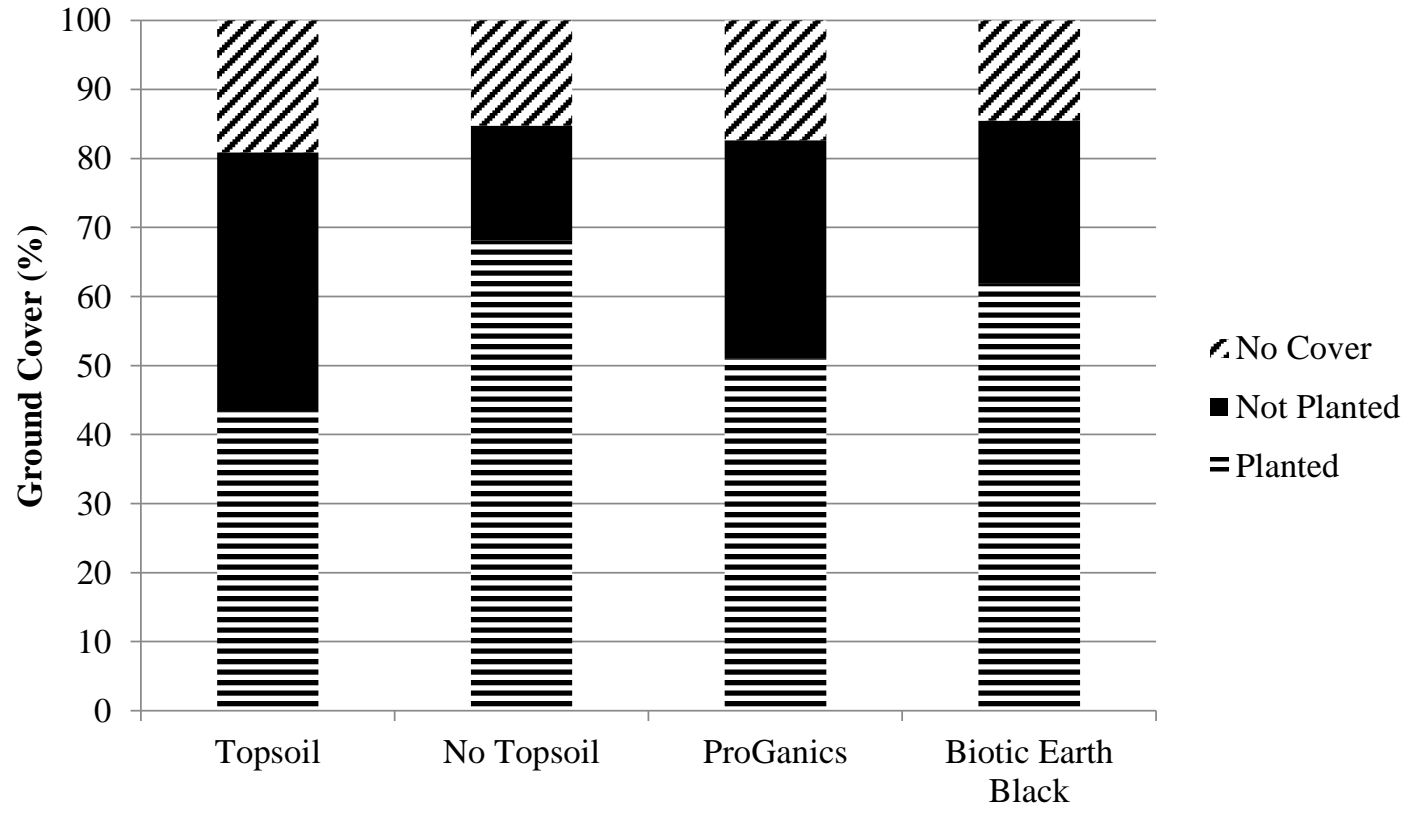

Figure 58: CH-1B average ground cover by species (August 2017) 
Subplots prepared with ProGanics produced the most total biomass, but also contained the most biomass from species that were not planted. Subplots prepared in existing soil produced the most biomass from planted species. Dunn's test indicated that there was no significant difference in total biomass across the entire plot (Figure 59, Figure 60).

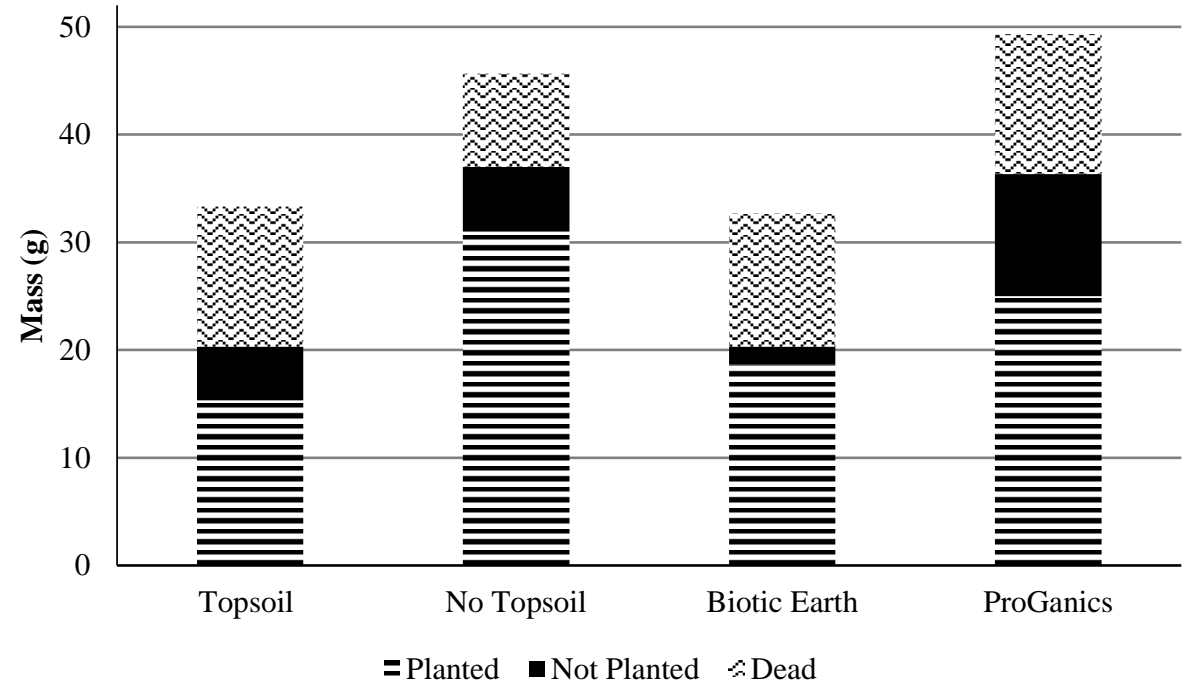

Figure 59: CH-1B total biomass weight (July 2017)

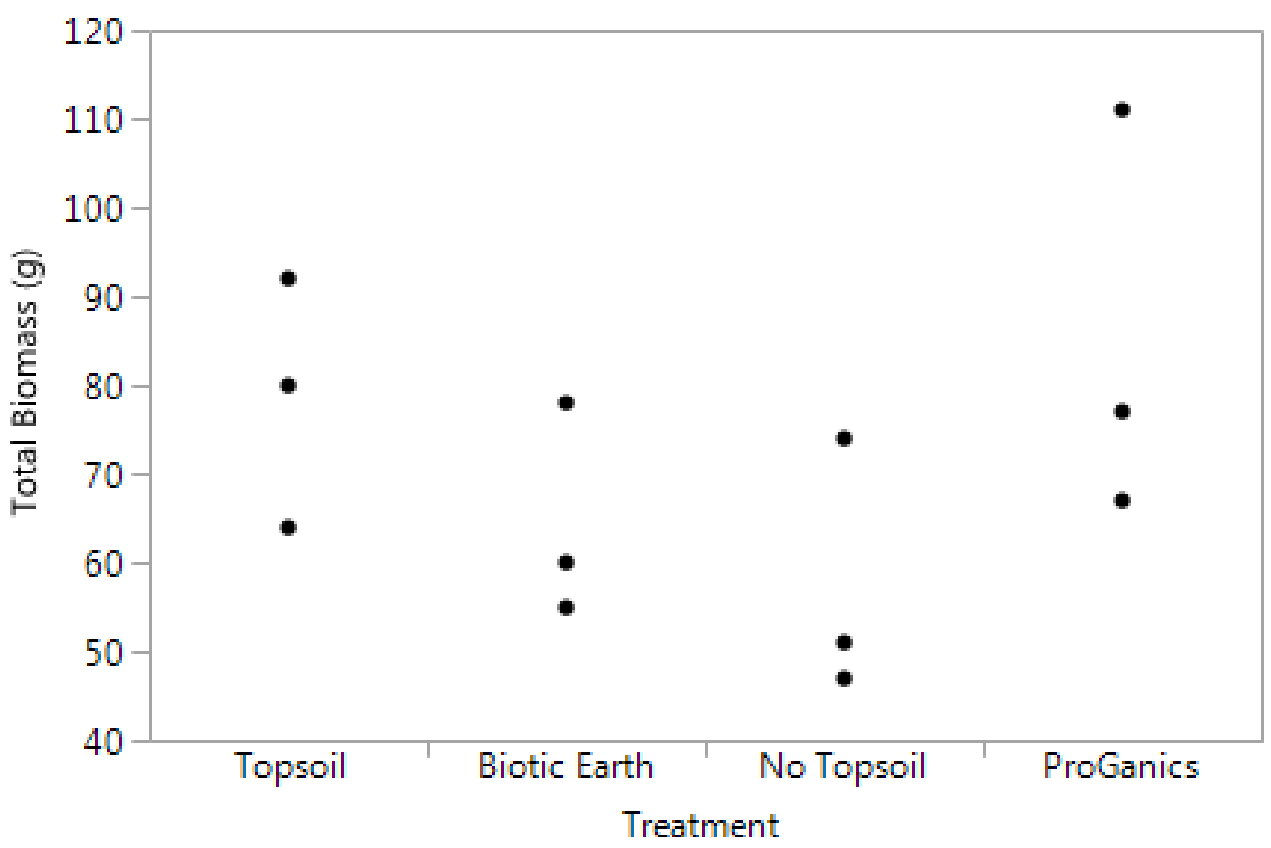

Figure 60: CH-1B distribution of biomass for four treatments: Biotic Earth, no topsoil, ProGanics, and topsoil; median (一); 25-75\% (box); letters denote statistical similarity (2017) 


\subsubsection{Soil}

Organic matter increased considerably ( $0.9 \%$ or greater) across the entire plot from before disturbance until the end of the second growing season. Soil $\mathrm{pH}$ also increased in all treatments (Table 10).

Table 10: CH-1B end of season soil analysis results

\begin{tabular}{lllllll}
\hline Date & Treatment & $\mathbf{O M}(\boldsymbol{\%})$ & $\mathbf{N}(\mathbf{p p m})$ & $\mathbf{K}(\mathbf{p p m})$ & $\mathbf{P}(\mathbf{p p m})$ & $\mathbf{p H}$ \\
\hline Before Disturbance & $*$ & 1.3 & 3 & 101 & 6 & 5.9 \\
$10 / 27 / 2016$ & Existing Soil & 2.8 & 8 & 136 & 39 & 7.7 \\
& Biotic Earth & 3.2 & 11 & 213 & 44 & 7.7 \\
& ProGanics & 3.3 & 6 & 148 & 30 & 7.7 \\
& Topsoil & 2.1 & 2 & 90 & 11 & 7.2 \\
\hline
\end{tabular}

*Soil sample of parent material before construction of plots with treatments

\subsection{Discussion}

\subsubsection{CH-1A}

Ground cover in the second growing season decreased, likely a result of low precipitation depths from the end of June until the end of July $(1.66 \mathrm{in}(4.22 \mathrm{~cm})$ total precipitation from June 28-July 28). Ground cover was restored above $98 \%$ cover for all mixtures following the drought period that occurred in July 2016. A drought period is also potentially the cause of the decrease in percent ground cover in September and October of the second growing season $(0.55$ in $(1.40 \mathrm{~cm})$ total precipitation from August 18-September 29) (Figure 5).

Mowing was simulated across the entire plot in June 2016, May 2017, and July 2017. Mowing complied with WVDOH requirements for expressways that indicates that mowing should be completed every four weeks or as needed between May and September (WVDOH 2010b). Fenner and Palmer (1998) found that the mean number of species per unit area increased when plots were mowed monthly as opposed to being mowed once or not at all during the second growing season (3.56 species per unit area in unmown plots; 7.94 and 9.94 species per unit area in plots mowed in just June or August; 9.98 species per units area in plots mowed monthly). Low growing vegetation does not persist when high grasses are allowed to continue growth all season (Fenner and Palmer 1998).

Warm season and high elevation subplots contained many species that were not planted at the end of the second season. (Figure 9). Many forbs planted in the plot were not present in any subplot (e.g. wild bergamot, panicledleaf ticktrefoil, flat-top goldentop, and wrinkledleaf goldenrod) when analyzing ground cover by species (Table 3, Table 4). Native species alone allow too many weed or invasive species because of slow germination; non-native nonaggressive species encourage success of long-term native vegetation within mixtures, allowing less species invasion within mixtures (Holl 2002). Subplots planted with both WVDOH medians 
and WVDOH cut/full mixtures had ground cover dominated by weeping lovegrass both seasons (74.3\% and $57.0 \%$ in the second season and $72.1 \%$ and $71.4 \%$ in the third season, respectively). Weeping lovegrass is a level 3 invasive species in West Virginia, so it is inclined to spread quickly and deter other species from establishing or spreading (WVDNR 2009). Also, weeping lovegrass has a tendency to lay over creating inaccuracies in ground cover data due to collection methods.

WVDOH type D and experimental type A mixtures produced the most total biomass at the end of the second season (Figure 10). Many species that were found within the plot that were not planted can be attributed to crownvetch that was present directly outside of the plot boundary and was blown in during mowing (Figure 9). Crownvetch is listed by the WVDNR (2009) as a top level invasive species to West Virginia, so it spread throughout the entire plot and was present through both growing seasons. Japanese millet was also abundant throughout the entire plot during the second season and may have deterred some planted species from being present.

Unlike during the second growing season, there were no extended drought periods during the third growing season. The average temperature at the plot never exceeded the limit for plant growth, indicated by the growing degree day limit $\left(90^{\circ} \mathrm{F}\right)$. Although, average temperatures did extend below the growing degree day base temperature $\left(50^{\circ} \mathrm{F}\right)$ near the end of the season (Figure 5, Figure 6). Overall, there was no statistically significant difference between seed mixtures with respect to ground cover or biomass, indicating that experimental seed mixtures performed as well or better than current WVDOH mixtures during both the second and third growing season.

Ground cover of subplots planted with mowable areas mixtures had a substantial increase in species that were not contained in the mixture from the second to third growing season.

Graminoid species from WVDOH mixtures were found in subplots with experimental mowable areas mixtures, indicating invasiveness in current species contained in WVDOH mixtures.

Ground cover of species that were not planted in subplots containing experimental warm season and high elevation seed mixtures increased from the second to third growing season; ground cover by species not contained in the mixture exceeded ground cover of species that were actually planted by third growing season. Ground cover by planted species increased in subplots planted with experimental cool season mixtures from the second to the third growing season; this is due to birdsfoot trefoil establishing as most of the ground cover (Figure 9, Table 3, Figure 14, Table 4).

\subsection{2 $\mathrm{CH}-2$}

Vegetation cover was affected by winter climate conditions from the first to the second growing season as seen by the dramatic decrease in ground cover from the end of the first growing season to the beginning of the second growing season. Subplots containing experimental warm season mixtures and experimental high elevation mixtures did not perform to NPDES permit 
requirement of $70 \%$ ground cover during June, July, or September of the second growing season (Figure 19).

After simulated mowing was performed in June 2016, vegetation was reduced as seen by the decrease in ground cover from June to July (Figure 19). Decrease in ground cover could also be attributed to extreme average temperatures (daily high temperatures ranging from $68-97{ }^{\circ} \mathrm{F}(20$ $\left.36.11^{\circ} \mathrm{C}\right)$ ) and the drought period that occurred in July $(0.38$ in $(0.97 \mathrm{~cm})$ of precipitation from July 6-July 27) (Figure 17, Figure 19).

Similar to $\mathrm{CH}-1 \mathrm{~A}$, high elevation and warm season subplots contained a large percentage of species that were not present in the mixture during planting (Figure 21, Figure 26). Many forbs that were contained in the mixtures were not present at all (e.g. wild bergamot, panicledleaf ticktrefoil, flat-top goldentop, and wrinkledleaf goldenrod) (Table 6, Table 7). Red clover invaded the plot from the surrounding vegetation outside the boundary. White clover was more abundant in ground cover of subplots containing experimental mowable areas mixtures in $\mathrm{CH}-2$ than in subplots containing mowable areas mixtures any other plot; this is likely due to adequate growing conditions for white clover that could not be sustained by the graminoids in the mixture (e.g. shade, saturated soils, and cool temperatures) (Hancock and Andrae 2016). White clover is known to spread and establish over native species in West Virginia as noted by its listing as a level 3 invasive species by the WVDNR (2009).

During the third growing season, there was a large drought period in June $(0.01$ in $(0.03 \mathrm{~cm})$ of rainfall from June 7-July 4) (Figure 18). The drought period was not tolerated well, resulting in a slight decrease in percent ground cover across the plot. Following July 4, there was rain for 22 of the next 27 recorded days. Therefore, ground cover increased by August in all subplots (Figure 24). Average biomass increased in all seed mixtures from the second to the third growing season except experimental cool season (Figure 22, Figure 27). This indicates that native species continue to establish after multiple growing seasons.

\subsection{3 $\mathrm{CH}-3$}

Mowing was simulated across the entire plot on the same days as $\mathrm{CH}-1 \mathrm{~A}$. Ground cover remained above NPDES permit requirement of $70 \%$ during the entire second and third growing seasons in all subplots (Figure 31, Figure 41). There was no major difference between seed bed preparation with respect to percent ground cover during either growing season (Figure 33, Figure 34, Figure 35, Figure 43, Figure 44, Figure 45); this was supported by statistical results (Figure 35, Figure 43). However, ground cover of subplots containing experimental warm season mixtures was significantly less than ground cover of subplots planted with both WVDOH medians and experimental cool season mixtures during both the second and third growing seasons (Figure 36, Figure 46).

Birdsfoot trefoil dominated ground cover of cool season mixture subplots throughout both growing seasons, indicating invasive qualities as noted by its level 3 invasive classification by 
the WVDNR (2009). Subplots mulched with straw resulted in many weed species. Weed species decreased in subplots planted with experimental warm season mixtures from the second to the third growing season (Figure 37, Figure 47).

Precipitation was very high during the third growing season (daily rainfall reaching 2.56 in $(6.50$ $\mathrm{cm}), 1.45$ in $(3.68 \mathrm{~cm}), 1.42$ in $(3.61 \mathrm{~cm}), 1.3$ in $(3.30 \mathrm{~cm})$, and 1.23 in $(3.12 \mathrm{~cm})$ (Figure 30$)$. Therefore, there was less dead vegetation in the third growing season compared to the second growing season (Figure 37, Figure 48).

\subsubsection{CH-1B}

Mowing was simulated across the entire plot on the same occasions as $\mathrm{CH}-1 \mathrm{~A}$. Percent ground cover was above NPDES permit requirement of $70 \%$ across the entire plot at the end of the second season (Figure 51). Vegetation cover decreased from August to September likely due to high temperatures and little precipitation (Figure 5). All subplots contained over $80 \%$ planted species at the end of the second season (Figure 53). Ground cover remained above $80 \%$, exceeding the $70 \%$ goal, throughout the entire third growing season (Figure 56). Vegetation thrived from all soil amendments throughout long-term monitoring. Soil in subplots prepared with hydraulic growth mediums had higher average percent organic matter than all other subplots at the end of the second growing season (3.2\% in subplots containing Biotic Earth and $3.3 \%$ in subplots containing ProGanics compared to $2.1 \%$ in subplots prepared with topsoil and $2.1 \%$ in subplots planted in existing soil).

Plots prepared in the existing soil and using ProGanics produced the most biomass at the end of both growing seasons, but there was not a significant difference between biomass resulting from any soil amendment either season (Figure 54, Figure 55, Figure 59, Figure 60). Species that were not planted increased throughout the entire plot from the second to the third growing season, but mostly consisted of species that were planted in neighboring subplots rather than invasive weeds. Biotic Earth subplots were dominated by red fescue, while subplots containing ProGanics were abundant with hard fescue. Subplots prepared using hydraulic growth mediums retained over $50 \%$ ground cover by species that were contained in the mixture by the third growing season. Ground cover by area of species that were planted decreased in all treatments from the second to the third growing season, with the greatest decrease being $43 \%$ in subplots planted in topsoil. Similar to resulting ground cover at $\mathrm{CH}-3$, this decrease in planted species throughout topsoil plots could be due to low quality topsoil (Figure 53, Figure 58). 


\subsection{Summary and Conclusions}

Vegetation at four field plots was monitored during the second and third growing seasons after plot establishment in 2015. Each field plot had a respective specific objective as follows:

1. Compare results of experimental native and introduced seed mixtures to current WVDOH seed mixtures

2. Assess the performance of experimental high elevation seed mixtures

3. Test the use of different seed bed preparation techniques on resulting vegetation

4. Evaluate the success of using different soil amendments during planting

It is necessary to monitor vegetation over multiple growing seasons to allow full establishment of native species (Rentch et al. 2005, Skousen and Venable 2008). Invasive species impact on native vegetation can change over time, so long-term monitoring is required to adequately measure success of experimental mixtures containing native species. Invasive species have been found in many studies to decrease after initial establishment due to decreased allelopathy of the invader or native species exhibiting allelopathic resistance (Dostál et al. 2013).

Overall, results of the first objective advocate that experimental seed mixtures, aside from experimental high elevation seed mixture, performed the same or better than current WVDOH seed mixtures. The high elevation seed mixture failed to meet NPDES permit requirement of $70 \%$ ground cover in long-term monitoring and allowed weed and invasive species to establish in place of planted seeds. Mixtures demonstrated long-term resiliency when vegetation was restored after high temperature and drought periods during the second growing season. Ground cover in subplots planted with native seed mixtures contained many weed species due to slow establishment of the native species; also, many species contained in the mixture, especially forb species, did not establish at all. Experimental high elevation mixtures were removed from recommendations to the WVDOH specifications because of poor performance demonstrated at $\mathrm{CH}-2$. Subplots containing the mixture failed to meet $70 \%$ ground cover during four of the eight months that data were collected over two long-term growing seasons.

Seed bed preparation did not have a significant effect on resulting overall ground cover. Experimental cool season mixtures resulted in the highest ground cover by area and the least cover by species not contained in the mixture. Long-term vegetation results of the fourth objective at $\mathrm{CH}-1 \mathrm{~B}$ proved that hydraulic growth mediums perform as well or better than topsoil as soil amendments with respect to persistent ground cover. However, topsoil plots allowed weed or invasive species over time, so it is important to ensure quality topsoil is used during seed bed preparation. 


\subsection{Sedimentation and Runoff}

\subsection{Introduction}

Construction is one of the major causes for increased erosion because of the massive amount of disturbed land that is the result of the construction process (Muckel 2004). Although agriculture produces a greater volume of soil loss, construction sites have the highest rate of soil erosion; erosion is increased by 130 to 1000 times pre-construction conditions (Kaufman 2000; Trenouth and Gharabaghi 2015). Many pollutants are contained in sediment and runoff resulting from highways. Pollutants result from the construction process itself and vehicular traffic once the road is established ( $\mathrm{Li}$ et al. 2005). Some factors that affect erosion amounts, such as weather and topography, can change drastically by geographic location. It is critical to quantify actual sediment yield and runoff produced in different regions to effectively combat erosion (Sadeghi 2013).

The purpose of seeding a site after construction is to reduce soil erosion and runoff that is increased by the compaction of soil, loss of topsoil, and clearing of vegetation. Dense vegetation ground cover can prohibit 5\% to $40 \%$ of rainfall from coming in contact with the soil surface (Faucette et al. 2006). Plant canopy, stems, and roots all play different roles in preventing erosion, so it is necessary to ensure full vegetation establishment that could take up to two growing seasons (Rickson 2006).

Sedimentation and runoff traps were created to measure the sediment yield and runoff from four selected subplots located in $\mathrm{CH}-3$. The four subplots were all planted with experimental mowable areas seed mixture but varied in application of topsoil and type of mulch. This allowed for results to be found specifically for seed bed treatment rather than species of vegetation. The actual sediment yield calculated in the field was compared to the estimated individual storm sediment yield based on the Modified Universal Soil Loss Equation (MUSLE). The objective of this study is as follows.

- Evaluate the effectiveness of different seed bed preparation treatments (i.e. topsoil application and mulch variations) in reducing erosion by

$\circ$ Quantifying sedimentation and runoff coming from four different subplots

○ Comparing actual sediment yield to predicted sediment yield found using the MUSLE

\subsection{Background}

\subsubsection{Sedimentation and Runoff Test Plots}

\subsubsection{Effects of Soil Erosion and Runoff}

During construction, soil is compacted and topsoil is removed, discouraging the growth of vegetation. Compacting soil removes pore space needed for plant rooting and water infiltration 
(Muckel 2004). Increasing the density of soil leaves little space for vegetation roots, water, pesticides, or soil amendments to enter the soil.

Loss of topsoil results in little to no organic matter or nutrients in the soil. Microorganisms that protect the soil feed from organic matter. Without organic matter, these nutrient cycling organisms cannot survive, therefore rendering the soil less fertile. These microorganisms are responsible for enzyme transformations that are utilized by the vegetation in the soil (Kelley 1990). Topsoil is the key to soil fertility and its ability to revegetate. Organic matter increases soils water retaining capacity and ability to make nutrients available to plants (Doran et al. 1998). Organic matter helps creates a soil structure consisting of larger aggregated particles that are more resistant to erosion than soil without organic matter (Kelley 1990).

Runoff carries nutrients from soil, leaving the soil less productive for future vegetation growth. Runoff also tends to carry smaller soil particles that have water holding capacity essential for plant growth from the soil surface (Toy 2002). Over time, soil erosion creates rills in the soil surface; rills turn into small channels for runoff (Espigares et al. 2011).

Soil erosion and runoff cause environmental and water quality concerns (Soil Quality Institute 2000). When fertilizer containing nitrogen is used during the seeding process, runoff can carry nitrogen fertilizer to water bodies. Nitrogen applied through fertilizer that is not utilized by crops and plants returns to the environment. For example, nitrogen dissolved from fertilizer becomes greenhouse gasses in the form of $\mathrm{N}_{2} \mathrm{O}, \mathrm{NH}_{3}$, and $\mathrm{NO}$ (Qiao et al. 2015). Fertilizer can also produce ozone and aerosols that cause many health and environmental problems such as cancer, respiratory illnesses, and acid rain. It is suggested that nitrogen from the substantial amount of fertilizer used across the world may be contributing to a large carbon sink in the Northern Hemisphere (Gruber and Galloway 2008).

The overabundance of reactive nitrogen causes direct and indirect problems within many biogeochemical processes. Nitrogen affects other cycles of abundant atmospheric gasses as well. Increase in nitrogen in the marine ecosystems can cause eutrophication. In turn, eutrophication causes hypoxic and anoxic conditions for aquatic life by encouraging excessive growth of algae (an algal bloom) (Sills 2014).

Sedimentation adversely affects marine ecosystems in multiple ways. Sediment located in water bodies can harm fish and other living marine organisms (Davies-Colley and Smith 2001). Contaminated sediment can become harmful to feeders at the bottom of the marine food chain. Silt and clay particles also build up in spawning habitats of fish. Sedimentation causes water turbidity reducing the amount of light that can penetrate the water. Without light, marine plants cannot photosynthesize. All of these harmful qualities of sediment cause a negative bottom-up effect among entire marine ecosystems (Bartram and Ballance 1996).

Sediment retention in water sources can reduce flowrate. This can become economically costly (Soil Quality Institute 2000). Waterway erosion is a natural process that has an equilibrium. 
When extra sediment and runoff is introduced into the system, equilibrium is disturbed and the waterway responds accordingly by increasing erosion causing stream widening and flooding (Muckel 2004). Waterways must be cleaned of sediment and the toxins that can come with runoff. Sediment build-up can affect the quality or quantity of drinking or irrigation water supplies (Bartram and Ballance 1996). Lakes, reservoirs, and channels that begin to fill with sediment must be dredged for the waterways to stay useful and productive (Kelley 1990).

\subsubsection{Sediment Yield and Runoff}

Similar to this study, Benik et al. (2003) quantified sediment and runoff from different erosion control treatments used on slopes that had undergone highway construction (straw mulch, straw blanket, straw/coconut blanket, wood fiber blanket, and bare ground). Their study lasted through two growing seasons measuring ground cover and biomass through both seasons. Five storm events were used to measure runoff and sediment in the first growing season. The straw blanket and straw/coconut blanket treatments produced the most ground cover and biomass both season. Plots containing straw mulch had the least amount of measured runoff during four of the five storm events. Plots containing straw blanket had the least sediment erosion during four of the five storms. Benik et al. also observed that native grass species did not fully establish until the second growing season (Table 11).

Faucette et al. (2005) also quantified erosion from construction sites by comparing the effectiveness of soil amendments for erosion control purposes. The treatments (biosolids compost blanket with filter berm; yard trimmings compost blanket with filter berm; poultry litter compost blanket with filter berm, mulch, and gypsum blanket-2 variations percent gypsum; municipal solid waste compost and mulch blanket with filter berm; hydroseed with silt fence; hydroseed with mulch filter berm; and a bare soil control) were tested during three simulated rainfall events: one at the very beginning, one after three months of growth, and one after a year of growth. The municipal solid waste treatment produced the least runoff initially $(0.89$ in $)$ and after three months (0.07). After 12 months, the poultry litter compost treatment produced the least runoff on average (0.63 in). After one day, three months, and 12 months, the least sediment was produced by the yard-waste treatment $\left(2.1 \mathrm{lb} / \mathrm{ft}^{2}\right)$, the municipal solid wastes compost treatment $\left(0.141 \mathrm{lb} / \mathrm{ft}^{2}\right)$, and the biosolids compost treatment $\left(0.21 \mathrm{lb} / \mathrm{ft}^{2}\right)$, respectively (Table 11).

The main focus of the study done by Martínez-Zavala et al. (2008) was to quantify seasonal variation in sediment yield and runoff from bare and vegetated plots. They compared 100 simulated rainfall events from winter and summer. Martínez-Zavala et al. (2008) and Liu et al. (2016) both focused on erosion caused by unpaved roads. Liu et al. (2016) used simulated rainfall to test six vegetation treatments that varied from $3.5 \mathrm{in} / \mathrm{hr}$ of rainfall intensity to $4.7 \mathrm{in} / \mathrm{hr}$. Scouring flowrate was varied from $4.0 \mathrm{gpm}$ to $5.2 \mathrm{gpm}$ (Table 11). 
Sidhu et al. (2015) compared erosion control benefits of different seed bed preparation with and without seeds. Results indicated that all seeded treatments had better results than treatments that did not include seed $(48.9 \%$ and $68.0 \%$ runoff reduction in seeded treatments compared to bare soil and $30.3 \%, 15.6 \%$, and $45.8 \%$ runoff reduction in unseeded treatments compared to bare soil) (Table 11). 
Table 11: Previous sedimentation and runoff test plot studies

\begin{tabular}{|c|c|c|c|c|c|}
\hline Size & Objective & Description & $\begin{array}{l}\text { Type of Data } \\
\text { Collected }\end{array}$ & Results & Reference \\
\hline $\begin{array}{l}\text { Plots: } 3.94 \mathrm{ft} \text { long } \mathrm{x} \\
1.97 \mathrm{ft} \text { wide } \mathrm{x} 0.33 \mathrm{ft} \\
\text { deep }\end{array}$ & $\begin{array}{l}\text { Quantify the reduction } \\
\text { of runoff and cost } \\
\text { effectiveness of using } \\
\text { different erosion } \\
\text { control methods }\end{array}$ & $\begin{array}{l}\text { Different erosion control } \\
\text { methods: polyacrylamide; } \\
\text { wheat straw and } \\
\text { polyacrylamide (w/ and } \\
\text { w/o seed); EFM (w/ and } \\
\text { w/o seed); control was bare } \\
\text { soil }\end{array}$ & $\begin{array}{l}\text { Runoff volume; } \\
\text { turbidity; } \\
\text { average MTSS }\end{array}$ & $\begin{array}{l}\text { EFM w/ seed } \\
\text { and wheat } \\
\text { straw with } \\
\text { polyacrylamide } \\
\text { with seed had } \\
\text { highest runoff } \\
\text { reduction }\end{array}$ & $\begin{array}{l}\text { Sidhu et al. } \\
2015\end{array}$ \\
\hline $\begin{array}{l}\text { Plots: } 3 \mathrm{ft} \text { wide } \mathrm{x} 16 \\
\mathrm{ft} \text { long; Borders: } 6 \text { in } \\
\text { wide w/ } 3 \text { in buried }\end{array}$ & $\begin{array}{l}\text { Short and long-term } \\
\text { evaluation of different } \\
\text { soil amendments on } \\
\text { sediment and nutrient } \\
\text { loss }\end{array}$ & $\begin{array}{l}\text { Treatments: biosolids } \\
\text { comp; yard waste comp; } \\
\text { poultry litter comp; } \\
\text { minicipal solid waste } \\
\text { comp; soil; hydroseed w/ } \\
\text { mulch filter berm; } \\
\text { hydroseed w/ silt fence }\end{array}$ & $\begin{array}{l}\text { Runoff; solids } \\
\text { loss (sediment); } \\
\text { nutrient load in } \\
\text { runoff }\left(\mathrm{N}, \mathrm{NO}_{3} \text {, }\right. \\
\text { P) }\end{array}$ & $\begin{array}{l}\text { Compost } \\
\text { amendments } \\
\text { performed } \\
\text { same or better } \\
\text { than } \\
\text { hydroseeding } \\
\text { treatments }\end{array}$ & $\begin{array}{l}\text { Faucette et } \\
\text { al. } 2005\end{array}$ \\
\hline $\begin{array}{l}\text { Plots: } 32 \mathrm{ft} \text { long x } 4 \\
\mathrm{ft} \text { wide (wood fiber } \\
\text { blanket), x } 6.6 \mathrm{ft} \\
\text { wide (straw blanket), } \\
\mathrm{x} 8 \mathrm{ft} \text { wide (bonded- } \\
\text { fiber matrix and } \\
\text { straw/coconut } \\
\text { blanket); Borders: } 6 \\
\text { in wide w/ } 3 \text { in } \\
\text { buried }\end{array}$ & $\begin{array}{l}\text { Evaluate } 5 \text { different } \\
\text { erosion control } \\
\text { methods for } \\
\text { vegetation, runoff, and } \\
\text { sediment yield }\end{array}$ & $\begin{array}{l}3 \text { replications of } 5 \\
\text { treatments were for erosion } \\
\text { control purposes using } \\
\text { native seed mixtures }\end{array}$ & $\begin{array}{l}\text { Ground cover; } \\
\text { biomass; rainfall } \\
\text { volume and } \\
\text { intensity; } \\
\text { sediment; runoff }\end{array}$ & $\begin{array}{l}\text { First season- } \\
\text { straw mulch } \\
\text { had greatest } \\
\text { vegetation; } \\
\text { second season- } \\
\text { straw mulch } \\
\text { had least } \\
\text { amount of } \\
\text { runoff; little } \\
\text { difference in } \\
\text { sediment yield }\end{array}$ & $\begin{array}{l}\text { Benik et al. } \\
2003\end{array}$ \\
\hline $\begin{array}{l}\text { Plots: } 26.25 \mathrm{ft} \mathrm{x} \\
16.40 \mathrm{ft}\end{array}$ & $\begin{array}{l}\text { Evaluate erosion } \\
\text { control effectiveness of } \\
4 \text { different practices } \\
\text { on } 15^{\circ} \text { and } 30^{\circ} \text { fill } \\
\text { slopes after road } \\
\text { construction }\end{array}$ & $\begin{array}{l}2 \text { replications ( } 1 \text { on each } \\
\text { respective slope) of each of } \\
4 \text { treatments: natural } \\
\text { restoration; sodded strip; } \\
\text { grass \& shrub; grass }\end{array}$ & $\begin{array}{l}\text { Soil } \\
\text { characteristics; } \\
\text { root weight } \\
\text { density; root } \\
\text { length density; } \\
\text { vegetation } \\
\text { cover; runoff } \\
\text { coefficient; } \\
\text { sediment } \\
\text { concentration; } \\
\text { soil detachment } \\
\text { rate }\end{array}$ & $\begin{array}{l}\text { Grass \& shrub } \\
\text { highly } \\
\text { outperformed } \\
\text { all treatments } \\
\text { during rainfall } \\
\text { simulation; } \\
\text { Grass } \\
\text { performed best } \\
\text { under scouring } \\
\text { flow } \\
\text { conditions }\end{array}$ & $\begin{array}{l}\text { Liu et al. } \\
2016\end{array}$ \\
\hline Plots: 357.12 in $^{2}$ & $\begin{array}{l}\text { Quantify seasonal } \\
\text { variation on erosion } \\
\text { (runoff and sediment) } \\
\text { for bare and vegetated } \\
\text { backslopes of unpaved } \\
\text { forest roads }\end{array}$ & $\begin{array}{l}25 \text { bare plots; } 25 \text { vegetated } \\
\text { plots; uniform simulated } \\
\text { rainfall intensity of } 3.54 \mathrm{in} / \\
\mathrm{hr}\end{array}$ & $\begin{array}{l}\text { Soil } \\
\text { characteristics; } \\
\text { surface } \\
\text { characteristics; } \\
\text { sediment } \\
\text { concentration; } \\
\text { vegetation } \\
\text { cover; runoff } \\
\text { coefficient; soil } \\
\text { loss rate }\end{array}$ & $\begin{array}{l}\text { Soil loss is } \\
\text { greater in } \\
\text { winter; } \\
\text { vegetation and } \\
\text { OM in soil } \\
\text { reduce erosion; } \\
\text { erosion } \\
\text { exponentially } \\
\text { increases when } \\
\text { vegetation } \\
\text { cover is under } \\
20-30 \%\end{array}$ & $\begin{array}{l}\text { Martínez- } \\
\text { Zavala et al. } \\
2008\end{array}$ \\
\hline
\end{tabular}

Notes: EFM-Engineered Fiber Matrix; MTSS-Modified Total Suspended Solids; OM-Organic Matter

\subsubsection{Modified Universal Soil Loss Equation (MUSLE)}

The Modified Universal Soil Loss Equation (MUSLE) is an equation proposed by Williams and Berndt (1977) to predict sediment yield (Equation 2). The MUSLE is similar to the Universal 
Soil Loss Equation (USLE) and Revised Universal Soil Loss Equation (RUSLE), but the key difference is that the MUSLE predicts sediment yield from individual storms rather than just rainfall energy to predict annual erosion (NRCS 2006). The RUSLE is an updated version of the Universal Soil Loss Equation (USLE), which are both used to predict annual soil loss from a given area based on different factors that contribute to soil erosion. The USLE was first introduced in the 1965 USDA Handbook 282. Following the release of Handbook 282, major updates were made to the rainfall-runoff erosivity factor, as well as minor updates to other factors in the equation. In 1978, USDA Agriculture Handbook 537 was released in place of Handbook 282 and included the updated USLE, now called RUSLE (Cooper 2011).

$$
A=95\left(V_{Q} q_{p}\right)^{0.56}(K)(L)(S)(C)(P)
$$

Equation 2

Where, $A=$ soil loss per unit area (tons/acre/year)

$V_{Q}=$ volume of runoff $(\mathrm{ac}-\mathrm{ft})$

$q_{p}=$ peak flowrate (cfs)

$K=$ soil erodibility factor

$L=$ slope length factor

$S=$ slope steepness factor

$C=$ cover-management factor

$P=$ erosion control practice factor

The volume of runoff and peak flowrate are storm dependent factors that replaced the rainfallrunoff erosivity factor (R-factor) in the USLE and RUSLE (Williams and Berndt 1977). The USLE and RUSLE are not applicable to individual storm events and should only be used to predict annual sediment yield because the $\mathrm{R}$-factor is an annual average based on all rainfall events that occur in a given area in a year (Kelsey 2002). The MUSLE is considered more accurate than the USLE and RUSLE because it can be used to predict erosion from individual storm events (Zhang et al. 2009). Nearing et al. (2005) found that the percent of erosion and runoff are affected by rainfall amount and intensity more than canopy or ground cover.

The volume of runoff and peak runoff flowrate in the MUSLE can be predicted using the SoilCover-Complex or SCS Method developed by the Soil Conservation Service (Equation 3) (SCS 1957; SCS 1964). The potential retention (S) depends on a curve number (CN) ranging from 0 to 100 depending on soil and ground cover (Equation 4) (Holmes and Chintala 2012; North Carolina State University 2017). Curve numbers depend on the Hydraulic Soil Group (HSG) and cover type. HGS range from A to D for different areas depending on estimated runoff potential due to infiltration and ground cover. 


$$
Q=\frac{(P-0.2 S)^{2}}{P+0.8 S}
$$

Where, $Q=$ volume of runoff (in)

$P=24$-hour rainfall for a given storm return period (in)

$S=$ potential retention (in)

$$
S=\frac{1000}{C N}-10
$$

Equation 4

Where, $S=$ potential retention (in)

$C N=$ runoff curve number

Peak runoff flowrates predicted for rainfall events using the SCS Method utilize the predicted runoff volume (Equation 5). The equation includes a pond/swamp adjustment factor for portions of the study area that are under water. To predict peak flowrate, time of concentration must first be determined. Time of concentration is the time it takes runoff to reach the study area outlet from a point farthest away from the outlet (Hayes and Young 2006). There are many methods used to estimate time of concentration, but the SCS method often uses the SCS Segmental Method. This method considers three separate types of runoff: sheet flow, shallow concentrated flow, and channel flow (NRCS 2010).

$$
q_{p}=q_{u} A_{m} Q F_{p}
$$

Equation 5

Where, $q_{p}=$ peak flowrate (cfs)

$q_{u}=$ unit peak runoff rate $\left(\mathrm{csm} / \mathrm{in}\right.$ or $\left.\mathrm{cfs} / \mathrm{mi}^{2} / \mathrm{in}\right)$

$A_{m}=$ study area $\left(\mathrm{mi}^{2}\right)$

$Q=$ volume of runoff (in)

$F_{p}=$ pond/swamp adjustment factor

Sheet flow exists at the most remote parts of the study area and forms into shallow concentrated flow after sheet flow begins to form small gullies and rills. Channel flow occurs when sheet flow ends at depths of $0.1 \mathrm{ft}(0.0305 \mathrm{~m})$ to $0.5 \mathrm{ft}(0.152 \mathrm{~m})$. Shallow concentrated and channel/pipe flow typically develop after $100 \mathrm{ft}$ (30.48 m) (Holmes and Chintala 2012). Time of concentration for sheet flow depends on rainfall, slope, length, and Manning's roughness coefficients that have been developed for different land use and cover (Equation 6) (Well and Woodward 1986). 


$$
t_{\text {sheet flow }}=\frac{0.42(n L)^{0.8}}{P_{2}{ }^{0.5} S^{0.4}}
$$

Where, $t_{\text {sheet flow }}=$ sheet flow travel time $(\mathrm{min})$

$n=$ roughness coefficient

$L=$ flow length $(\mathrm{ft})$

$P_{2}=2$-year, 24-hour precipitation depth (in)

$S=$ slope of the surface $(\mathrm{ft} / \mathrm{ft})$

Unit peak runoff rate can be found from the ratio of initial abstraction to 24-hour precipitation for a given storm return period (Equation 7). Initial abstraction is the amount of rainfall that is lost before runoff occurs, such as from storage or vegetation. If rainfall distribution for the study area is known, coefficients have been developed by NRCS to calculate unit peak discharge using the time of concentration (Equation 8) (Moglen and Hartman 2001).

$$
\frac{I_{a}}{P}=\frac{2(100-C N)}{P(C N)}
$$

Where, $I_{a}=$ initial abstraction (in)

$P=24$-hour precipitation depth for a given return period (in)

$C N=$ curve number

$$
\log \left(q_{u}\right)=C_{0}+C_{1} \log \left(t_{c}\right)+C_{2}\left[\log \left(t_{c}\right)\right]^{2}
$$

Equation 8

Where, $q_{u}=$ unit peak discharge (csm/in)

$C_{0}, C_{1}, C_{2}=$ coefficients based on $I_{a} / P$

$t_{c}=$ time of concentration $(\mathrm{hrs})$

The remaining factors of the MUSLE (e.g. K, L, S, C, and P) are calculated using methods from the USLE or RUSLE. The soil erodibility factor depends upon the contents of the soil (e.g. organic matter content, soil characteristics) (Equation 9) (Renard et al. 1997). The particle size parameter of the soil erodibility equation depends on the silt and clay composition of the soil (Equation 10). Wischmeier et al. (1971) created a nomograph to predict K factors. 


$$
\begin{array}{cr}
K=\left[\left(2.1 \times 10^{-6}\right)\left(f_{p}^{1.14}\right)\left(12-P_{\text {om }}\right)+(0.0325)\left(S_{\text {struc }}-2\right)+(0.025)\left(f_{\text {perm }}-3\right)\right] & \text { Equation 9 } \\
f_{p}=P_{\text {silt }}\left(100-P_{\text {clay }}\right) & \text { Equation 10 }
\end{array}
$$

Where, $K=$ soil erodibility factor

$f_{p}=$ particle size parameter

$P_{o m}=$ percent organic matter

$S_{\text {struc }}=$ soil structure index

$f_{\text {perm }}=$ profile-permeability class factor

$P_{\text {clay }}=$ percent clay

$P_{\text {silt }}=$ percent silt

The USDA textural triangle can also be used to classify soil using the soil's percent clay, sand, and silt. Once the textural class of the soil is identified, tables, such as those established by Stewart et al. (1975), Mitchell and Bubenzer (1980), and Schwab et al. (1981), can be used to identify the soil erodibility factor.

The slope length factor depends on the horizontal projected length of the slope (Equation 11) (Wischmeier and Smith 1978). The variable slope length exponent depends on the ratio of rill to interill erosion (Renard et al. 1994a). Typical values were developed by Wischmeier and Smith (1978) and McCool et al. (1989) that depend on the percent slope of the study area. The slope steepness factor can be calculated for slopes shorter than $15 \mathrm{ft}$ (4.57 m) using the percent slope. The significance of the rill to interrill erosion is also considered in the slope steepness factor (Equation 12) (Renard et al. 1997).

$$
L=\left(\frac{\lambda}{72.6}\right)^{m}
$$

Equation 11

Where, $L=$ slope length factor

$\lambda=$ slope length

$m=$ variable slope length exponent

$$
S=3.0(\sin \theta)^{0.8}+0.56
$$

Equation 12

Where, $S=$ slope steepness factor

$$
\theta=\text { angle of slope }\left(^{\circ}\right)
$$

Four tables have been developed based on preceding equations that can be used to find the LS factor for an area. The four different tables are based on the ratio of rill to interrill erosion, ranging from low to high, and one table for thawing soils. Incorporation of rill to interrill erosion was one update from the USLE to RUSLE (Renard et al. 1997).

The cover-management factor depends on the prior land use, canopy cover, surface cover, surface roughness, and the soil moisture. This factor ranges from 0 to 1.5 with smaller factors representing superior protection from soil erosion (e.g. highly vegetated) (Equation 13) (Renard et al. 1994b; Renard et al. 1997). 


$$
C=(P L U)(C C)(S C)(S R)(S M)
$$

Equation 13

Where, $C=$ cover-management factor

$P L U=$ prior land use

$C C=$ crop canopy

$S C=$ surface/ground cover

$S R=$ surface roughness

$S M=$ soil moisture

Various tables have been created utilizing these four factors to estimate the cover-management factor (Wischmeier 1978; Shen and Julien 1993; Renard et al. 1997). The support practice factor is affected by different erosion control practices such as contouring, terracing, and subsurface drainage (Renard et al. 1997).

\subsection{Methods}

\subsubsection{Sediment and Runoff Subplot Selection}

All factors that affect MUSLE were considered in this study. Estimated sediment yield was compared to the actual sediment yield calculated in the field for different seed bed preparations using developed $4.5 \mathrm{ft}$ x $4.5 \mathrm{ft}(1.37 \mathrm{~m}$ x $1.37 \mathrm{~m})$ sediment and runoff trapping apparatuses. Four treatments were tested for effectiveness of seed bed preparation on erosion control. All four testing subplots contained the same seed mixture. Two of the seed beds contained topsoil while the other two were planted in existing soil. Two of the subplots contained straw mulch while two were prepared using hydraulic erosion control product (Figure 61). 


\begin{tabular}{|c|c|c|c|c|c|}
\hline $\begin{array}{l}\text { Developed } \\
\text { Type B } \\
(\mathrm{TS}, \mathrm{HP}, 1)\end{array}$ & $\begin{array}{l}\text { WVDOH } \\
\text { Type B } \\
(\mathrm{NTS}, \mathrm{S}, 1)\end{array}$ & $\begin{array}{l}\text { Developed } \\
\text { Type B } \\
(T S, S, 1)\end{array}$ & $\begin{array}{l}\text { Developed } \\
\text { Type C } \\
\text { (NTS, S, 2) }\end{array}$ & $\begin{array}{l}\text { Developed } \\
\text { Type C } \\
(\mathrm{NTS}, \mathrm{HP}, 1)\end{array}$ & $\begin{array}{l}\text { Developed } \\
\text { Type B } \\
\text { (NTS, HP, 2) }\end{array}$ \\
\hline $\begin{array}{l}\text { Developed } \\
\text { Type B } \\
(T S, S, 2)\end{array}$ & $\begin{array}{l}\text { WVDOH } \\
\text { Type B } \\
\text { (TS, S, 1) }\end{array}$ & $\begin{array}{l}\text { WVDOH } \\
\text { Type B } \\
\text { (NTS, HP, 2) }\end{array}$ & $\begin{array}{l}\text { Developed } \\
\text { Type B } \\
(\mathrm{TS}, \mathrm{HP}, 2)\end{array}$ & $\begin{array}{l}\text { Developed } \\
\text { Type B } \\
(\mathrm{NTS}, \mathrm{HP}, 1)\end{array}$ & $\begin{array}{l}\text { Developed } \\
\text { Type B } \\
\text { (NTS, S, 2) }\end{array}$ \\
\hline (x) & $\begin{array}{l}\text { Developed } \\
\text { Type C } \\
(\text { NTS, HP, 2) }\end{array}$ & 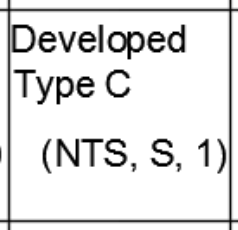 & $\begin{array}{l}\text { WVDOH } \\
\text { Type B } \\
(\mathrm{TS}, \mathrm{HP}, 2)\end{array}$ & $\begin{array}{l}\text { Developed } \\
\text { Type C } \\
(\mathrm{TS}, \mathrm{HP}, 1)\end{array}$ & (xype,s: \\
\hline 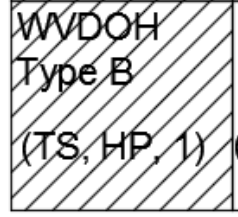 & $\begin{array}{l}\text { Developed } \\
\text { Type C } \\
(\mathrm{TS}, \mathrm{HP}, 2)\end{array}$ & $\begin{array}{l}\text { Developed } \\
\text { Type C } \\
(\mathrm{TS}, \mathrm{S}, 2)\end{array}$ & $\begin{array}{l}\text { Developed } \\
\text { Type C } \\
(T S, S, 1)\end{array}$ & $\begin{array}{l}\text { Developed } \\
\text { Type B } \\
(\text { NTS, S, 1) }\end{array}$ & 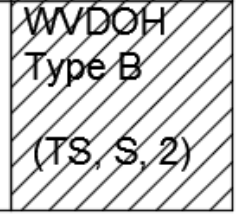 \\
\hline
\end{tabular}

Figure $61 \mathrm{CH}-3$ sedimentation and runoff trap subplot locations (identified with hatching)

\subsubsection{Sediment and Runoff Trap Design}

Sediment and runoff traps were pre-constructed in the laboratory before being installed in the field to collect data (Figure 62). Methods for design of the sedimentation and runoff traps were adapted from the National Research Project for Simulated Rainfall-Surface Runoff Studies (2004), Faucette et al. (2005), and Sidhu et al. (2015).

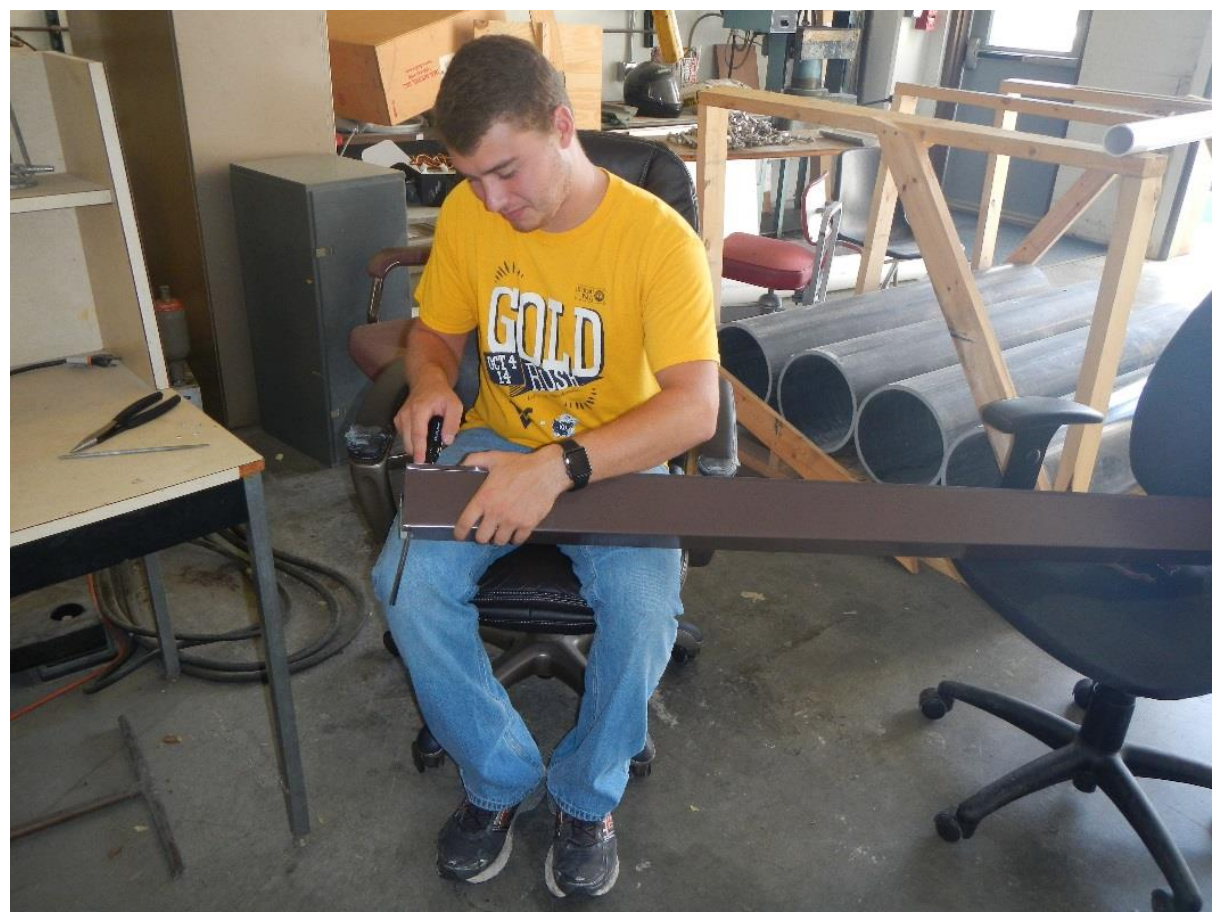

Figure 62: Pre-construction of sedimentation/runoff collection troughs in lab 
Corrugated metal was cut to be used as the barricade around each subplot, similar to that used in Faucette et al. (2005), to prevent runoff from surrounding subplots from entering the test subplot. Pieces were cut so that a three-sided border measuring $4.5 \mathrm{ft}(1.37 \mathrm{~m})$ on each side could be installed in the field. Four covered collection troughs were created using rain gutter, such as those created in similar studies (Benik 2003; Martínez-Zavala 2008). The troughs were covered with gutter cover that contained runoff and sediment collection holes on only the front to prevent direct rainfall from entering the collection gutters. The ends of the collection troughs were sealed with gutter end caps (Figure 63; Figure 64; Figure 65)

PVC pipes were designed to direct the runoff and sediment from the collection gutters to storage containers. Two in $(5.08 \mathrm{~cm})$ holes were cut into each storage container and collection gutter to insert PVC pipes that were cut in the field. Each storage container was covered with rolled wire that was staked into the ground to prevent the containers from being pushed up by pore pressure. Subplots WVDOH type B (TS, HP, 1) and WVDOH type B (TS, S, 2) were designed with storage containers located directly in front of the collection gutter connected with a straight PVC pipe (Figure 63). 


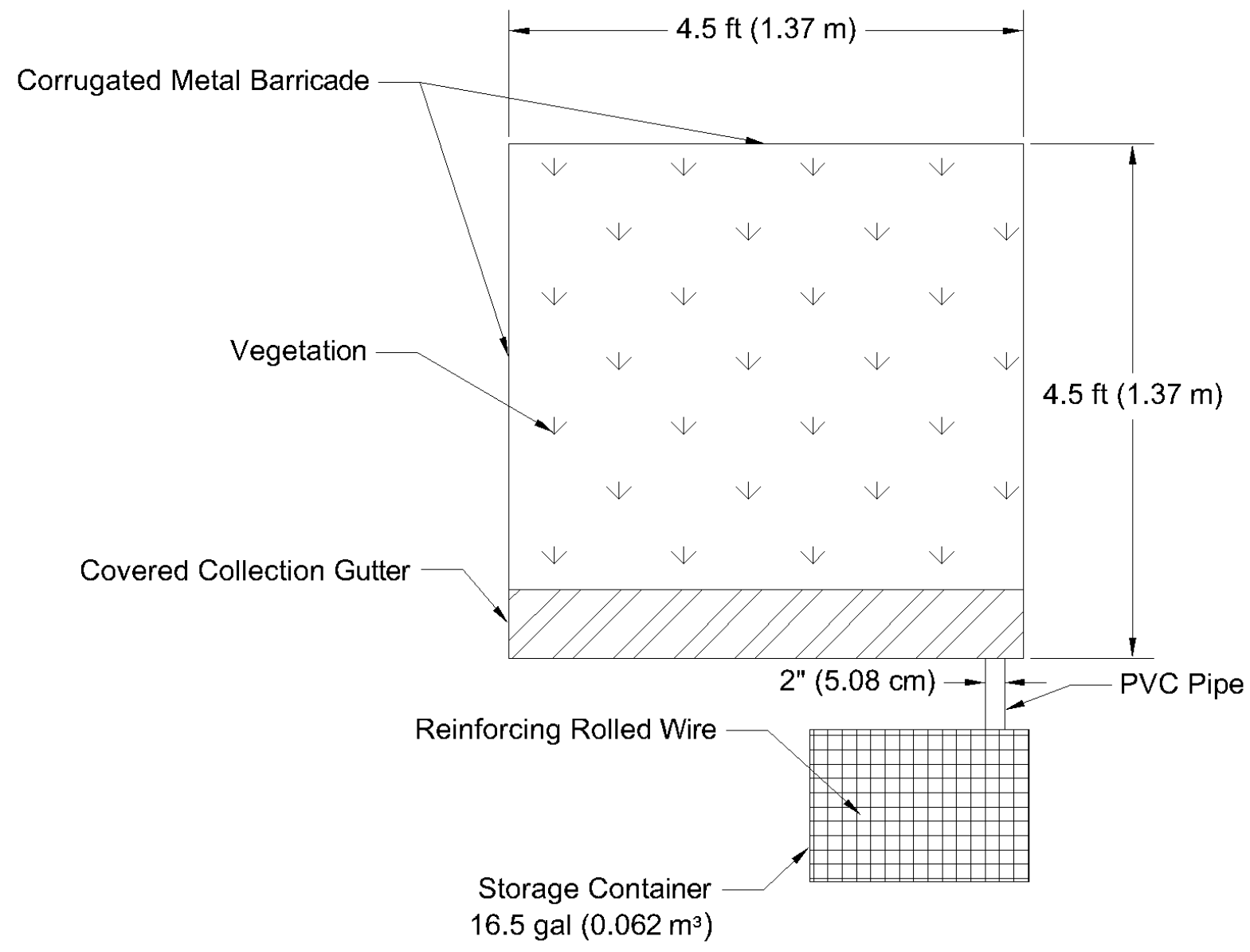

Figure 63: CH-3 WVDOH type B (TS, HP, 1) and WVDOH type B (TS, S, 2) sedimentation and runoff subplot collection apparatus

Subplot WVDOH type B (NTS, HP, 1) was designed with a collection gutter that drained from the side into a straight pipe leading to the storage container. A ramp made from vinyl siding was created inside of the gutter to counter the side slope and direct runoff and sediment to the storage container (Figure 64). Subplot WVDOH type B (NTS, S, 2) was designed so that sediment and runoff drained through a pipe containing a $90^{\circ}$ elbow to a storage container located on the side of the trap (Figure 65). Plastic $16.5 \mathrm{gal}\left(0.16 \mathrm{~m}^{3}\right)$ storage containers with lids were used to collect sediment and runoff. Each storage container was labeled every $10 \mathrm{qt}\left(9464 \mathrm{~cm}^{3}\right)$ so a rough volume of sedimentation and runoff could be identified during field visits (Figure 66). All parts of the collection apparatuses were caulked to prevent any outside sediment or runoff from entering the systems. 


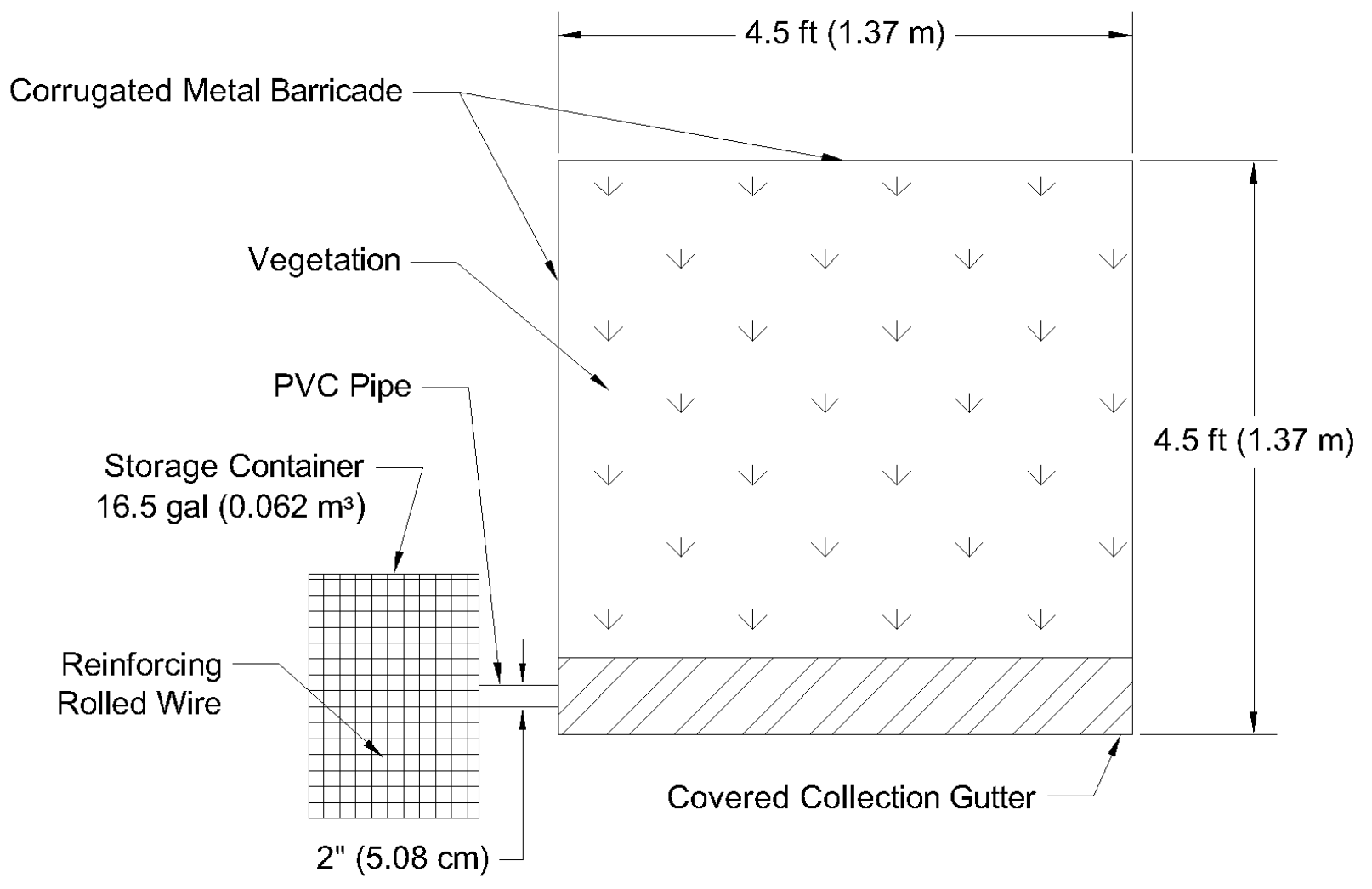

Figure 64: CH-3 WVDOH type B (NTS, HP, 1) sedimentation and runoff subplot collection apparatus 


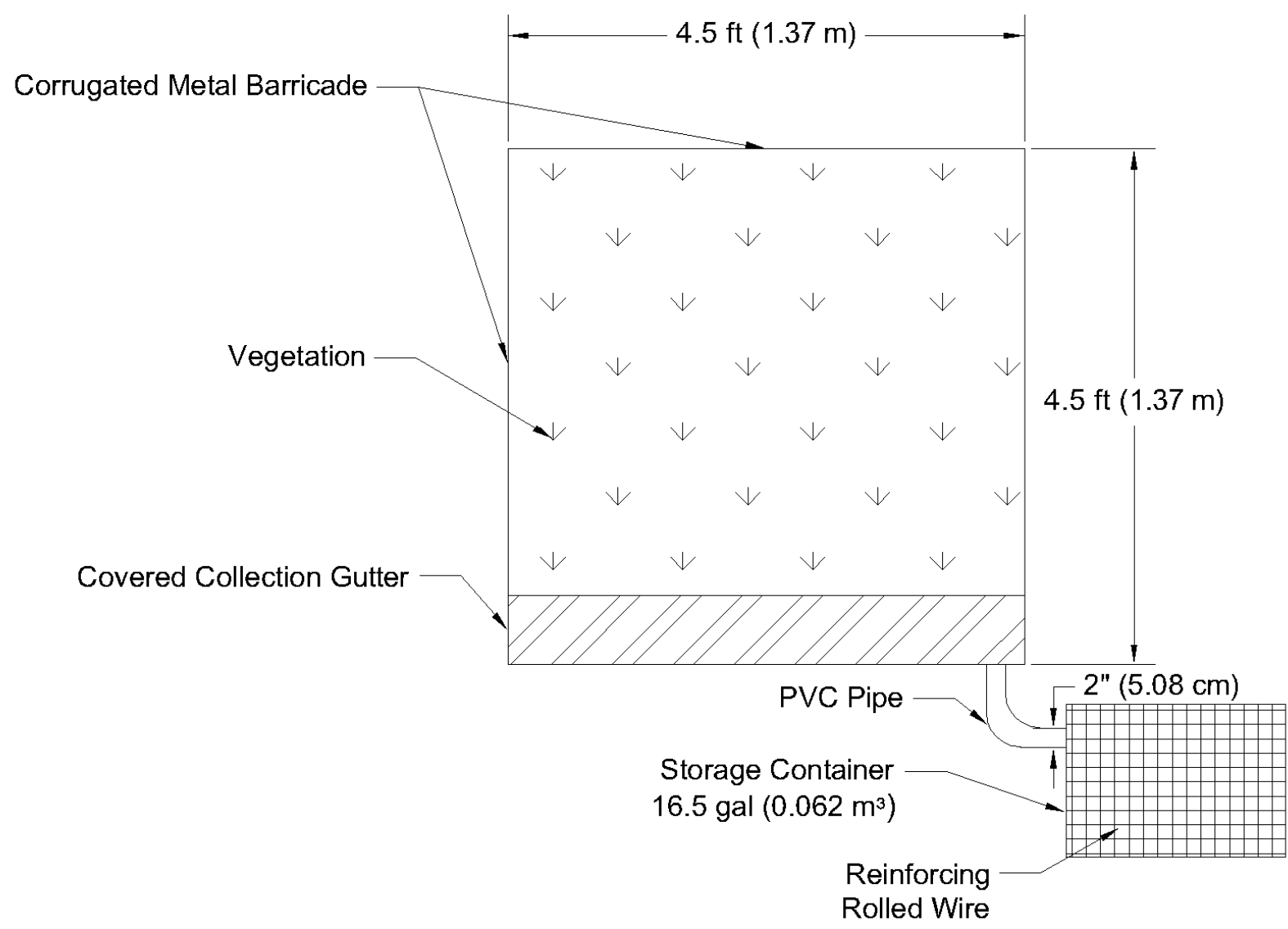

Figure 65: CH-3 WVDOH type B (NTS, S, 2) sedimentation and runoff subplot collection apparatus

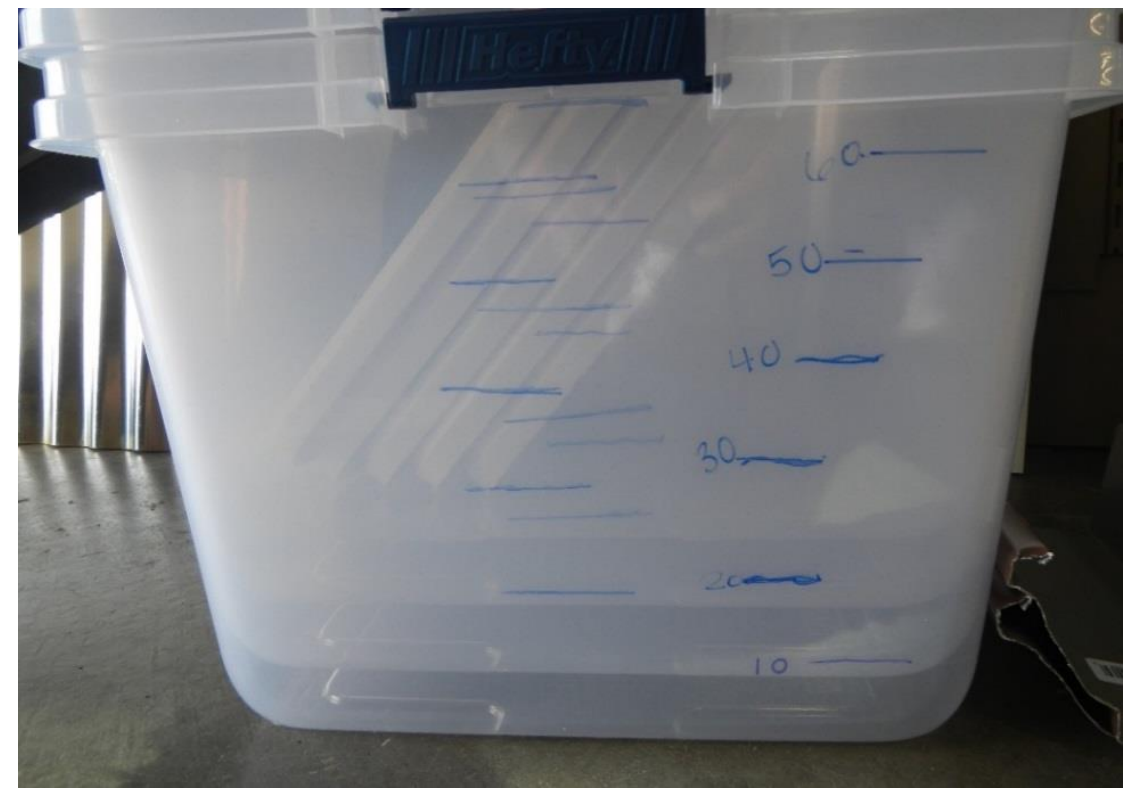

Figure 66: Runoff and sedimentation storage containers with volume labels 


\subsubsection{Sedimentation and Runoff Trap Installation}

On July 28, 2016, the first trap was installed into plot $\mathrm{CH}-3$ as a trial run to ensure proper installation and configure the system as needed. The subplot chosen for the trial was WVDOH type B (TS, HP, 1). Approximately 4 in $(10.16 \mathrm{~cm})$ of pre-cut corrugated metal sheeting was inserted into the ground, while 5 in $(12.7 \mathrm{~cm})$ remained as a barrier above the surface. A trench for the collection gutter was created so that the gutter could be installed at the downslope end of the subplot. The gutter was installed so that the bottom of the holes cut out of the gutter cover were flush with the ground (Figure 67). 


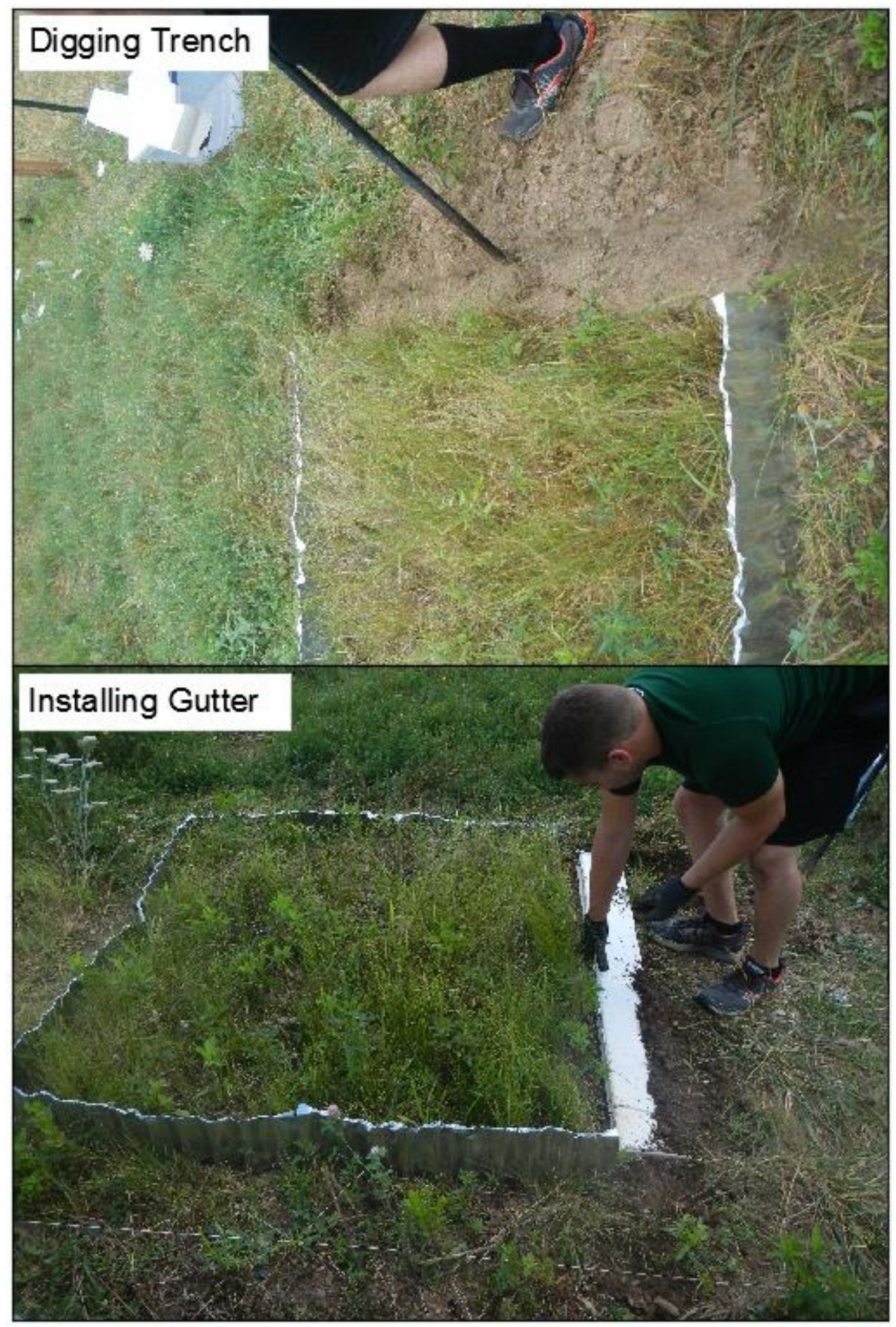

Figure 67: Installation of test sedimentation and runoff collection gutter

Due to a rain delay, the trial sedimentation and runoff collection apparatus installation was finished on August 4, 2016. During this visit, the hole for the storage container was dug and the container was installed at a depth so that the lid was still above ground but the PVC pipe 
connecting the container and collection trough was sloping downward. The collection gutter and storage container were backfilled with soil to ensure secure installation. The pre-cut PVC pipe was then installed into the holes cut out of the gutter and container. All pieces of the apparatus were then caulked together (Figure 68). 


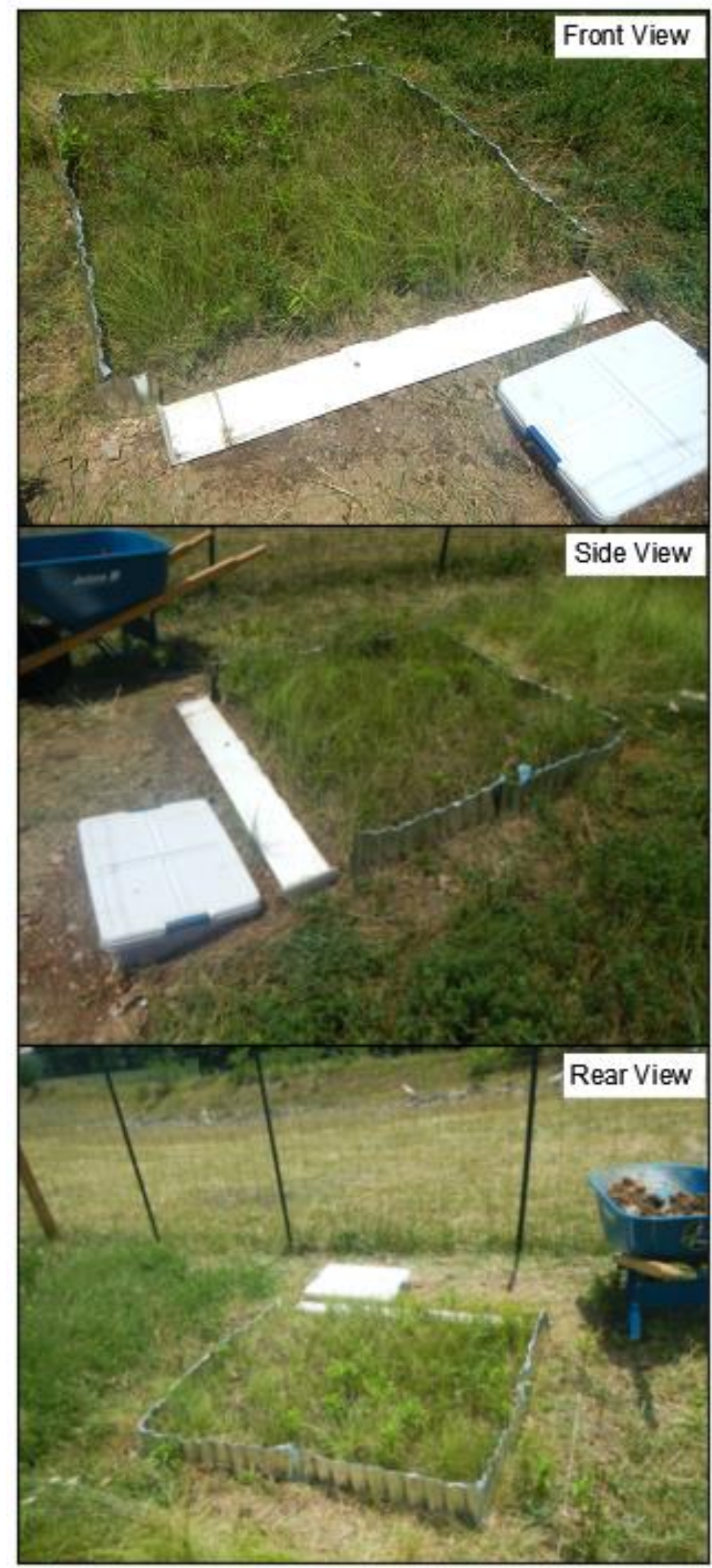

Figure 68: All angle views of trial sedimentation and runoff apparatus 
On May 16, 2017 three other sedimentation and runoff collection apparatuses were installed into the remaining three test subplots. The installation process followed that of the trial apparatus. Following the initial installation, updates were made to the traps; rolled cage was installed over the storage containers and landscape edging was installed around the container holes to prevent water from filling the holes and pushing the containers (Figure 69, Figure 70, Figure 71, Figure 72, Figure 73).

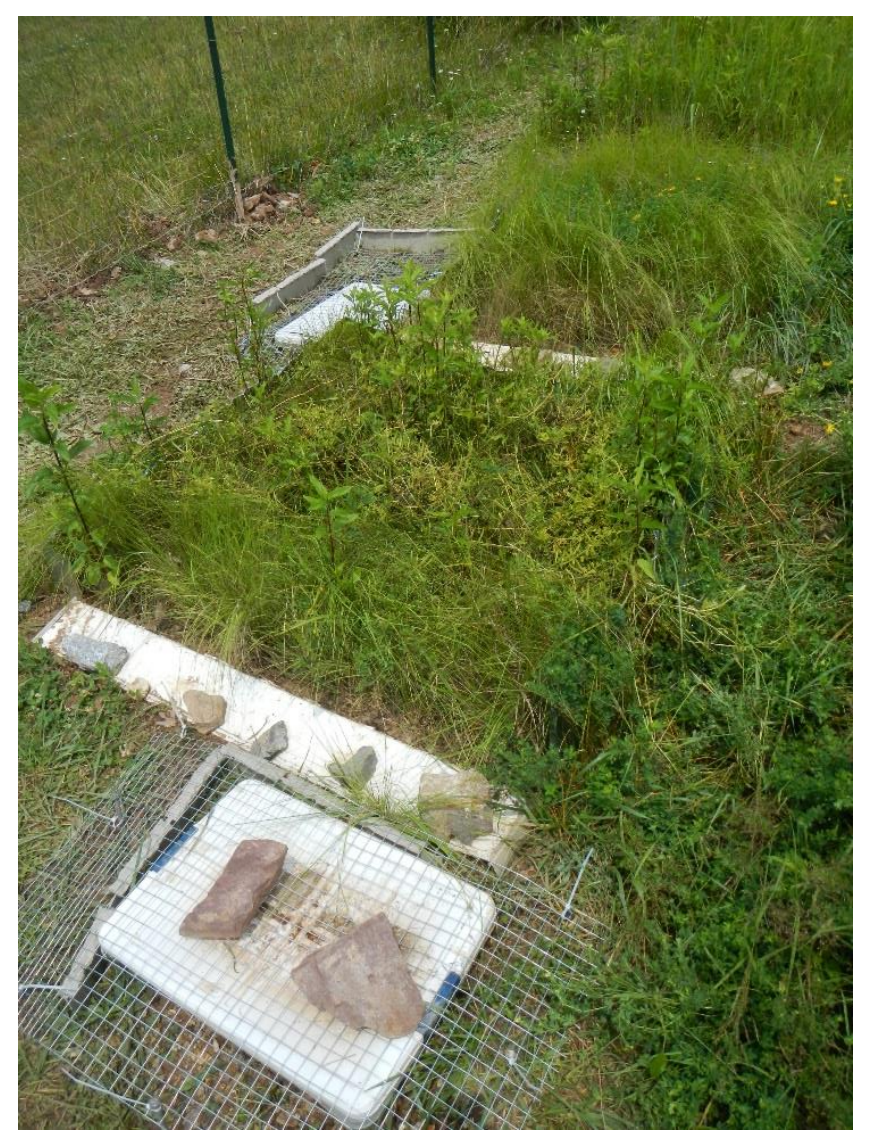

Figure 69: CH-3 WVDOH type B (NTS, HP, 1) and (TS, HP, 1) front view of sedimentation collection apparatuses 


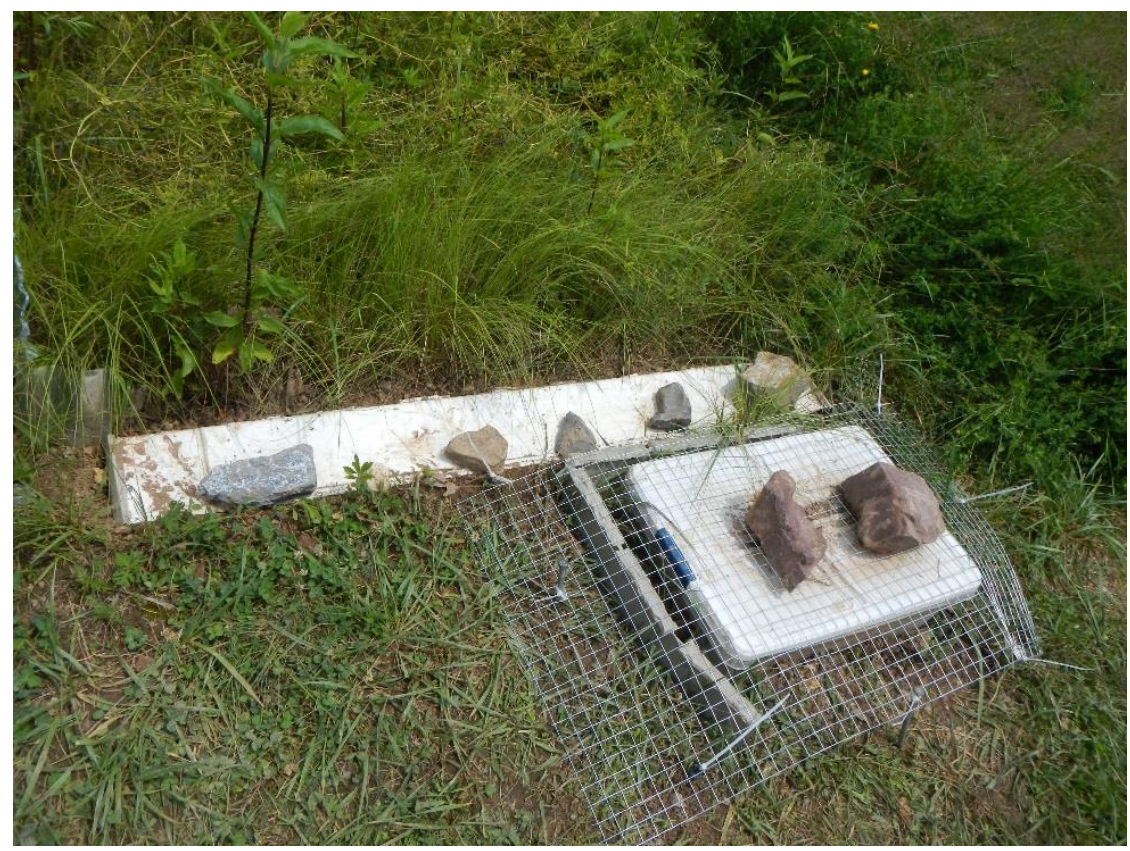

Figure 70: CH-3 WVDOH type B (TS, HP, 1) collection gutter and storage container with rolled wire reinforcement

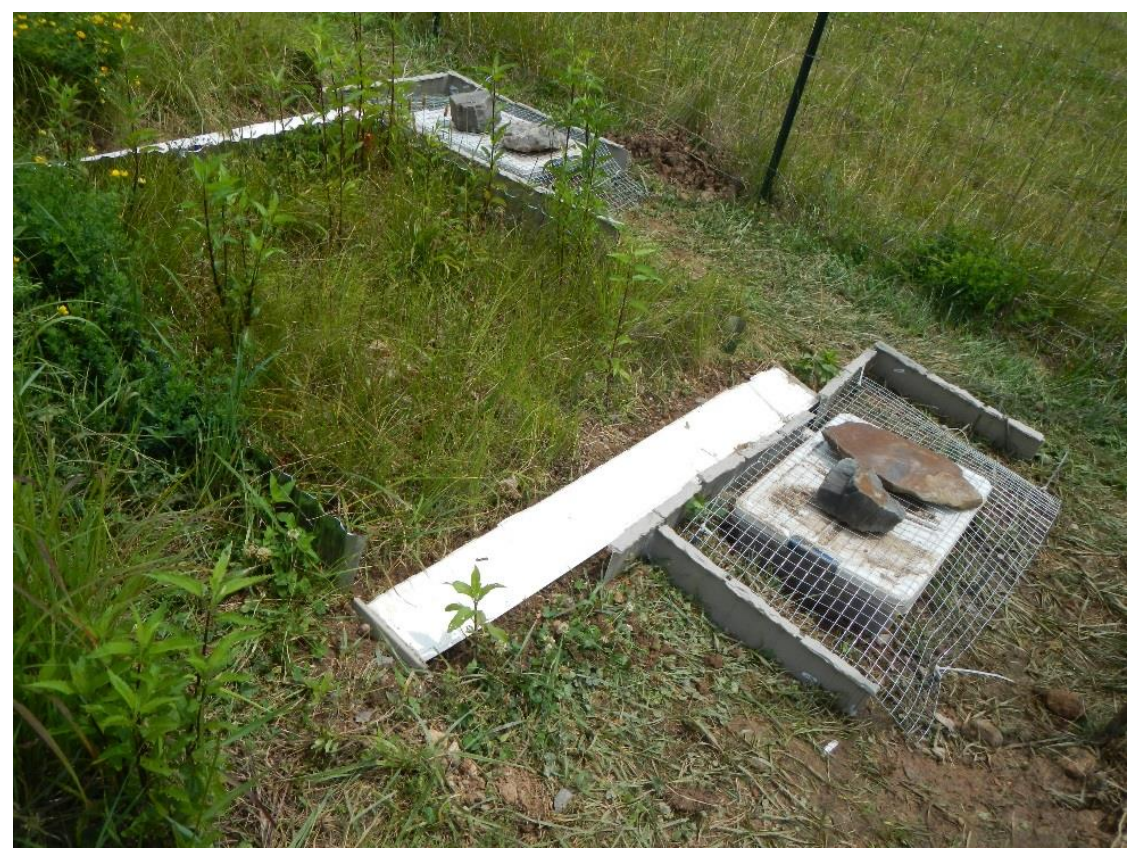

Figure 71: CH-3 WVDOH type B (NTS, S, 2) and (TS, S, 2) left view of sedimentation collection apparatuses 


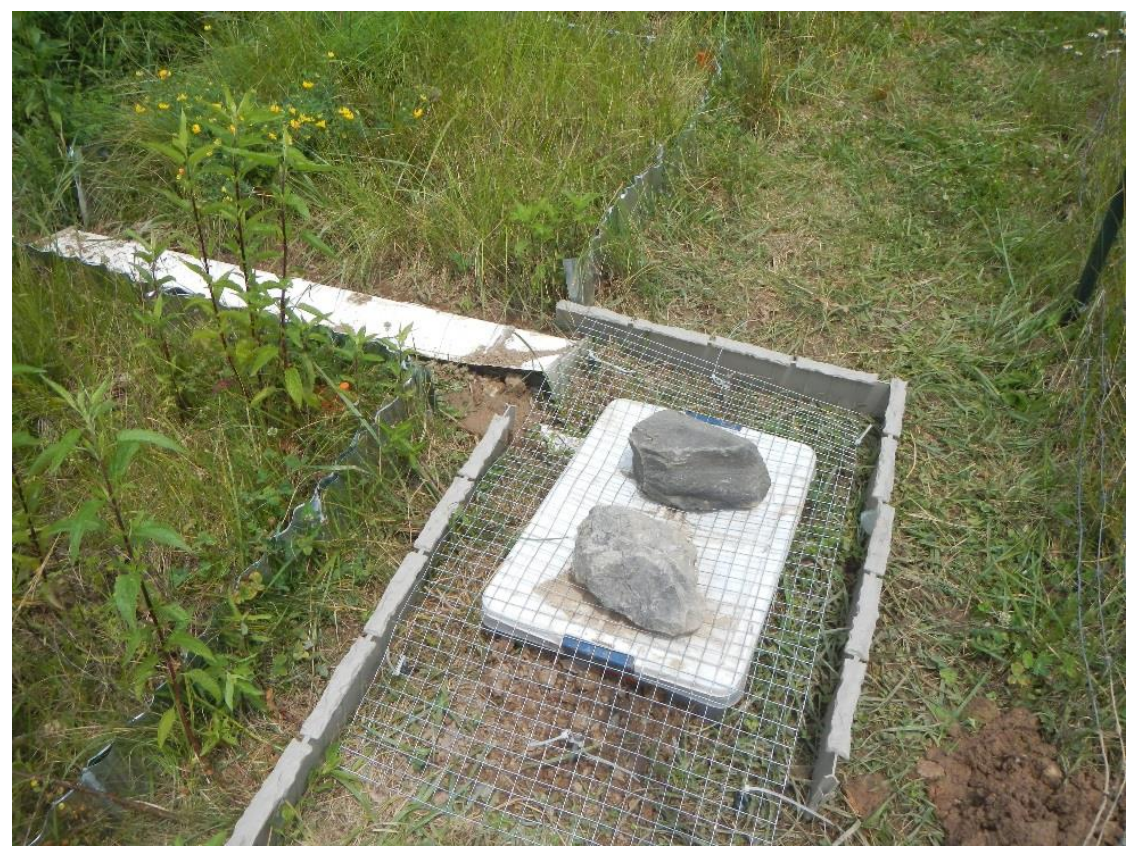

Figure 72: CH-3 WVDOH type B (NTS, S, 2) sediment and runoff collection apparatus

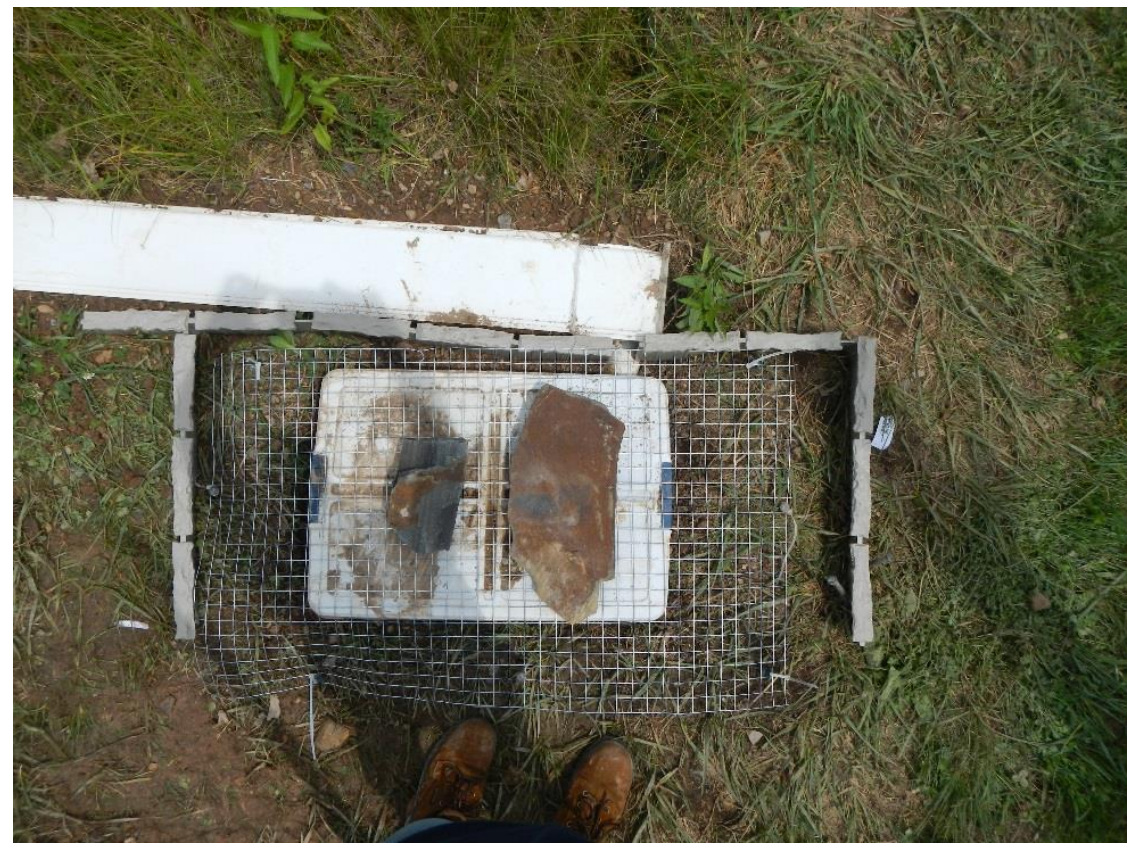

Figure 73: CH-3 WVDOH type B (TS, S, 2) sediment and runoff collection apparatus

Runoff and sediment samples were collected from each storm event and analyzed by the West Virginia University National Research Center for Coal and Energy Analytical Laboratory for total suspended solids, phosphorus, iron, phosphate, nitrate, and ammonia contents.

\subsubsection{MUSLE Factors}

MUSLE was used to estimate sediment yield from multiple storms throughout the 2017 growing season. The hydrologic soil group for the study area was determined by the NRCS "Web Soil 
Survey" (2016). The hydrologic soil group for the study area is D, which reflects low infiltration rates. Infiltration rate of the soil was recorded in the field using a Turf-Tec International Double Ring Infiltrometer. The study area was considered to be a fully developed urban area equivalent to a pasture with established vegetation in good condition (ground cover $>75 \%$ ), resulting in a curve number of 80 (Holmes and Chintala 2012). Potential retention was estimated as 2.5 in $(6.35 \mathrm{~cm})$ (Equation 4).

For estimation purposes, a 1-year 24-hour storm was assumed when calculating total runoff volume because this was similar to the storm data actually collected in the field (CWP 2012). According to NOAA's Precipitation Frequency Data Server (PFDS), precipitation depth for a 1year, 24-hour storm at $\mathrm{CH}-3$ is 2.90 in $(7.36 \mathrm{~cm})$. SCS Method resulted in atal runoff volume of 0.62 in $(1.57 \mathrm{~cm})$ for each subplot (Equation 3). Taking into account the total area of each subplot, estimated total runoff volume for each subplot was $2.39 \times 10^{-5}$ ac-ft $\left(2.95 \times 10^{-6}\right.$ ha-m).

To calculate sheet flow time of concentration, a Manning's Roughness coefficient of 0.15 was used for short grass (North Carolina State University 2017). The dimensionless slope of the surface was 0.154 . The flow length was $4.5 \mathrm{ft}(1.37 \mathrm{~m})$. NOAA's PFDS calculated precipitation depth for a 2-year, 24-hour rainfall event in the study area as 2.68 in $(6.81 \mathrm{~cm})$. Resulting sheet flow travel time was $0.353 \mathrm{~min}$ (Equation 6). The ratio of initial abstraction to precipitation for a 1-year, 24-hour storm was estimated to be 0.240 (Equation 7). Using time of concentration and the ratio of initial abstraction to estimated precipitation and its corresponding NRCS coefficients, the unit peak discharge was estimated to be $1667.79 \mathrm{csm} /$ in (Equation 8). With all factors calculated, peak flowrate for each subplot was estimated to be $7.47 \times 10^{-4} \mathrm{ft}^{3} / \mathrm{s}\left(2.12 \times 10^{-5} \mathrm{~m}^{3} / \mathrm{s}\right)$ (Equation 5).

The soil erodibility factor for all subplots was determined based upon laboratory tests that revealed the contents of the soil at the beginning of Phase 1. The properties of the soil in CH-3 are as follows: $32.8 \%$ clay, $42.2 \%$ sand, and $24.8 \%$ silt. According to the USDA textural triangle (Soil Conservation Service 1987), the soil in CH-3 is classified as clay loam. The soil test in Phase 1 also revealed that $\mathrm{CH}-3$ has an organic matter content of $1.0 \%$. Using the textural class and percent organic matter, the $\mathrm{K}$ factor was identified as approximately 0.27 (Schwab et al. 1981).

The subplots have a slope length of $4.5 \mathrm{ft}(1.37 \mathrm{~m})$ and percent slope of $15.4 \%$. These characteristics coupled with high vegetation cover result in an LS factor of 0.72 (Renard et al. 1997). Cover-management factors were chosen based on a table created by Shen and Julien (1993). All subplots contained grass-like vegetation with no appreciable canopy. Subplots WVDOH type B (NTS, HP, 1), WVDOH type B (TS, HP, 1), and WVDOH type B (NTS, S, 2) all had average ground cover above $95 \%$. The resulting $C$ factor for these subplots was 0.003 . The remaining subplot WVDOH type B (TS, S, 2) had an average ground cover between 80 and 95 Because there are no erosion control practices used in the plot, the $\mathrm{P}$ factor for all four subplots is 1.0 (Renard et al. 1997). 


\subsection{Results}

\subsubsection{Trial Sedimentation and Runoff Trap}

Results were recorded from the first runoff collection trap installed in 2016 to assess whether three more traps should be installed for a full experiment in 2017. On Tuesday, August 9, 2016, the results of the trial sedimentation and runoff trap from the first storm event were observed. Approximately $1.00 \mathrm{ft}^{3}\left(0.0284 \mathrm{~m}^{3}\right)$ of runoff was contained in the storage container. During the time period between installation and observation, 1.65 in $(4.19 \mathrm{~cm})$ of rain was recorded by the rain gauge located at plot $\mathrm{CH}-3$ (Figure 29). The resulting rain volume over the subplot was 2.78 $\mathrm{ft}^{3}\left(0.0786 \mathrm{~m}^{3}\right)$. The runoff coefficient for this storm event was 0.36 .

\subsubsection{Runoff}

The storm event occurring in 2016 between June 22 and June 26 resulted in runoff collected by the trap located at subplot WVDOH type B (TS, S, 2). Precipitation total was 0.91 in $(2.31 \mathrm{~cm})$. Volume of runoff contained in the storage container was approximately $0.738 \mathrm{ft}^{3}\left(0.021 \mathrm{~m}^{3}\right)$. The runoff coefficient for this storm event was 0.48 , increasing from the coefficient resulting from the storm runoff collected in the trial runoff trap in 2016. Three samples were tested for total suspended solids resulting in an average of $1598 \pm 27 \mathrm{mg} / \mathrm{L}\left(0.0136 \pm 2.25 \times 10^{-4} \mathrm{lb} / \mathrm{gal}\right)$ (Table 12).

Total rainfall from August 3 until August 7, 2016 was 0.5 in $(1.27 \mathrm{~cm})$. Peak precipitation occurred on August 7 from 6 am until 11 am $(0.28$ in $(0.71 \mathrm{~cm}))$. Storage containers contained no runoff, so all rainfall was assumed to have infiltrated. Therefore, runoff samples could not be analyzed (Table 12).

Table 12: Runoff test subplots sample analysis results

\begin{tabular}{|c|c|c|c|c|c|c|c|}
\hline Date & Subplot & $\begin{array}{c}\text { TSS mg/L } \\
\text { (lb/gal) }\end{array}$ & $\begin{array}{c}\text { Fe mg/L } \\
\text { (lb/gal) }\end{array}$ & $\begin{array}{c}\text { P mg/L } \\
\text { (lb/gal) }\end{array}$ & $\begin{array}{c}\text { PO4 mg/L } \\
\text { (lb/gal) }\end{array}$ & $\begin{array}{c}\text { NO3 } \\
\text { uS/cm } \\
\text { (uS/in) }\end{array}$ & $\begin{array}{c}\text { NH3 mg/L } \\
\text { (lb/gal) }\end{array}$ \\
\hline $\begin{array}{l}6 / 22 / 17- \\
6 / 26 / 17\end{array}$ & $\begin{array}{c}\text { WVDOH } \\
\text { Type B } \\
(\mathrm{TS}, \mathrm{S}, 2)\end{array}$ & $\begin{array}{c}1598 \pm 27 \\
(0.0136 \pm \\
\left.2.25 \times 10^{-4}\right)\end{array}$ & $\begin{array}{c}2.538 \\
\left(2.12 \times 10^{-5}\right)\end{array}$ & $\begin{array}{c}0.568 \\
\left(4.74 \times 10^{-6}\right)\end{array}$ & $\begin{array}{c}1.741 \\
\left(1.45 \times 10^{-5}\right)\end{array}$ & $\begin{array}{l}20.148 \\
(51.18)\end{array}$ & $\begin{array}{c}0.01 \\
\left(8.35 \times 10^{8}\right)\end{array}$ \\
\hline $\begin{array}{c}\text { 8/3/17- } \\
\text { 8/7/17 }\end{array}$ & $\mathrm{n} / \mathrm{a}$ & $\mathrm{n} / \mathrm{a}$ & $\mathrm{n} / \mathrm{a}$ & $\mathrm{n} / \mathrm{a}$ & $\mathrm{n} / \mathrm{a}$ & $\mathrm{n} / \mathrm{a}$ & $\mathrm{n} / \mathrm{a}$ \\
\hline
\end{tabular}

Note: $\mathrm{n} / \mathrm{a}$ is used where no runoff resulted from storm events; iron concentration after mixing was 0.36 $\mathrm{mg} / \mathrm{L}\left(3.00 \times 10^{-6} \mathrm{lb} / \mathrm{gal}\right)$

\subsubsection{Sediment Yield}

Sediment yield was recorded from actual storm events in the field and compared to predicted sediment yield using the MUSLE. Average resulting measured infiltration rate of the soil was 
$0.4113 \mathrm{in} / \mathrm{hr}(1.045 \mathrm{~cm} / \mathrm{hr})$, reflecting a loam soil (NRCS 2008). Estimated sediment yield from each of the four test plots was $4.23 \times 10^{-6}$ tons/ac $\left(9.48 \times 10^{-6}\right.$ tonnes/ha) (Table 13).

Table 13: MUSLE sediment yield results

\begin{tabular}{|c|c|c|c|c|}
\hline Plot & $\begin{array}{c}\text { WVDOH Type B } \\
(\mathrm{NTS}, \mathrm{HP}, \mathbf{1})\end{array}$ & $\begin{array}{c}\text { WVDOH Type B } \\
(\mathrm{TS}, \mathrm{HP}, \mathbf{1})\end{array}$ & $\begin{array}{c}\text { WVDOH Type B } \\
\text { (NTS, S, 2) }\end{array}$ & $\begin{array}{c}\text { WVDOH Type B } \\
(\mathrm{TS}, \mathrm{S}, 2)\end{array}$ \\
\hline $\begin{array}{l}\mathrm{V}_{\mathrm{Q}} \mathrm{ac}-\mathrm{ft} \\
(\mathrm{ha}-\mathrm{m})\end{array}$ & $\begin{array}{c}2.39 \times 10^{-5} \\
\left(2.95 \times 10^{-6}\right)\end{array}$ & $\begin{array}{c}2.39 \times 10^{-5} \\
\left(2.95 \times 10^{-6}\right)\end{array}$ & $\begin{array}{c}2.39 \times 10^{-5} \\
\left(2.95 \times 10^{-6}\right)\end{array}$ & $\begin{array}{c}2.39 \times 10^{-5} \\
\left(2.95 \times 10^{-6}\right)\end{array}$ \\
\hline $\begin{array}{l}\mathrm{q}_{\mathrm{p}} \mathrm{ft}^{3} / \mathrm{s} \\
\left(\mathrm{m}^{3} / \mathrm{s}\right)\end{array}$ & $\begin{array}{c}7.47 \times 10^{-4} \\
\left(2.12 \times 10^{-5}\right)\end{array}$ & $\begin{array}{c}7.47 \times 10^{-4} \\
\left(2.12 \times 10^{-5}\right)\end{array}$ & $\begin{array}{c}7.47 \times 10^{-4} \\
\left(2.12 \times 10^{-5}\right)\end{array}$ & $\begin{array}{c}7.47 \times 10^{-4} \\
\left(2.12 \times 10^{-5}\right)\end{array}$ \\
\hline $\mathrm{K}$ & 0.27 & 0.27 & 0.27 & 0.27 \\
\hline LS & 0.72 & 0.72 & 0.72 & 0.72 \\
\hline $\mathrm{C}$ & 0.003 & 0.003 & 0.003 & 0.005 \\
\hline $\mathrm{P}$ & 1.00 & 1.00 & 1.00 & 1.00 \\
\hline $\begin{array}{c}\text { MUSLE Yield } \\
\text { tons/ac } \\
\text { (tonnes/ha) } \\
\end{array}$ & $\begin{array}{c}4.23 \times 10^{-6} \\
\left(9.48 \times 10^{-6}\right)\end{array}$ & $\begin{array}{c}4.23 \times 10^{-6} \\
\left(9.48 \times 10^{-6}\right)\end{array}$ & $\begin{array}{c}4.23 \times 10^{-6} \\
\left(9.48 \times 10^{-6}\right)\end{array}$ & $\begin{array}{c}4.23 \times 10^{-6} \\
\left(9.48 \times 10^{-6}\right)\end{array}$ \\
\hline
\end{tabular}

Predicted results were compared to actual sediment yield measured in the field. The MUSLE considerably under predicted actual sediment yield for the first storm event occurring in June. The storm event recorded in August did not result in any runoff being captured, therefore, the MUSLE over predicted sediment yield from a storm even of that magnitude (Table 14).

Table 14: MUSLE vs. actual storm sediment yield

\begin{tabular}{ccccc}
\hline Plot & $\begin{array}{c}\text { WVDOH Type B } \\
\text { (NTS, HP, 1) }\end{array}$ & $\begin{array}{c}\text { WVDOH Type B } \\
\text { (TS, HP, 1) }\end{array}$ & $\begin{array}{c}\text { WVDOH Type B } \\
\text { (NTS, S, 2) }\end{array}$ & $\begin{array}{c}\text { WVDOH Type B } \\
\text { (TS, S, 2) }\end{array}$ \\
\hline $\begin{array}{c}\text { MUSLE } \\
\text { Yield tons/ac } \\
\text { (tonnes/ha) }\end{array}$ & $\begin{array}{c}4.23 \times 10^{-6} \\
\left(9.48 \times 10^{-6}\right)\end{array}$ & $\begin{array}{c}4.23 \times 10^{-6} \\
\left(9.48 \times 10^{-6}\right)\end{array}$ & $\begin{array}{c}4.23 \times 10^{-6} \\
\left(9.48 \times 10^{-6}\right)\end{array}$ & $\begin{array}{c}4.23 \times 10^{-6} \\
\left(9.48 \times 10^{-6}\right)\end{array}$ \\
\hline $\begin{array}{c}\mathbf{6} / \mathbf{2 2} / \mathbf{1 7}- \\
\mathbf{6} / \mathbf{2 6} / \mathbf{1 7} \\
\text { tons/ac } \\
\text { (tonnes/ha) }\end{array}$ & $\mathrm{n} / \mathrm{a}$ & $\mathrm{n} / \mathrm{a}$ & $\mathrm{n} / \mathrm{a}$ & $7.92 \times 10^{-2}(0.178)$ \\
\hline $\begin{array}{c}\mathbf{8} / \mathbf{3 / 1 7 - 8 / 7 / 1 7} \\
\text { tons/ac } \\
\text { (tonnes/ha) }\end{array}$ & $\mathrm{n} / \mathrm{a}$ & $\mathrm{n} / \mathrm{a}$ & $\mathrm{n} / \mathrm{a}$ & $\mathrm{n} / \mathrm{a}$ \\
\hline
\end{tabular}

Note: $\mathrm{n} / \mathrm{a}$ is used where no runoff was captured from storm events or collection traps failed to collect any runoff

\subsection{Discussion}

Limitations of the study affected the overall results. Small test plots were the dominant restrictions; the MUSLE is ideally applied to entire watersheds or micro-watersheds (e.g. Sadeghi and Mizuyama 2007; Bhattarai and Dutta 2007; Arekhi 2008; Pandey et al. 2009; Zhang et al. 2009; Arekhi et al. 2012) Sadeghi et al. (2013) found that as plot size decreases, more 
corrections are needed to estimate actual watershed sediment yield and runoff. Assumptions were made that introduced error into the MUSLE sediment yield predictions. SCS Method, used to predict total runoff volume and peak runoff flowrate, also made assumptions that led to error in the results. For estimation purposes, a 1-year, 24-hour storm was assumed to predict total runoff volume and peak discharge, even though actual precipitation events recorded were not exactly 1-year, 24-hour storm events.

Because runoff discharge could not be measured over time during the storm event, hydrographs, such as those developed by Sadeghi and Mizuyama (2007) and Arekhi et al. (2012), could not be used in data analysis. Estimating peak runoff rate caused severe differences between estimated and observed sediment yield (Table 13). Small flow lengths resulted in short time of concentrations for each test plot because only sheet erosion was considered in calculations. Short flow lengths decrease the flow energy which, in turn, affectedly decreases the time of concentration (Sadeghi et al. 2013). Although Rational Method is recommended to be used to predict peak flowrate for smaller study areas, SCS Method was required so that accompanying total runoff volume could also be estimated (Hayes and Young 2006).

Lack of adequate equipment contributed to some losses of runoff and sediment during the collection process. Losses existed during data collection because the collection apparatuses were not lined underneath. Some runoff and sediment were escaping under the gutter. Also, total sediment was extrapolated from the total suspended solid density based on samples taken after storm events from each storage container. Therefore, sediment yield was estimated rather than measured.

Similar to calculations performed by Bhattarai and Dutta (2007), soil erodibility was based solely on the texture of the soil revealed from laboratory testing; this may have introduced inaccuracy in the $\mathrm{K}$ factor. The MUSLE does not account for soil saturation levels, therefore, it is known to under-predict sediment yield because runoff is increased when the soil is saturated (Pandey et al. 2009).

\subsection{Conclusion}

This study attempted to compare sediment and runoff erosion from four different seed bed preparation treatments resulting from natural storm events. Results were ultimately inconclusive, with respect to comparing sediment and runoff reduction by different seed bed preparation treatments, due to calculation errors and lack of adequate field data. However, the storm event recorded in August 2017 proved that ground cover resulting from each seed bed treatment was able to completely prevent runoff and sediment erosion from a storm event having at least 0.5 in $(1.27 \mathrm{~cm})$ of precipitation.

Future work should include a considerably larger study area (ex. watershed). If MUSLE is used to predict sediment yield from an area smaller than a watershed, a correction factor should be considered to account for the small area. More storm events should be recorded over a longer 
period than one growing season. Weather is unpredictable, so experimenting using natural rainfall events is difficult. Simulated rainfall would allow data to be taken immediately, eliminating some error. 


\subsection{Conclusions and Recommendations}

Vegetation cover is required by the NPDES permit to deter erosion from disturbed land resulting from highway construction. The permit requires $70 \%$ ground cover by vegetation on all disturbed ground after construction (Division of Water and Waste Management 2012). The objectives of this work were as follows:

1. Evaluate the long-term performance of experimental seed mixtures over multiple growing seasons

- Compare results of experimental native and introduced seed mixtures to current WVDOH seed mixtures

- Assess the performance of experimental high elevation seed mixtures

- Test the use of different seed bed preparation techniques on resulting vegetation

- Evaluate the success of using different soil amendments during planting

2. Calculate sediment and runoff produced from disturbed land with vegetation planted in different seed bed preparation techniques

Vegetation at field plots was monitored over the second and third growing seasons and sedimentation and runoff resulting from revegetated land in its third growing season was analyzed. Most long-term vegetation resulting from experimental mixtures was found to exceed or perform as well as the current WVDOH seed mixtures when tested at small-scale plots. High elevation mixtures did not result in adequate ground cover at a high elevation location (3294 ft $(1004 \mathrm{~m}))$, but showed success at lower elevations (846 ft $(258 \mathrm{~m})$ and $1837 \mathrm{ft}(560 \mathrm{~m})$ ). Therefore, the mixture was removed from consideration for WVDOH specifications because current WVDOH seed mixtures or other experimental seed mixtures produced satisfactory ground cover at a high elevation location.

Soil amendments, such as hydraulic growth mediums, were found to be comparable to topsoil in seed bed preparation with respect to vegetation establishment and persistence. Therefore, hydraulic growth mediums are highly recommended as a topsoil replacement when topsoil is too costly or difficult to obtain. Seed bed preparation (varying mulch type and planting in topsoil versus existing soil) was proven to be insignificant with respect to vegetation cover after the first growing season. In the future, seed bed preparation should be tested on varying slopes to determine if vegetation cover resulting from subplots mulched using straw mulch or hydraulic erosion control product is significantly different.

The MUSLE can be used as a model to predict soil erosion. When applied to this study, limitations of the experiment did not allow accurate sediment yield measurements to be estimated or measured in the field. However, resulting vegetation cover was proven to completely prevent runoff from small storm events. To accurately compare estimated and actual sediment yield from seed beds used in this study, the treatments should be tested at a large-scale location. 
It is recommended that plots should be monitored for more than two growing seasons to make accurate recommendations to WVDOH Specification "Section 652 Seeding and Mulching." Many biotic and abiotic factors affect establishing vegetation over time. Species diversity is constantly changing, and native vegetation has been proven to take multiple years to establish. 


\subsection{References}

Alpert, P., Bone, E., and Holzapfel, C. (2000). "Invasiveness, invisibility and the role of environmental stress in the spread of non-native plants." Perspectives in Plant Ecology, Evolution and Systematics, 3(1), 52-66.

Bakker, J. P., Olff, H., Willems, J. H., and Zobel, M. (1996). "Why do we need permanent plots in the study of long-term vegetation dynamics?" Journal of Vegetation Science, 7, 147156.

Bartholomew, P.W. and Williams, R.D. (2005) “Cool-Season Grass Development Response to Accumulated Temperature under a Range pf Temperature Regimes.” Crop Sci., 45, 529534.

Bartram, J. and Ballance, R. (1996). "Water Quality Monitoring - A Practical Guide to Design and Implementation of Freshwater Quality Studies and Monitoring Pragrammes.” United Nations Environment Programme and the World Health Organization.

Benik, S. R., Wilson, B.N., Biesboer, D.D., Hansen, B., and Stenlund, D. (2003). "Evaluation of erosion control products using natural rainfall events." Journal of Soil and Water Conservation, 58(2), 98-105.

Bhattarai, R. and Dutta, D. (2007). "Estimation of Soil Erosion and Sediment Yield Using GIS at Catchment Scale.” Water Resour Manage, 21, 1635-1647.

Blossey, B. (1999). "Before, during and after: the need for long-term monitoring in invasive plant species management.” Biological Invasions, 1, 301-311.

Blossey, B. and Nötzold, R. (1995). "Evolution of increased competitive ability in invasive nonindigenous plants: a hypothesis.” Journal of Ecology, 83, 887-889.

Bochet, E., Tormo, J., and García-Fayos, P. (2010). "Native Species for Roadslop Revegetation: Selection, Validation, and Cost Effectiveness.” Restoration Ecology, 18(5), 656-663.

Bonhomme, R. (2000). "Bases and limits to using 'degree.day' units.” European Journal of Agronomy, 13, 1-10.

Burke, M.J.W. and Grime, J.P. (1996). “An Experimental Study of Plant Community Invasibility.” Ecology, 77(3), 776-790.

Byers, J.E. (2002). "Impact of non-indigenous species on natives enhanced by anthropogenic alteration of selection regimes." Oikos, 97(3), 449-458. 
Center for Watershed Protection, Inc (CWP). (2012). "West Virginia Stormwater Management and Design Guidance Manual. West Virginia Department of Environmental Protection, Charelston, WV.

Clarke, P.J, Latz, P.K., and Albrecht, D.E. (2005). "Long-term changes in semi-arid vegetation: Invasion of an exotic perennial grass has larger effects than rainfall variability." Journal of Vegetation Science, 16(2), 237-248.

Cooper, K. (2011). "Evaluation of the Relationship Between the RUSLE R-Factor and Mean Annual Precipitation."

Daehler, C.C. (2003). "Performance Comparisons of Co-occuring Native and Alien Invasive Plants: Implications for Conservation and Restoration." Annu. Rev. Ecol. Syst., 34, 183211.

D'Antonio, C. and Meyerson, L. A. (2002). "Exotic Plant Species as Problems and Solutions in Ecological Restoration: A Synthesis.” Restoration Ecology, 10(4), 703-713.

Davies-Colley, R. J., and Smith, D. G. (2001). "Turbidity, Suspended Sediment, and Water Clarity: A Review." Journal of the American Water Resources Association, 37(5), 10851101.

Davis, E. M. (2015). "Evaluation of Roadside Vegetation for Erosion Control in West Virginia." thesis, presented to West Virginia University, WV, in partial fulfillment of the requirements for the degree of Master of Science.

Dietz, H. and Steinlein, T. (1996). "Determination of plant species cover by means of image analysis," Journal of Vegetation Science, 7, 131-136.

Doran, J.W., Elliott, E.T., and Paustian, K. (1998). "Soil microbial activity, nitrogen cycling, and long-term changes in organic carbon pools as related to fallow tillage management." Soil \& Tillage Research, 49, 3-18.

Dostál, P., Müllerová, J., Pyšek, P., Pergl, J., and Klinerová, T. (2013). "The impact of an invasive plant changes over time.” Ecology Letters, 16, 1277-1284.

Elzinga, C. L., Salzer, D. W., and Willoughby, J. W. (1998). "Measuring \& Monitoring Plant Populations." BLM Technical Reference 1730-1, Bureau of Land Management, Denver, Colo.

Espigares, T., las Heras, M. M., and Nicolau, J. M. (2011). "Performance of Vegetation in Reclaimed Slopes Affected by Soil Erosion.” Restoration Ecology, 19(1), 35-44. 
Faucette, L. B., Jordan, C. F., Risse, L. M., Cabrera, M., Coleman, D. C., and West, L. T. (2005). "Evaluation of stormwater from compost and conventional erosion control practices in activities" Journal of Soil and Water Conservation, 60(6), 288-297.

Faucette, L. B., Risse, L. M., Jordan, C. F., Cabrera, M. L., Coleman, D. C., and West, L. T. (2006). "Vegetation and soil quality effects from hydroseed and compost blankets used for erosion control in construction activities." Journal of Soil and Water Conservation, 61(6), 355-362.

Frank, A.B. (1996). "Evaluating Grass Development for Grazing Management.” Rangelands, 18(3), 106-109.

Frank, A.B., and Hofmann, L. (1989). "Relationship among Grazing Management, Growing Degree-Days, and Morphological Development for Native Grasses on the Northern Great Plains." Journal of Range Management, 42(3), 199-202.

Franks, C. D., Goings, K. A. (1997) “Above-Ground Biomass (Plant) Determinations.” National Soil Survey Center, Natural Resources Conservation Service, United States Department of Agriculture, Lincoln, NE.

Fukami, T. and Wardle, D.A. (2005). "Long-term ecological dynamics: reciprocal insights from natural and anthropogenic gradients." Proc. R. Soc. B., 272, 2105-2115.

Gruber, N. and Galloway, J. N. (2008). "An Earth-system perspective of the global nitrogen cycle." Nature, 451(17), 293-296.

Hancock, D. and Andrae, J.G. (2016). "White Clover Establishment and Management." UGA Extension, <http://extension.uga.edu/publications/detail.html?number=B1251> (Aug. 15, 2017).

Handel, S.N., Robinson, G.R., and Beattie A.J. (1994). "Biodiversity Resources for Restoration Ecology.” Restoration Ecology, 2(4), 230-241.

Hayes, D.C and Young, R.L. (2006). "Comparison of Peak Discharge and Runoff Characterisitic Estimates from the Rational Method to Field Observations for Small Basins in Central Virginia." U.S. Department of Interior, U.S. Geological Survey, Reston, VA.

Hilvers, G. A. (2015). "Development of an Erosion Control Seed Mixture that Includes Native Species." thesis, presented to West Virginia University, WV, in partial fulfillment of the requirements for the degree of Master of Science.

Hilvers, G.A., Hopkinson, L., and Davis, E. (2017). "Evaluation of Revegetation Techniques for Roadside Construction Sites." Journal of Environment Engineering and Landscape Management, 25(3), 305-315. 
Holl, K. D. (2002). "Long-term vegetation recovery on reclaimed coal surface mines in the eastern USA.” Journal of Applied Ecology, 39, 960-970.

Hopkinson, L., Davis, E., and Hilvers, G. (2015). Evaluation and Recommendation to the WVDOH's Seeding and Mulching Processes and Specifications, West Virginia University, Morgantown, WV.

Kaufman, M. M. (2000). "Erosion Control at Construction Sites: The Science-Policy Gap." Environmental Management, 26(1), 89-97.

Kelley, H. W. (1990). Keeping the Land Alive: Soil Erosion-its Causes and Cures, Issue 50, Food and Agriculture Organization of the United Nations, Rome, Italy.

Kelsey, K. (2002). "USE OF THE REVISED UNIVERSAL SOIL LOSS EQUATION ON AN EVENT-BY-EVENT BASIS," thesis, presented to the University of Wisconson-Stevens Point, WI, in partial fulfillment of the requirements for the degree of Master of Science.

Lesica, P. and Allendorf, F. W. (1999). "Ecological Genetics and the Restoration of Plant Communities: Mix or Match?” Restoration Ecology, 7(1), 42-50.

Li, X., Lau, S., Kayhanian, M., and Stenstrom, M.K. (2005). "Particle Size Distribution in Highway Runoff.” Journal of Environmental Engineering, 131(9), 1267-1276.

Liu, Y., Hu, J., Wang, T., Cai, C., Li, Z., and Zhang, Y. (2016). "Effects of vegetation cover and road-concentrated flow on hillslope erosion in rainfall and scouring simulation tests in the Three Gorges Reservoir Area, China." Catena, 136, 108-117.

Martínez-Zavala, L., López, A. J., and Bellinfante, N. (2008). "Seasonal variability of runoff and soil loss on forest road backslopes under simulated rainfall.” Catena, 74, 73-79.

McCool, L.C., Foster, G.R., Mutchler, C.K., and Meyer, L.D. (1989). "Revised Slope Length Factor for the Universal Soil Loss Equation." Transactions of the ASAE, 32(5), 15711576.

Miller, P., Lanier, W., and Brandt, S. (2001) "Using Growing Degree Days to Predict Plant Stages." MSU Extension Services.

Montalvo, A. M., McMillan, P. A., and Allen, E. B. (2002). "The Relative Importance of Seeding Method, Soil Ripping, and Soil Variables on Seeding Success." Restoration Ecology, 10(1), 52-67.

Muckel, G. B. (2004). “Understanding Soil Risks and Hazards. Using Soil Survey to Identify Areas With Risks and Hazards to Human Life and Property." National Soil Survey Center, Natural Resources Conservation Service, United States Department of Agriculture, Lincoln, NE. 
Natural Resources Conservation Service (NRCS). (2010). "Chapter 15: Time of Concentration." Part 630 Hydrology National Engineering Handbook, United States Department of Agriculture, Washington, D.C.

Natural Resources Conservation Service. (2006). "Model Simulation of Soil Loss, Nutrient Loss, and Change in Soil Organic Carbon Associated with Crop Production." United States Department of Agriculture, Washington, D.C.

Natural Resources Conservation Service. (2008). "Soil Quality Indicators." United States Department of Agriculture, Washington, D.C.

Natural Resources Conservation Service. (2016) “Web Soil Survey.” United States Department of Agriculture, Washington, D.C.

Nearing, M.A., Jetten, V., Vaffaut, C., Cerdan, O., Couturier, A., Hernandez, M., Le Bissonnais, Y., Nichols, M.H., Nunes, J.P., Renschler, C.S., Souchère, V., and van Ooost, K. (2005). "Modeling response of soil erosion and runoff to changes in precipitation and cover." Catena, 61, 131-154.

Newman, G. J. and Redente, E. F. (2001). "Long-term plant community development as influenced by revegetation techniques." Journal of Range Management, 54(6), 717-724.

North Carolina State University. (2107) "Module 1: Rainfall-Runoff." Erosion \& Sediment Control/Stormwater Certification, <https://www.bae.ncsu.edu/bae/workshops/dot/pdf/mod1_text3b.pdf > (Jun. 1, 2017).

Pandey, A., Chowdary, V.M., and Mal, B.C. (2009). "Sediment yield modelling of an agricultural watershed using MUSLE, remote sensing and GIS." Paddy Water Environ, 7, 105-113.

Precipitation Frequency Data Server (PFDS). (2017). Hydrometeorological Design Studies Center, NOAA's National Weather Service, <http://hdsc.nws.noaa.gov/hdsc/pfds/pfds_map_cont.html?bkmrk=wv> (May 30, 2017)

Qiao, C., Liu, L., Hu, S., Compton, J. E., Greaver, T. L., and Li, Q. (2015). "How inhibiting nitrification affects nitrogen cycle and reduces environmental impacts of anthropogenic nitrogen input." Global Change Biology, 21, 1249-1257.

Renard, K. G., Foster, G. R., Weesies, G. A., McCool, D. K., and Yoder, D. C. (1997). "Predicting Soil Erosion by Water: A Guide to Conservation Planning With the Revised Universal Soil Loss Equation (RUSLE)." Agriculture Handbook No. 703, Agricultural Research Service, United States Department of Agriculture, Washington, D.C. 
Renard, K. G., Foster, G. R., Yoder, D. C., and McCool, D. K. (1994a). "RUSLE revisited: Status, questions, answers, and the future." Journal of Soil and Water Conservation, 49(3), 213-220.

Renard, K. G., Laflen, J. M., Foster, G. R., and McCool, D. K. (1994b). The Revised Universal Soil Loss Equation Methods, $2^{\text {nd }}$ Ed., Soil and Water Cons. Soc., Iowa.

Rentch, J.S., Fortney, R.H., Stephenson, S.L., Adams, H.S., Grafton, W.N., and Anderson, J.T. (2005). "Vegetation-Site Relationships of Roadside Plant Communities in West Virginia, USA." Journal of Applied Ecology, 42(1), 129-138.

Rickson, R.J. (2006). "Controlling sediment at source: an evaluation of erosion control geotextiles.” Earth Surf. Process. Landforms, 31, 550-560.

Sadeghi, S.H.R. and Mizuyama, T. (2007). "Applicability of the Modified Universal Soil Loss Equation for prediction of sediment yield in Khanmirza watershed, Iran." Hydrological Sciences Journal, 52(5), 1068-1075.

Sadeghi, S. H. R., Seghaleh, M. B., and Rangavar, A. S. (2013). "Plot sizes dependency of runoff and sediment yield estimates from a small watershed." Catena, 102, 55-61.

SAS Institute Inc. (2016). Using $J M P^{\circledR} 13$, SAS Institute Inc., Cary, NC.

Schwab, G. O., Frevert, R. K., Edminster, T. W. and Barner, K. K. (1981). Soil and water conservation engineering, $3^{\text {rd }} \mathrm{Ed}$, John Wiley \& Sons, New York.

Seabloom, E.W., Harpole, W.S., Reichman, O.J., and Tilman, D. (2003). "Invasion, competitive dominance, and resource use by exotic and native California grassland species." PNAS, 100(23), 13384-13389.

Shen, H.W. and Julien, P.Y. (1993). "Erosion and Sediment Transport." Handbook of Hydrology, $1^{\text {st }}$ ed., (12), McGraw-Hill, Inc., New York, NY.

Sidhu, R. S., Dougherty, M., Zech, W. C., and Guertal, B. (2015) "Cost Effectiveness of Erosion Control Covers during Vegetation Establishment under Simulated Rainfall.” Journal of Water Resource and Protection, 7, 119-129.

Sills, J. (2014). "Algal blooms: Noteworthy nitrogen.” American Association for the Advancement of Science, 346(6206), 175-176.

Skousen, J.G. and Venable, C.L. (2008). "Establishing Native Plants on Newly-Constructed and Older-Reclaimed Sites along West Virginia Highways." Land Degrad. Develop., 19, 388396. 
Soil Conservaton Service. (1957). "Use of Storm and Watershed Characteristics in Sythetic Hydrograph Analysis and Application." U.S. Department of Agriculture, Washington, D.C.

Soil Conservation Service. (1964) "SCS National Engineering Handbook." U.S. Department of Agriculture, Washington, D.C.

Soil Conservation Service. (1987). "Soil Mechanics Level I. Module 3-USDA Textural Soil Classification. Study Guide.” United States Department of Agriculture, Washington, D.C.

Soil Quality Institute. (2000). "Soil Quality-Urban Technical Note No. 1. Erosion and Sedimentation on Construction Sites." X-177 Urban Technical Note No. 1, Natural Resources Conservation Service, United States Department of Agriculture (USDA), Auburn, AL.

Tikka, P.M., Koski, P.S., Kivelä, R.A., and Kuitunen, M.T. (2000) "Can grassland plant communities be preserved on road and railway verges?" Applied Vegetation Science, 3, 25-32.

Thompson, K., Hodgson, J.G., Grime, P., and Burke, M.J. (2001). "Plant traits and temporal scale: evidence from a 5-year invasion experiment using native species." Journal of Ecology, 89, 1054-1060.

Toy, T. J., Foster, G. R., Renard, K. G. (2002). Soil Erosion: Processes, Prediction, Measurement, and Control, John Wiley \& Sons, Inc., New York, N.Y.

Trenouth, W.R. and Gharabaghi, B. (2015). "Event-based soil loss models for construction sites.” Journal of Hydrology, 524, 780-788.

United States Department of Agriculture (USDA). (2004). "National Research Project for Simulated Rainfall-Surface Runoff Studies."

Division of Water and Waste Management. (2012). National Pollutant Discharge Elimination Sustem Water Pollution Control Permit (Permit No. WV0115924), West Virginia Department of Environmental Protection (WVDEP), Charleston, WV.

West Virginia Division of Highways. (2010a). "Administrative Operating Procedures: Highway Operations: Core Maintenance Plans.” Section V, Chapter 15, Charleston, WV.

West Virginia Division of Highways. (2010b). "Section 652-Seeding and Mulching. Standard Specifications Roads and Bridges." Charleston, WV.

West Virginia Division of Natural Resources. (2009). "Invasive Species of West Virginia." Elkins, WV. 
Williams, J.R. (1975). "Sediment-yield prediction with universal equation using runoff energy factor. Present and Prospective Technology for Predicting Sediment Yield and Sources, 40, 244-252.

Williams, J.R. and Berndt, H.D. (1977). "Sediment yield prediction based on watershed hydrology. Trans. Am. Soc. Agric. Eng., 20(6), 1100-1104.

Wischmeier, W. H. and Smith, D. D. (1978). "Predicting Rainfall Erosion Losses-A Guide to Conservation Planning." Agriculture Handbook No. 537, Science and Education Administration, United States Department of Agriculture, Washington, D.C.

Yang, Y., Yang, J., Zhao, T., Huang, X., and Zhao, P. (2016). "Ecological restoration of highway slope by covering with straw-mat and seeding with grass-legume mixture." Ecological Engineering, 90, 68-76. 


\subsection{Appendix}

\subsection{CH-1A Vegetation Data}

Table 15: CH-1A ground cover data (2016)

\begin{tabular}{cccccc}
\hline & $\mathbf{6 / 2 2 / 2 0 1 6}$ & $\mathbf{7 / 2 7 / 2 0 1 6}$ & $\mathbf{8 / 2 5 / 2 0 1 6}$ & $\mathbf{9 / 2 7 / 2 0 1 6}$ & $\mathbf{1 0 / 2 7 / 2 0 1 6}$ \\
\hline DOH Medians & 100.0 & 93.3 & 99.7 & 99.0 & 97.7 \\
\hline DOH Cut/Fill & 100.0 & 97.3 & 100.0 & 99.3 & 99.0 \\
\hline Mowable Areas & 100.0 & 97.0 & 99.7 & 93.7 & 93.7 \\
\hline Warm Season & 100.0 & 91.3 & 99.7 & 94.3 & 94.3 \\
\hline Cool Season & 100.0 & 98.0 & 98.3 & 90.0 & 91.0 \\
\hline High Elevation & 100.0 & 90.0 & 99.7 & 91.0 & 93.3 \\
\hline
\end{tabular}

Table 16: CH-1A ground cover by species (2016)

\begin{tabular}{cccc}
\hline & Planted & Not Planted & No Cover \\
\hline DOH Medians & 89 & 8 & 2 \\
\hline DOH Cut/Fill & 91 & 8 & 1 \\
\hline Mowable Areas & 78 & 16 & 7 \\
\hline Warm Season & 54 & 41 & 5 \\
\hline Cool Season & 81 & 10 & 9 \\
\hline High Elevation & 61 & 33 & 7 \\
\hline
\end{tabular}

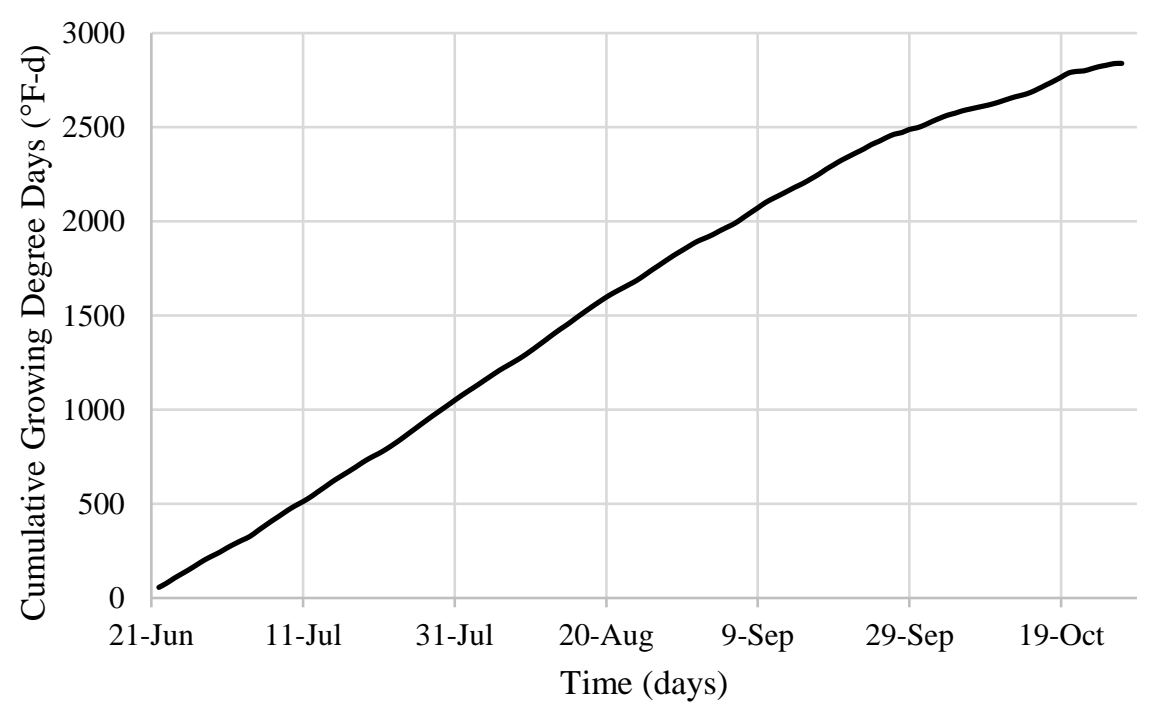

Figure 74: CH-1 cumulative degree days (2016) 


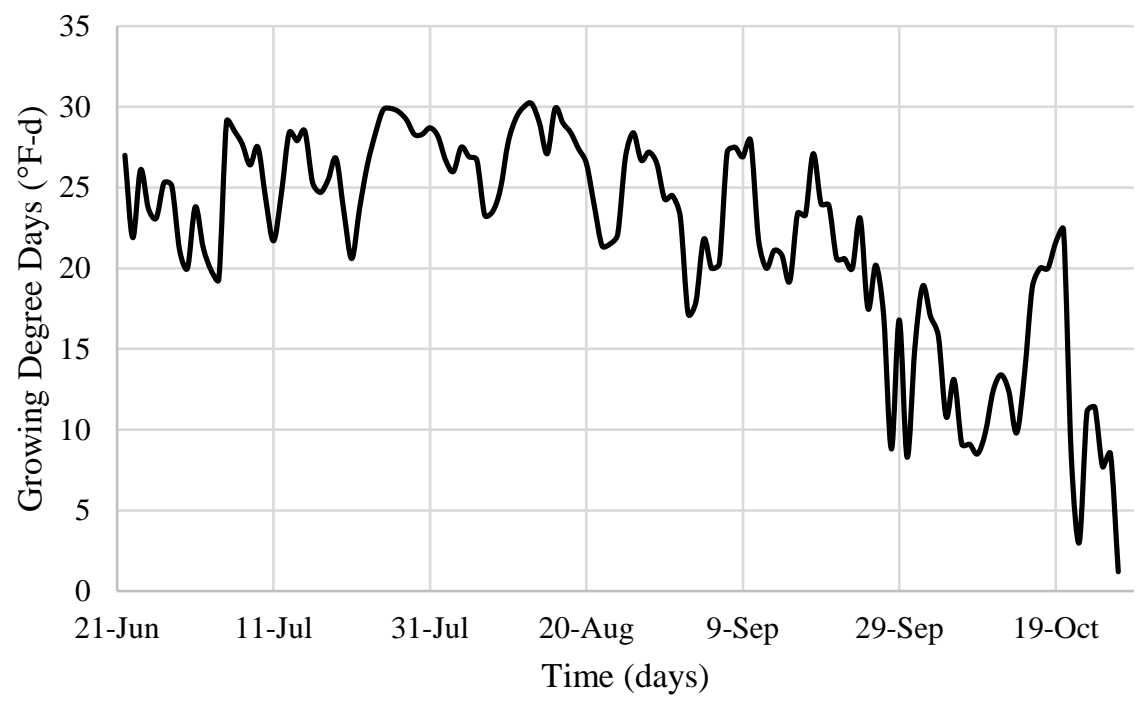

Figure 75: CH-1 daily growing degree days (2016)

Table 17: CH-1A ground cover data (2017)

\begin{tabular}{cccc}
\hline & $\mathbf{6 / 6 / 2 0 1 7}$ & $\mathbf{7 / 1 0 / 2 0 1 7}$ & $\mathbf{8 / 1 / 2 0 1 7}$ \\
\hline DOH Medians & 98.7 & 97.0 & 97.6 \\
\hline DOH Cut/Fill & 98.0 & 99.0 & 98.3 \\
\hline Mowable Areas & 97.7 & 99.3 & 91.5 \\
\hline Warm Season & 95.7 & 98.3 & 92.4 \\
\hline Cool Season & 98.3 & 98.0 & 97.9 \\
\hline High Elevation & 98.0 & 96.0 & 90.7 \\
\hline
\end{tabular}

Table 18: CH-1A ground cover by species (2017)

\begin{tabular}{cccc}
\hline & Planted & Not Planted & No Cover \\
\hline DOH Medians & 75 & 20 & 4 \\
\hline DOH Cut/Fill & 90 & 5 & 2 \\
\hline Mowable Areas & 37 & 49 & 8 \\
\hline Warm Season & 48 & 37 & 7 \\
\hline Cool Season & 92 & 1 & 2 \\
\hline High Elevation & 22 & 66 & 9 \\
\hline
\end{tabular}




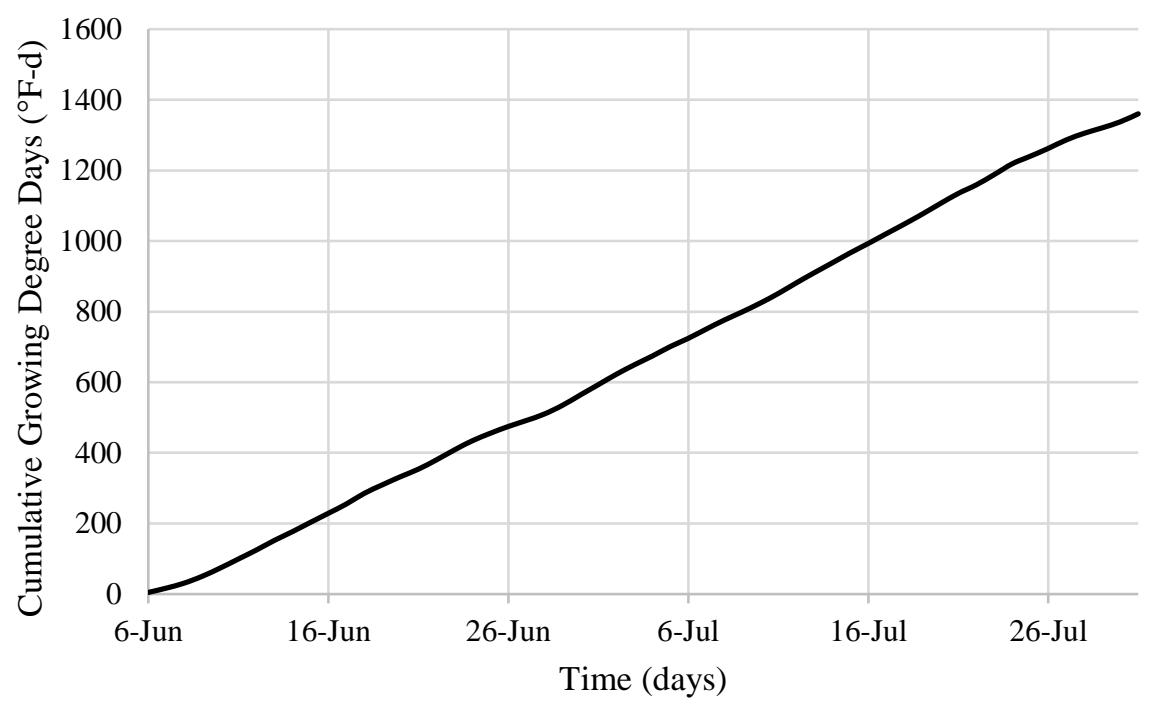

Figure 76: $\mathrm{CH}-1$ cumulative degree days (2017)

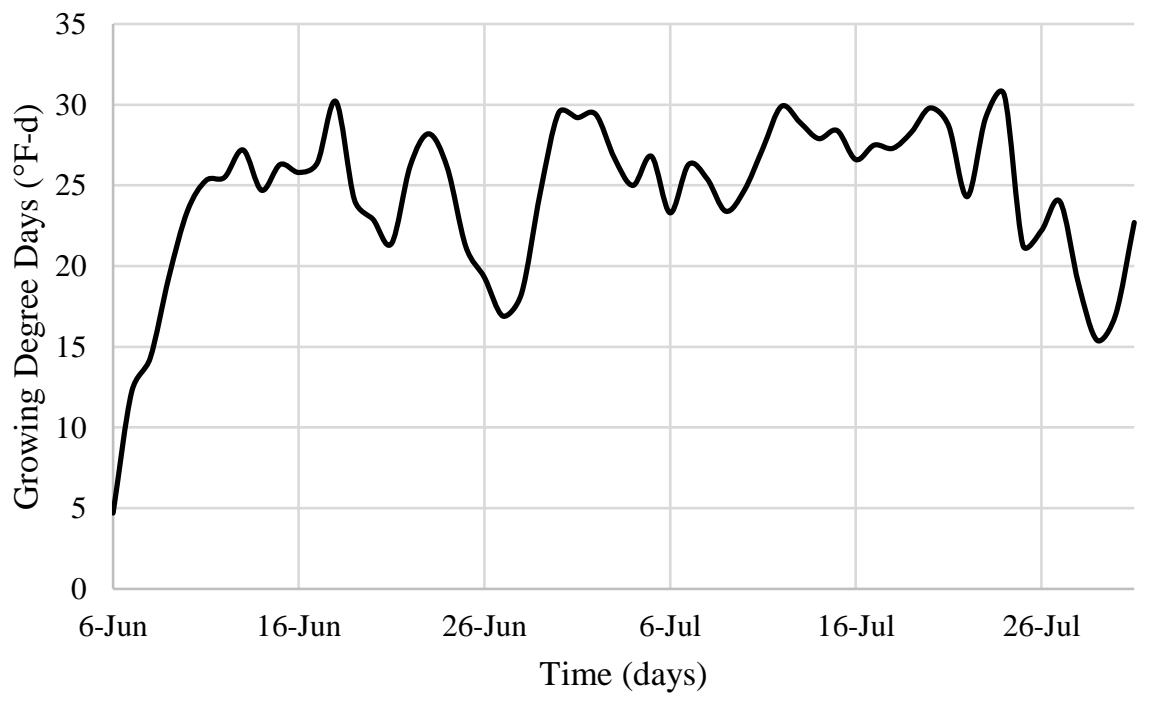

Figure 77: CH-1 daily growing degree days (2017) 


\subsection{CH-1A Soil Data}

Table 19: CH-1A soil compaction data

\begin{tabular}{|c|c|c|c|c|}
\hline & & \multicolumn{3}{|c|}{ Depth (in) } \\
\hline Date & Seed Mixture & 3 & 6 & 9 \\
\hline \multirow{6}{*}{$6 / 22 / 2016$} & DOH Medians & 1.2 & 0.5 & 0.3 \\
\hline & DOH Cut/Fill & 2.1 & 1 & $\mathrm{n} / \mathrm{a}$ \\
\hline & Mowable Areas & 1.7 & 1.1 & 0.3 \\
\hline & Warm Season & 2.4 & 1.4 & $\mathrm{n} / \mathrm{a}$ \\
\hline & Cool Season & 1.4 & $\mathrm{n} / \mathrm{a}$ & $\mathrm{n} / \mathrm{a}$ \\
\hline & High Elevation & 1.5 & 0.3 & $\mathrm{n} / \mathrm{a}$ \\
\hline \multirow{6}{*}{$10 / 27 / 2016$} & DOH Medians & 1.1 & $\mathrm{n} / \mathrm{a}$ & $\mathrm{n} / \mathrm{a}$ \\
\hline & DOH Cut/Fill & 1.2 & 0.6 & $\mathrm{n} / \mathrm{a}$ \\
\hline & Mowable Areas & 1.5 & 0.5 & $\mathrm{n} / \mathrm{a}$ \\
\hline & Warm Season & 1.5 & $\mathrm{n} / \mathrm{a}$ & $\mathrm{n} / \mathrm{a}$ \\
\hline & Cool Season & 1.8 & $\mathrm{n} / \mathrm{a}$ & $\mathrm{n} / \mathrm{a}$ \\
\hline & High Elevation & 1.9 & 0.4 & $\mathrm{n} / \mathrm{a}$ \\
\hline \multirow{6}{*}{ 6/6/2017 } & DOH Medians & 1.2 & 0.4 & 0.3 \\
\hline & DOH Cut/Fill & 2.0 & 1.3 & 0.4 \\
\hline & Mowable Areas & 1.8 & 0.9 & 0.4 \\
\hline & Warm Season & 1.4 & 1.2 & $\mathrm{n} / \mathrm{a}$ \\
\hline & Cool Season & 1.6 & 0.6 & $\mathrm{n} / \mathrm{a}$ \\
\hline & High Elevation & 1.8 & 0.5 & $\mathrm{n} / \mathrm{a}$ \\
\hline
\end{tabular}

Note: $\mathrm{n} / \mathrm{a}$ is used where depths could not be reached by penetrometer due to high compaction

\subsection{CH-2 Vegetation Data}

Table 20: $\mathrm{CH}-2$ ground cover data (2016)

\begin{tabular}{cccccc}
\hline & $\mathbf{6 / 2 2 / 2 0 1 6}$ & $\mathbf{7 / 2 7 / 2 0 1 6}$ & $\mathbf{8 / 2 5 / 2 0 1 6}$ & $\mathbf{9 / 2 7 / 2 0 1 6}$ & $\mathbf{1 0 / 2 7 / 2 0 1 6}$ \\
\hline DOH Medians & 90.7 & 83.7 & 88.0 & 83.0 & 86.3 \\
\hline Mowable Areas & 75.7 & 73.0 & 86.3 & 80.0 & 87.3 \\
\hline Warm Season & 62.3 & 60.7 & 80.7 & 65.3 & 76.7 \\
\hline Cool Season & 82.3 & 70.7 & 89.7 & 84.3 & 90.0 \\
\hline High Elevation & 64.0 & 40.7 & 74.0 & 68.3 & 75.3 \\
\hline
\end{tabular}

Table 21: CH-2 ground cover by species (2016)

\begin{tabular}{cccc}
\hline & Planted & Not Planted & No Cover \\
\hline DOH Medians & 83 & 3 & 14 \\
\hline Mowable Areas & 85 & 3 & 13 \\
\hline Warm Season & 45 & 32 & 23 \\
\hline Cool Season & 87 & 3 & 10 \\
\hline High Elevation & 24 & 51 & 25 \\
\hline
\end{tabular}




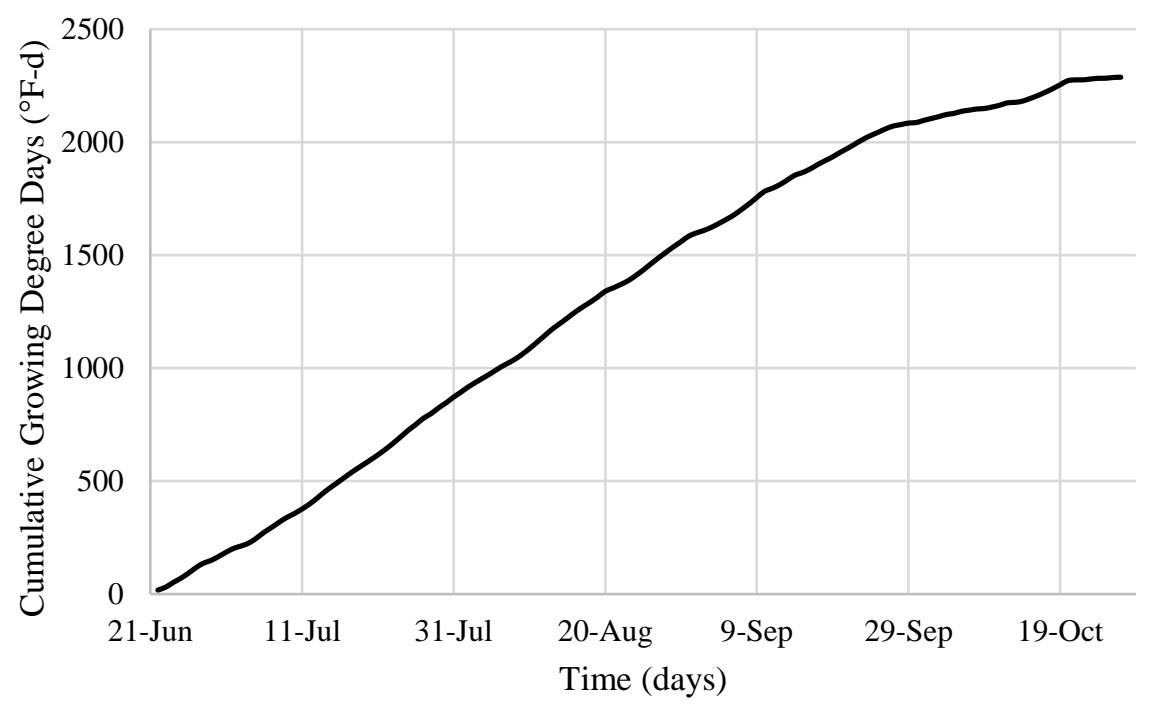

Figure 78: $\mathrm{CH}-2$ cumulative growing degree days (2016)

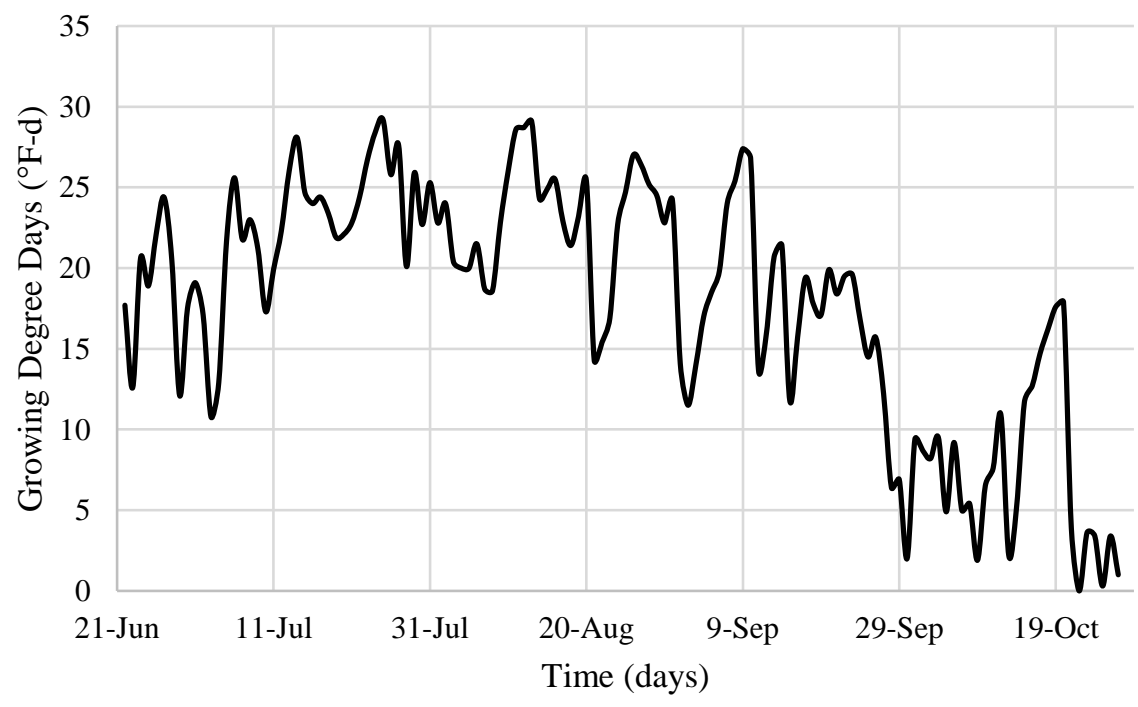

Figure 79: $\mathrm{CH}-2$ daily growing degree days (2016)

Table 22: CH-2 ground cover data (2017)

\begin{tabular}{cccc}
\hline & $\mathbf{6 / 6 / 2 0 1 7}$ & $\mathbf{7 / 1 0 / 2 0 1 7}$ & $\mathbf{8 / 1 / 2 0 1 7}$ \\
\hline DOH Medians & 95.0 & 91.7 & 98.3 \\
\hline Mowable Areas & 88.0 & 84.0 & 94.0 \\
\hline Warm Season & 84.0 & 71.0 & 87.0 \\
\hline Cool Season & 89.7 & 84.3 & 94.4 \\
\hline High Elevation & 73.3 & 69.0 & 84.0 \\
\hline
\end{tabular}


Table 23: CH-2 ground cover by species (2017)

\begin{tabular}{cccc}
\hline & Planted & Not Planted & No Cover \\
\hline DOH Medians & 88 & 6 & 2 \\
\hline Mowable Areas & 83 & 6 & 6 \\
\hline Warm Season & 56 & 28 & 13 \\
\hline Cool Season & 74 & 15 & 5 \\
\hline High Elevation & 46 & 33 & 15 \\
\hline
\end{tabular}

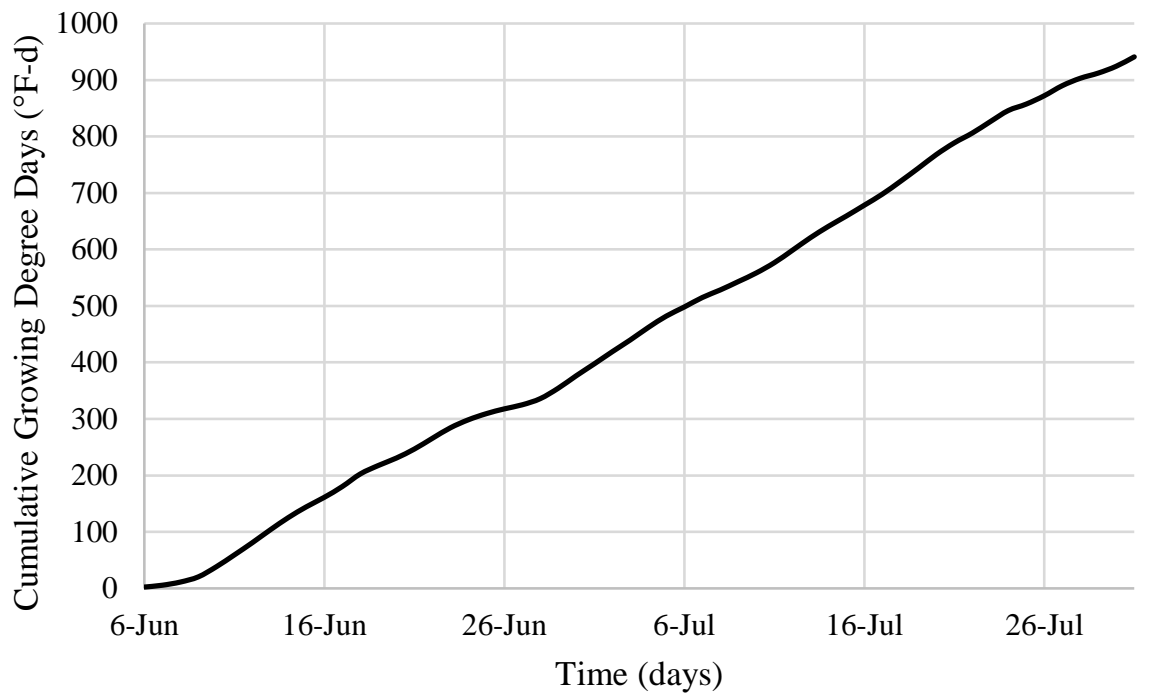

Figure 80: $\mathrm{CH}-2$ cumulative growing degree days (2017)

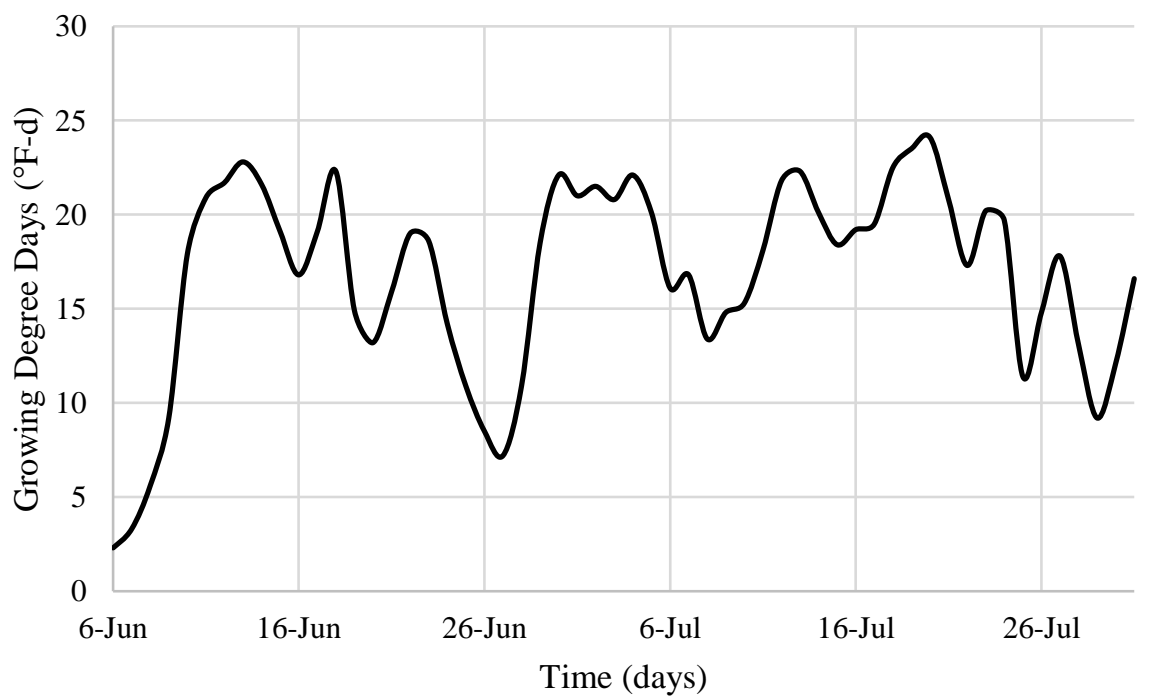

Figure 81: $\mathrm{CH}-3$ daily growing degree days (2017) 
Table 24: CH-2 soil compaction data

\begin{tabular}{ccccc}
\hline & & \multicolumn{3}{c}{ Depth (in) } \\
\hline \multirow{4}{*}{ Date } & Seed Mixture & $\mathbf{3}$ & $\mathbf{6}$ & $\mathbf{9}$ \\
\hline \multirow{3}{*}{$\mathbf{6 2 2 / 2 0 1 6}$} & DOH Medians & 2.2 & 0.7 & $\mathrm{n} / \mathrm{a}$ \\
\cline { 2 - 5 } & Mowable Areas & 1.8 & 0.3 & $\mathrm{n} / \mathrm{a}$ \\
\cline { 2 - 5 } & Warm Season & 1.2 & 0.3 & $\mathrm{n} / \mathrm{a}$ \\
\cline { 2 - 5 } & Cool Season & 1.4 & $\mathrm{n} / \mathrm{a}$ & $\mathrm{n} / \mathrm{a}$ \\
\cline { 2 - 5 } $\mathbf{1 0 / 2 7 / 2 0 1 6}$ & High Elevation & 1.4 & $\mathrm{n} / \mathrm{a}$ & $\mathrm{n} / \mathrm{a}$ \\
\hline & DOH Medians & 1.2 & 0.5 & $\mathrm{n} / \mathrm{a}$ \\
\cline { 2 - 5 } & Mowable Areas & 1.1 & $\mathrm{n} / \mathrm{a}$ & $\mathrm{n} / \mathrm{a}$ \\
\cline { 2 - 5 } & Warm Season & 1.0 & $\mathrm{n} / \mathrm{a}$ & $\mathrm{n} / \mathrm{a}$ \\
\cline { 2 - 5 } & Cool Season & 0.4 & 0.3 & $\mathrm{n} / \mathrm{a}$ \\
\hline & High Elevation & 1.8 & $\mathrm{n} / \mathrm{a}$ & $\mathrm{n} / \mathrm{a}$ \\
\hline \multirow{3}{*}{$\mathbf{6 / 6 / 2 0 1 7}$} & DOH Medians & 0.6 & $\mathrm{n} / \mathrm{a}$ & $\mathrm{n} / \mathrm{a}$ \\
\cline { 2 - 5 } & Mowable Areas & 0.5 & $\mathrm{n} / \mathrm{a}$ & $\mathrm{n} / \mathrm{a}$ \\
\cline { 2 - 5 } & Warm Season & 0.9 & 0.3 & $\mathrm{n} / \mathrm{a}$ \\
\cline { 2 - 5 } & Cool Season & 0.7 & 0.3 & $\mathrm{n} / \mathrm{a}$ \\
\cline { 2 - 5 } & High Elevation & 0.5 & $\mathrm{n} / \mathrm{a}$ & $\mathrm{n} / \mathrm{a}$ \\
\hline
\end{tabular}

Note: $\mathrm{n} / \mathrm{a}$ is used where depths could not be reached by penetrometer due to high compaction

\subsection{CH-3 Vegetation Data}

Table 25: CH-3 ground cover data (2016)

\begin{tabular}{cccccc}
\hline & $\mathbf{6 / 2 2 / 2 0 1 6}$ & $\mathbf{7 / 2 7 / 2 0 1 6}$ & $\mathbf{8 / 2 5 / 2 0 1 6}$ & $\mathbf{9 / 2 7 / 2 0 1 6}$ & $\mathbf{1 0 / 2 7 / 2 0 1 6}$ \\
\hline DOH Medians (TS, HP) & 90.5 & 93.5 & 97.0 & 87.5 & 92.5 \\
\hline DOH Medians (NTS, HP) & 98.0 & 99.5 & 100.0 & 99.0 & 99.0 \\
\hline DOH Medians (TS,S) & 93.0 & 91.5 & 98.0 & 93.0 & 95.5 \\
\hline DOH Medians (NTS,S) & 95.5 & 95.0 & 97.5 & 92.5 & 97.0 \\
\hline Warm Season (TS, HP) & 83.5 & 92.5 & 96.0 & 93.0 & 91.5 \\
\hline Warm Season (NTS, HP) & 92.5 & 85.0 & 95.5 & 93.0 & 90.0 \\
\hline Warm Season (TS,S) & 76.0 & 85.0 & 93.5 & 93.5 & 90.0 \\
\hline Warm Season (NTS,S) & 91.5 & 86.5 & 95.5 & 91.5 & 93.0 \\
\hline Cool Season (TS, HP) & 98.5 & 98.0 & 98.0 & 91.5 & 95.5 \\
\hline Cool Season (NTS, HP) & 100.0 & 88.5 & 91.5 & 84.0 & 90.5 \\
\hline Cool Season (TS,S) & 100.0 & 95.5 & 98.0 & 92.5 & 96.0 \\
\hline Cool Season (NTS,S) & 100.0 & 94.5 & 99.5 & 96.0 & 95.5 \\
\hline
\end{tabular}


Table 26: CH-3 ground cover by species (2016)

\begin{tabular}{cccc}
\hline & Planted & Not Planted & No Cover \\
\hline DOH Medians (TS, HP) & 58 & 35 & 8 \\
\hline DOH Medians (TS, S) & 58 & 38 & 5 \\
\hline DOH Medians (NTS, HP) & 97 & 2 & 1 \\
\hline DOH Medians (NTS, S) & 87 & 11 & 3 \\
\hline Warm Season (TS, HP) & 76 & 16 & 9 \\
\hline Warm Season (TS, S) & 72 & 19 & 10 \\
\hline Warm Season (NTS, HP) & 84 & 7 & 10 \\
\hline Warm Season (NTS, S) & 74 & 20 & 7 \\
\hline Cool Season (TS, HP) & 93 & 3 & 5 \\
\hline Cool Season (TS, S) & 93 & 4 & 4 \\
\hline Cool Season (NTS, HP) & 90 & 1 & 5 \\
\hline Cool Season (NTS, S) & 96 & 0 & 10 \\
\hline
\end{tabular}

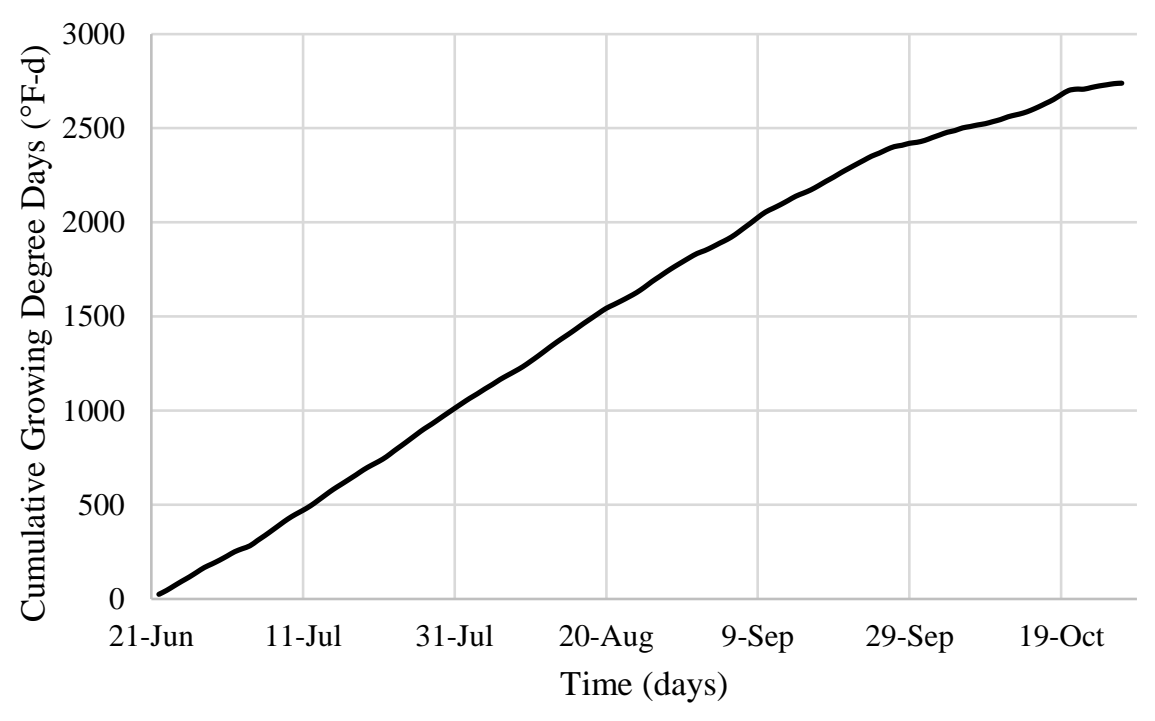

Figure 82: CH-3 cumulative growing degree days (2016) 


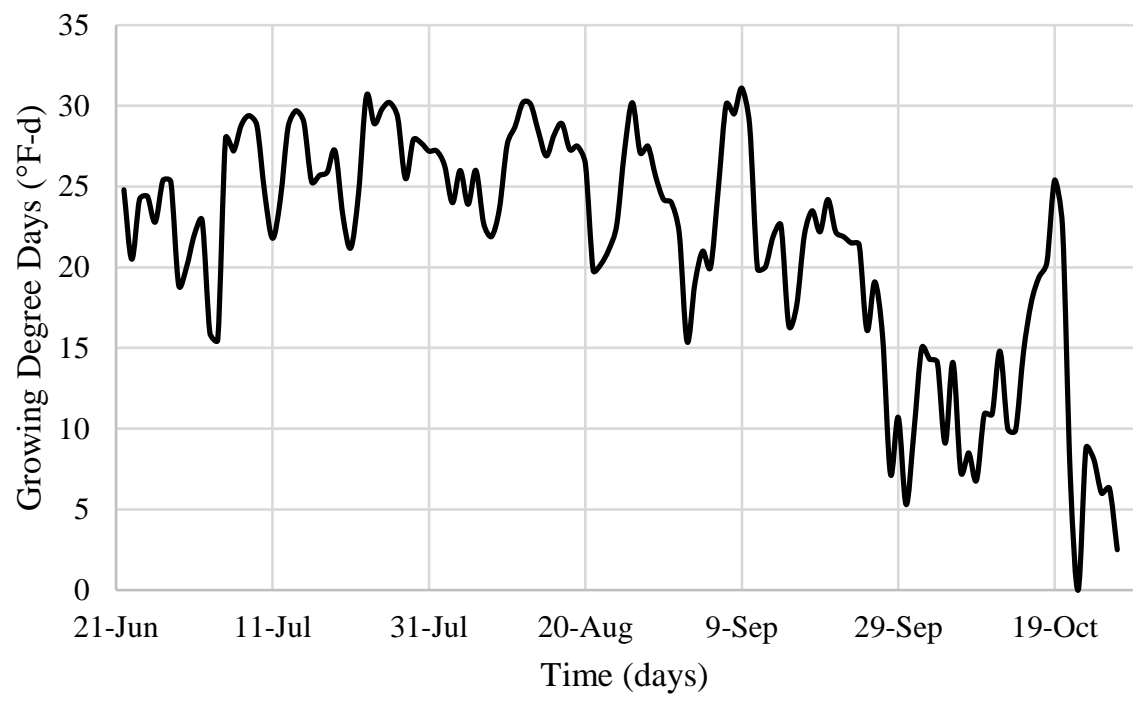

Figure 83: $\mathrm{CH}-3$ daily growing degree days (2016)

Table 27: CH-3 ground cover data (2017)

\begin{tabular}{cccc}
\hline & $\mathbf{6 / 6 / 2 0 1 7}$ & $\mathbf{7 / 1 0 / 2 0 1 7}$ & $\mathbf{8 / 1 / 2 0 1 7}$ \\
\hline DOH Medians (TS, HP) & 98.0 & 93.0 & 96.4 \\
\hline DOH Medians (NTS, HP) & 100.0 & 94.5 & 99.5 \\
\hline DOH Medians (TS,S) & 92.0 & 94.5 & 98.4 \\
\hline DOH Medians (NTS,S) & 97.5 & 93.0 & 99.5 \\
\hline Warm Season (TS, HP) & 94.5 & 82.0 & 89.2 \\
\hline Warm Season (NTS, HP) & 97.0 & 90.5 & 93.4 \\
\hline Warm Season (TS,S) & 91.5 & 92.0 & 90.8 \\
\hline Warm Season (NTS,S) & 99.0 & 91.0 & 90.9 \\
\hline Cool Season (TS, HP) & 96.5 & 97.5 & 99.5 \\
\hline Cool Season (NTS, HP) & 97.5 & 99.0 & 97.4 \\
\hline Cool Season (TS,S) & 98.0 & 92.5 & 96.4 \\
\hline Cool Season (NTS,S) & 97.0 & 99.5 & 98.5 \\
\hline
\end{tabular}


Table 28: CH-3 ground cover by species (2017)

\begin{tabular}{cccc}
\hline & Planted & Not Planted & No Cover \\
\hline DOH Medians (TS, HP) & 76 & 18 & 4 \\
\hline DOH Medians (NTS, HP) & 66 & 27 & 2 \\
\hline DOH Medians (TS,S) & 90 & 7 & 1 \\
\hline DOH Medians (NTS,S) & 75 & 19 & 1 \\
\hline Warm Season (TS, HP) & 81 & 2 & 10 \\
\hline Warm Season (NTS, HP) & 81 & 4 & 9 \\
\hline Warm Season (TS,S) & 79 & 6 & 6 \\
\hline Warm Season $(\mathbf{N T S , S ) ~}$ & 74 & 11 & 9 \\
\hline Cool Season (TS, HP) & 90 & 4 & 1 \\
\hline Cool Season (NTS, HP) & 84 & 8 & 4 \\
\hline Cool Season $($ TS,S) & 89 & 5 & 3 \\
\hline Cool Season $(\mathbf{N T S , S ) ~}$ & 92 & 4 & 2 \\
\hline
\end{tabular}

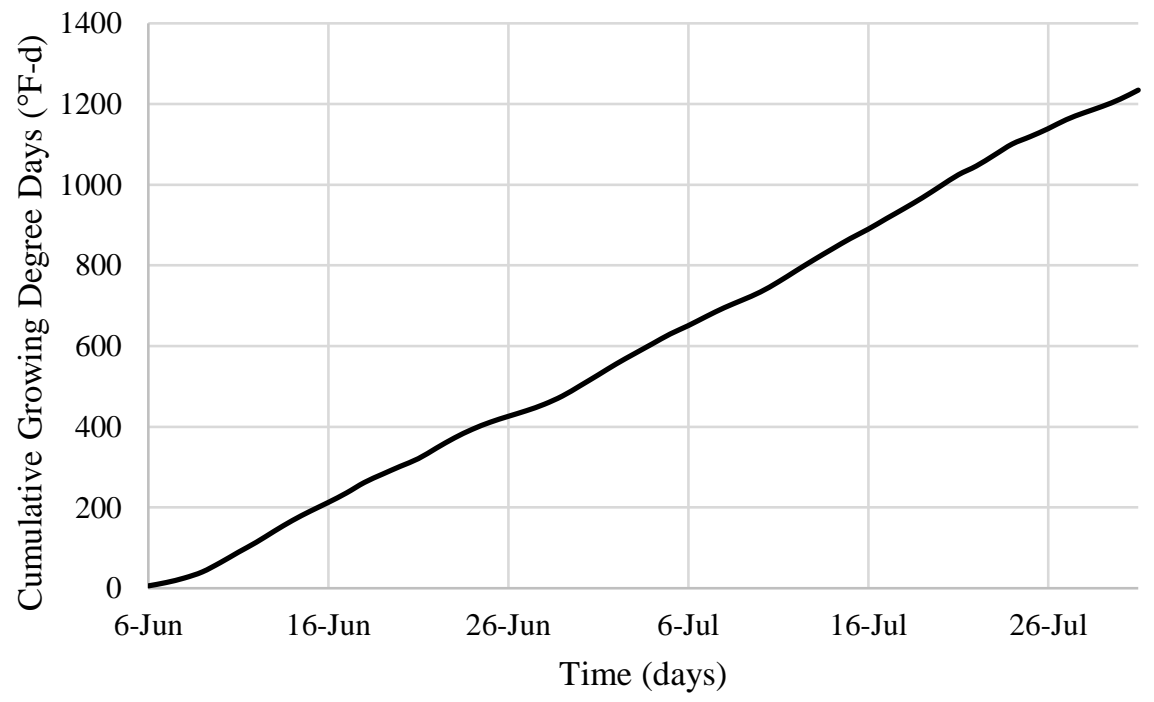

Figure 84: $\mathrm{CH}-3$ cumulative growing degree days (2017) 


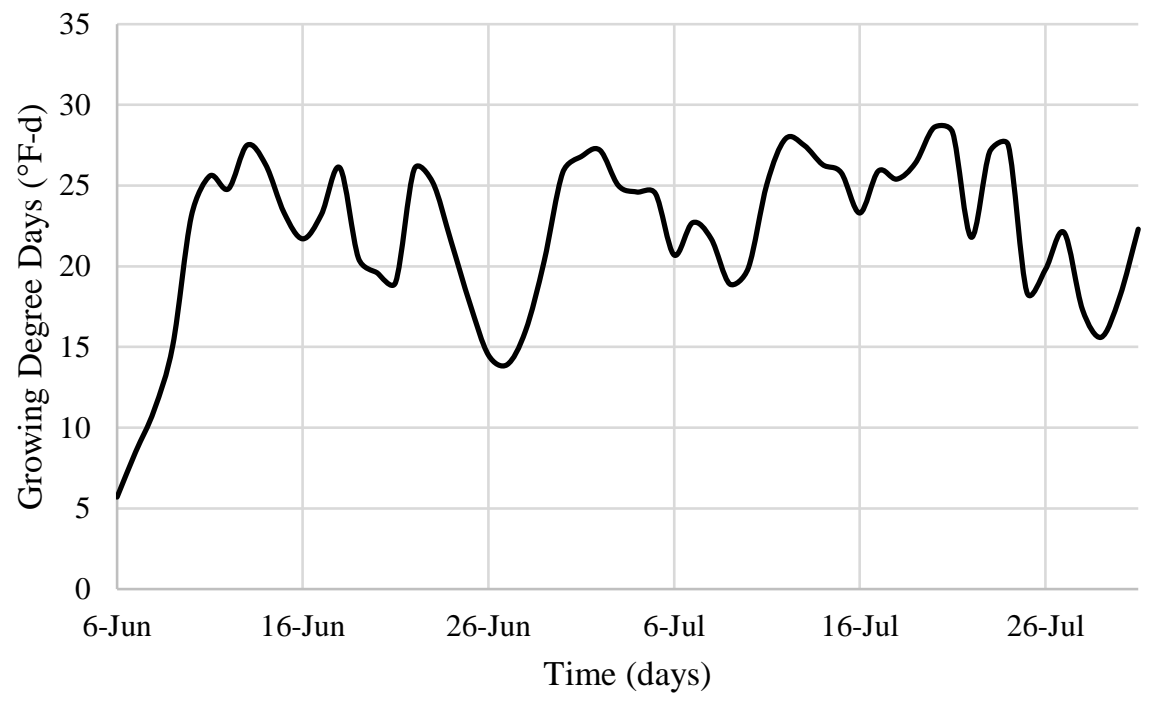

Figure 85: $\mathrm{CH}-3$ daily growing degree days (2017) 
Table 29: CH-3 soil compaction data

\begin{tabular}{|c|c|c|c|c|}
\hline & & \multicolumn{3}{|c|}{ Depth (in) } \\
\hline Date & Treatment & 3 & 6 & 9 \\
\hline \multirow{12}{*}{$6 / 22 / 2016$} & DOH Medians (TS, HP) & 2.5 & $\mathrm{n} / \mathrm{a}$ & $\mathrm{n} / \mathrm{a}$ \\
\hline & DOH Medians (NTS, HP) & 1.0 & $\mathrm{n} / \mathrm{a}$ & $\mathrm{n} / \mathrm{a}$ \\
\hline & DOH Medians $(\mathrm{TS}, \mathrm{S})$ & 2.5 & $\mathrm{n} / \mathrm{a}$ & $\mathrm{n} / \mathrm{a}$ \\
\hline & DOH Medians (NTS,S) & 1.6 & $\mathrm{n} / \mathrm{a}$ & $\mathrm{n} / \mathrm{a}$ \\
\hline & Warm Season (TS, HP) & 2.7 & $\mathrm{n} / \mathrm{a}$ & $\mathrm{n} / \mathrm{a}$ \\
\hline & Warm Season (NTS, HP) & 1.0 & $\mathrm{n} / \mathrm{a}$ & $\mathrm{n} / \mathrm{a}$ \\
\hline & Warm Season (TS,S) & 2.5 & $\mathrm{n} / \mathrm{a}$ & $\mathrm{n} / \mathrm{a}$ \\
\hline & Warm Season (NTS,S) & 1.0 & $\mathrm{n} / \mathrm{a}$ & $\mathrm{n} / \mathrm{a}$ \\
\hline & Cool Season (TS, HP) & 1.6 & $\mathrm{n} / \mathrm{a}$ & $\mathrm{n} / \mathrm{a}$ \\
\hline & Cool Season (NTS, HP) & 1.0 & $\mathrm{n} / \mathrm{a}$ & $\mathrm{n} / \mathrm{a}$ \\
\hline & Cool Season $(\mathrm{TS}, \mathrm{S})$ & 1.0 & $\mathrm{n} / \mathrm{a}$ & $\mathrm{n} / \mathrm{a}$ \\
\hline & Cool Season (NTS,S) & 0.5 & $\mathrm{n} / \mathrm{a}$ & $\mathrm{n} / \mathrm{a}$ \\
\hline \multirow{12}{*}{$10 / 27 / 2016$} & DOH Medians (TS, HP) & 1.9 & $\mathrm{n} / \mathrm{a}$ & $\mathrm{n} / \mathrm{a}$ \\
\hline & DOH Medians (NTS, HP) & 1.5 & $\mathrm{n} / \mathrm{a}$ & $\mathrm{n} / \mathrm{a}$ \\
\hline & DOH Medians (TS,S) & 1.7 & $\mathrm{n} / \mathrm{a}$ & $\mathrm{n} / \mathrm{a}$ \\
\hline & DOH Medians (NTS,S) & 1.4 & $\mathrm{n} / \mathrm{a}$ & $\mathrm{n} / \mathrm{a}$ \\
\hline & Warm Season (TS, HP) & 2.3 & 0.5 & $\mathrm{n} / \mathrm{a}$ \\
\hline & Warm Season (NTS, HP) & 1.4 & $\mathrm{n} / \mathrm{a}$ & $\mathrm{n} / \mathrm{a}$ \\
\hline & Warm Season (TS,S) & 2.3 & $\mathrm{n} / \mathrm{a}$ & $\mathrm{n} / \mathrm{a}$ \\
\hline & Warm Season (NTS,S) & 1.6 & $\mathrm{n} / \mathrm{a}$ & $\mathrm{n} / \mathrm{a}$ \\
\hline & Cool Season (TS, HP) & 1.6 & $\mathrm{n} / \mathrm{a}$ & $\mathrm{n} / \mathrm{a}$ \\
\hline & Cool Season (NTS, HP) & 1.6 & $\mathrm{n} / \mathrm{a}$ & $\mathrm{n} / \mathrm{a}$ \\
\hline & Cool Season (TS,S) & 1.7 & 0.5 & $\mathrm{n} / \mathrm{a}$ \\
\hline & Cool Season (NTS,S) & 1.7 & 0.9 & 0.7 \\
\hline \multirow{12}{*}{ 6/6/2017 } & DOH Medians (TS, HP) & 2.0 & 1.3 & 0.4 \\
\hline & DOH Medians (NTS, HP) & 2.1 & 0.9 & $\mathrm{n} / \mathrm{a}$ \\
\hline & DOH Medians (TS,S) & 2.2 & 1.0 & 0.4 \\
\hline & DOH Medians (NTS,S) & 1.8 & 0.2 & $\mathrm{n} / \mathrm{a}$ \\
\hline & Warm Season (TS, HP) & 2.5 & 0.9 & 0.4 \\
\hline & Warm Season (NTS, HP) & 1.0 & 0.4 & $\mathrm{n} / \mathrm{a}$ \\
\hline & Warm Season (TS,S) & 2.2 & 0.9 & $\mathrm{n} / \mathrm{a}$ \\
\hline & Warm Season $(\mathrm{NTS}, \mathrm{S})$ & 2.0 & 0.8 & $\mathrm{n} / \mathrm{a}$ \\
\hline & Cool Season (TS, HP) & 2.0 & 1.3 & 0.4 \\
\hline & Cool Season (NTS, HP) & 2.3 & 0.5 & $\mathrm{n} / \mathrm{a}$ \\
\hline & Cool Season (TS,S) & 1.9 & 0.8 & $\mathrm{n} / \mathrm{a}$ \\
\hline & Cool Season (NTS,S) & 1.8 & 0.4 & $\mathrm{n} / \mathrm{a}$ \\
\hline
\end{tabular}

Note: $\mathrm{n} / \mathrm{a}$ is used where depths could not be reached by penetrometer due to high compaction 


\subsection{CH-1B Vegetation Data}

Table 30: CH-1B ground cover data (2016)

\begin{tabular}{cccccc}
\hline & $\mathbf{6 / 2 2 / 2 0 1 6}$ & $\mathbf{7 / 2 7 / 2 0 1 6}$ & $\mathbf{8 / 2 5 / 2 0 1 6}$ & $\mathbf{9 / 2 7 / 2 0 1 6}$ & $\mathbf{1 0 / 2 7 / 2 0 1 6}$ \\
\hline Topsoil & 81.3 & 90.3 & 95.0 & 56.7 & 93.0 \\
\hline No Topsoil & 96.7 & 89.3 & 97.0 & 83.7 & 90.7 \\
\hline Biotic Earth & 98.7 & 92.7 & 95.0 & 80.7 & 92.0 \\
\hline ProGanics & 94.7 & 93.7 & 98.3 & 76.7 & 88.0 \\
\hline
\end{tabular}

Table 31: CH-1B ground cover by species (2016)

\begin{tabular}{cccc}
\hline & Planted & Not Planted & No Cover \\
\hline Topsoil & 86 & 7 & 7 \\
\hline No Topsoil & 88 & 3 & 9 \\
\hline ProGanics & 85 & 3 & 12 \\
\hline Biotic Earth Black & 82 & 10 & 8 \\
\hline
\end{tabular}

Table 32: CH-1B ground cover data (2017)

\begin{tabular}{cccc}
\hline & $\mathbf{6 / 6 / 2 0 1 7}$ & $\mathbf{7 / 1 0 / 2 0 1 7}$ & $\mathbf{8 / 1 / 2 0 1 7}$ \\
\hline Topsoil & 89.7 & 92.0 & 80.9 \\
\hline No Topsoil & 83.3 & 92.7 & 85.0 \\
\hline Biotic Earth & 92.7 & 93.0 & 85.5 \\
\hline ProGanics & 91.7 & 90.0 & 82.7 \\
\hline
\end{tabular}

Table 33: CH-1B ground cover by species (2017)

\begin{tabular}{lccc}
\hline & Planted & Not Planted & No Cover \\
\hline Topsoil & 39 & 34 & 17 \\
\hline No Topsoil & 63 & 15 & 14 \\
\hline ProGanics & 48 & 30 & 16 \\
\hline Biotic Earth Black & 57 & 22 & 13 \\
\hline
\end{tabular}




\subsection{CH-1B Soil Data}

Table 34: CH-1B soil compaction data

\begin{tabular}{ccccccc}
\hline & & \multicolumn{5}{c}{ Depth (in) } \\
\hline Date & Treatment & $\mathbf{3}$ & $\mathbf{6}$ & $\mathbf{9}$ & $\mathbf{1 2}$ & $\mathbf{1 5}$ \\
\hline \multirow{3}{*}{ 6/22/2016 } & Topsoil & 2.8 & 2.4 & n/a & n/a & n/a \\
\cline { 2 - 7 } & No Topsoil & 1.8 & 0.8 & n/a & n/a & n/a \\
\cline { 2 - 7 } & Biotic Earth & 1.4 & n/a & n/a & n/a & n/a \\
\cline { 2 - 7 } & ProGanics & 2.1 & 0.4 & n/a & n/a & n/a \\
\hline \multirow{4}{*}{ 10/27/2016 } & Topsoil & 1.9 & 1.3 & 0.5 & n/a & n/a \\
\cline { 2 - 7 } & No Topsoil & 0.9 & n/a & n/a & n/a & n/a \\
\cline { 2 - 7 } & Biotic Earth & 0.6 & n/a & n/a & n/a & n/a \\
\cline { 2 - 7 } & ProGanics & 1.7 & 0.5 & n/a & n/a & n/a \\
\hline & Topsoil & 2.5 & 1.6 & 0.8 & 0.5 & 0.3 \\
\cline { 2 - 7 } & No Topsoil & 1.3 & 0.5 & n/a & n/a & n/a \\
\cline { 2 - 6 } & Biotic Earth & 1.2 & 0.3 & n/a & n/a & n/a \\
\cline { 2 - 6 } & ProGanics & 1.7 & 0.6 & n/a & n/a & n/a \\
\hline
\end{tabular}

Note: $\mathrm{n} / \mathrm{a}$ is used where depths could not be reached by penetrometer due to high compaction 